\title{
MAXIMUM KNOWN STAGES AND DISCHARGES OF NEW YORK STREAMS, 1865-1989, WITH DESCRIPTIONS OF FIVE SELECTED FLOODS, 1913-85
}

By Richard Lumia and Patricia M. Murray

\section{U.S. GEOLOGICAL SURVEY}

Water-Resources Investigations Report 92-4042

Prepared in cooperation with the NEW YORK STATE DEPARTMENT OF TRANSPORTATION 


\title{
U.S. DEPARTMENT OF THE INTERIOR
}

\author{
BRUCE BABBITT, Secretary
}

\section{U.S. GEOLOGICAL SURVEY}

\author{
Dallas L. Peck, Director
}

For additional information write to:

U.S. Geological Survey

P.O. Box 1669

Albany, NY 12201
Copies of this report may be purchased from:

U.S. Geological Survey

Open-File Reports-ESIC

Box 25425

Denver, CO 80225 


\section{CONTENTS}

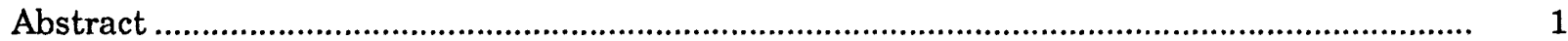

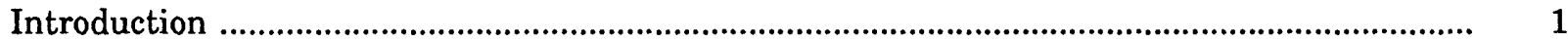

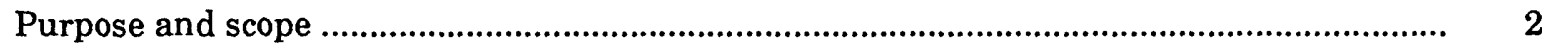

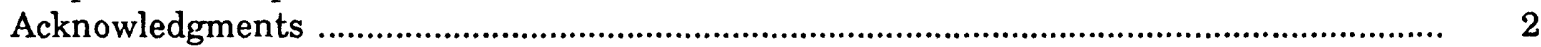

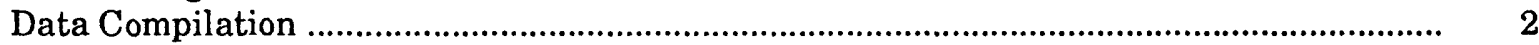

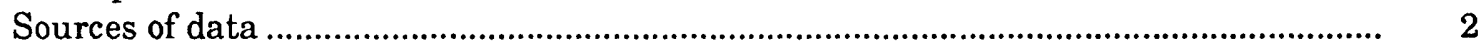

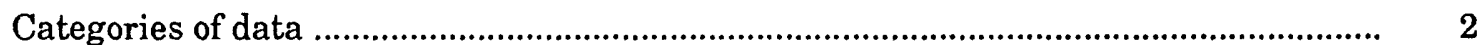

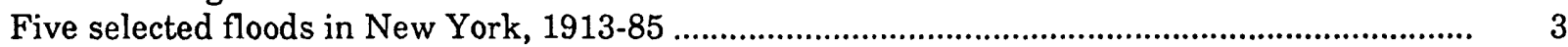

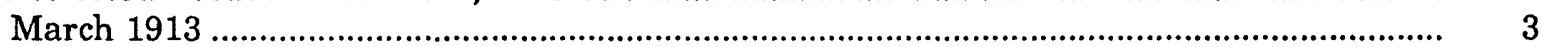

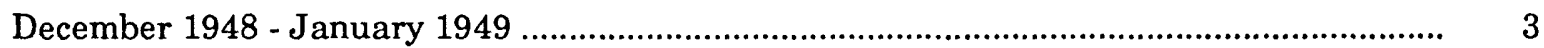

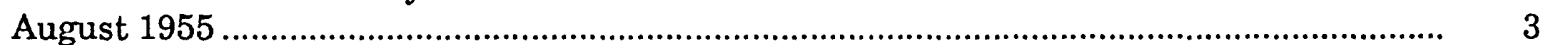

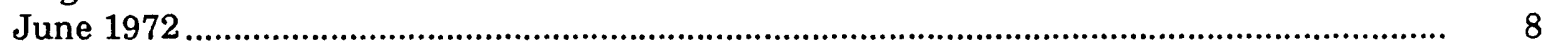

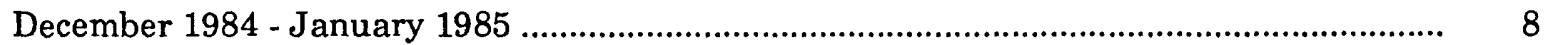

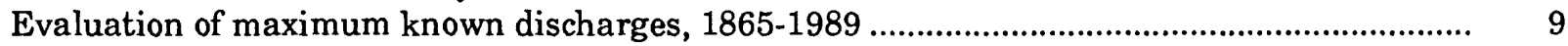

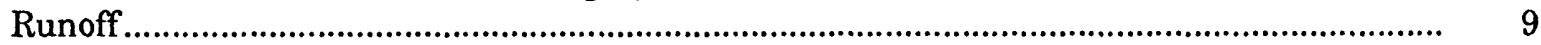

Envelope curves of maximum known discharges ............................................................ 9

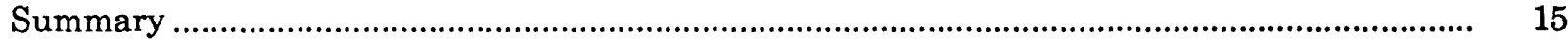

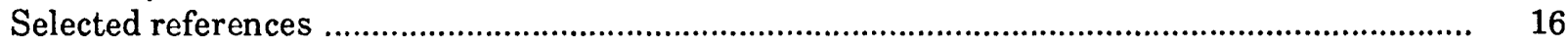

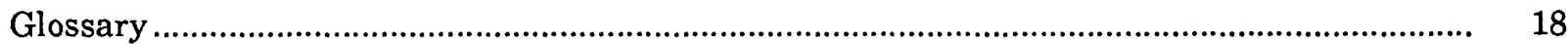

\section{ILLUSTRATIONS}

(Plates are in pocket)

Plates 1-2. Maps of New York showing locations of hydrologic regions and:

1. Streamflow-gaging stations used in the study

2. Miscellaneous-measurement sites used in the study

Figure 1-2. Maps of New York showing:

1. Locations of counties and major drainage basins

2. Flood boundaries for five selected storms, 1913-85 .......................................... 6

3-8. Graphs showing:

3. Years of documented maximum known floods in relation to number of gaging stations and miscellaneous-measurement sites

4. Maximum known runoff for nine hydrologic regions of New York ................... $\quad 10$

5. Maximum known runoff in New York in relation to drainage area .................. $\quad 10$

6. Maximum known discharges in New York and the United States in relation to drainage area

7. Maximum known discharges in nine hydrologic regions of New York in relation to drainage area

8. Envelope curves for nine hydrologic regions of New York 


\section{TABLES}

Table 1. Summary of major floods in New York, 1865-1989

2. Maximum known stages and discharges of New York streams through September 1989

3. Alphabetical listing of stations shown in table 2, with location data

\section{CONVERSION FACTORS AND VERTICAL DATUM}

\begin{tabular}{|c|c|c|}
\hline Multiply & By & To Obtain \\
\hline \multicolumn{3}{|c|}{ Length } \\
\hline inch (in) & 25.40 & millimeter \\
\hline foot $(\mathrm{ft})$ & 0.3048 & meter \\
\hline \multirow[t]{2}{*}{ mile $(\mathrm{mi})$} & 1.609 & kilometer \\
\hline & Area & \\
\hline \multirow[t]{2}{*}{ square mile $\left(\mathrm{mi}^{2}\right)$} & 2.590 & square kilometer \\
\hline & Volume & \\
\hline \multirow[t]{2}{*}{ cubic foot $\left(\mathrm{ft}^{3}\right)$} & 0.02832 & cubic meter \\
\hline & Flow & \\
\hline \multirow{2}{*}{$\begin{array}{l}\text { cubic foot per second }\left(\mathrm{ft}^{3} / \mathrm{s}\right) \\
\text { cubic foot per second per } \\
\text { square mile }\left[\left(\mathrm{ft}^{3} / \mathrm{s}\right) / \mathrm{mi}^{2}\right]\end{array}$} & 0.02832 & cubic meter per second \\
\hline & 0.01093 & $\begin{array}{c}\text { cubic meter per second } \\
\text { per square kilometer }\end{array}$ \\
\hline \multicolumn{3}{|c|}{$\begin{array}{l}\text { Sea Level: In this report, "sea level" refers to the National Geodetic Vertical } \\
\text { Datum of } 1929 \text {-a geodetic datum derived from a general adjust- } \\
\text { ment of the first-order level nets of the United States and Canada, } \\
\text { formerly called Sea Level Datum of } 1929 .\end{array}$} \\
\hline
\end{tabular}




\title{
MAXIMUM KNOWN STAGES AND DISCHARGES OF NEW YORK STREAMS, 1865-1989, WITH DESCRIPTIONS OF FIVE SELECTED FLOODS, 1913-85
}

\author{
By Richard Lumia and Patricia M. Murray
}

\begin{abstract}
Maximum known stages and discharges at 1,280 sites on 863 New York streams from 1865 through September 1989 are tabulated. Discharges are given in cubic feet per second and in cubic feet per second per square mile. The drainage areas range from 0.03 to 298,800 square miles $\left(\mathrm{mi}^{2}\right)$; the maximum drainage area is $8,288 \mathrm{mi}^{2}$ (Hudson River at Albany) if the three sites with larger drainage areas on the St. Lawrence and Niagara Rivers, which drain the Great Lakes, are excluded. Most data were obtained from earlier U.S. Geological Survey compilations and records, but some were provided by State, local, and other Federal agencies, and private organizations.

The information is listed in two tables; one is grouped by major drainage basins and U.S. Geological Survey station number, in downstream order, and the other by stream name, in alphabetical order. The first table gives the drainage area, period of record, and stage and discharge data for each site; the second gives the location, by latitude and longitude, major basin, stream to which the site is tributary, number of miles above the mouth, topographic quadrangle, and hydrologic region. A description of five selected floods during 1913-85 is included.

Curves that "envelop" maximum discharges were developed for each of nine hydrologic regions from a plot of maximum known discharge in relation to drainage area; these curves are compared with a curve derived from a plot of maximum known discharges throughout the United States. Discharges represented by the national curve range from 2.8 to 5.2 times greater than those represented by the New York curve for drainage areas of 1.0 and $1,000 \mathrm{mi}^{2}$, respectively. The relative magnitudes of discharges in nine hydrologic regions of New York, as shown in graphs that relate maximum known discharge to drainage area, indicate that the largest known discharges per square mile are in western New York and the Catskill Mountain area, and the smallest are on Long Island.
\end{abstract}

\section{INTRODUCTION}

Information on the stages and discharges of streams during flooding is useful to designers of bridges, culverts, and dams and to flood-plain managers. For nearly a century, the U.S. Geological Survey (USGS) has been collecting peak-stage and discharge data at continuous-record gaging stations, partial-record stations, and at miscellaneous-measurement sites (see glossary) during and(or) after significant floods. Most of the data are accessible through the USGS WATSTORE (National Water Data Storage and Retrieval System) peak-flow computer file in Reston, Va., and in USGS annual data reports that list each State's peak stage and discharge data (U.S. Geological Survey, 1960-90). Data from a few sites near the New York border in adjacent States are included in this report.

In 1984, the USGS, in cooperation with the New York State Department of Transportation, began a study to compile the maximum known stages and discharges of New York streams through September 1989 to supplement a similar report through September 1983 (Robideau and others, 1984). Several USGS reports have documented maximum stages and discharges of $\mathrm{New}$ York streams (Dougherty, 1960; Dunn, 1970; Leonard and Dunn, 1976; and Robideau and others, 1984); this volume includes data on significant floods that have occurred since then. These data supersede those given in earlier reports. 


\section{Purpose and Scope}

This report is a compilation of all maximum stages and discharges of New York streams on record at the USGS and includes some data furnished by State and local agencies and other Federal and private organizations. Data from 1,280 sites on 863 streams were compiled. The report (1) lists the sources and categories of data, (2) briefly describes the location and peak discharges of the five most severe floods in New York during 1913-85, (3) summarizes the maximum discharges of 1865-1989 in a series of graphs, box plots, and envelope curves, (4) presents the maximum stage and discharge of each site during 1865-1989 in downstream order by river basin (table 2), and (5) lists the stations from table 2 in alphabetical order and includes several categories of information on the location of each site (table 3). It also includes a glossary of technical terms used in the text and tables, and two oversize maps showing site locations and hydrologic-region boundaries.

\section{Acknowledgments}

The New York State Department of Environmental Conservation, the U.S. Army Corps of Engineers, the Hudson River-Black River Regulating District, the New York Power Authority, Niagara Mohawk Power Corporation, New York City Department of Environmental Protection, Cornell University, and several other municipal and county governments provided support for data-collection programs.

\section{Data Compllation}

Several sources of data and categories of peak-stage and discharge data were researched and documented, as described in the following paragraphs.

\section{Sources of Data}

Most of the peak-stage and discharge data in this report were obtained through the Geological Survey's WATSTORE peak-flow file in Reston, Va., and from a miscellaneous peak-flow-measurement file in the USGS office in Albany, N.Y. Most miscellaneous-discharge measurements were made by indirect methods (slope-area, contractedopening, and so forth; see glossary for definitions). Information from several previous USGS publications was used to supplement the peak-flow and miscellaneous-measurement data.

Other sources of peak-stage and discharge information were local organizations and Federal or State agencies such as the U.S. Army Corps of Engineers, the National Weather Service, and the New York State Department of Transportation.

\section{Categories of Data}

The categories of data are grouped according to the type of peak stage and(or) discharge measurement site: (1) continuous-record gaging stations, (2) partial-record gaging stations, and (3) miscellaneous-measurement sites. A definition of each is given in the glossary. Continuousrecord and partial-record gaging stations are sites established by the Geological Survey for specific hydrologic and(or) hydraulic studies, and their data are published in the resulting interpretive reports. Locations of the 726 continuousand partial-record streamflow gaging stations are shown on plate 1. The peak discharges at these sites represent periods of record ranging from a few years to several decades. Miscellaneous-measurement sites are mostly sites where the Survey has made a discharge measurement by indirect methods (slope-area, contractedopening, flow-over-dam, or flow-through-culvert; see glossary for definitions). Locations of the 554 miscellaneous-measurement sites are shown in plate 2. The miscellaneous-site category also includes stream sites at which State, local, and other Federal agencies and private organizations have determined a peak stage or discharge and published the values. 


\section{FIVE SELECTED FLOODS IN NEW YORK, 1913-85}

The most significant floods in New York's history are listed chronologically in table 1; counties and major drainage basins are shown in figure 1 (p. 5), and geographic features and community names are shown on plates 1 and 2 . Flood severity was evaluated in terms of magnitude, extent, loss of life, and property damage. Data from about 250 streamflow-gaging stations were used to estimate the extent and magnitude of the five most severe floods of this century; most streams in the State were ungaged before that time. Of these five floods, three (1913, 1948 , and 1984) were caused by winter storms, and two (1955 and 1972) by summer storms (hurricanes). Flood boundaries during these storms are delineated in figure 2 (p. 6). Floodrecurrence intervals (defined in glossary) used in this report were determined according to guidelines recommended by U.S. Water Resources Council (1981).

The number of gaging stations and miscellaneous-measurement sites at which the maximum known discharge occurred during a particular calendar year are shown in figure 3 (p. 7), which represents only years with at least 10 entries in table 2. Figure 3 indicates that the year in which the largest number of maximum known discharges were documented (132 stations and sites) was 1972 (hurricane Agnes flood of June 1972).

\section{March 1913}

The flood of March 27-28, 1913, was caused by excessive rainfall, snowmelt, and probably frozen ground in northern New York. During March 25-27, some areas of northern New York experienced sleet that felled branches and utility wires (Cox, 1913). A previous storm of moderate intensity on March 22-23 had left much of the State with saturated ground. By March 27, the storm had stalled and was aligned from New York to North Carolina. Total precipitation in most of north-central New York during March 1913 was 6 to 8 in. above normal (Gravlee and others, 1991). In western New York, the storm of March 27-28 produced an average of $4.4 \mathrm{in}$. of rainfall over the entire Genesee River basin.

Much of north-central New York, including the entire Mohawk and upper Hudson River basins, was flooded as a result of the March storms (fig. 2). The Sacandaga River near Hope reached its maximum discharge of record, 32,000 $\mathrm{ft}^{3} / \mathrm{s}$, which has a recurrence interval greater than 100 years. (Flood-recurrence interval is defined in glossary.) Peak discharges on the Mohawk River at Little Falls $\left(32,400 \mathrm{ft}^{3} / \mathrm{s}\right)$ and on the Hudson River at Mechanicville $(120,000$ $\mathrm{ft}^{3} / \mathrm{s}$ ) were also record maximums, and their recurrence intervals also were greater than 100 years. The water level at Indian Lake was $5.4 \mathrm{ft}$ above the crest of the spillway on March 28, 1913. This is the maximum stage known to date. The peak flow in downstream reaches of the Genesee River at Rochester was $42,000 \mathrm{ft}^{3} / \mathrm{s}$ (recurrence interval of 75 years) and resulted in extensive flooding.

Several bridges and highways were damaged or destroyed by the flood. The devastation prompted enactment of several flood-control measures throughout the damaged areas.

\section{December 1948 - January 1949}

Rainfall ranging from 5 to 12 in. fell on a 4,500- $\mathrm{mi}^{2}$ area in eastern New York and southwestern New England from December 29, 1948, to January 1, 1949. A frontal system stalled over the mid-Atlantic coast on December 30 , and rainfall intensified. A 1-day rainfall of 5.5 in. was recorded at Cherryplain on December 31. Snowmelt was a minor contributing factor, and the effect of frozen ground on runoff was confined to the beginning of the flood (U.S. Geological Survey, 1952).

Record peak discharges were recorded at several gaging stations in the Hudson River basin, including those on the Hudson River at Newcomb, North Creek, and Hadley; on the Hoosic River at Eagle Bridge; and on Kinderhook Creek at Rossman. Each of these peak flows had a recurrence interval that exceeded 75 years. The peak discharge on the Hoosic River at Eagle Bridge $\left(55,400 \mathrm{ft}^{3} / \mathrm{s}\right)$ had a recurrence interval greater than 100 years. The peak discharge on the Hudson River at Green Island was 181,000 $\mathrm{ft} 3 / \mathrm{s}$, which had a recurrence interval of about 75 years. The peak discharge of $31,400 \mathrm{ft}^{3} / \mathrm{s}$ on the Sacandaga River near Hope had a recurrence interval of slightly less than 100 years. 


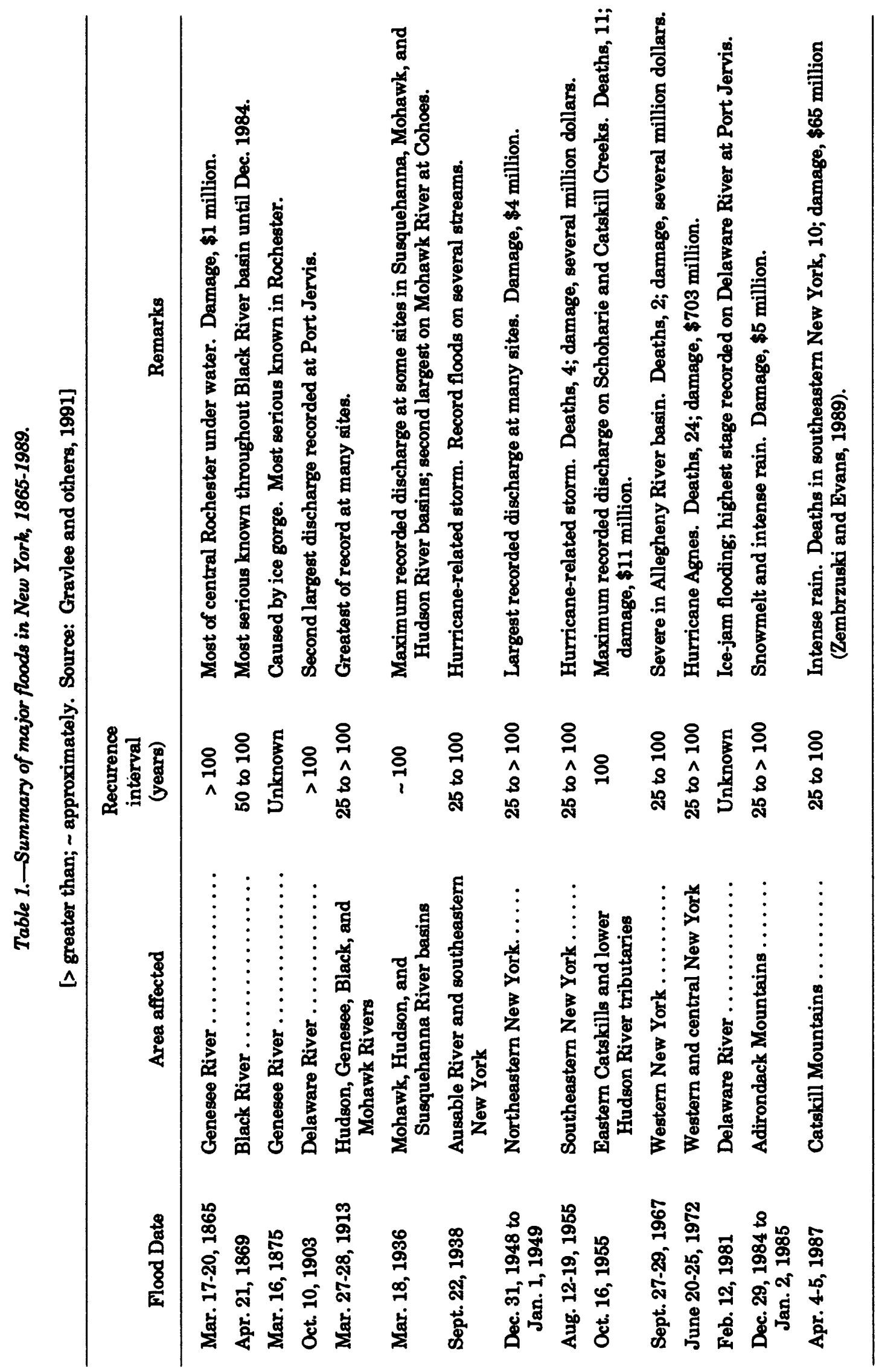




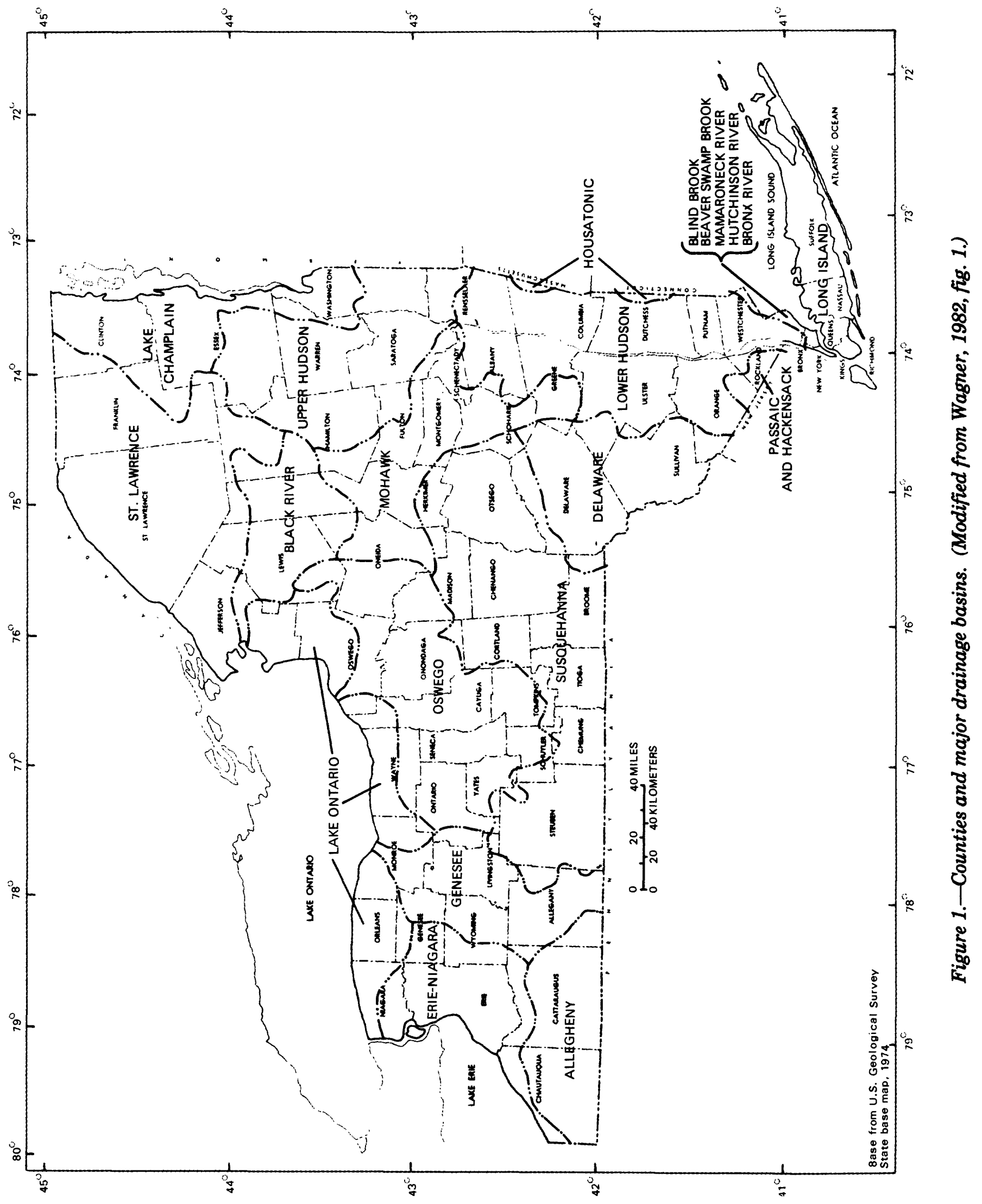



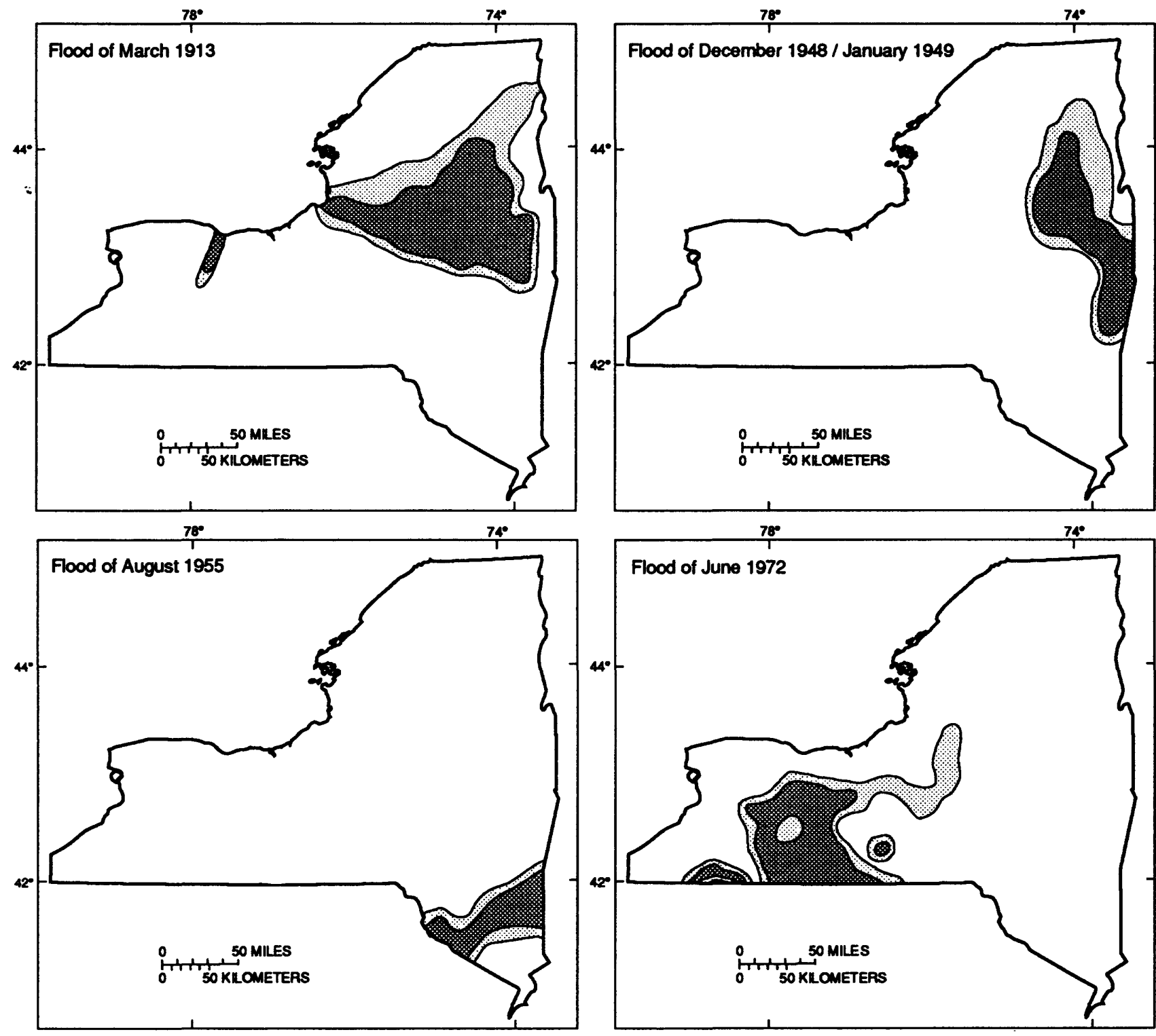

EXPLANATION

FLOOD-RECURRENCE INTERVAL

Greater than 50 years

25 to 50 years

Less than 25 years

Figure 2.-Flood-boundaries for five selected storms, 1913-85. (From Gravlee and others, 1991.)

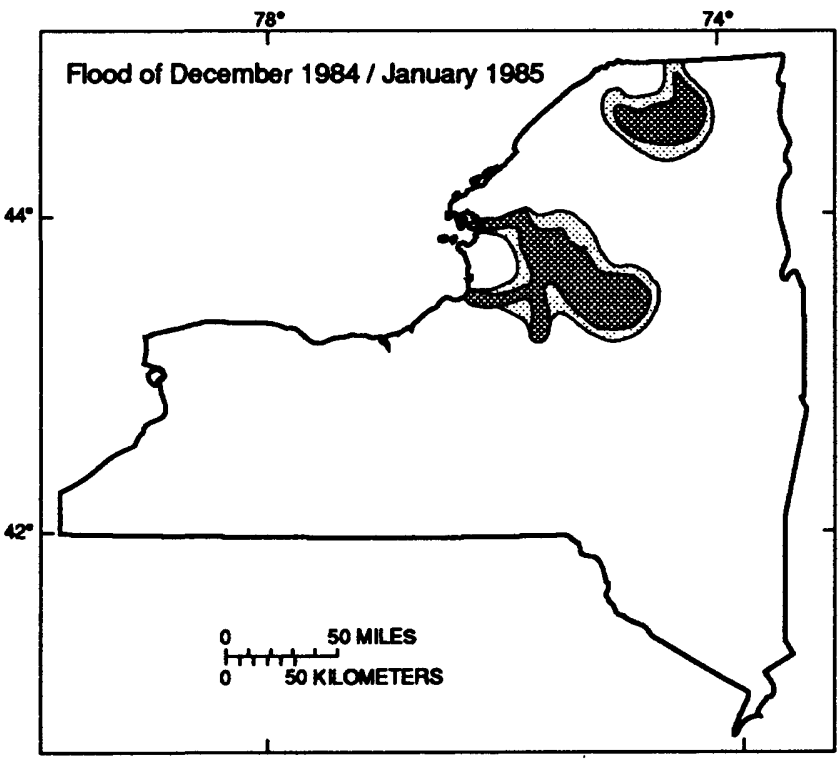




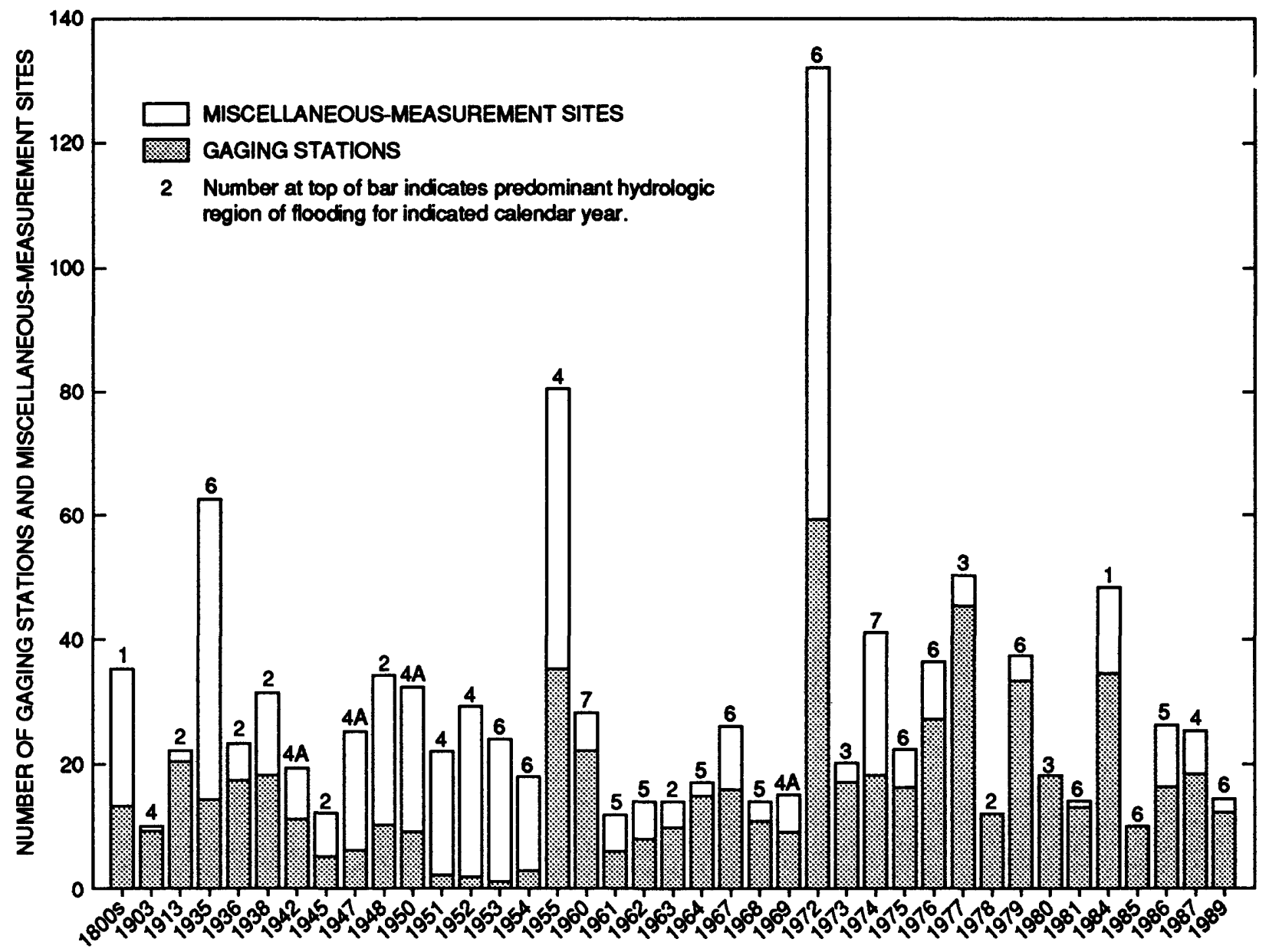

CALENDAR YEAR WITH 10 OR MORE ENTRIES IN TABLE 2

Figure 3.-Years of documented maximum known floods in relation to number of gaging stations and miscellaneous-measurement sites. (Locations of hydrologic regions are shown on pls. 1 and 2.)

In eastern New York, damage from the flood of December 31, 1948 to January 1, 1949 was most extensive ( $\$ 2$ million) in the Hoosic River basin (U.S. Geological Survey, 1952). Total damage in eastern New York was \$4 million (U.S. Geological Survey, 1952).

\section{August 1955}

During August 12-19, 1955, intense rainfall from two hurricanes that dissipated over southeastern New York and southern New England caused severe flooding. Slide Mountain, in the Catskill Mountains, received the largest total rainfall for the month (21.0 in.), of which 18.3 in. was received during August 11-15 and 18-19 (U.S. Weather Bureau, 1955). The remnants of Hurricane Connie caused considerable flooding and damage throughout New York City, Long
Island, and the Catskill Mountains during August 12-13. Several sites in these areas received 1-day rainfalls of as much as $8.2 \mathrm{in}$. on August 12 or 13 (U.S. Weather Bureau, 1955).

During August 18-19, 1955, intense rains over southeastern New York accompanying Hurricane Diane produced unprecedented flooding in several streams. One-day rainfalls of nearly 7 in. were recorded at several sites throughout southeastern New York (U.S. Weather Bureau, 1955), and much of the Wallkill River valley was flooded for 24 hours or longer. Hardest hit were the communities of Copake, Ellenville, Wurtsboro, and Port Jervis, where the Delaware River peaked at a record $233,000 \mathrm{ft}^{3} / \mathrm{s}$. The rain band from Hurricane Diane was nearly parallel to the Delaware River. Several gaging stations on the main stem and tributaries of the Delaware River and on tribu- 
taries of the lower Hudson River recorded peak discharges having recurrence intervals of greater than 50 years, and some of greater than 100 years.

Four deaths were reported as a result of the August 12-19, 1955, floods. People were evacuated and highways closed. State offreials estimated damage at several million dollars (Bogart, 1960), of which about one-third was to public property, mostly roads and bridges. The remaining damage was to private property and crops.

\section{June 1972}

Record-breaking floods throughout much of western and central New York occurred during June $20-25,1972$, as a result of torrential rains associated with remnants of Hurricane Agnes. During the waning stages, the hurricane merged with a low-pressure system that had been stationary for more than 24 hours over the northeastern United States and produced as much as 16 in. of rain in western and central New York (Bailey and others, 1975).

Flooding was particularly extensive and devastating within the Chemung, Genesee, and Allegheny River basins. In the Chemung River basin and along the Susquehanna River, from just upstream from the New York-Pennsylvania State line to Chesapeake Bay in Maryland, flooding was the greatest known since 1784 (Bailey and others, 1975). Peak discharges having recurrence intervals of greater than 100 years were recorded at most gaging stations in the Chemung River basin. The peak discharge of $189,000 \mathrm{ft}^{3} / \mathrm{s}$ recorded on the Chemung River at Chemung, where records date back to 1904, was about 1.5 times that of the previous maximum in 1946. The peak stage was about $8 \mathrm{ft}$ higher than the previous known maximum. The peak discharge of $73,000 \mathrm{ft}^{3} / \mathrm{s}$ (recurrence interval greater than 100 years) recorded on the Allegheny River at Salamanca was also about 1.5 times the previous maximum, which occurred in 1956.

Flooding in the Genesee River basin upstream from Mount Morris Lake was extreme, and most peak flows had recurrence intervals of greater than 100 years. Storage of floodwaters in Mount Morris Lake during June 20-25 (about 315,000 acre-ft with a lake-level rise of more than $152 \mathrm{ft}$ ) prevented disastrous flooding along downstream reaches of the Genesee River (Bailey and others, 1975). Other areas of major flooding were along streams upstream from
Cayuga Lake near Ithaca and along outlets of several of the smaller Finger Lakes, such as Owasco Lake outlet near Auburn, where the peak flow was the largest since 1913. Runoff from the storm kept the storage in the Finger Lakes greater than normal from mid-June through the end of July. During June, 24 gaging stations in western New York that had 20 years of record or more recorded peak discharges that exceeded any known previously.

Hurricane Agnes was the costliest in United States history, and New York was second only to Pennsylvania in the number of deaths and amount of damage. About 100,000 people were evacuated from their homes. The flooding caused 24 deaths and damage of $\$ 703$ million, of which about $\$ 157$ million was in the Susquehanna River basin in western and central New York (Bailey and others, 1975). Twelve counties in western New York were declared disaster areas.

\section{December 1984 - January 1985}

Precipitation from a strong warm front during December 28-30, 1984 (water year 1985), combined with unseasonably warm temperatures and rapidly melting snow, caused extensive flooding from December 29, 1984 to January 2, 1985, throughout northern New York. The maximum rainfall recorded during December 2830 was 6.4 in. at Stillwater Reservoir. An additional 1 to 2 in. of rain fell in much of northern New York during a second storm on January 1-2, 1985. Factors that contributed to the large runoff were frozen ground in the Adirondack Mountains, an abnormally wet November and early December, and a thick snow cover before the storm (Lumia and others, 1987).

Flooding was most extensive along the Black and Salmon Rivers, which flow into Lake Ontario. Computed maximum discharges at 12 sites within these basins had recurrence intervals of 100 years or greater, as did five other sites on streams in northern New York. The nature of the storm and the antecedent conditions caused floods with large recurrence intervals to occur on large streams and little or no flooding on small streams. The peak discharge recorded on the Black River at Watertown was $42,900 \mathrm{ft}^{3} / \mathrm{s}$ (100-year recurrence interval), which is the maximum discharge known since 1869. The map in figure 2 shows that the most significant flooding was southwest and north of the Adirondack Mountains. 
Reservoirs and lakes throughout northern New York had a moderating effect on flooding from the storm. Large quantities of storm runoff were contained, particularly in the Mohawk and Black River basins, where Hinckley and Stillwater Reservoirs stored 3.4 and 5.0 in. of storm runoff, respectively.
The flood of December 29, 1984 to January 2, 1985 forced the evacuation of 2,000 residents but caused no loss of life. Flood damage to property, roads, and bridges was about $\$ 5$ million (Lumia and others, 1987). Eight counties were declared disaster areas by the Governor of New York, and two counties were declared Federal disaster areas.

\section{EVALUATION OF MAXIMUM KNOWN DISCHARGES, 1865-1989}

Several types of graphs were constructed to summarize and evaluate the data from table 2 and to compare maximum known discharges among the nine hydrologic regions of New York. Plates 1 and 2 show hydrologic regions as delineated by Lumia (1991) for a statewide floodfrequency analysis. Long Island was not included in that study but is included here as a ninth hydrologic region, labeled LI.

\section{Runoff}

Maximum known runoffs, in cubic feet per second per square mile $\left[\left(\mathrm{ft}^{3} / \mathrm{s}\right) / \mathrm{mi}^{2}\right]$, for each hydrologic region are compared in box plots in figure 4. The highest median values are in regions 4 and $4 \mathrm{~A}$ (Catskill Mountains), and the lowest are on Long Island.

Peak runoff values for each of the 1,280 sites on 863 streams are plotted against drainage area in figure 5, which indicates generally greater runoff at sites with small drainage areas than at those with large drainage areas. The wide scatter of runoff values among similar-sized drainage areas is discussed in the next section. Documented peak runoff values for New York range from 1.1 to $4,742\left(\mathrm{ft}^{3} / \mathrm{s}\right) / \mathrm{mi}^{2}$. This range excludes station 04232043 near Rochester, which recorded a runoff greater than $10,000\left(\mathrm{ft}^{3} / \mathrm{s}\right) / \mathrm{mi}^{2}$ that resulted from a break in the New York State Barge Canal. This site is also excluded from all graphs in this report.

\section{Envelope Curves of Maximum Known Discharges}

The magnitude of maximum known discharges for a region in relation to drainage area can be represented by "envelope curves," which indicate the greatest values of discharge for the range of drainage areas at sites in the region.
Envelope curves were developed for each of the nine hydrologic regions of the State and for the entire state.

The upper envelope curve in figure 6 represents maximum known discharges in the United States in relation to drainage area as plotted by Crippen and Bue (1977), and the lower curve represents the 1,280 data points for New York (from table 2). The position of the New York curve in relation to the national curve suggests that the maximum flood-discharge potential (per square mile) of New York streams is less than that of streams in several other parts of the United States. Rainfall-intensity maps and a regional analysis of maximum known discharges in the United States by Crippen and Bue (1977) support this conclusion. Discharges represented by the national curve range from 2.8 to 5.2 times greater than those represented by the New York curve for drainage areas of 1.0 and $1,000 \mathrm{mi}^{2}$, respectively.

The wide scatter of points in figures 5 and 6 could result from differences in (1) periods of record, (2) magnitudes and types of basin characteristics that affect hydrologic response at a specific site, (3) degrees and periods of regulation, (4) detail and extent of documentation of notable floods in an affected area, and (5) measurement errors. To evaluate the 1,280 sites, a regional analysis, based on eight hydrologic regions developed by Lumia (1991) for a statewide flood-frequency analysis, was made. (Long Island was excluded from that study but is indicated here as a ninth hydrologic region. Locations of the nine regions are shown in pls. 1 and 2.)

Maximum known discharges (from table 2) for each of the nine hydrologic regions are plotted against drainage area in figure 7; also plotted are computed 100-year discharges (Lumia, 1991) for unregulated sites with at least 


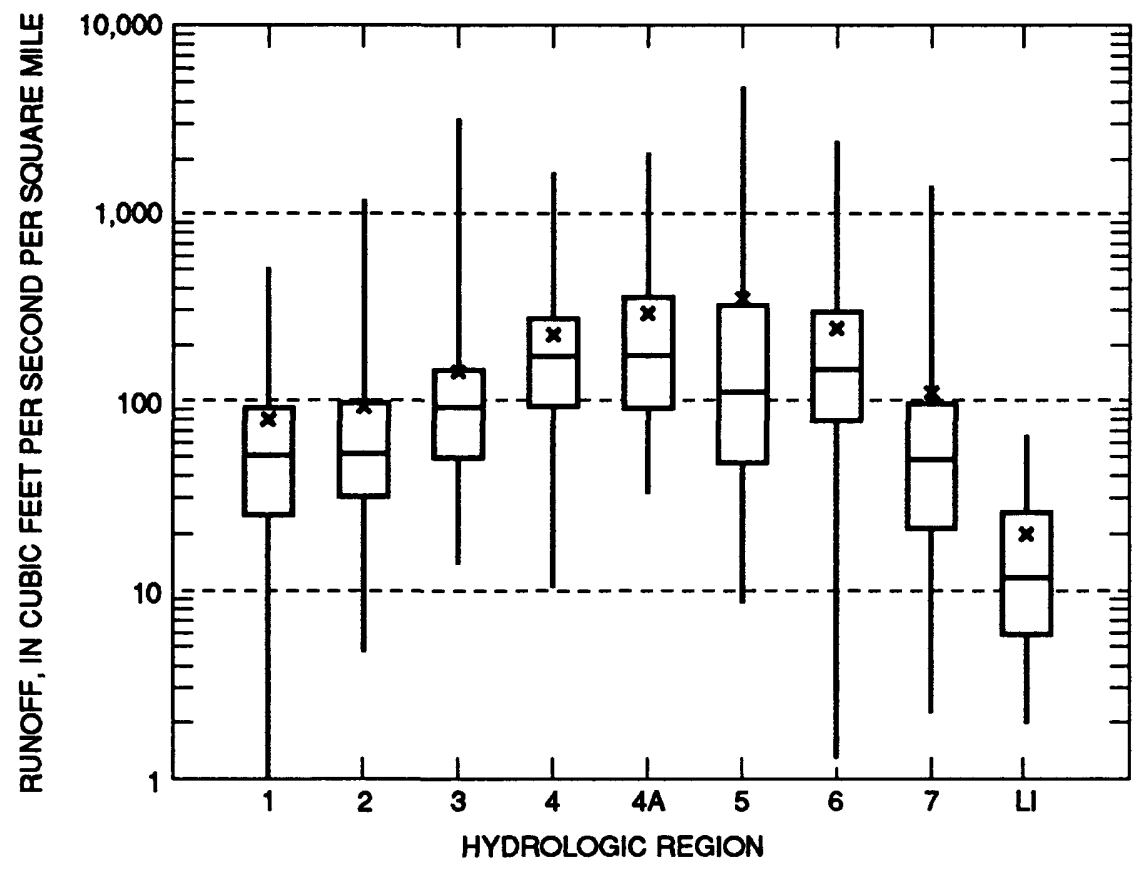

EXPLANATION
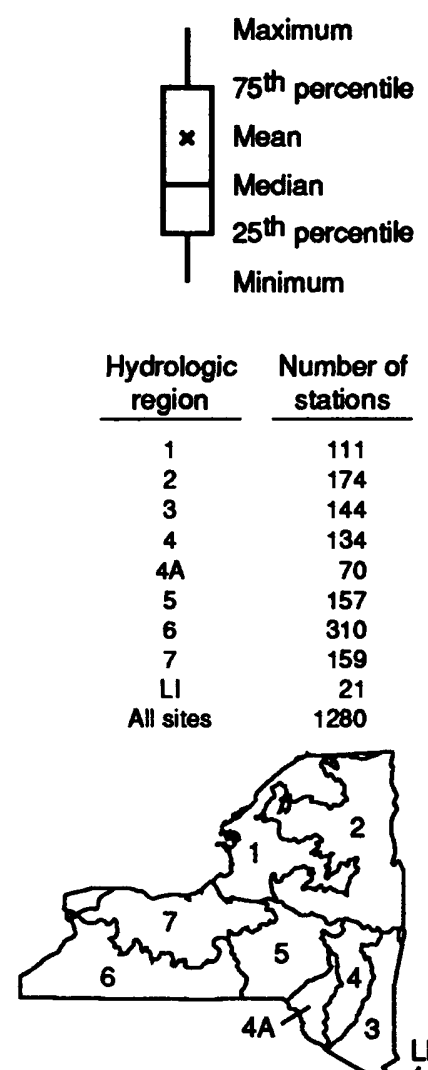

HYDROLOGIC REGIONS

Figure 4.-Maximum known runoff for nine hydrologic regions of New York.

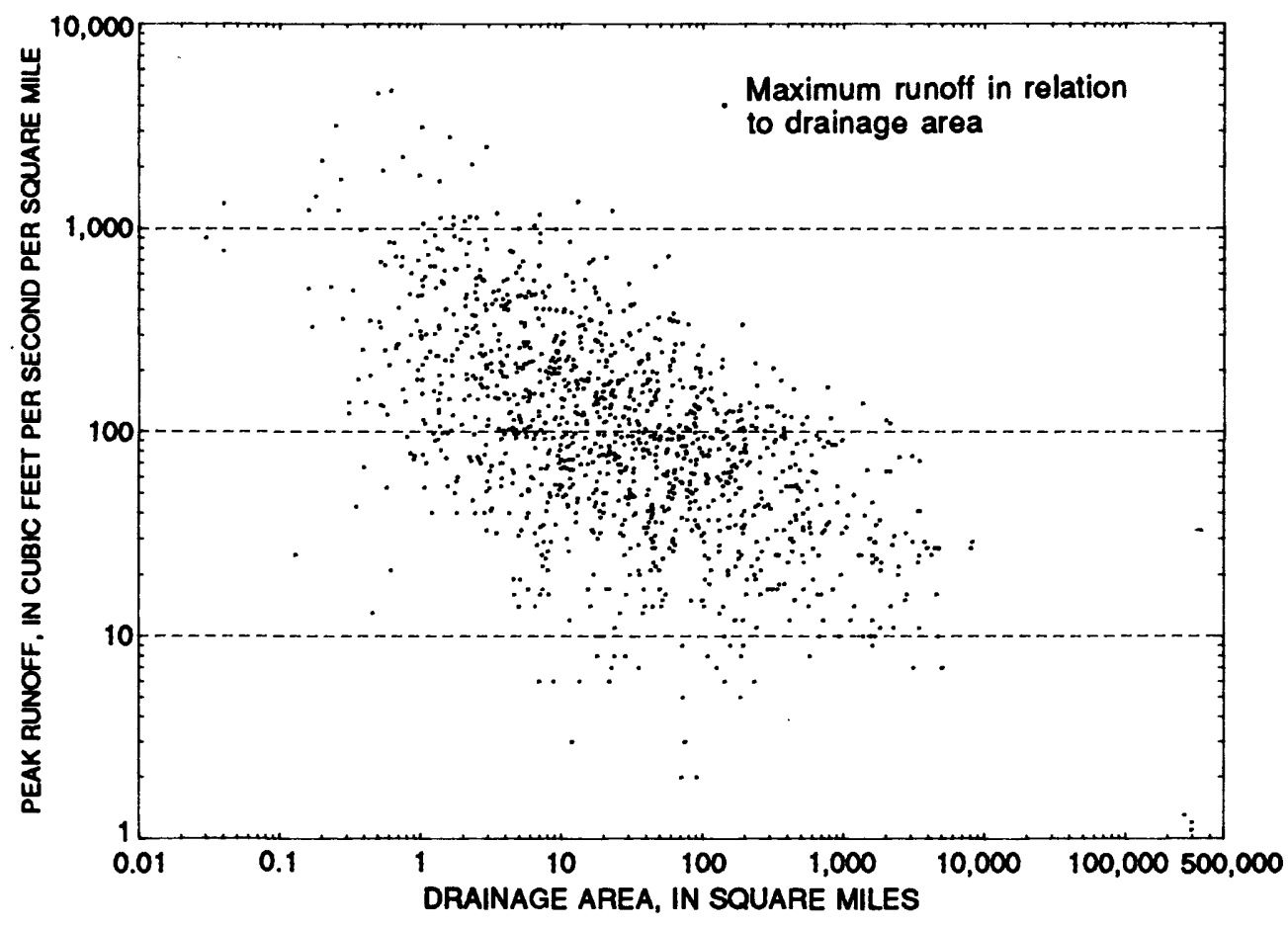

Figure 5.-Maximum known runoff in New York in relation to drainage area. 


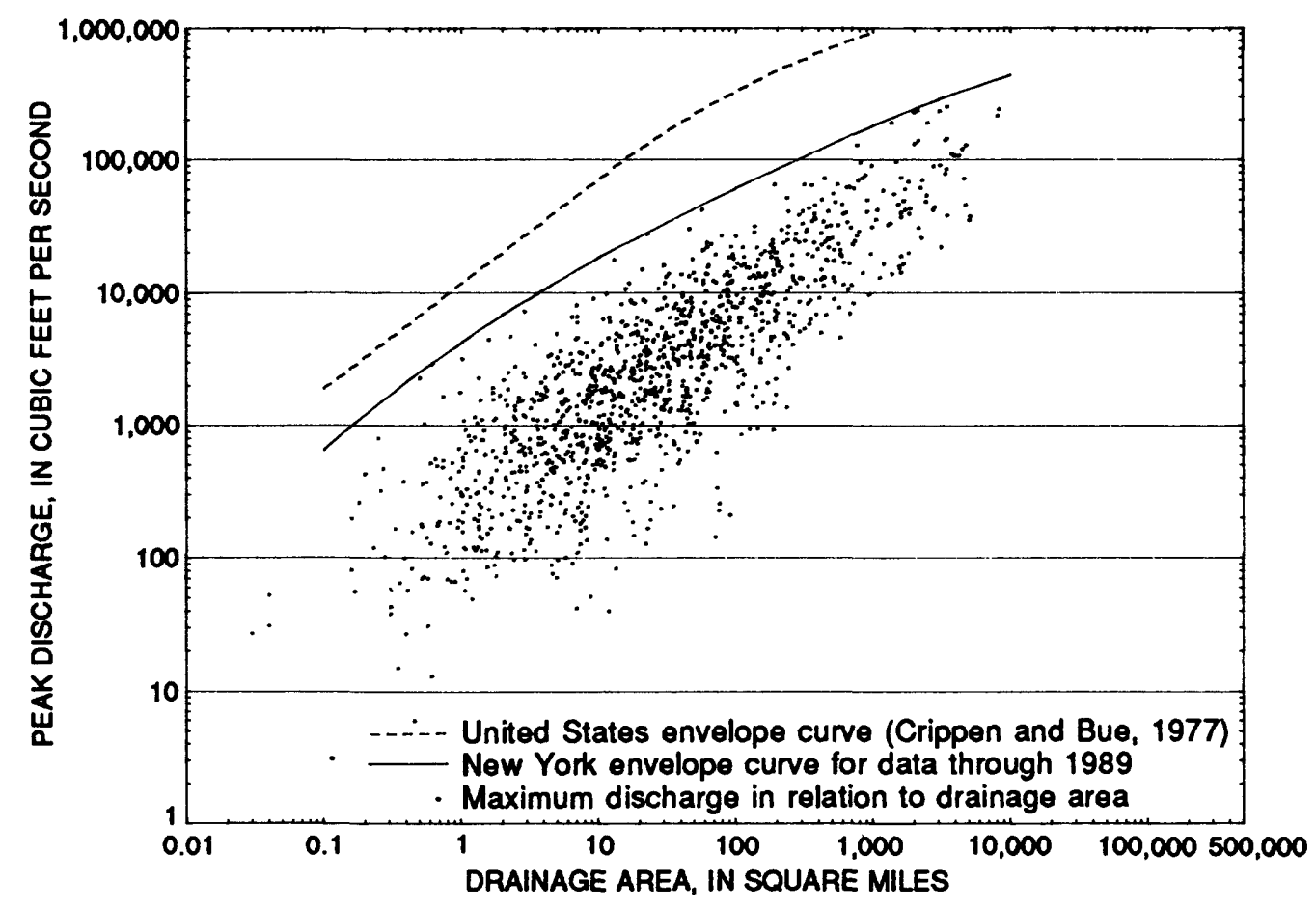

Figure 6.-Maximum known discharges in New York and the United States in relation to drainage area.

10 years of annual peak-flow data. The scatter of the 100-year discharges within each hydrologic region can be attributed to local differences in topographic and climatic variables (other than drainage area) that affect streamflow. Basin characteristics (besides drainage area) that were found to affect peak-discharge response to a statistically significant degree include channel slope, percent of basin storage, mean annual precipitation, percent of basin forest cover, average main-channel elevation, and a basinshape index (Lumia, 1991). Generally, each region shows maximum known discharges (envelope curves) with recurrence intervals exceeding 100 years. (No 100-year discharges are given for Long Island, primarily because manmade changes have affected peak flows within these basins over the years.) Data from three sites on the St. Lawrence and Niagara Rivers are not included in the plots because the basins are too large and the rivers are regulated.

The envelope curves shown for each hydrologic region in figure 7 are plotted together for comparison in figure 8 (p. 14). The greatest maximum known discharges in relation to drainage area are in hydrologic region 6 , which includes much of the area in which hurricane Agnes caused major flooding in 1972, and the smallest are on Long Island. As additional peakdischarge data become available, regional envelope curves might need to be updated.

Peak discharges resulting from once-only events, such as dam failure, were not used in development of any of the envelope curves presented herein, and the curves are not associated with specific flood frequencies or probabilities. Discharge recurrence intervals for rural, unregulated sites in table 2 can be calculated from procedures described by Lumia (1991).

Users of this report are invited to submit evidence of peak stages and discharges at sites not listed in this compilation, or data that are known to exceed those listed, to:

\section{U.S. Geological Survey P.O. Box 1669}

Albany, NY 12201 

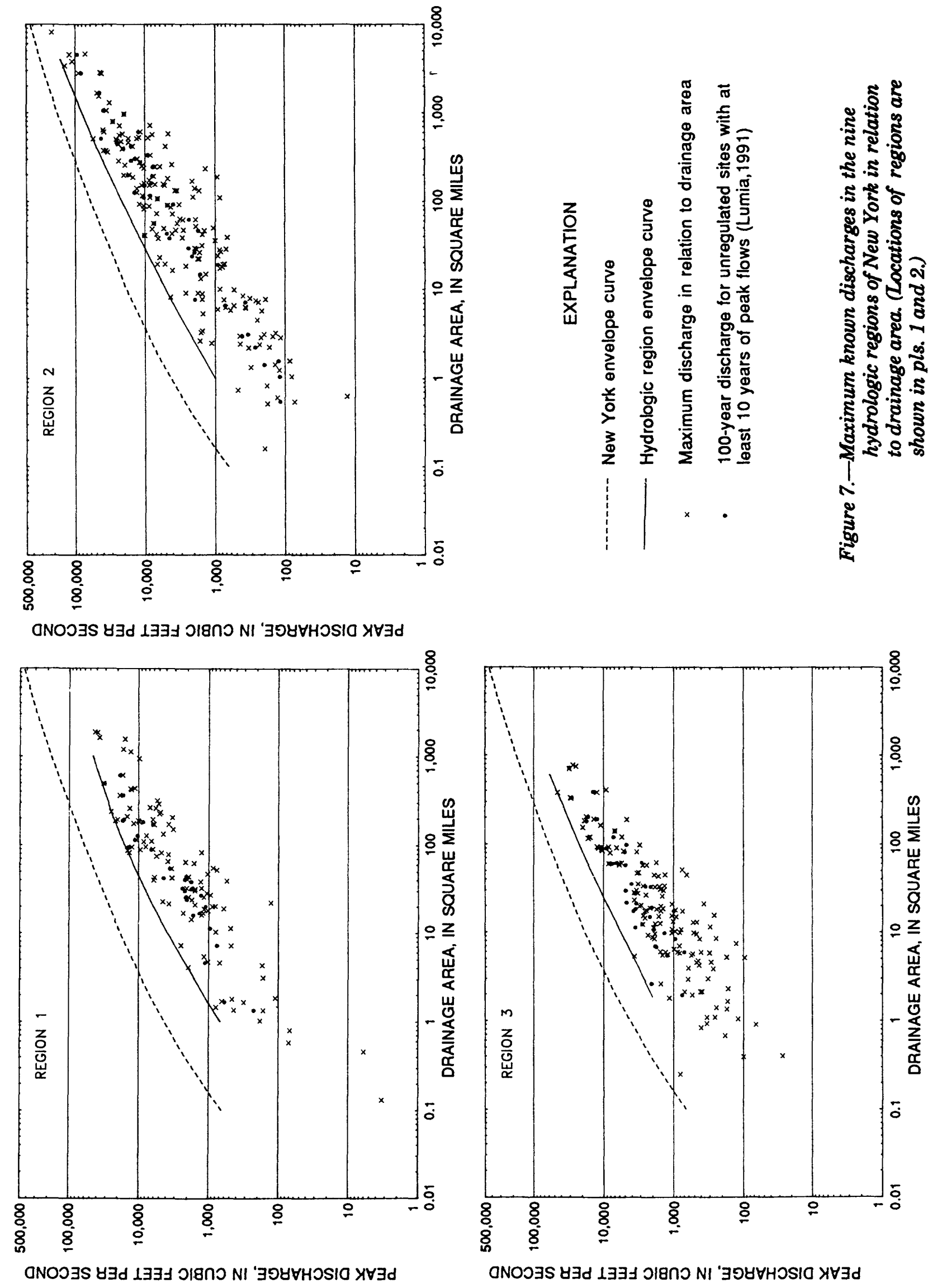

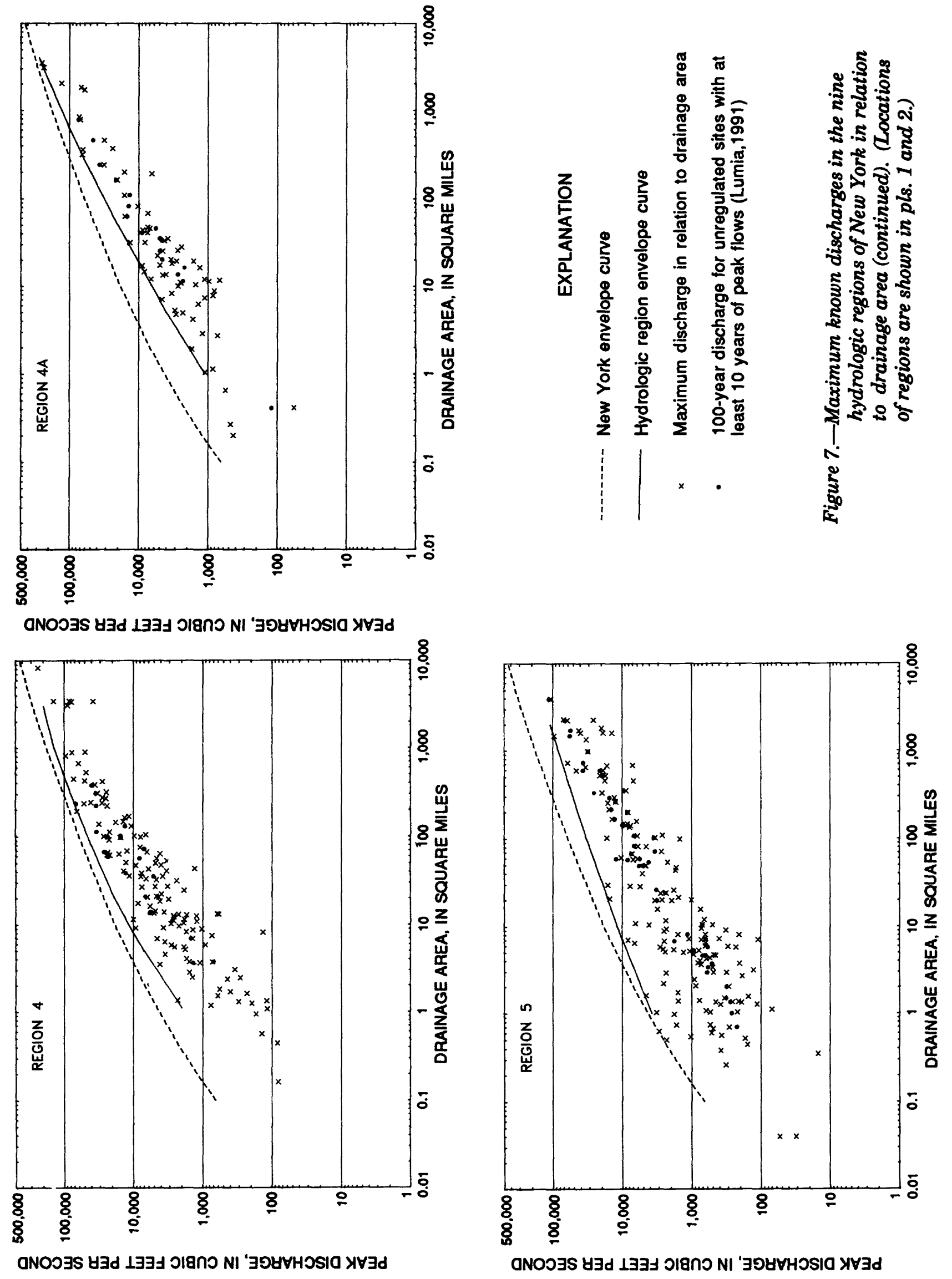

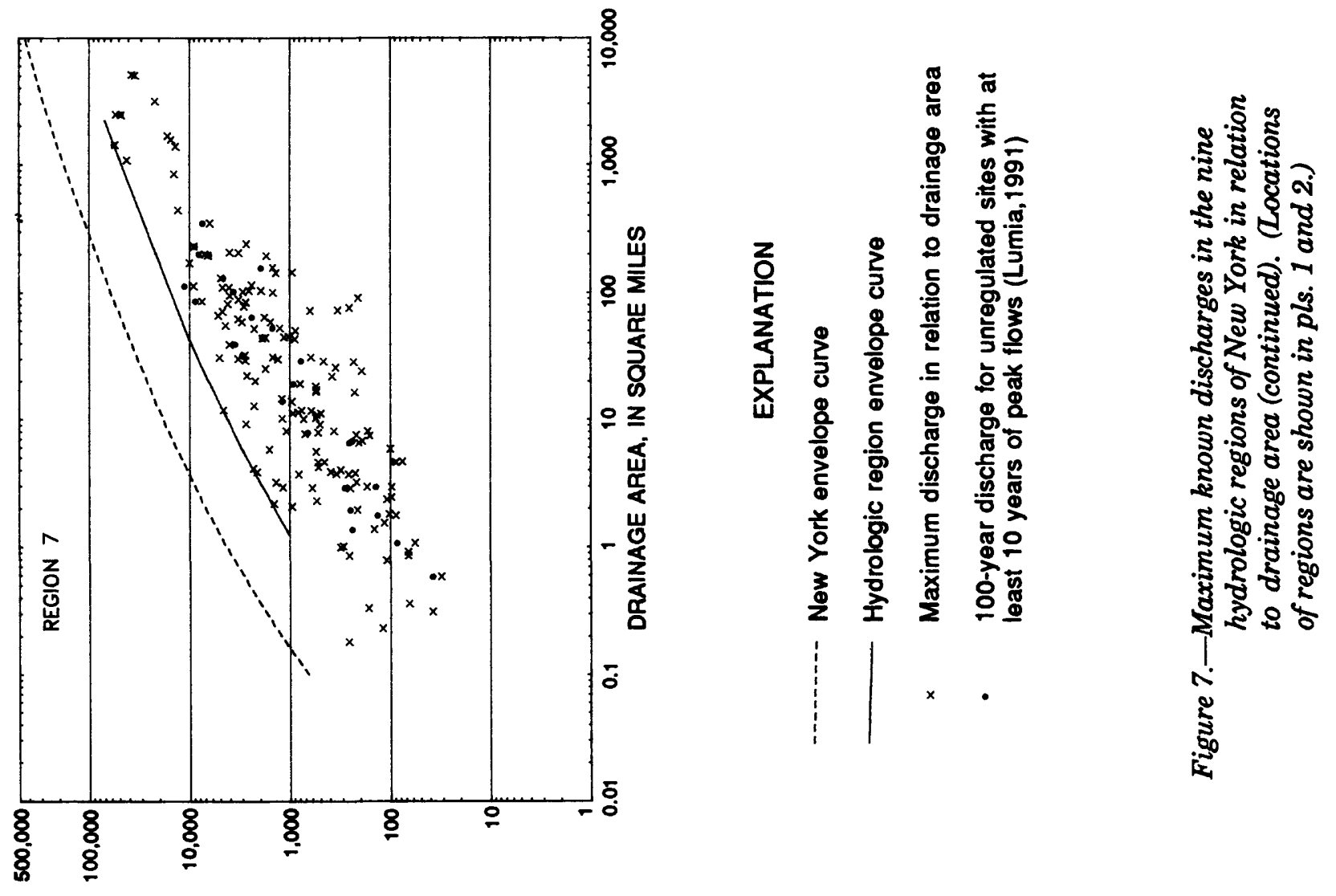

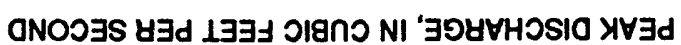
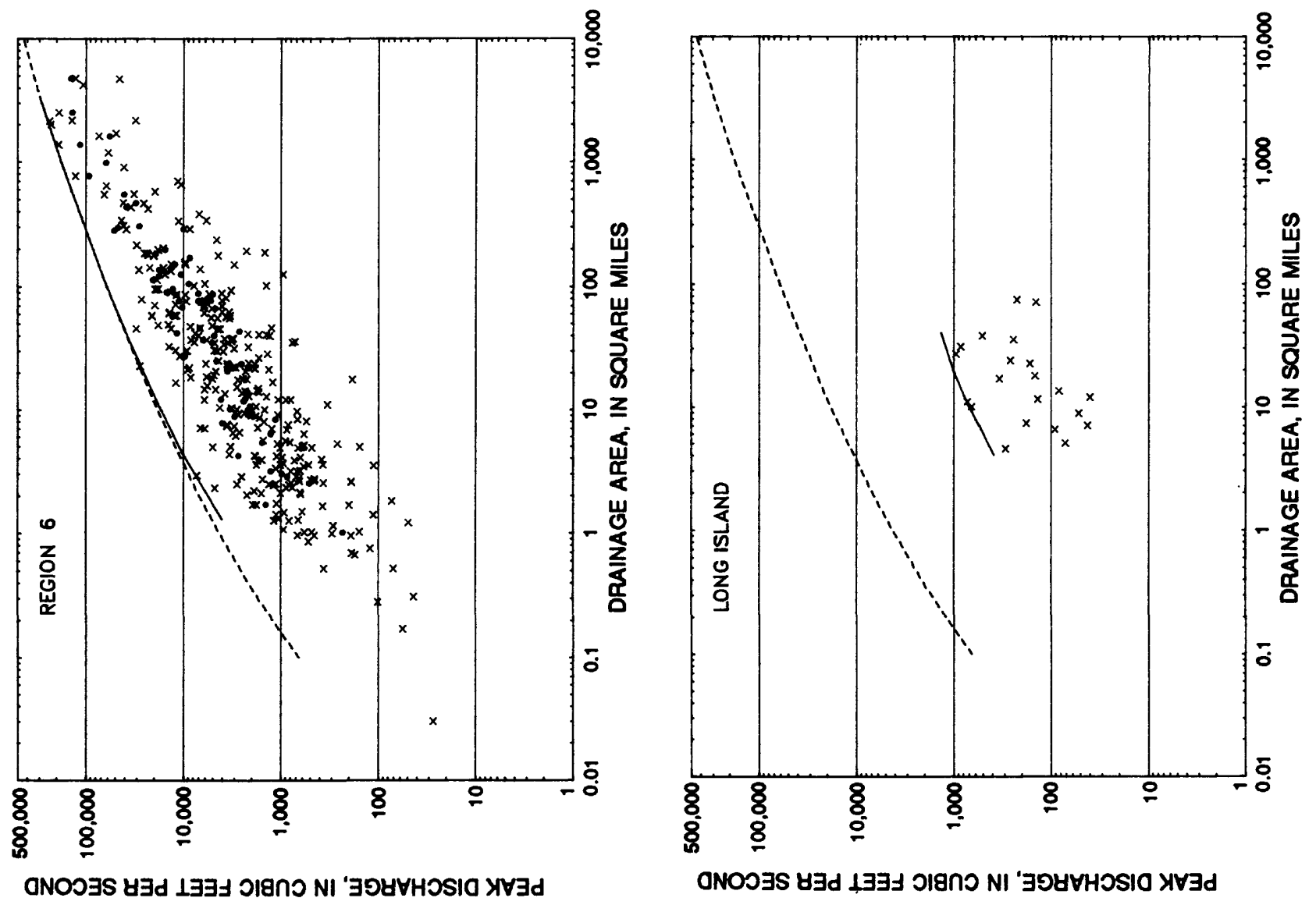


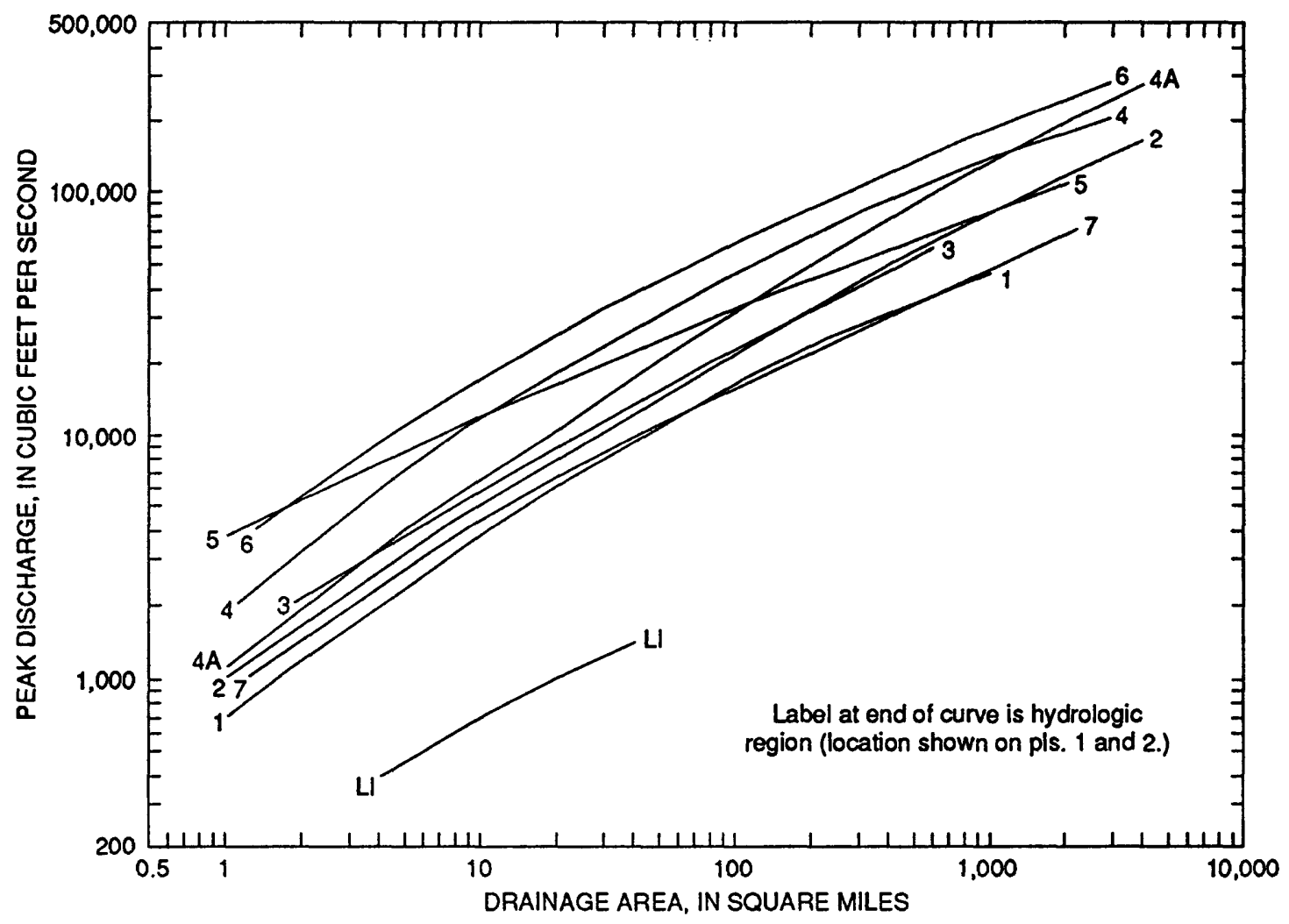

Figure 8.-Envelope curves for nine hydrologic regions of New York. (Locations of regions are shown in pls. 1 and 2.)

\section{SUMMARY}

The USGS, in cooperation with the New York State Department of Transportation, compiled maximum known stages and discharges of New York streams that occurred during 1865-1989. Most of the peak data were obtained from files and previous reports of the USGS, but State, local, and other Federal agencies and private organizations contributed additional peak-data information. Data from 1,280 sites on 863 streams are given.

The data are listed by major drainage basin and by USGS station number (downstream order), station name, county, type and period of record, date of flood, gage height, discharge, discharge per square mile, and remarks on gage height and discharge. An alphabetical listing of stations is included that gives latitude and longitude, county, major basin, stream to which the site is tributary, number of miles above mouth, and USGS topographic quadrangle. A description of five selected floods during 1913-85 is also included.

A comparison of maximum known discharges per square mile in New York with those from sites throughout the United States suggests a smaller flood-discharge potential per square mile in New York than in other areas of potentially high flood discharge within the country. Curves that envelop the upper limit of maximum known discharges of the nine hydrologic regions in New York indicate that parts of western New York and the Catskill Mountains area have the largest documented discharges per square mile in the State, and Long Island has the smallest. 


\section{SELECTED REFERENCES}

Bailey, J.F., Patterson, J.L., Paulhus, J.L.H., 1975, Hurricane Agnes rainfall and floods, June-July 1972: U.S. Geological Survey Professional Paper 924, $403 \mathrm{p}$.

Bodhaine, G.L., 1968, Measurement of peak discharge at culverts by indirect methods: U.S. Geological Survey Techniques of Water-Resources Investigations, Book 3, Chap. A3, 60 p.

Bogart, D.B., 1960, Floods of August-October 1955, New England to North Carolina: U.S. Geological Survey Water-Supply Paper 1420, 854 p.

Cohen, Philip, Franke, O.L., and McClymonds, N.E., 1969, Hydrologic effects of the 1962-66 drought on Long Island, New York: U.S. Geological Survey Water-Supply Paper 1879-F, 17 p.

Cox, H.J., 1913, Climatological Service, District No. 4, The Lake Region, report for March 1913: U.S. Department of Agriculture, Weather Bureau, 13 p.

Crippen, J.R., and Bue, C.D., 1977, Maximum floodflows in the conterminous United States: U.S. Geological Survey Water-Supply Paper $1887,52 \mathrm{p}$.

Cry, G.W., 1965, Tropical cyclones of the North Atlantic Ocean, Technical Paper No. 55: U.S. Department of Commerce, Laboratory of Climatology, U.S. Weather Bureau, Washington, D.C., $148 \mathrm{p}$.

Dalrymple, Tate, and Benson, M.A., 1967, Measurement of peak discharge by the slope-area method: U.S. Geological Survey Techniques of WaterResources Investigations, Book 3, Chap. A2, 12 p.

Dougherty, D.F., 1960, Maximum known discharge of New York streams: U.S. Geological Survey, $32 \mathrm{p.}$

Dunn, Bernard, 1970, Maximum known stages and discharges of New York streams through 1967: New York State Conservation Department, Water Resources Commission Bulletin 67,57 p.

Eissler, B.B., and Zembrzuski, T.J., Jr., 1974, Summary and evaluation of crest-stage gage data in New York: U.S. Geological Survey OpenFile Report, 24 p.
Fischer, E.A., 1937, Report on flood conditions in the Genesee River: Rochester, New York, Henderson-Mosher Inc., 251 p.

Gravlee, G.C., Jr., Lumia, Richard, and Wolcott, S.W., 1991, New York floods and droughts, in U.S. Geological Survey, National water summary 1988-89-Hydrologic events and floods and droughts: U.S. Geological Survey Water-Supply Paper 2375, p. 415-424.

Hulsing, Harry, 1967, Measurement of peak discharge at dams by indirect methods: U.S. Geological Survey Techniques of WaterResources Investigations, Book 3, Chap. A5, $29 \mathrm{p}$.

Ingram, W.T., 1969, Glossary, water and wastewater control engineering: Joint editorial board, American Public Health Association, American Society of Civil Engineers, American Water Works Association, and Water Pollution Control Federation, 387 p.

Langbein, W.B., 1947, Major winter and nonwinter floods in selected basins in New York and Pennsylvania: U.S. Geological Survey WaterSupply Paper 915, 139 p.

Leonard, I.R., and Dunn, B., 1976, Maximum known stages and discharges of New York streams through 1973: New York State Department of Environmental Conservation Bulletin $72,67 \mathrm{p}$.

Lumia, Richard, 1991, Regionalization of flood discharges for rural, unregulated streams in New York, excluding Long Island: U.S. Geological Survey Water-Resources Investigations Report 90-4197, 119 p.

Lumia, Richard, Burke, P.M., and Johnston, W.H., 1987, Flooding of December 29, 1984, through January 2, 1985, in northern New York State, with flood profiles of the Black and Salmon Rivers: U.S. Geological Survey Water-Resources Investigations Report 86-4191, 53 p.

Matthai, H.F., 1967, Measurement of peak discharge at width contractions by indirect methods: U.S. Geological Survey Techniques of Water-Resources Investigations, Book 3, Chap. A4, 44 p. 


\section{SELECTED REFERENCES (Continued)}

Rafter, G.W., 1905, Hydrology of the State of New York: Albany, N.Y., New York State Museum Bulletin 85, 902 p.

Robideau, J.A., Burke, P.M., and Lumia, Richard, 1984, Maximum known stages and discharges of New York streams through September 1983: U.S. Geological Survey Open-File Report 83-927, $83 \mathrm{p}$.

Speer, P.R., and Gamble, C.R., 1965, Magnitude and frequency of floods in the United States Part 3-A, Ohio River Basin except Cumberland and Tennessee River basins: U.S. Geological Survey Water-Supply Paper 1675, 630 p.

Tice, R.H., 1968, Magnitude and frequency of floods in the United States, Part 1-B, North Atlantic Slope Basins, New York to York River: U.S. Geological Survey Water-Supply Paper 1672, $585 \mathrm{p}$.

U.S. Congress, 1932, Report on the Mohawk River, U.S. 72d Congress, 1st session, House of Representatives Document No. 158.

U.S. Geological Survey, 1952, New Year flood of 1949 in New York and New England: U.S. Geological Survey Circular 155, 109 p.

1960 , Compilation of records of surface waters of the United States through September 1950North Atlantic Slope basins, New York to York River: U.S. Geological Survey Water-Supply Paper 1302, $679 \mathrm{p}$.

1961-75, Water resources data-New York, part 1, Surface water records: U.S. Geological Survey Water-Data Report (issued annually).

1964, Compilation of records of surface water of the United States, October 1950 to September 1960-North Atlantic Slope Basins, New York to York River: U.S. Geological Survey WaterSupply Paper 1722, 578 p.

1971, Index of surface-water records to September 30, 1970, part 1-North Atlantic Slope Basins: U.S. Geological Survey Circular 651, 89 p.

1971 , Index of surface-water records to September 30, 1970, part 3-Ohio River Basins:
U.S. Geological Survey Circular 653, 71 p.

1971 , Index of surface-water records to September 30, 1970, part 4-St. Lawrence River Basin: U.S. Geological Survey Circular 654, 43 p.

1976, Water resources data-New York, water year 1975: U.S. Geological Survey Water-Data Report NY-75-1, 735 p.

1977-80, Water resources data-New York, water years 1976-79, volume 1, New York excluding Long Island; volume 2, Long Island: U.S. Geological Survey Water-Data Report (issued annually).

1981-90, Water resources data-New York, water years 1980-89, volume 1, Eastern New York excluding Long Island; volume 2, Long Island; volume 3, Western New York: U.S. Geological Survey Water-Data Report (issued annually).

U.S. Water Resources Council, 1981, Guidelines for determining floodflow frequency: Hydrology Subcommittee Bulletin 17B, 28 p., appendix.

U.S. Weather Bureau, 1955, Climatological data, August 1955, New York: Department of Commerce, v. 68 , no. 8 , p. $132-148$.

Wagner, L.A., 1982, Drainage areas of New York streams, by river basins-A stream gazeteer, part 1, data compiled as of October 1980: U.S. Geological Survey Open-File Report 81-1055, 359 p.

Wiitala, S.W., 1965, Magnitude and frequency of floods in the United States, part 4, St. Lawrence River Basin: U.S. Geological Survey Water-Supply Paper 1677, 357 p.

Zembrzuski, T.J., Jr., and Dunn, B., 1979, Techniques for estimating magnitude and frequency of floods on rural, unregulated streams in New York State excluding Long Island: U.S. Geological Survey Water-Resources Investigations $79-83,66 \mathrm{p}$.

Zembrzuski, T.J., Jr., and Evans, M.L., 1989, Flood of April 4-5, 1987, in southeastern New York State, with flood profiles of Schoharie Creek: U.S. Geological Survey Water-Resources Investigations Report 89-4084, $43 \mathrm{p}$. 


\section{GLOSSARY}

Backwater.-The increased depth of water upstream from a dam or obstruction in a stream channel resulting from that obstruction.

Continuous-record station.-A stream-gaging station that has automatic instruments for measuring and recording stream stage continuously (or at preselected time intervals).

\section{Contracted-opening discharge measure-} ment.-A determination of peak discharge after a flood by field survey of high-water marks and channel and bridge geometry at a bridge constriction. Discharge is computed from an evaluation of energy changes between the approach section and the downstream side of the constriction (Matthai, 1967).

Datum.-An agreed standard point or plane of stated elevation, noted by permanent benchmarks on some solid immovable structure, from which elevations are measured or to which they are referred.

Discharge.-As applied to a stream or conduit, the rate of flow, or volume of water flowing in the stream or conduit at a given place and within a given period of time.

Downstream order system.-Since October 1, 1950 , the order of listing hydrologic-station records in U.S. Geological Survey reports in a downstream direction along the main stream. All stations on a tributary entering upstream from a mainstream station are listed before that station.

Drainage area.-The area of a drainage basin or watershed, expressed in acres, square miles, or other unit of area. Also called catchment area, watershed, or river basin.

Drainage basin.-An area from which surface runoff is carried away by a single drainage system.

Elevation.-Generally refers to height in feet above National Geodetic Vertical Datum of 1929 (formerly mean sea level). See NGVD.

Flood.-A relatively high flow as measured by either gage height or discharge quantity.
Flood recurrence interval.-The average time interval between occurrences of a flood of equal or greater magnitude. A 100-year flood had a 1percent chance of occurring in any 1-year period.

Flow-over-dam discharge measurement.-A determination of peak discharge after a flood, by field survey of high-water marks and channel and dam geometry. Discharge is computed on the basis of an evaluation of energy changes between the approach section and the control (dam) section (Hulsing, 1967).

Flow-through-culvert discharge measurement.-A determination of peak discharge after a flood, by field survey of high-water marks and channel and culvert geometry. Discharge is computed from an evaluation of energy changes between the approach section and the culvert control section (Bodhaine, 1968).

Gage height.-The height of a water surface as measured on a gage, the zero of the gage is referred to some arbitrary datum.

Miscellaneous-measurement site.-A location other than at a stream-gaging station where limited streamflow data (such as discharge measurements) are collected for some special hydrologic or hydraulic purpose.

\section{NGVD (National Geodetic Vertical Datum} of 1929)-A geodetic datum derived from a general adjustment of the first-order level nets of both the United States and Canada. It was formerly called Sea Level Datum of 1929. Although the datum was derived from the average sea level over a period of many years at 26 tide stations along the Atlantic, Gulf of Mexico, and Pacific Coasts, it does not necessarily represent local sea level at any particular place.

Partial-record station.-A stream-gaging station where limited streamflow data are collected systematically over a period of years for use in hydrologic analyses. The term as used in this report refers to crest-stage information from these sites. (A crest-stage gage registers the peak stage that occurs between inspections of the gage.) 


\section{GLOSSARY (Continued)}

Peak stage.-The maximum water-surface elevation, above an arbitrary datum of reference, that occurs at a given place over a relatively short period.

Rating curve.-A curve representing the relation between gage height (stage) and volume of water per unit time (discharge), flowing in a channel.

Runoff.-That part of precipitation that appears in streams. As used in this report, it is the average number of cubic feet of water flowing per second from each square mile of area drained, assuming that the runoff is distributed uniformly in time and area.

Slope-area discharge measurement.-A determination of peak discharge made after a flood, by field survey of a reach of channel and high-water marks at selected cross sections. The
U.S. Geological Survey applies the Manning equation to compute peak discharge in open channels (Dalrymple and Benson, 1967).

Stage.-The elevation of a water surface above or below an established low-water plane or arbitrary datum of reference. See gage height.

Streamflow-gaging station.-An instrumented site on a stream, where systematic observations of hydrologic data are obtained.

Water year.-A continuous 12 -month period, arbitrarily selected for the presentation of data relative to hydrologic or meteorologic phenomena. The U.S. Geological Survey water year represents October 1 through September 30 and it is designated by the calendar year in which it ends. For example, October 1, 1980 through September 30, 1981 is the 1981 water year. 


\section{Table 2}

\section{Maximum Known Stages and Dlscharges of New York Streams through September 1989.}

$\begin{array}{lr}\text { Page } & \\ \text { Explanation of Table } 2 & 21 \\ \text { Maximum known stages and discharges of New York streams through } & \\ \text { September } 1989\end{array}$




\section{Explanation of Table 2}

Table 2 (p. 26-84) contains the following categories of information and uses several codes (p. 22-23), footnotes (p. 24-25), and abbreviations, as explained below:

Stream or river basin. - Data are listed by major stream or lake basin in which the site is located (see fig. 1). The sites are listed by the Geological Survey station number (downstream order) followed by the stream name and location, with standard abbreviations:

$$
\begin{array}{lll}
\text { R - river } & \text { TRIB - tributary } & \text { S - south } \\
\text { CR - creek } & \text { NR - near } & \text { E - east } \\
\text { BK - brook } & \text { N - north } & \text { W - west } \\
\text { BR - branch } & &
\end{array}
$$

County.-The county in which the site is located is indicated by a code number; the corresponding name is given on page 22 . County locations are shown in figure 1 and in plates 1 and 2.

Drainage area.-Drainage areas are given in square miles (L.A. Wagner, U.S. Geological Survey, 1982; 1991, written commun.). Those listed for streams on Long Island are only approximate because streamflow is derived primarily from ground water, and ground-water drainage areas can differ from the surface-water drainage areas. Ground-water contribution during peak discharges is considered to be only minor, however.

Period and type of record.-This column represents only those water years in which peakstage or discharge data were obtained; an occasional year or two of peak-flow record may be missing through equipment malfunction or other factors. Water years of record are listed by the type of record collected during the period. Some sites may have had more than one type of record; for example, a continuous-recording gage may have been converted to a crest-stage partialrecord gage, or vice-versa. The type of record, which is indicated by a letter code, is described on page 23 and in the glossary. Historic information obtained outside of a site's period of gaged record is listed under the maximum known stage and discharge column, but a year is not included in the period of record column. Sites with period-of-record codes A, B, D, or E (gaged sites) are shown on plate 1 , and those with code $C$ (miscellaneous-measurement sites) are shown on plate 2 .

Maximum known stage and discharge.The maximum known stage and(or) discharge and date of occurrence during a station's period of record are listed. Historic information obtained outside of the period of record is also listed but its date is not included within the period of record. Discharge is given in cubic feet per second $\left(\mathrm{ft}^{3} / \mathrm{s}\right)$ and in cubic feet per second per square mile $\left[\left(\mathrm{ft}^{3} / \mathrm{s}\right) / \mathrm{mi}^{2}\right]$. If a site is regulated to a known degree, separate entries are listed for preregulation and postregulation conditions, if available. If the maximum gage height (stage) at a station is affected by backwater from ice or debris, the next highest gage height unaffected by backwater is also listed. Water-surface elevation above sea level (National Geodetic Vertical Datum [NGVD] of 1929) is listed for sites where the gage datum is available; where the gage datum is referenced to a datum other than NGVD, a footnote is given.

Remarks on gage height and(or) discharge are designated by letter codes, which are described on page 23. Most codes were taken from the WATSTORE peak-flow file, and several are possible for each entry. If a gaging-station rating curve (see glossary) was developed from an indirect discharge measurement, a code for the type of indirect is given. (See glossary for definitions of types of indirect measurements.) 
Codes and Definitions used in Table 2.

\section{Major Lake and River Basins Listed in Table 2.}

(Locations are shown on fig. 1.)

North Atlantic Slope Basins:

Housatonic River basin

Blind Brook basin

Beaver Swamp Brook basin

Mamaroneck River basin

Hutchinson River basin

Bronx River basin

Streams on Long Island

Hudson River basin

Mohawk River basin

Hackensack River basin

Passaic River basin

Delaware River basin

Susquehanna River basin

\section{Page}

26

26

26

26

27

27

27

28

31

44

45

45

50
Ohio River Basin:

Allegheny River basin

Page

59

St. Lawrence River Basin:

Lake Erie basin

61

Niagara River basin

Lake Ontario basin

Genesee River basin

Oswego River basin

Black River basin

St. Lawrence River Main Stem

Lake Champlain basin
63

64

65

70

77

80

83

County Codes

\begin{tabular}{rlrlrl}
\hline Code & County & Code & County & Code & County \\
\hline 1 & Albany & 43 & Herkimer & 85 & Richmond \\
3 & Allegany & 45 & Jefferson & 87 & Rockland \\
5 & Bronx & 47 & Kings & 89 & St. Lawrence \\
7 & Broome & 49 & Lewis & 91 & Saratoga \\
9 & Cattaraugus & 51 & Livingston & 93 & Schenectady \\
11 & Cayuga & 53 & Madison & 95 & Schoharie \\
13 & Chautauqua & 55 & Monroe & 97 & Schuyler \\
15 & Chemung & 57 & Montgomery & 99 & Seneca \\
17 & Chenango & 59 & Nassau & 101 & Steuben \\
19 & Clinton & 61 & New York & 103 & Suffolk \\
21 & Columbia & 63 & Niagara & 105 & Sullivan \\
23 & Cortland & 65 & Oneida & 107 & Tioga \\
25 & Delaware & 67 & Onondaga & 109 & Tompkins \\
27 & Dutchess & 69 & Ontario & 111 & Ulster \\
29 & Erie & 71 & Orange & 113 & Warren \\
31 & Essex & 73 & Orleans & 115 & Washington \\
33 & Franklin & 75 & Oswego & 117 & Wayne \\
35 & Fulton & 77 & Otsego & 119 & Westchester \\
37 & Genesee & 79 & Putnam & 121 & Wyoming \\
39 & Greene & 81 & Queens & 123 & Yates \\
41 & Hamilton & 83 & Rensselaer & & \\
\hline & & & & & \\
\hline
\end{tabular}


Codes and Definitions Used in Table 2 (continued).

\section{Type of Record}

\begin{tabular}{cl}
\hline Code & \multicolumn{1}{c}{ Definition } \\
\hline A & Active continuous-record site (recording gage) \\
B & Active partial-record site (crest-stage gage, staff gage, etc.) \\
C & Miscellaneous measurement site \\
D & Discontinued continuous-record site \\
E & Discontinued partial-record site
\end{tabular}

\section{Gage Height}

\begin{tabular}{cl}
\hline Code & \multicolumn{1}{c}{ Definition } \\
\hline A & Affected by backwater \\
B & Not the maximum for period of record \\
C & At site and (or) datum different from most recent \\
D & None available \\
E & Estimated \\
F & Gage datum changed during this water year \\
G & From floodmark \\
H & Affected by wave associated with coastal storm surge
\end{tabular}

\section{Discharge}

\begin{tabular}{cl}
\hline Code & \multicolumn{1}{c}{ Definition } \\
\hline A & Maximum daily average \\
B & Estimated \\
C & Affected by dam failure \\
D & Result of hurricane \\
E & Affected to unknown degree by regulation \\
F & Affected by regulation \\
G & Historic peak (determined outside period of gage record) \\
H & Result of ice-jam or debris-dam breakup \\
I & Affected by urbanization or channelization \\
J & Not determined \\
K & Not the maximum for period of record \\
L & Determined by slope-area measurement \\
M & Determined by contracted-opening measurement \\
N & Determined by flow-through-culvert measurement \\
O & Determined by flow-over-dam measurement \\
P & Prior to known regulation
\end{tabular}




\section{Footnotes to Table 2}

1. Mean daily.

2. From U.S. Army Corps of Engineers.

3. Estimated by U.S. Army Corps of Engineers.

4. Estimated.

5. Maximum prior to diversion in November 1955.

6. From Rafter, 1905, p 439-490.

7. Barge Canal Datum.

8. From New York Power and Light Corporation.

9. From U.S. House of Representatives, 1932, Document No. 158.

10. From Consolidated Water Company of Utica.

11. Measured at drainage area $1.13 \mathrm{mi}^{2}$.

12. From State Engineer and Surveyor of New York.

13. Gage height was $>13.6 \mathrm{ft}$ and $<13.9 \mathrm{ft}$.

14. From local residents.

15. From local residents; flood of October 1903 is known to have reached a higher stage.

16. From Fischer, 1937, p. 85, 191-195.

17. An extreme flood occurred 1860-65 with a depth of $12 \mathrm{ft}$ on Cohoes dam and peak discharge estimated $>200,000 \mathrm{ft}^{3} / \mathrm{s}$ (Rafter, 1905, p. 439-490).

18. Tide affected; Fischer, 1937, p. 191-195.

19. From New York City Board of Water Supply.

20. From outside floodmark; gage height in well was $9.87 \mathrm{ft}$, from floodmark.

21. Does not include undetermined amount of flow bypassing gage.

22. Prior to construction of Pepacton Reservoir; site location now within reservoir.

23. Datum of Orange and Rockland Utilities, Inc.

24. From National Weather Service.

25. Datum of Board of Water Supply, City of New York.

26. Local reports indicate that during the flood of July 1935, the roadway near the gage corresponding to a stage of about $18 \mathrm{ft}$ was under water for a short time.

27. From Fretts, Tallamy, and Senior, Consulting Engineers, Williamsville, NY.

28. From William S. Lozier, Inc., Consulting Engineers, Rochester, NY.

29. From floodmark.

30. From U.S. Department of Agriculture, Soil Conservation Service, Bath, NY. 


\section{Footnotes to Table 2 (Continued)}

31. From Elmira City Engineer.

32. From floodmarks from U.S. Army Corps of Engineers; International Great Lakes Datum of 1955.

33. Backwater from ice; from floodmarks from U.S. Army Corps of Engineers, International Great Lakes Datum of 1955.

34. January 1926 to September 1960, daily discharges available in files of U.S. Department of Commerce.

35. From records of Village of Attica.

36. From records of City of Batavia.

37. Does not include a discharge of $4,320 \mathrm{ft}^{3} / \mathrm{s}$ estimated by U.S. Army Corps of Engineers to have bypassed gage.

38. Greater flood occurred March 1865, discharge not determined (Rafter, 1905, p. 439-490).

39. Record represents net diversion from Niagara River basin into Oswego River basin through Erie (Barge) Canal.

40. From U.S. Army Corps of Engineers and includes overflow from Dyke Creek estimated to be $5,600 \mathrm{ft}^{3} / \mathrm{s}$.

41. Result of dewatering of Erie (Barge) Canal through accidental break in canal wall at Bushnell Basin.

42. From New York State Department of Transportation.

43. Flood of October 28, 1981, was considerably higher; discharge not determined.

44. Noted as West Camden with a drainage area of $47.5 \mathrm{mi}^{2}$ (Rafter, 1905, p. 439-490).

45. Prior to 1906.

46. Result of release of upstream debris jam; reconstructed maximum discharge was $16,000 \mathrm{ft}^{3} / \mathrm{s}$ after adjusment for storage effects.

47. Estimated by U.S. Army Corps of Engineers from high-water mark at upstream side of New York State Route 173 bridge.

48. From Oswego River Watershed Corporation.

49. Prior to 1905.

50. Elevation at downstream side of bridge on Glenfield-Donnattsburg Road at Otter Creek.

51. From Hudson River-Black River Regulating District.

52. Site now under water.

53. According to powerplant operators.

54. Maximum daily elevation; International Great Lakes Datum.

55. Floodmark $560 \mathrm{ft}$ upstream in generator room below dam. 


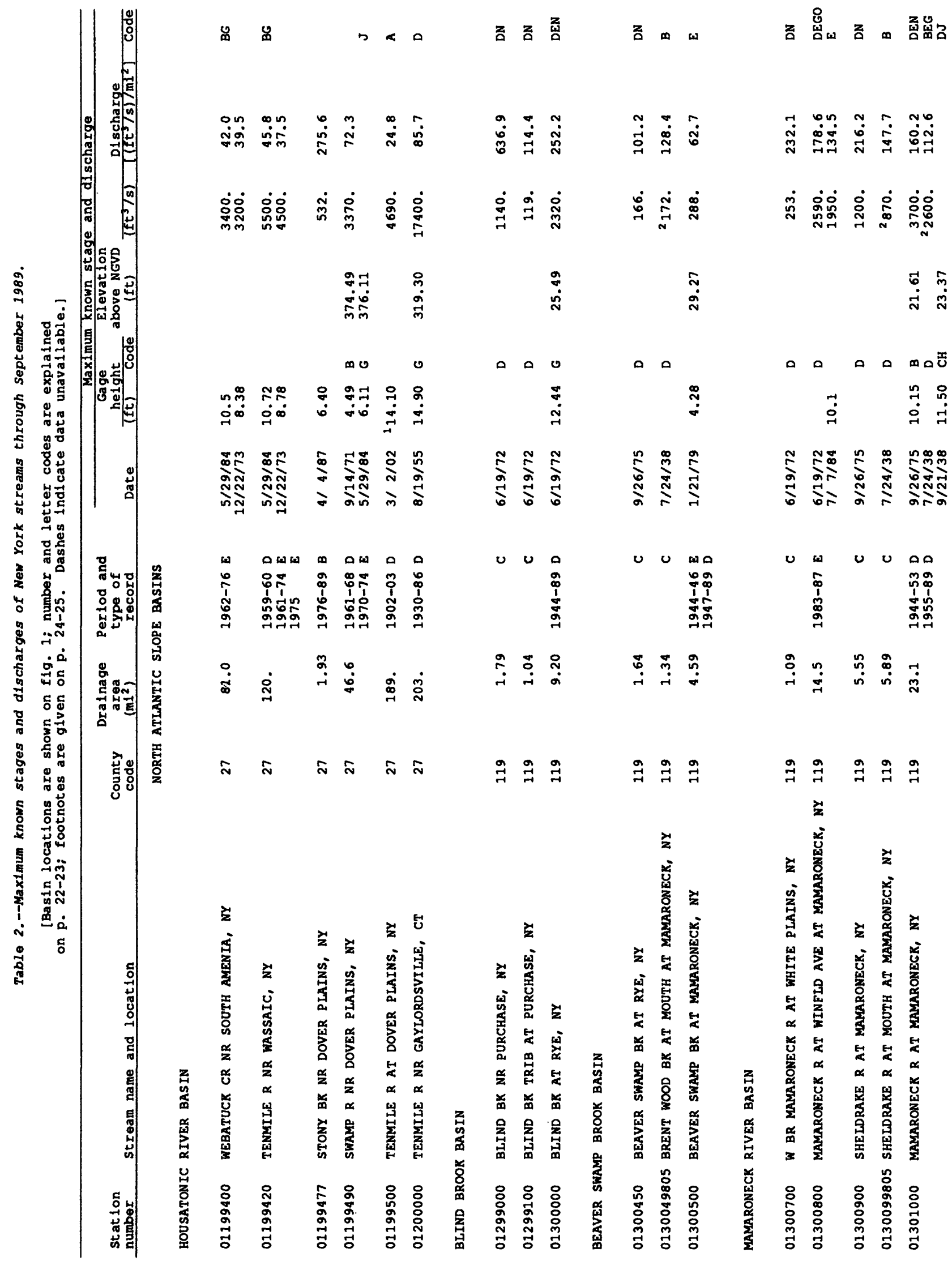




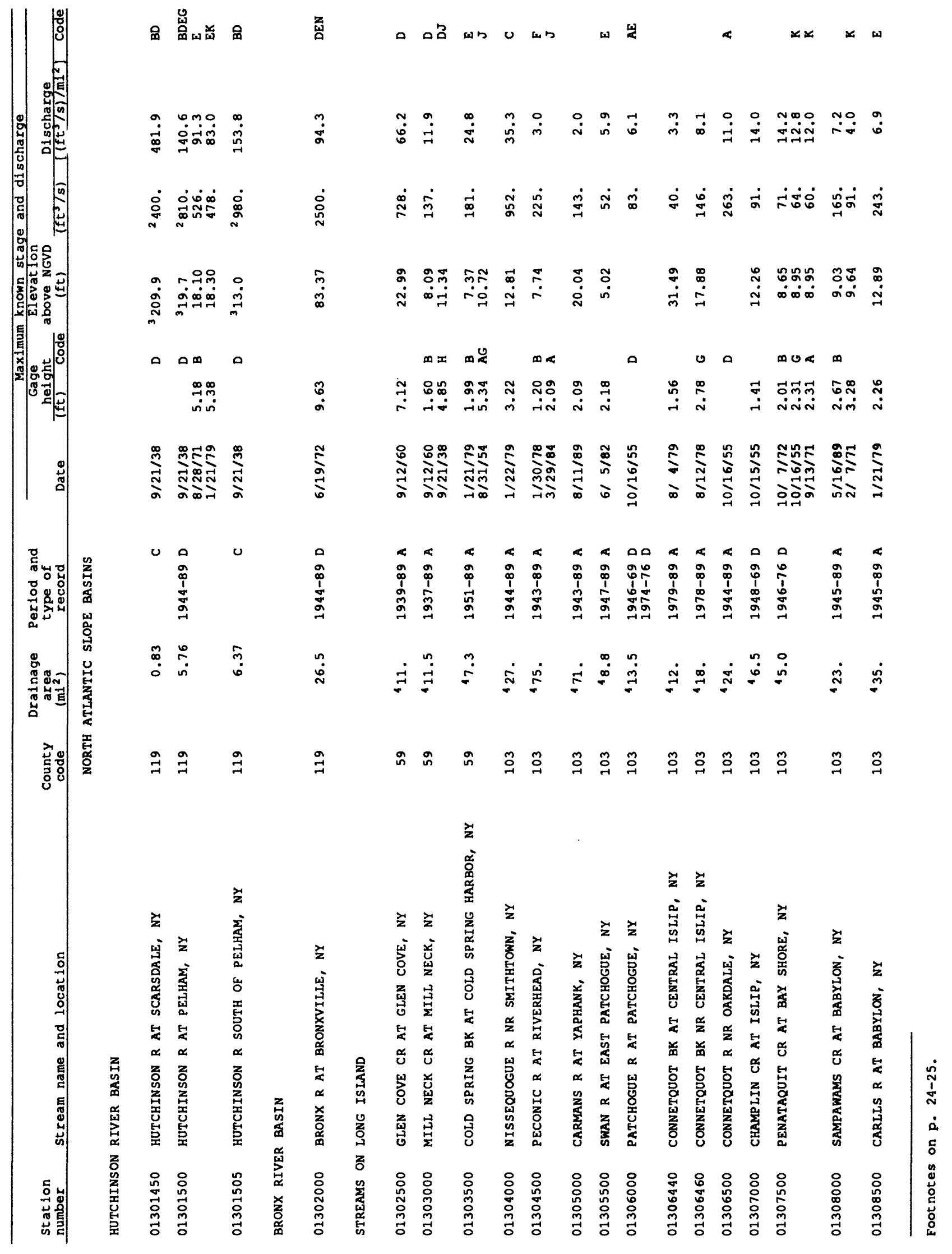




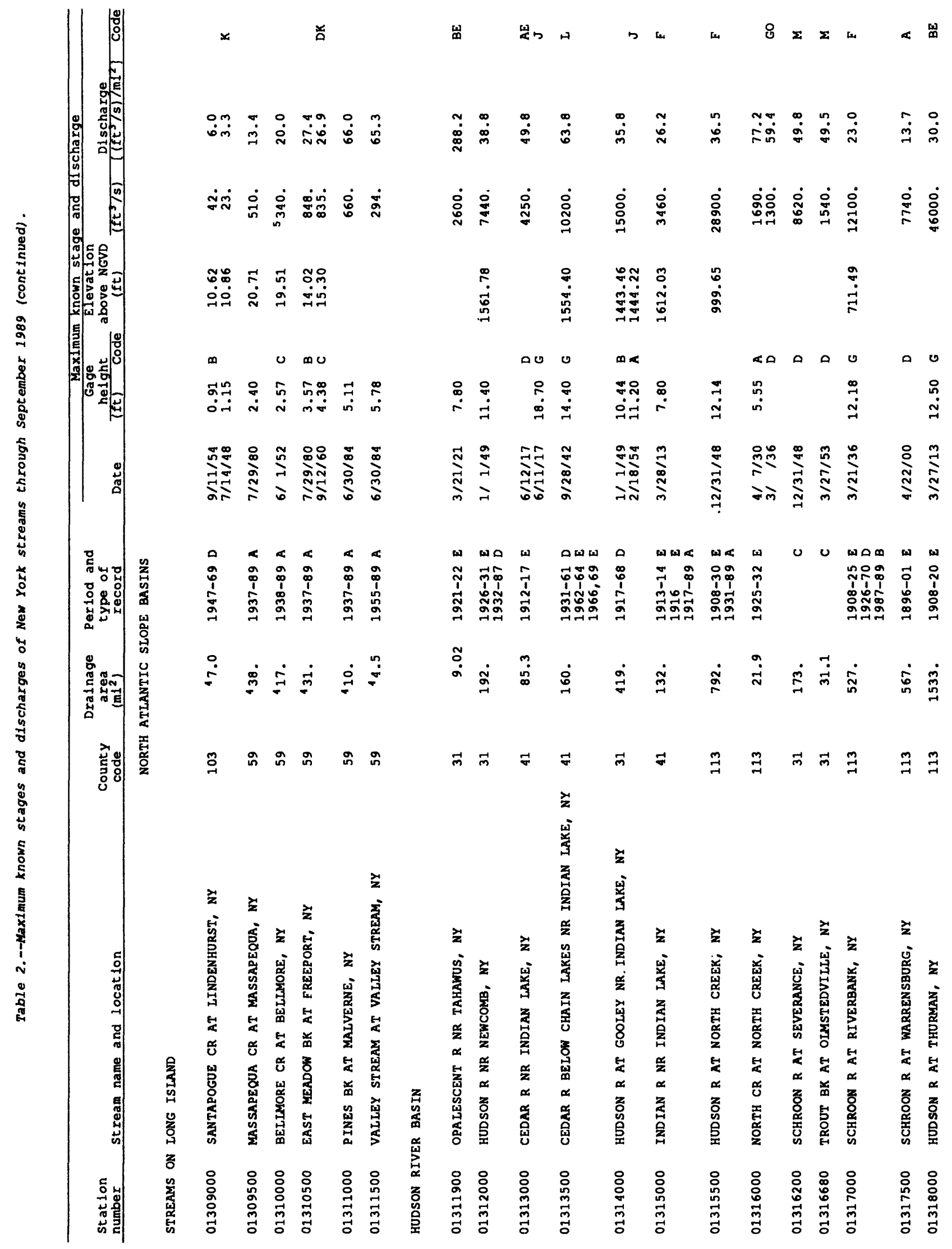




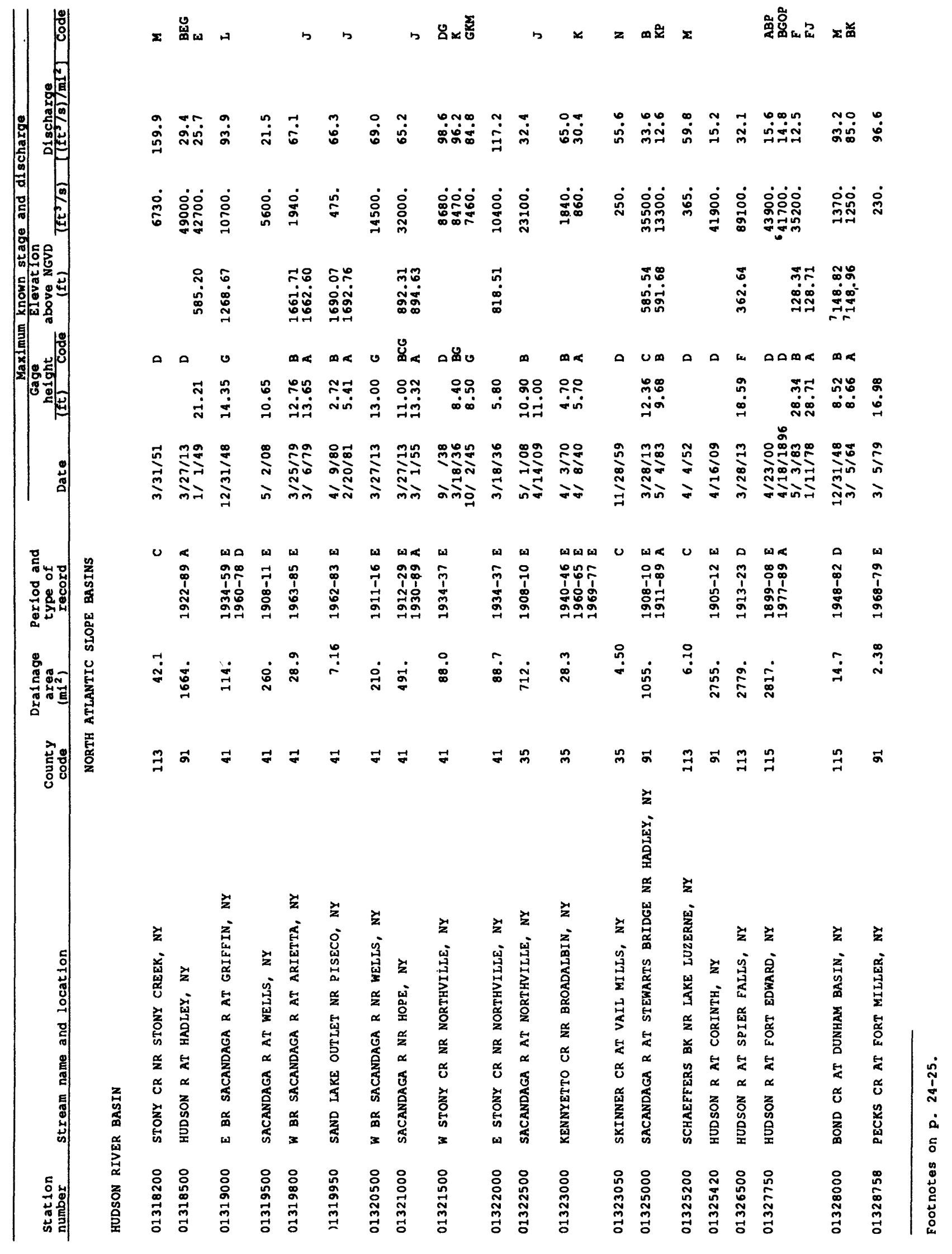




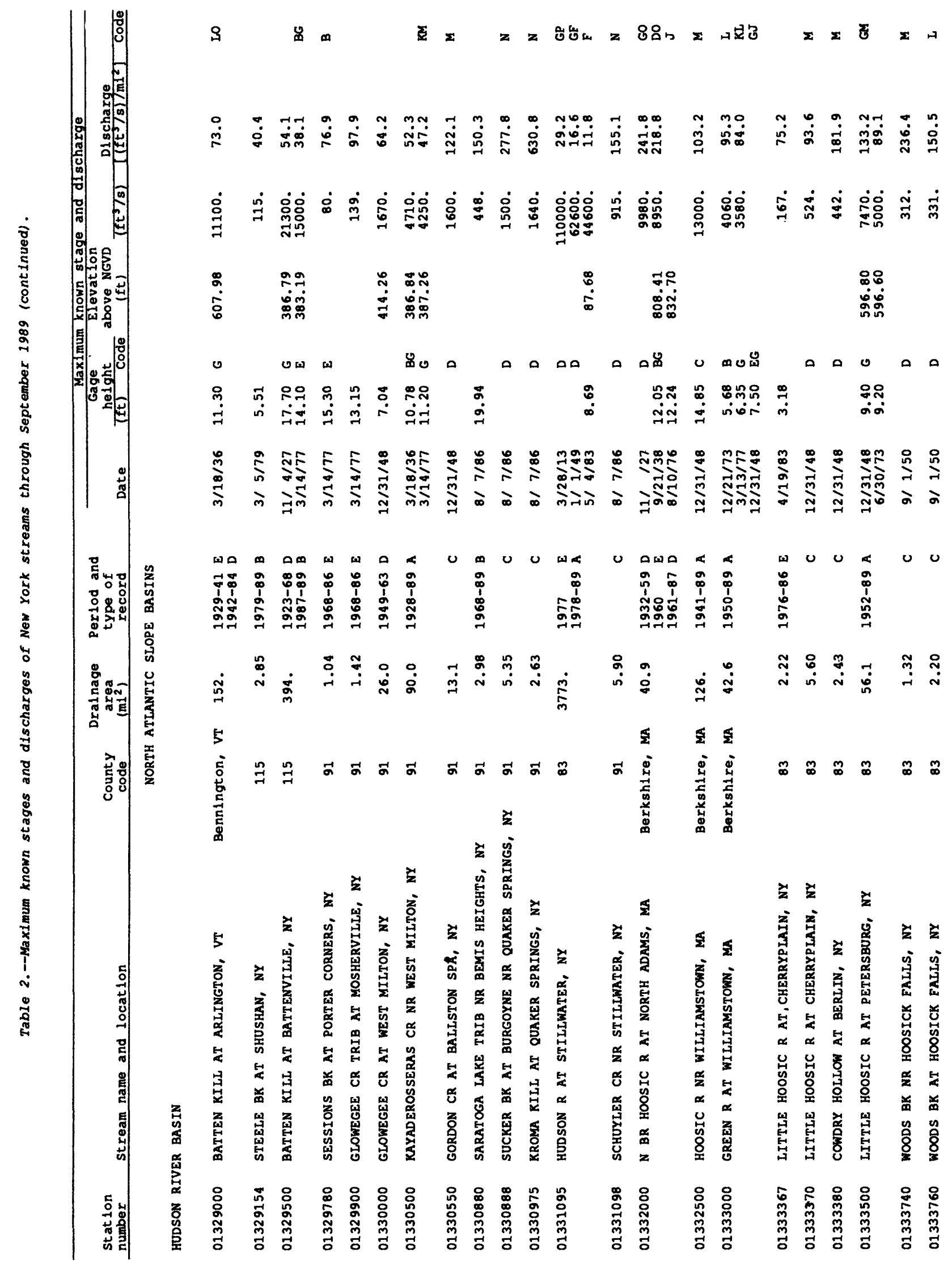




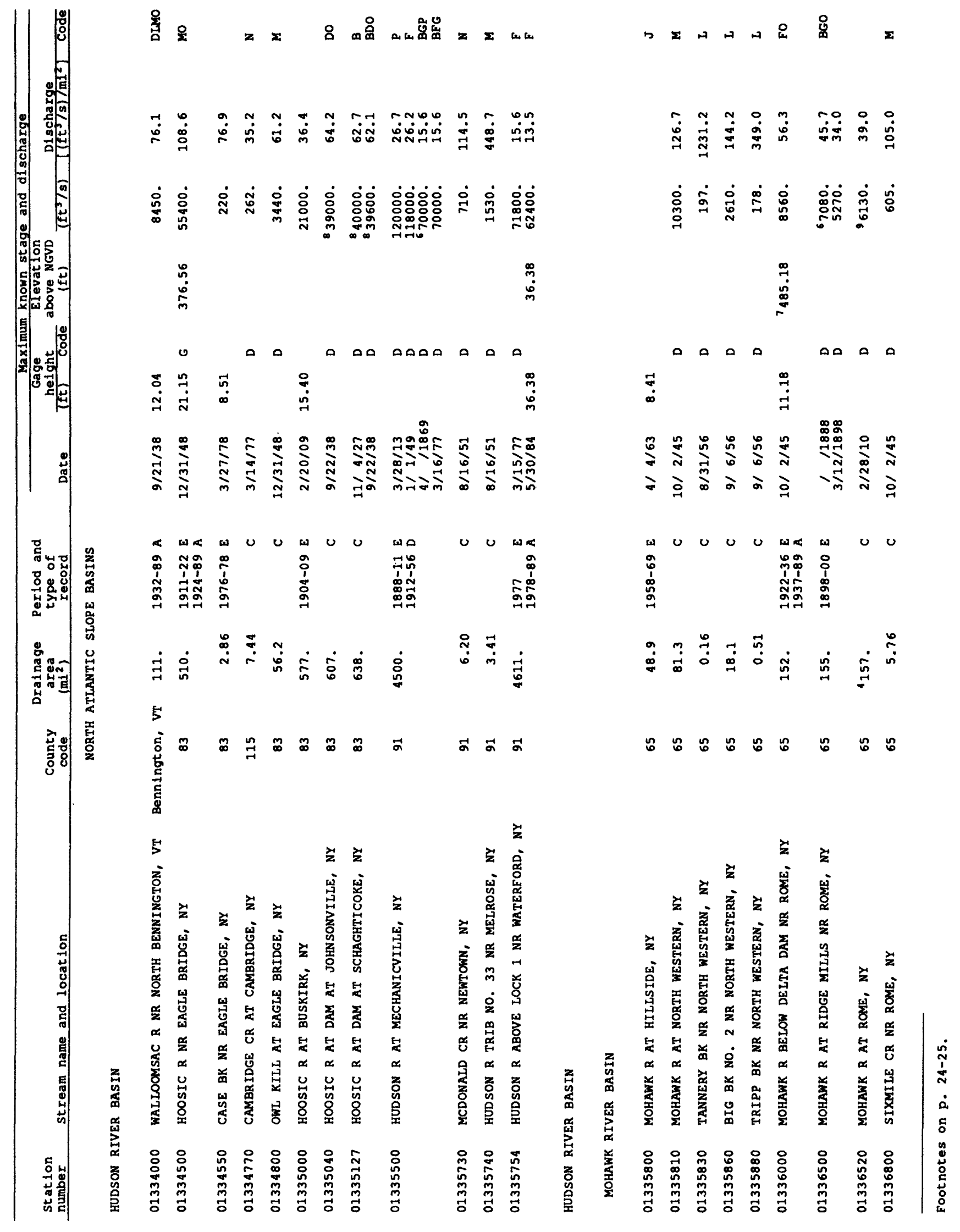




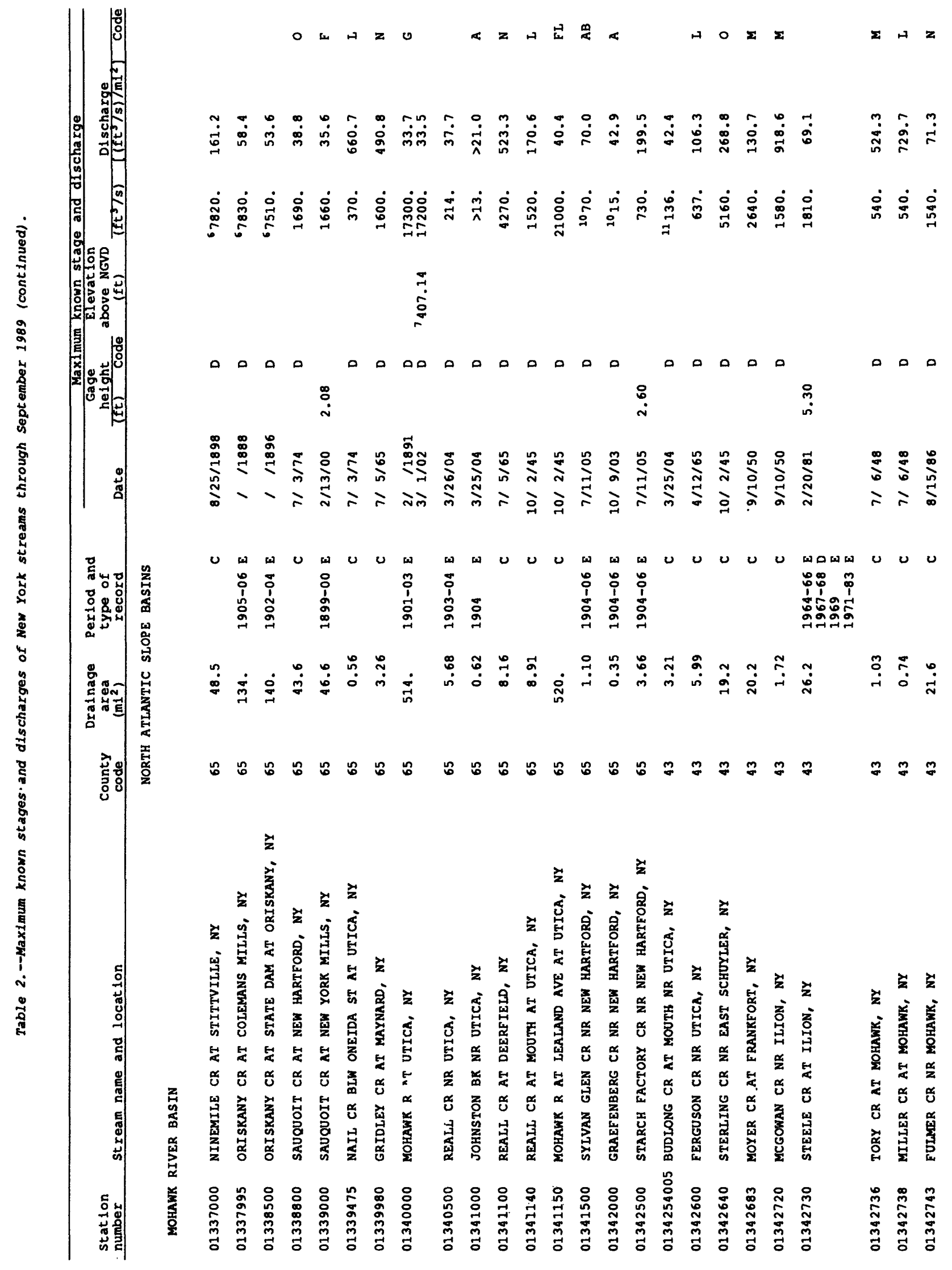




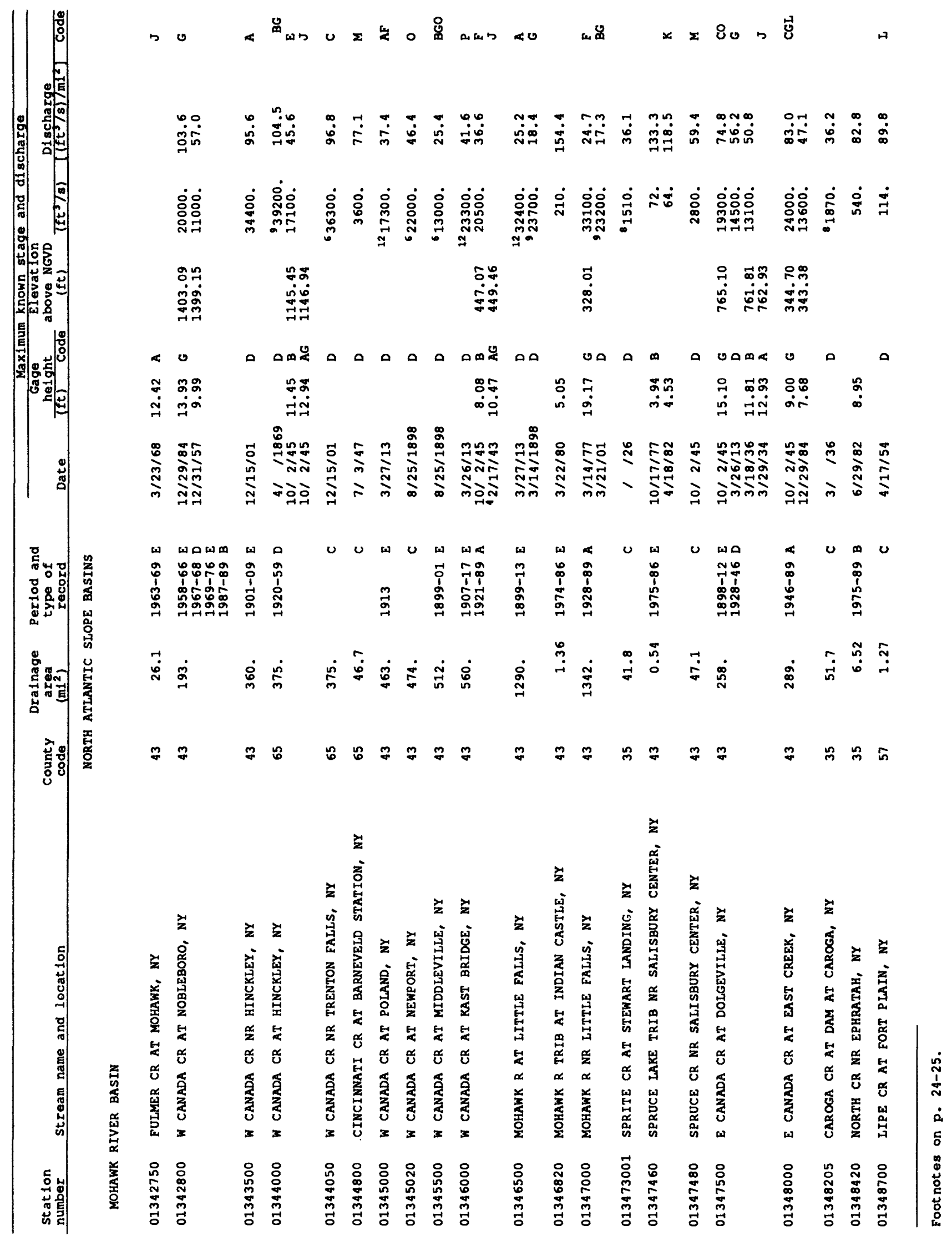




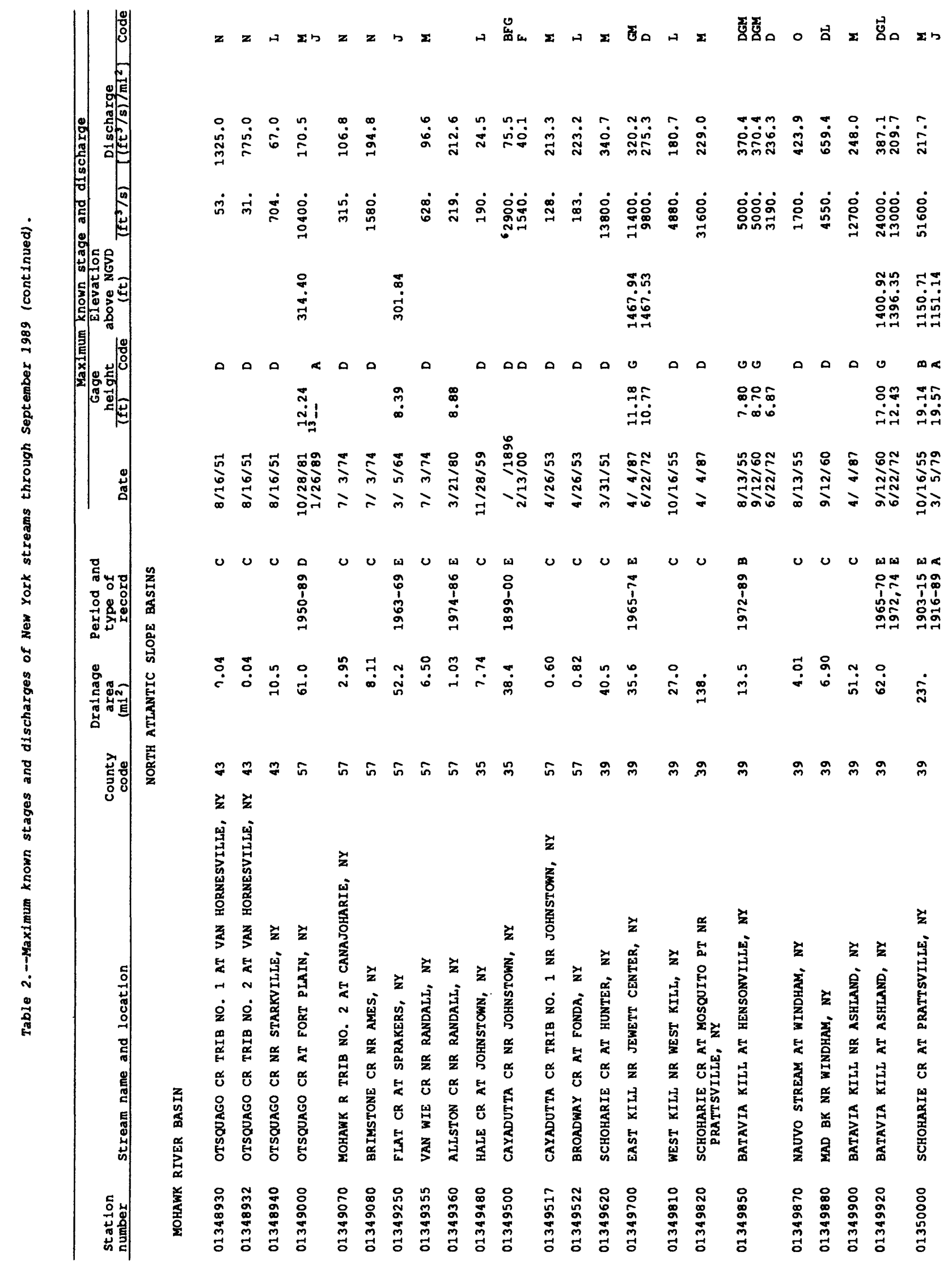




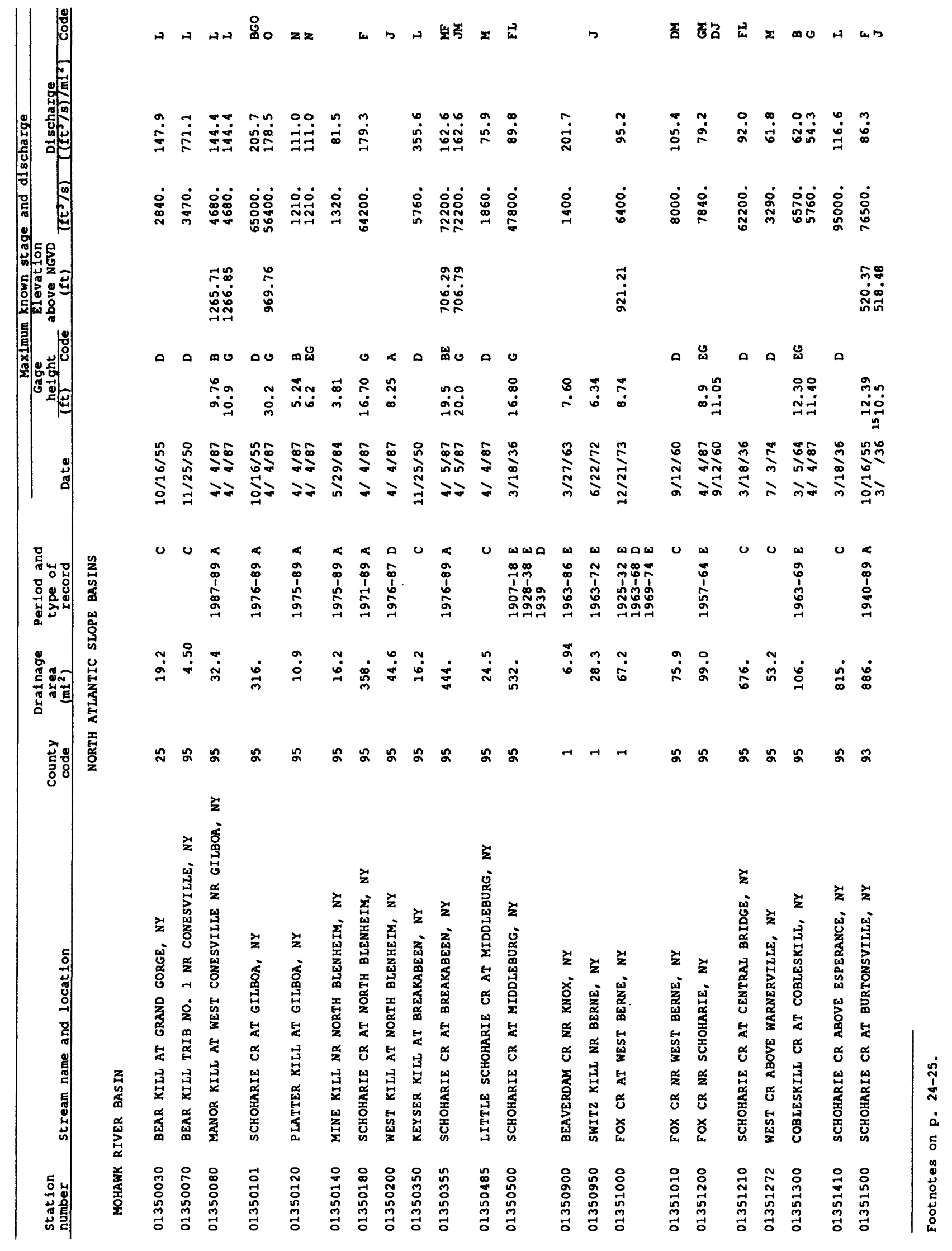




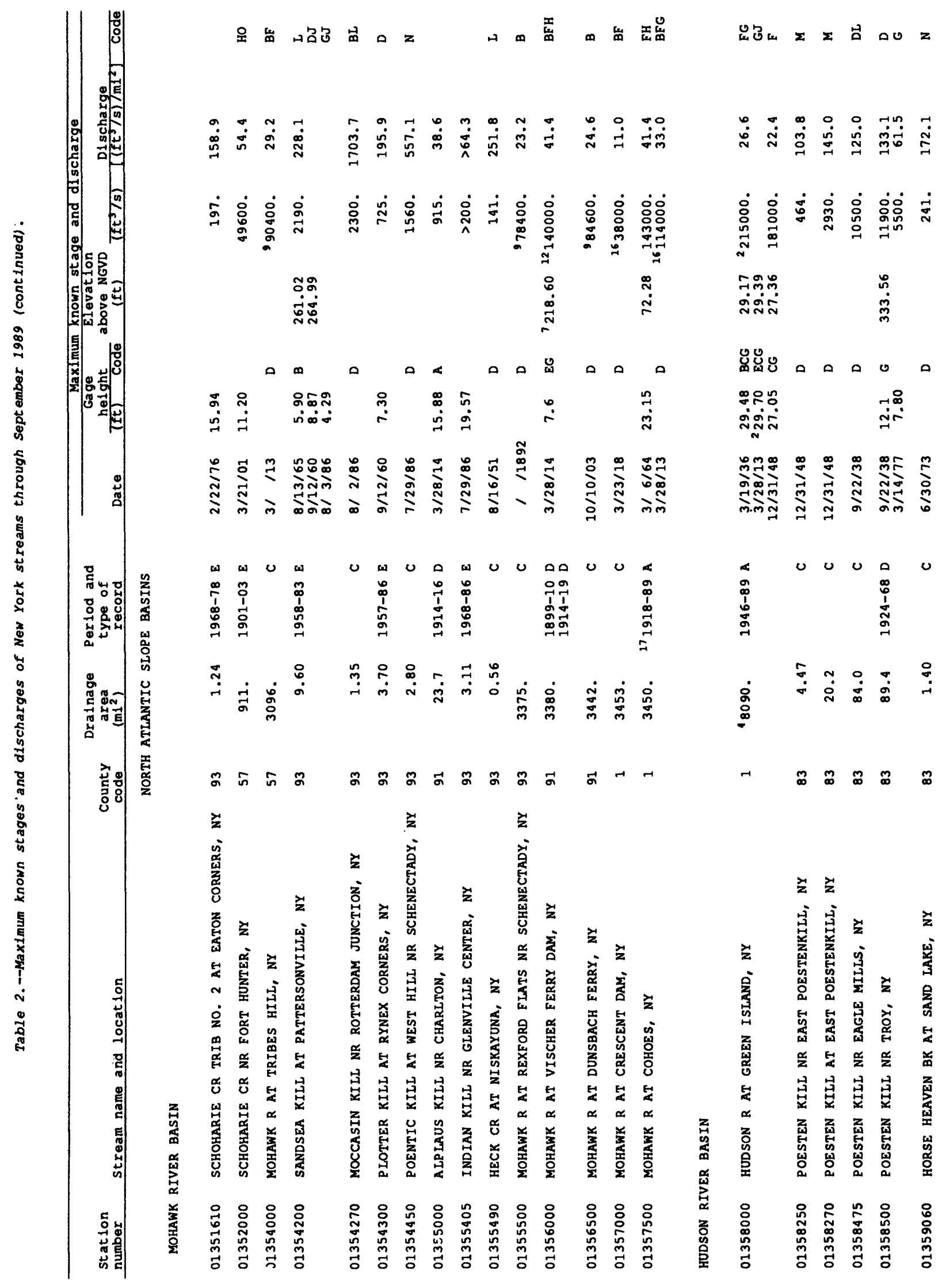




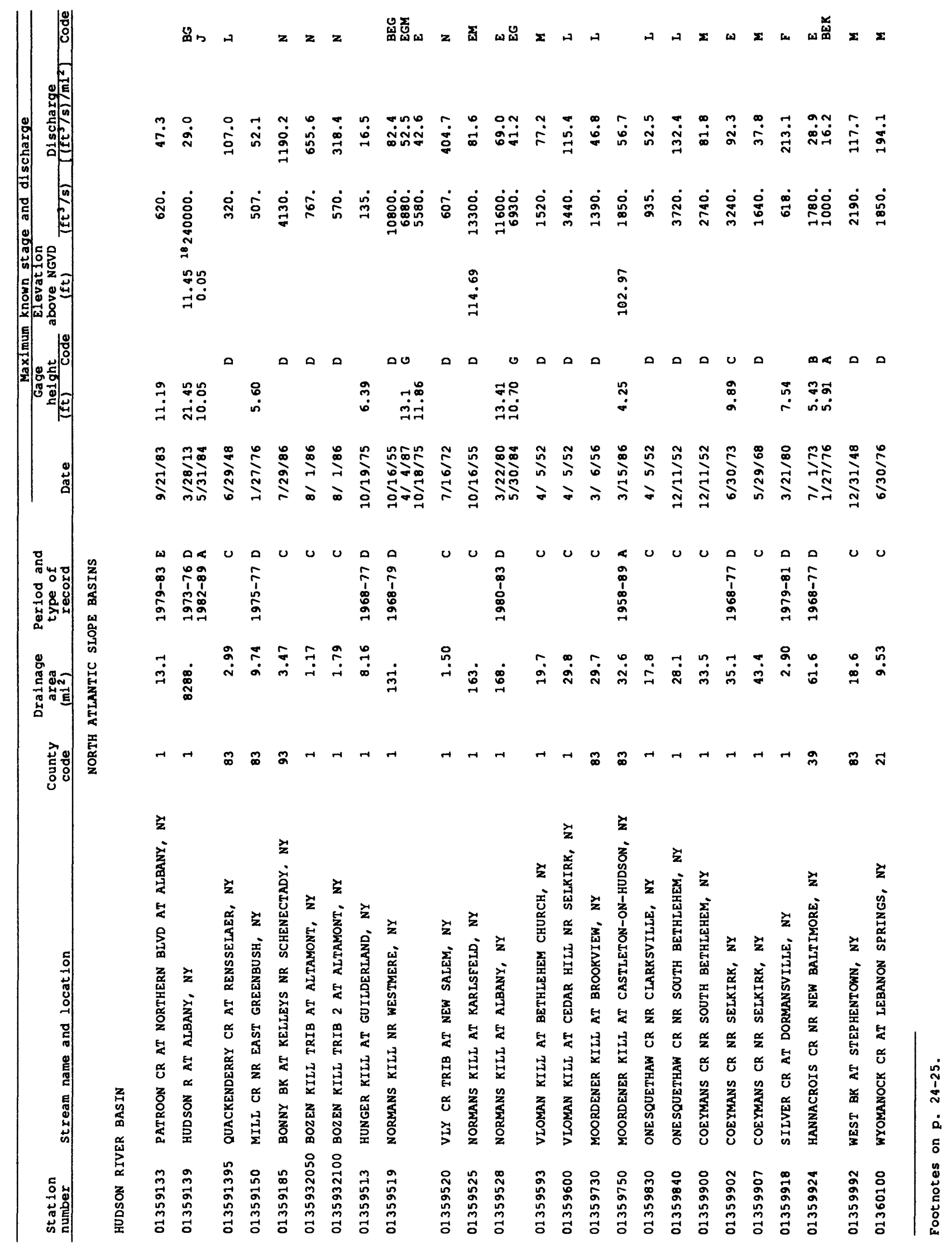




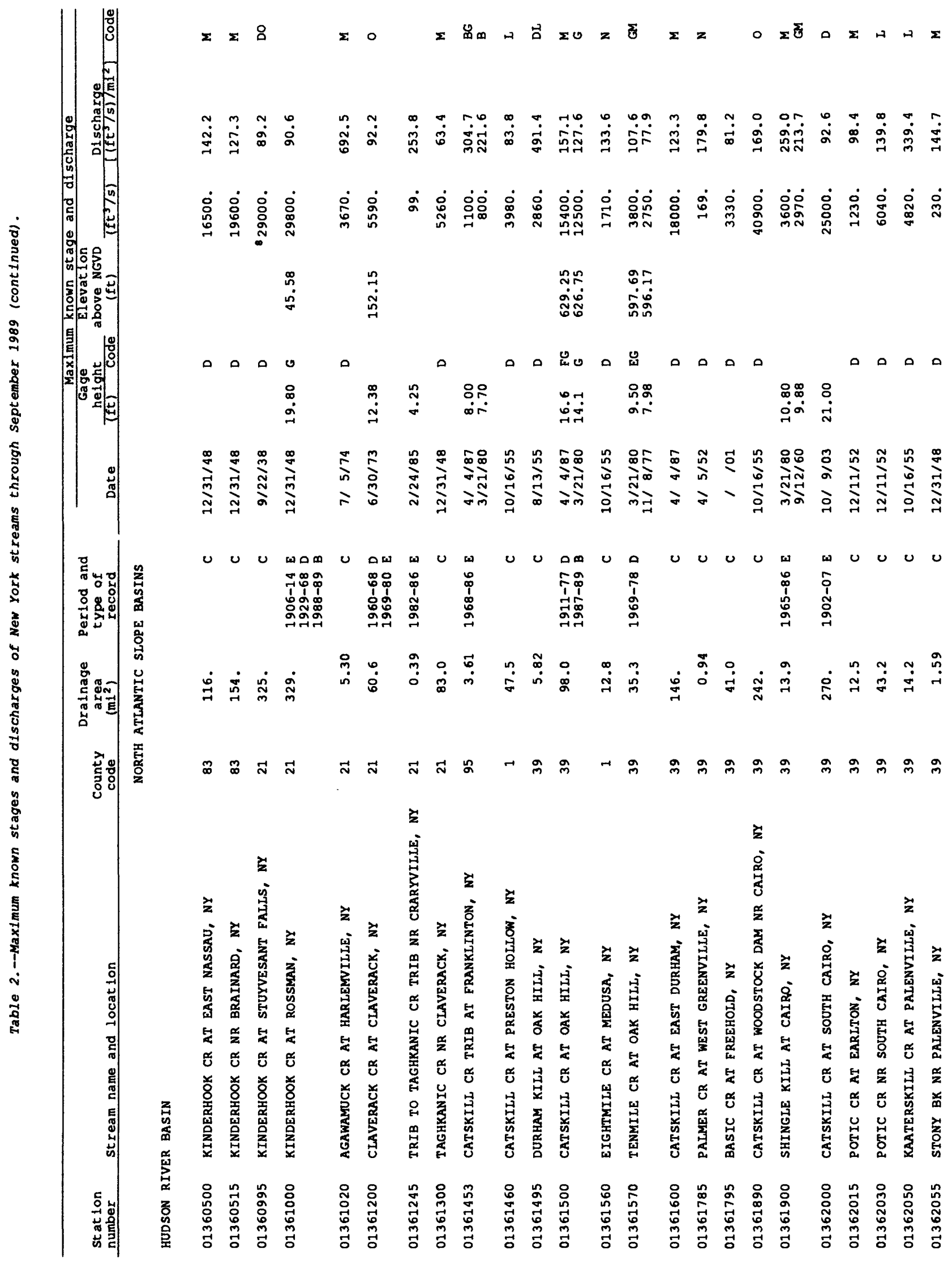




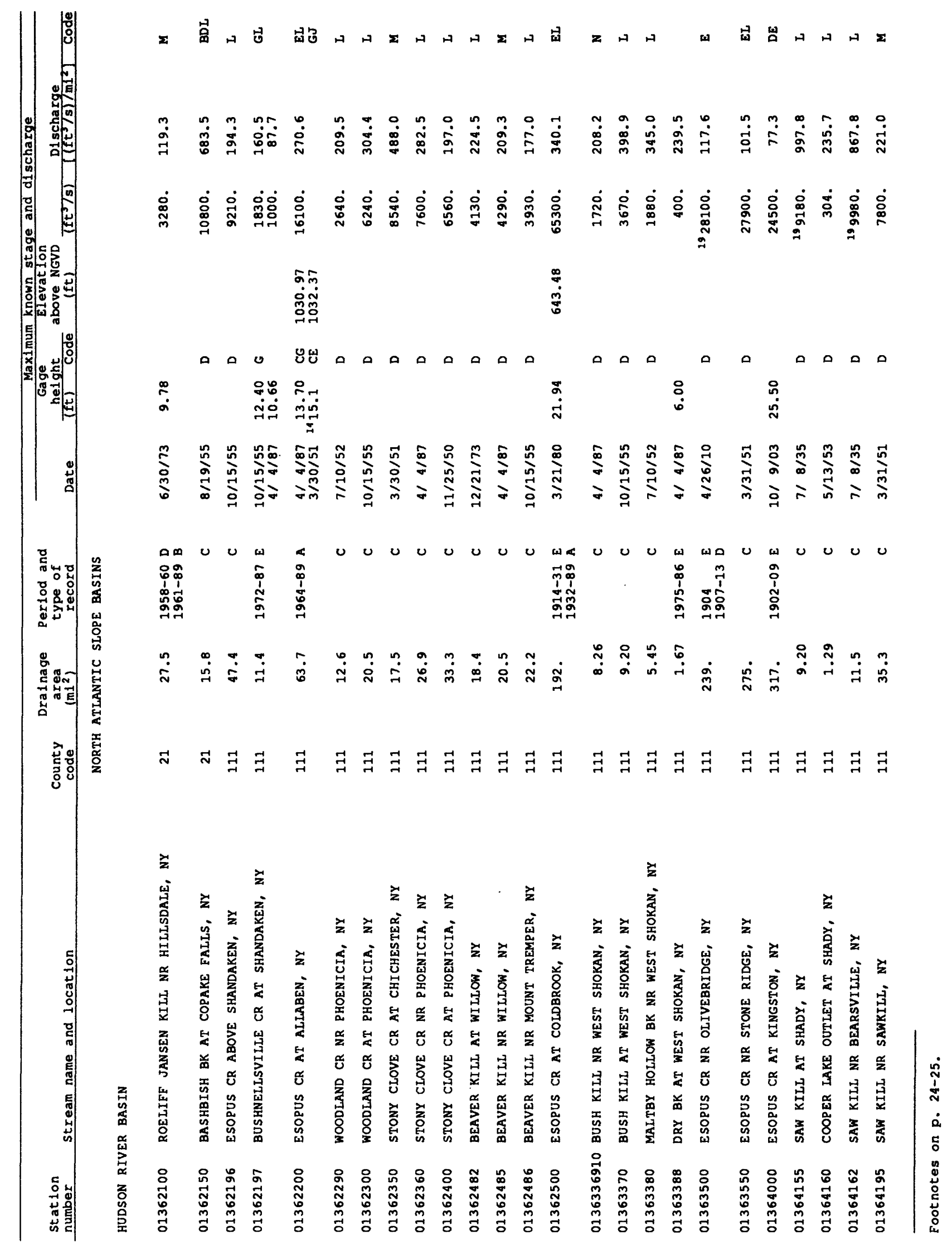




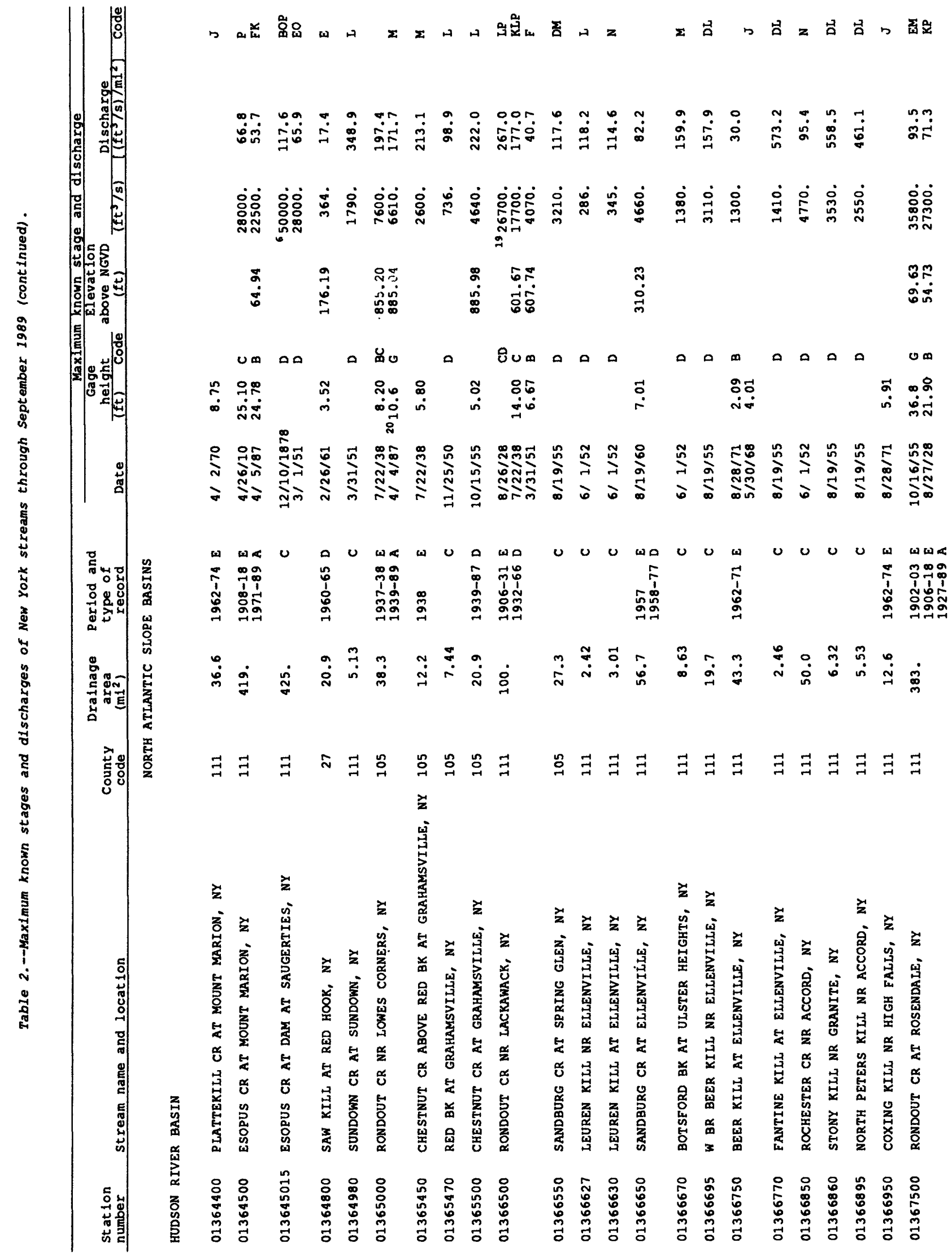




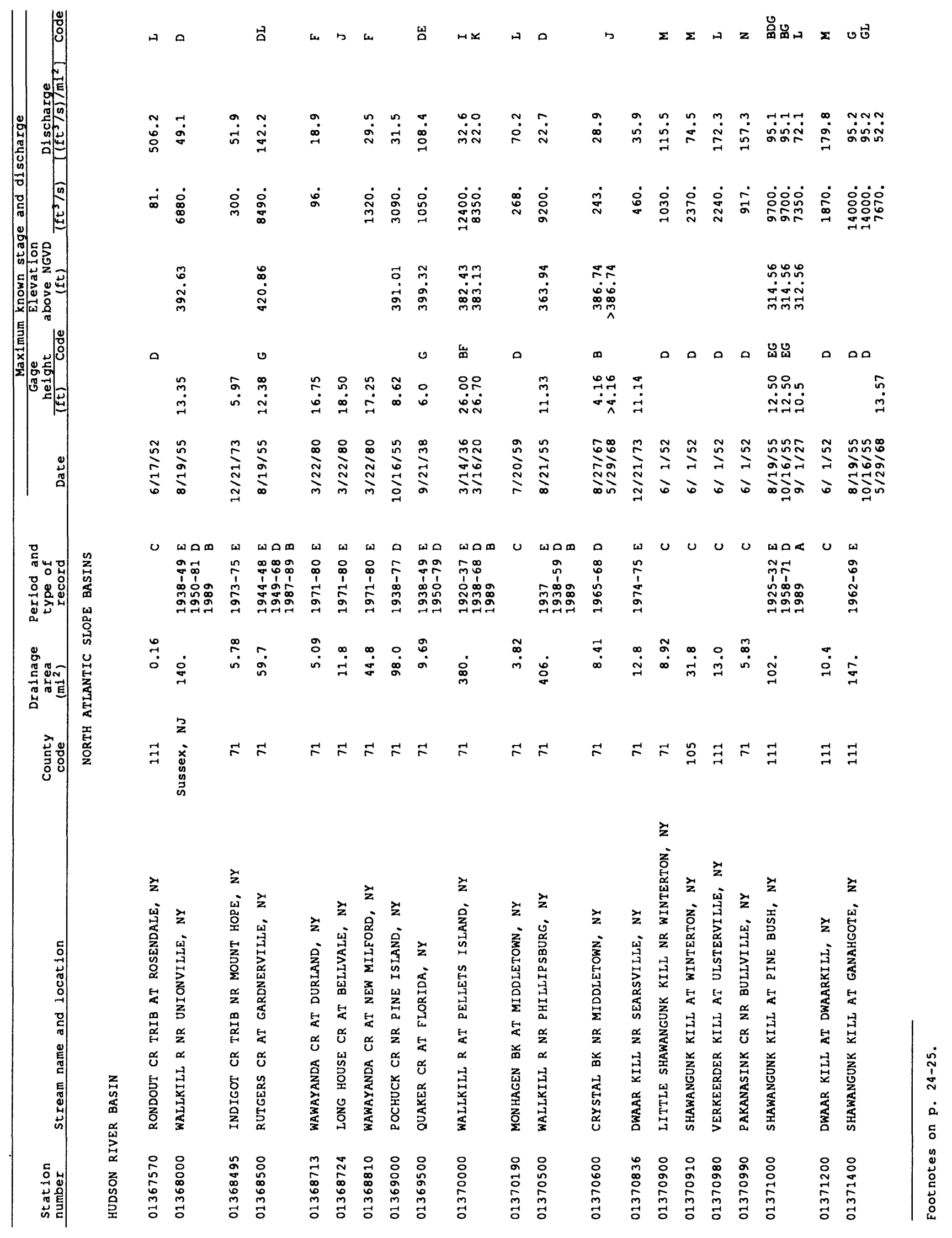




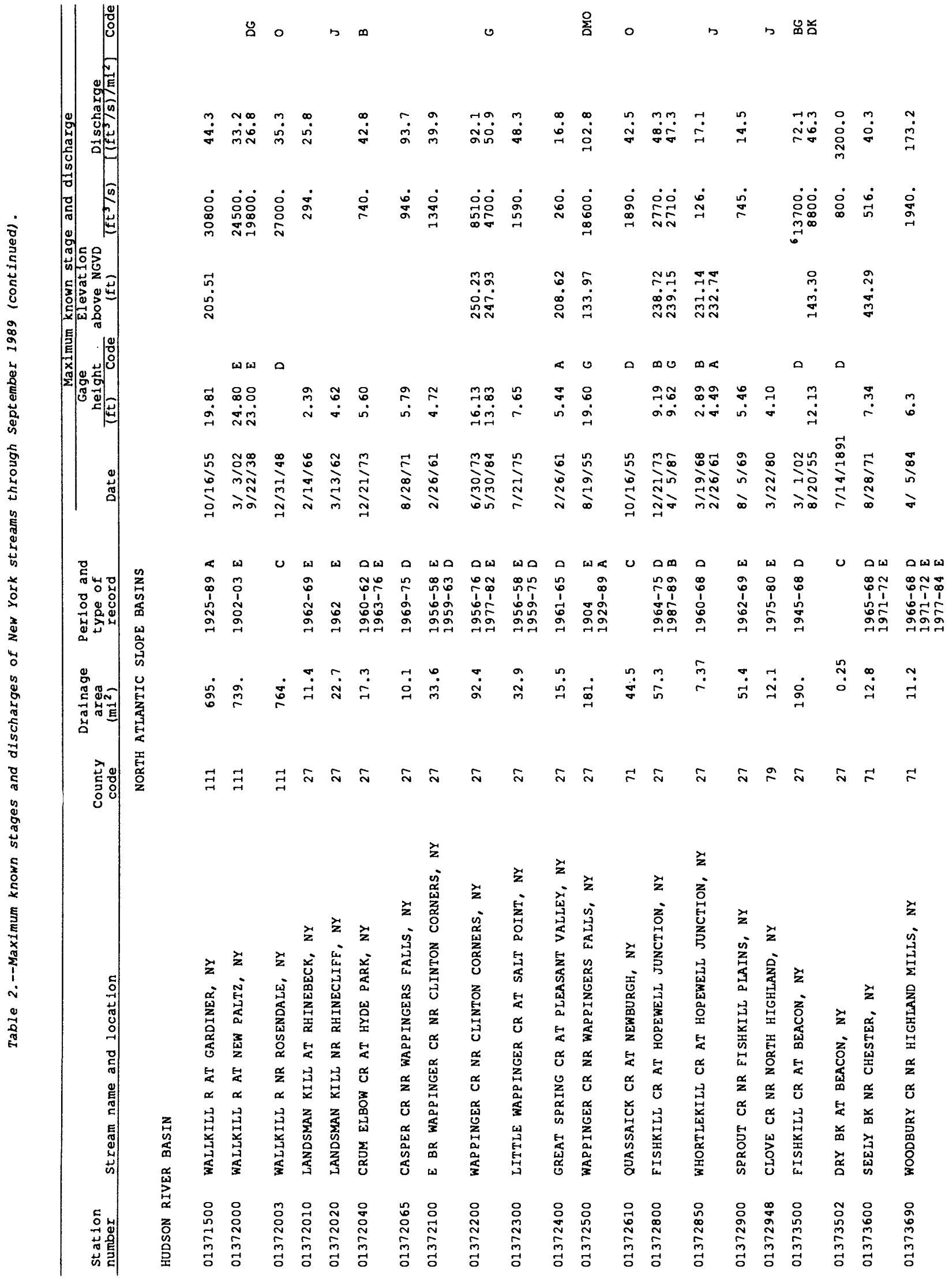




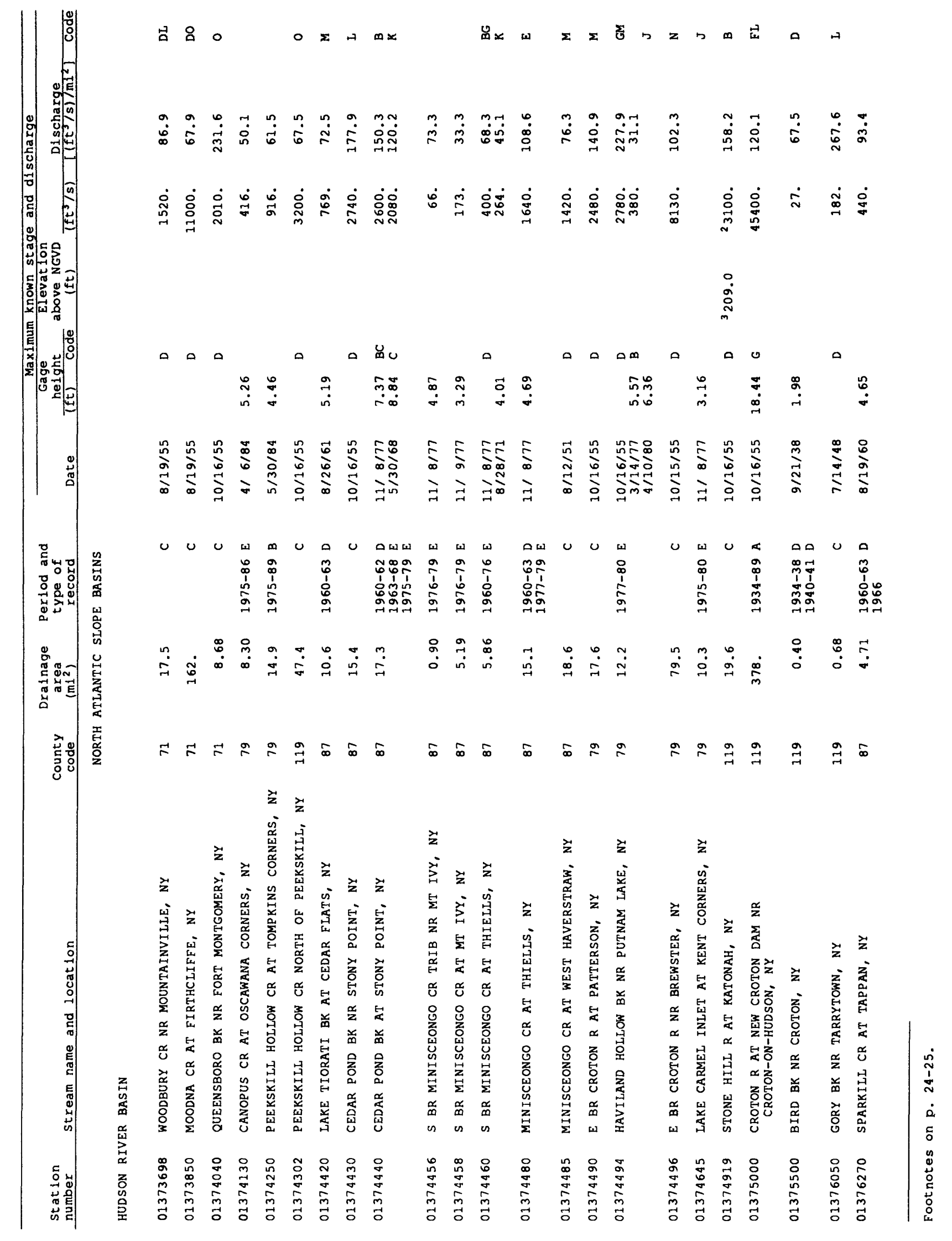




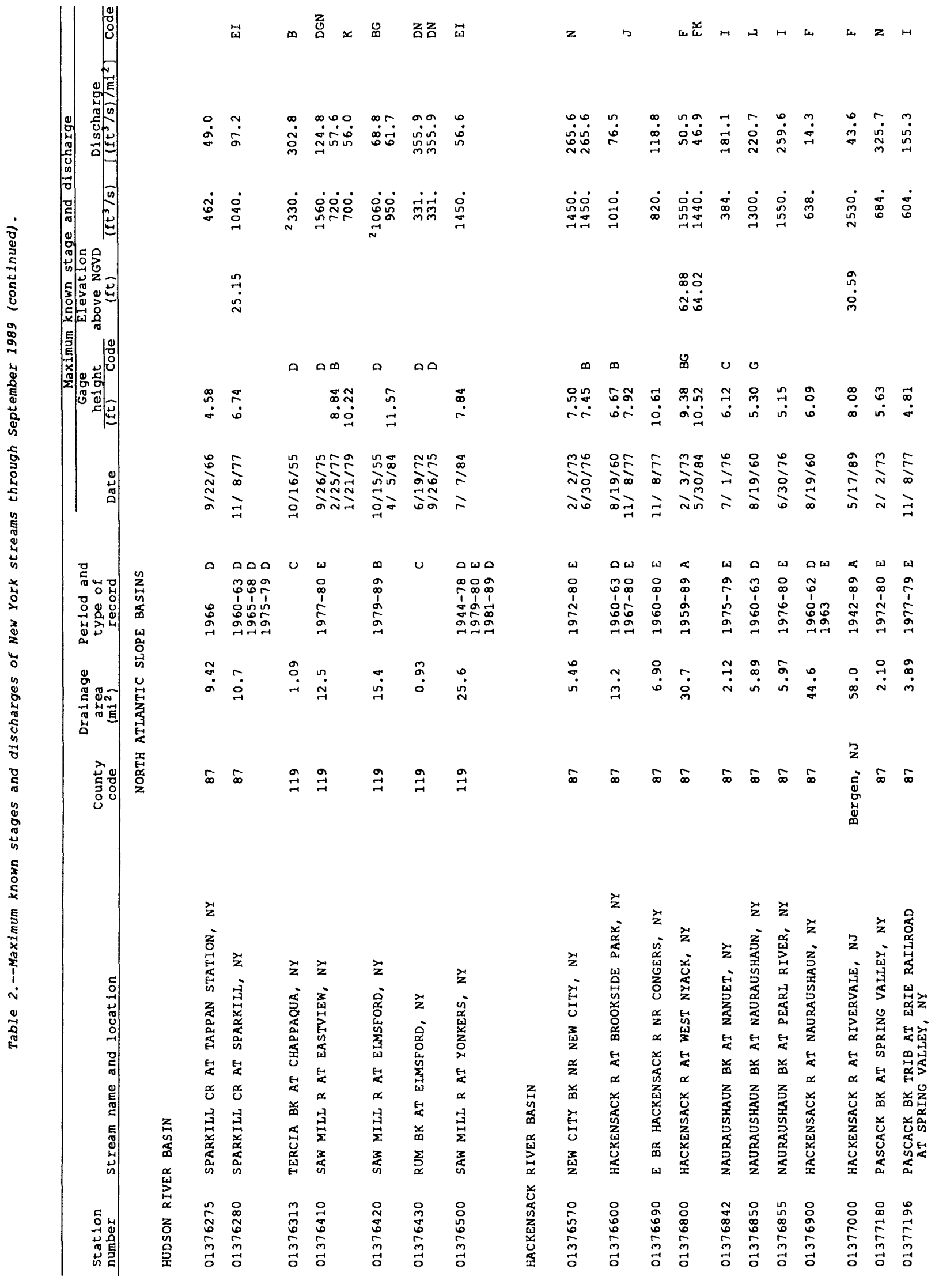




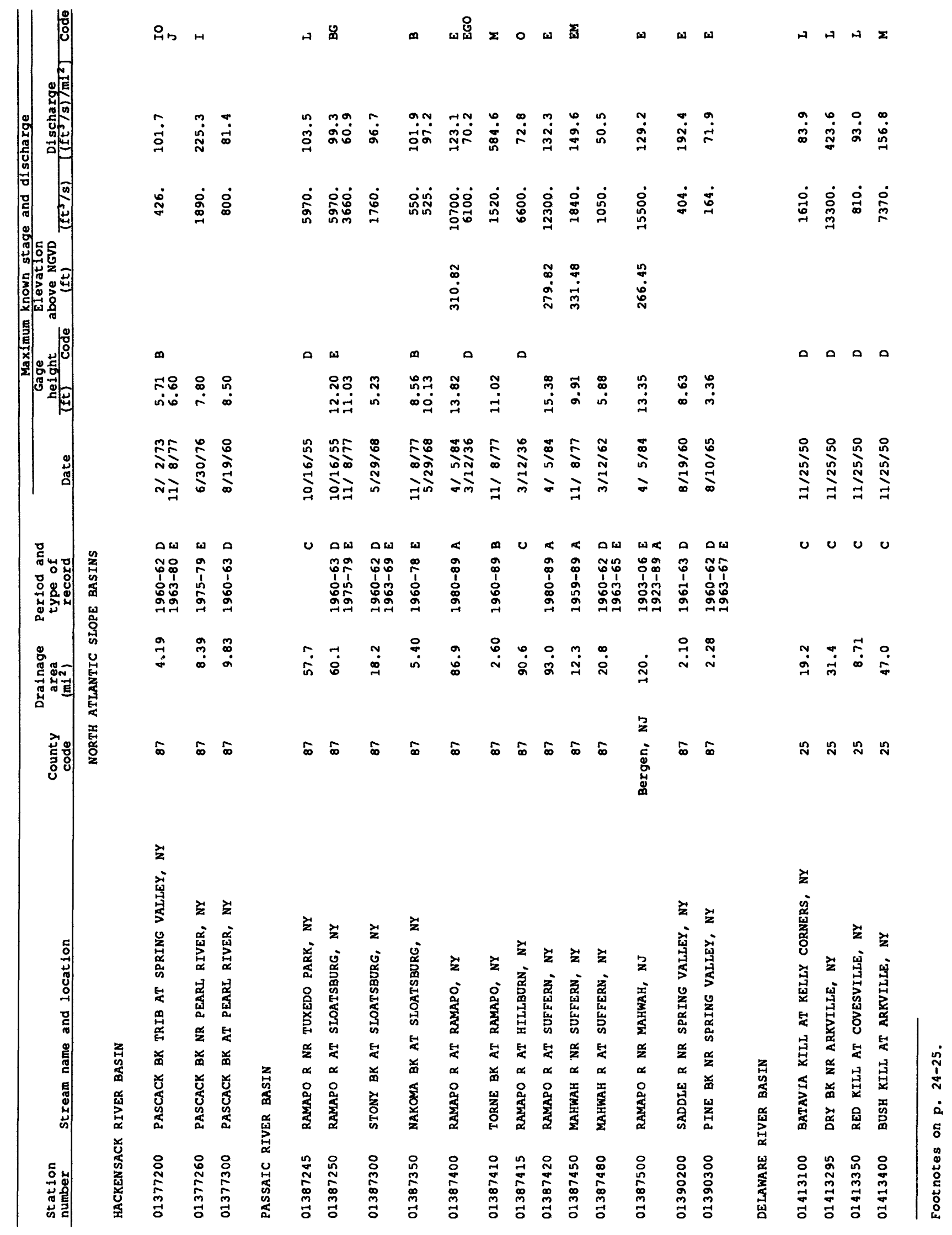




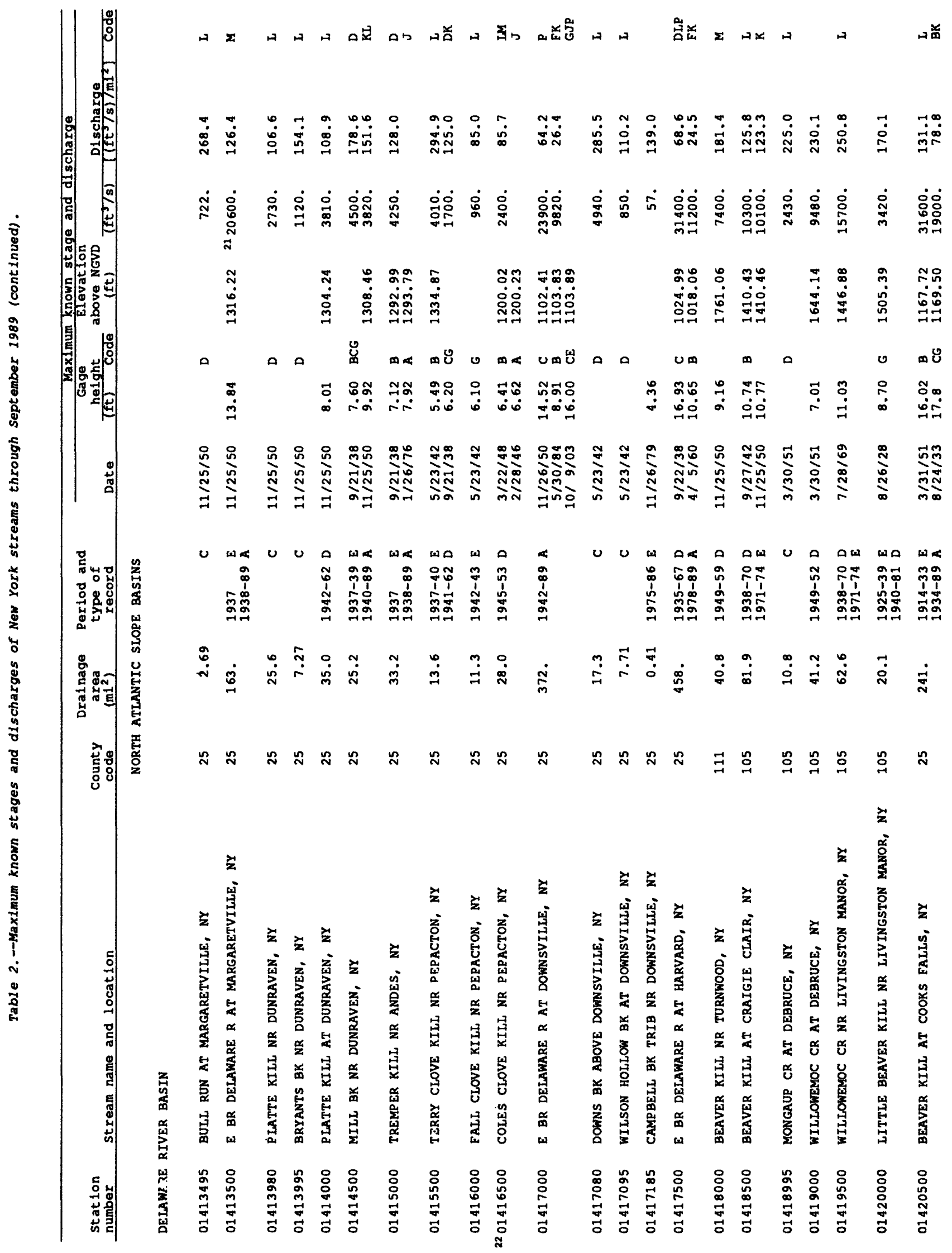




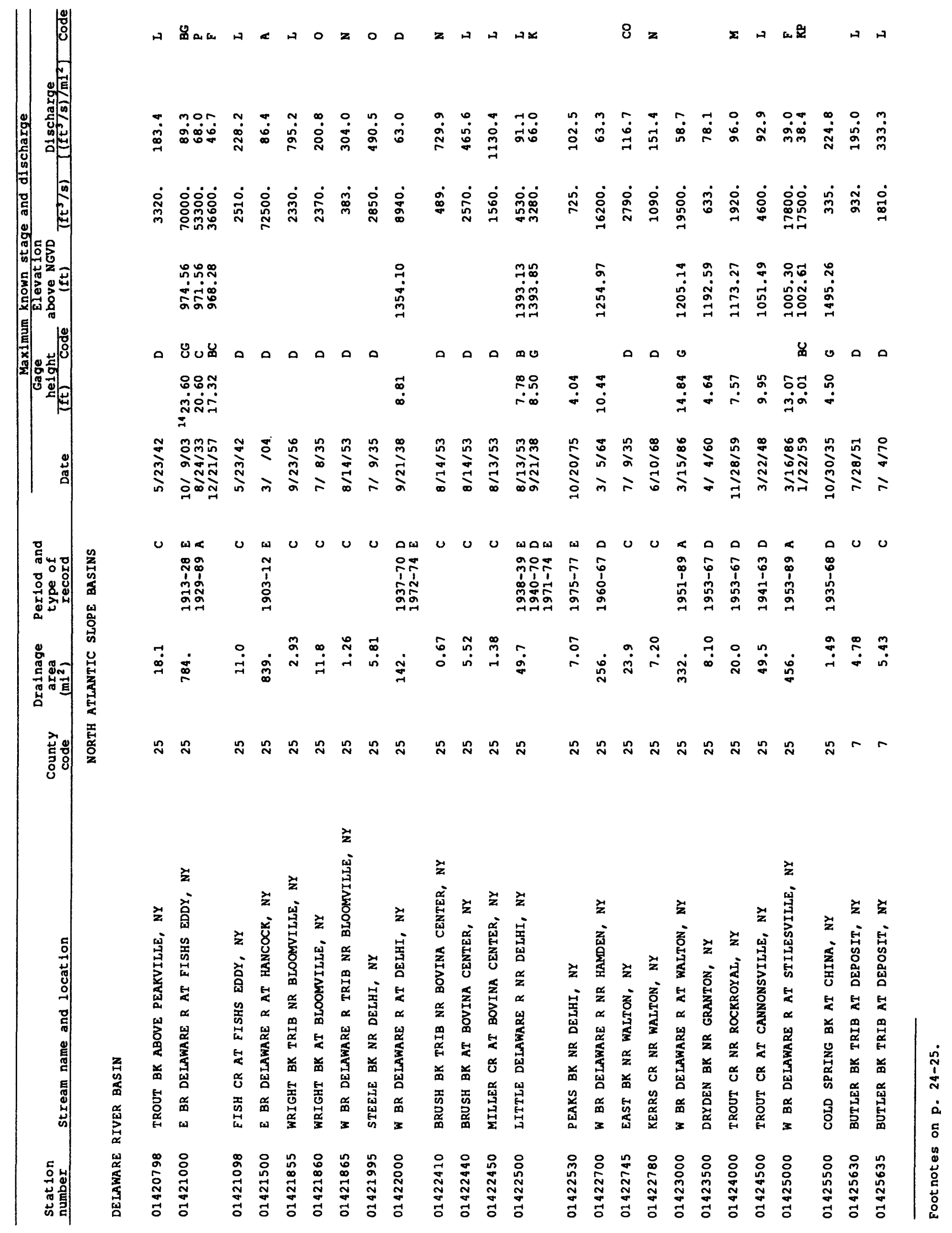




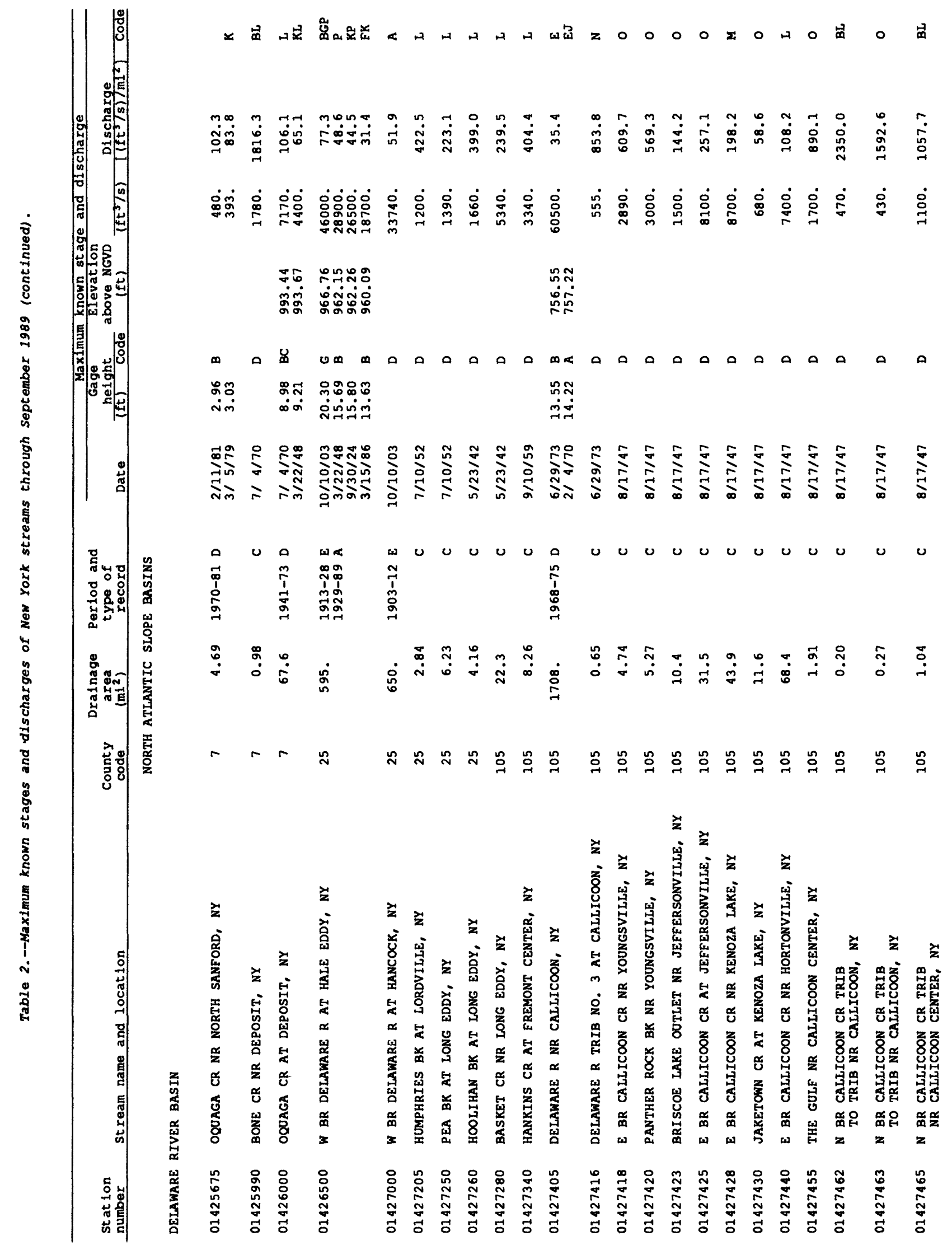




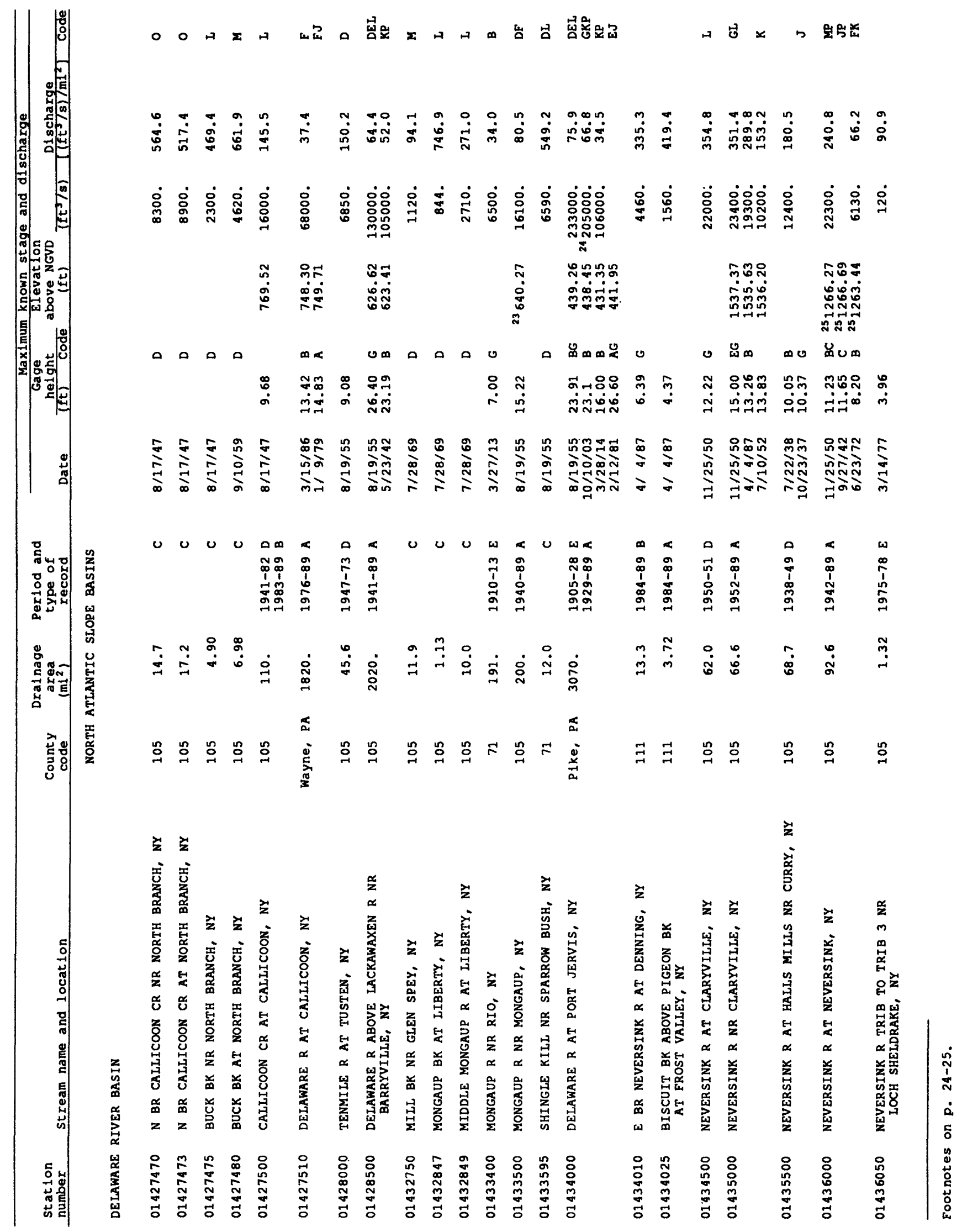




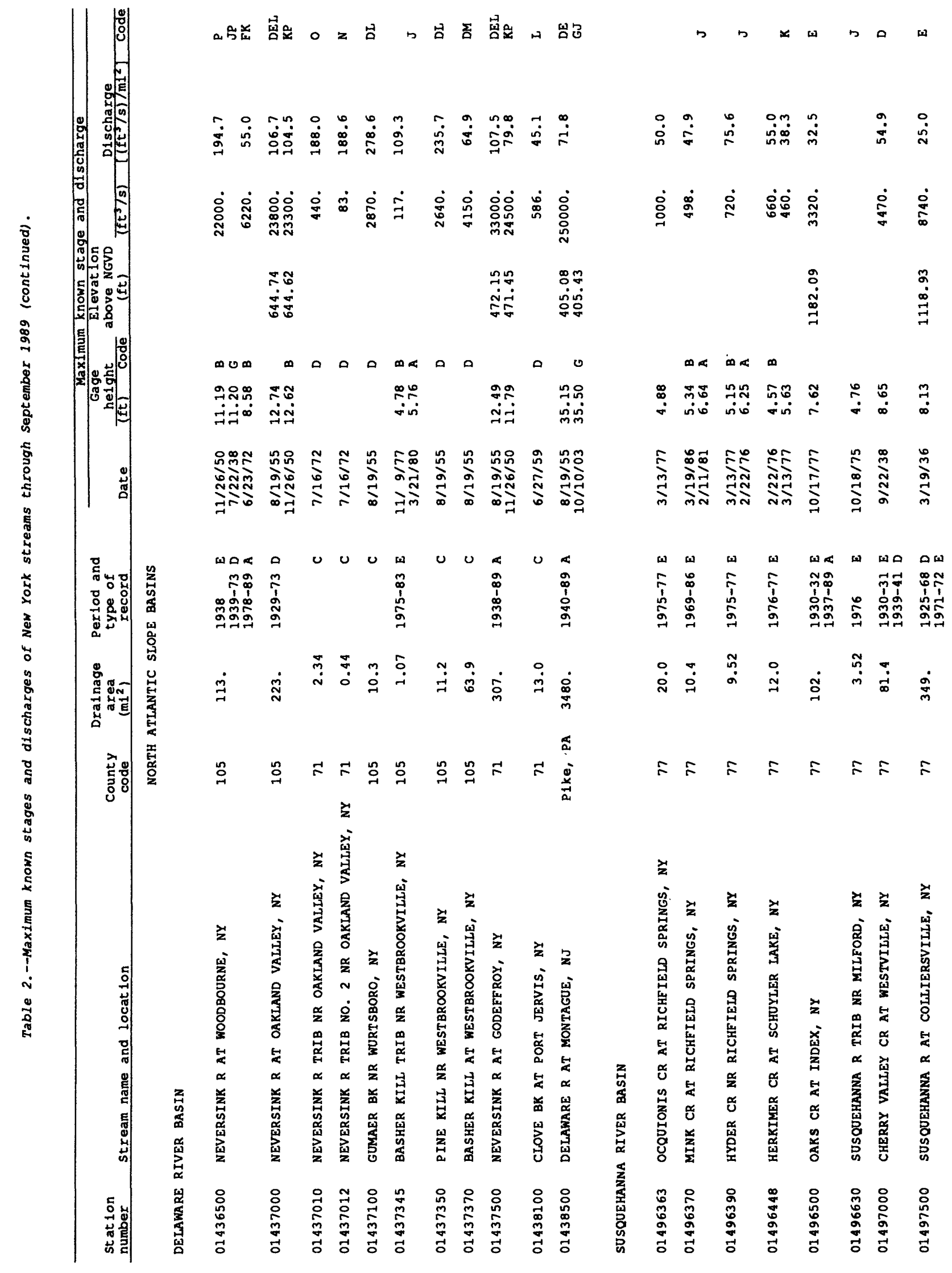




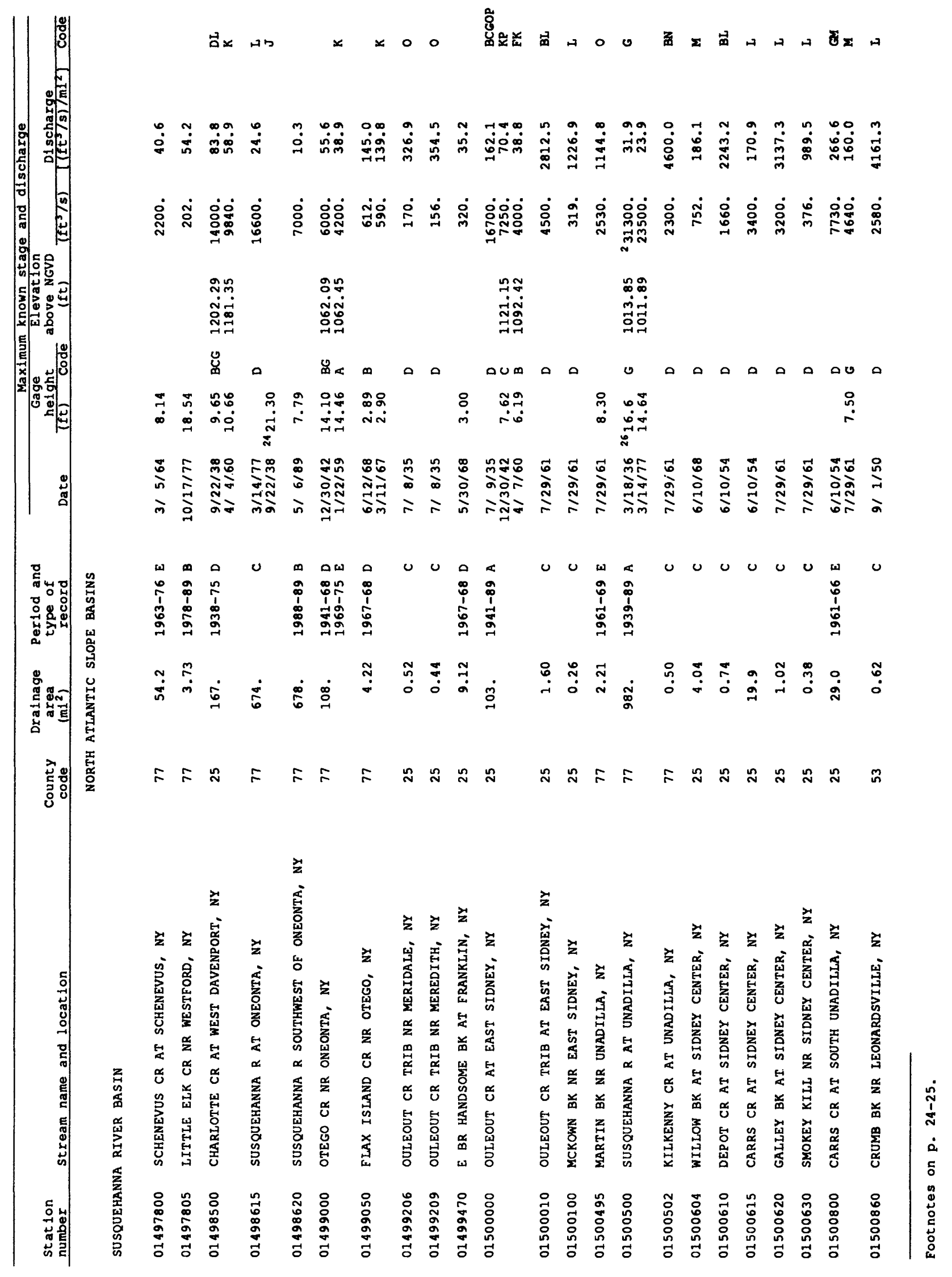




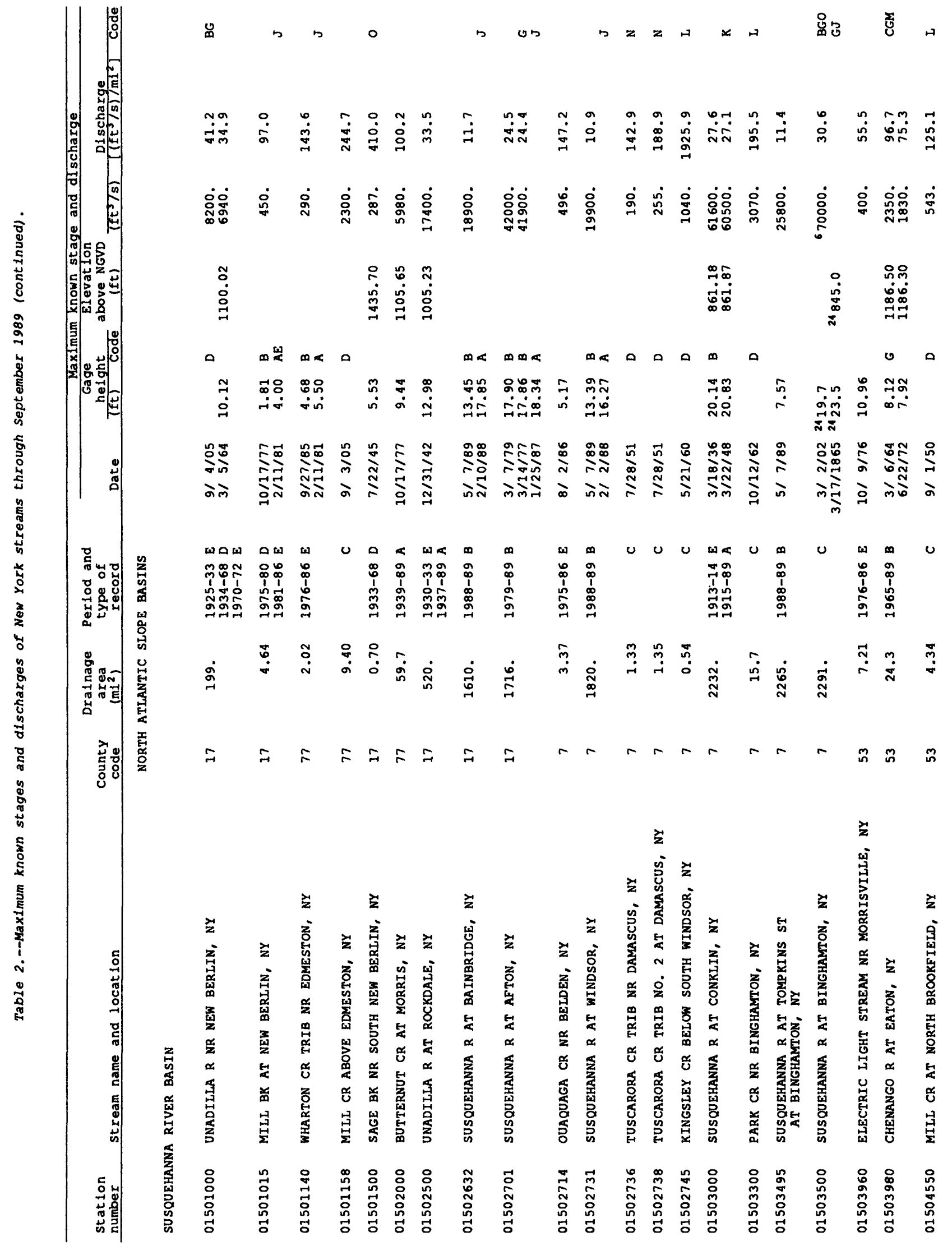




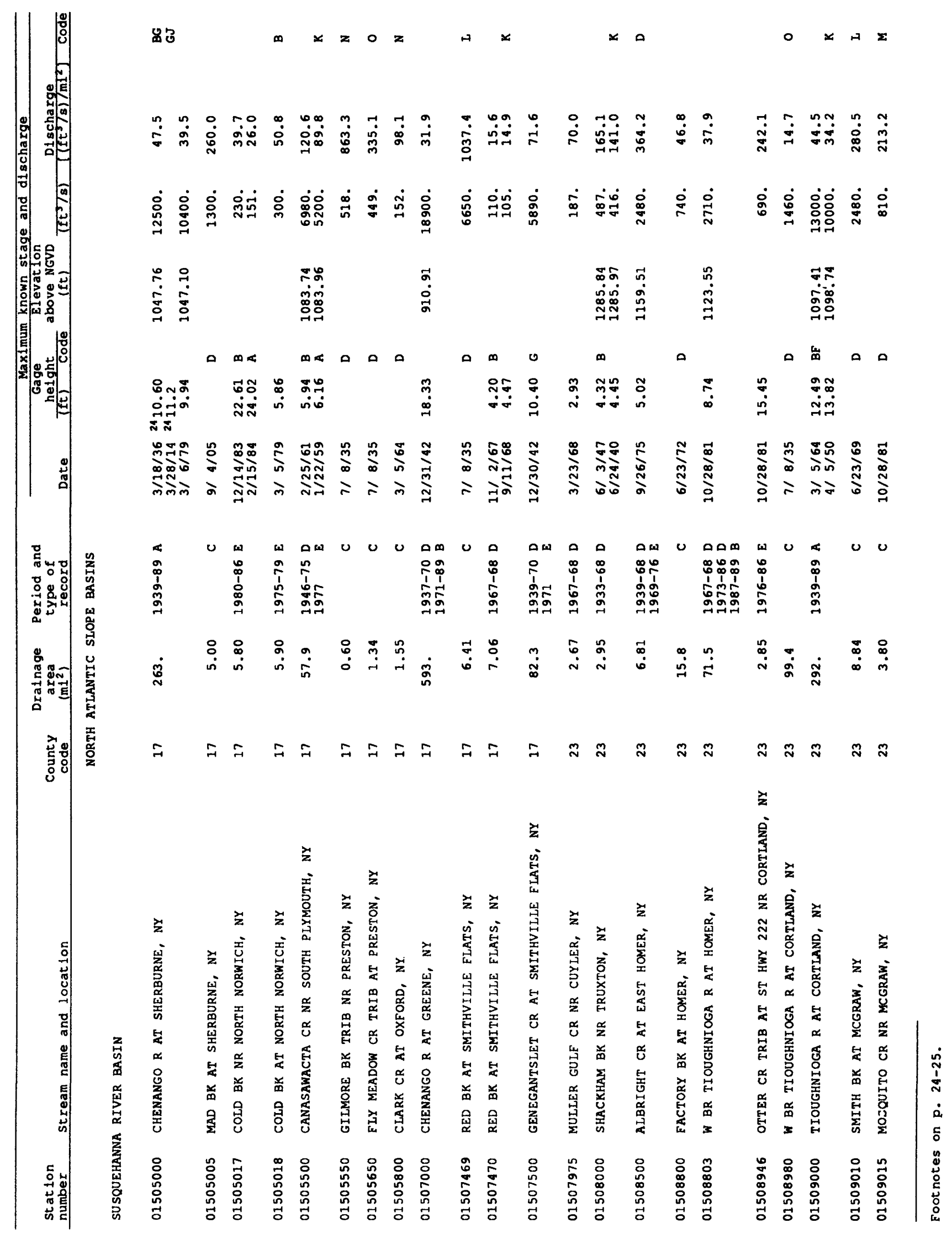




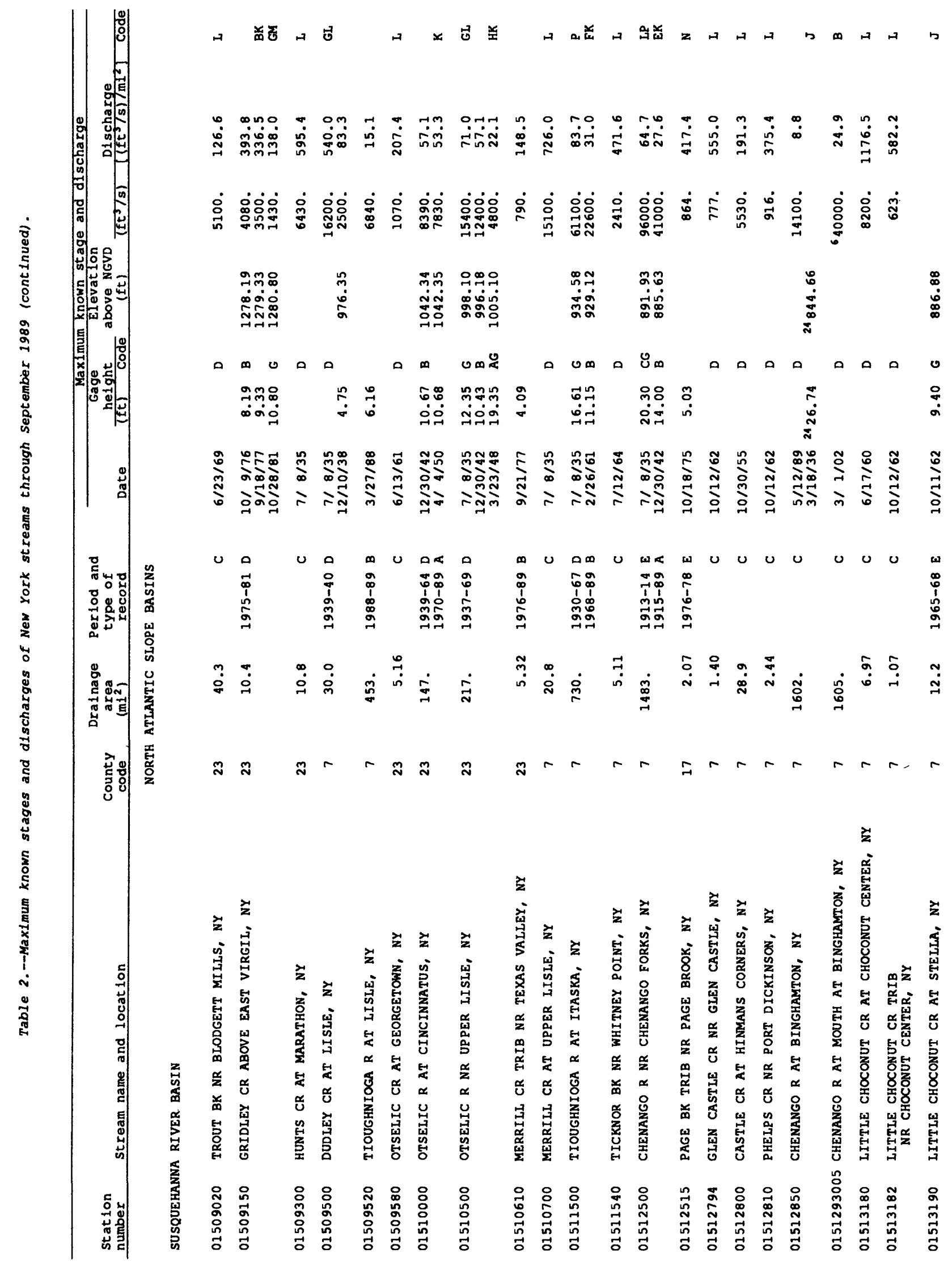




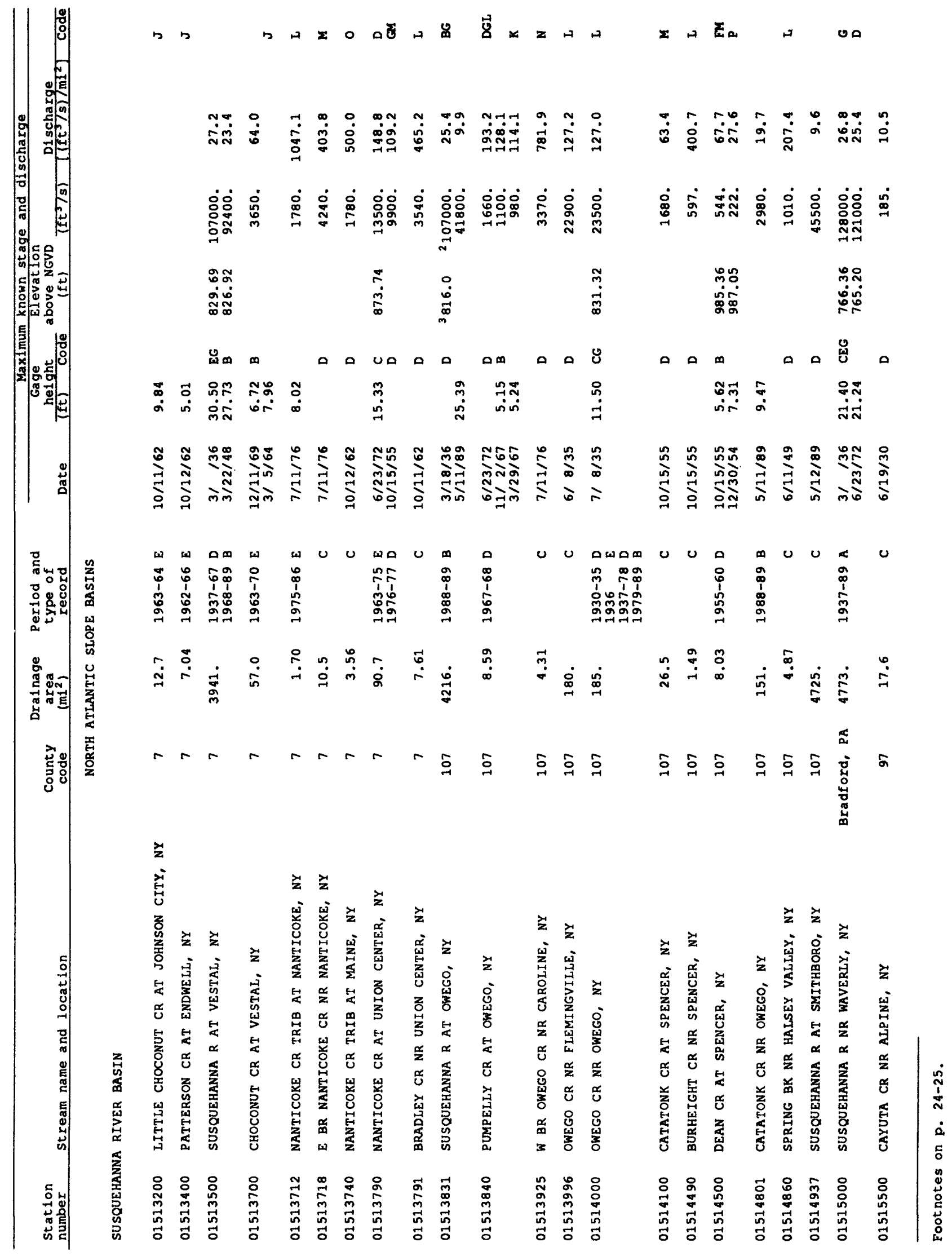




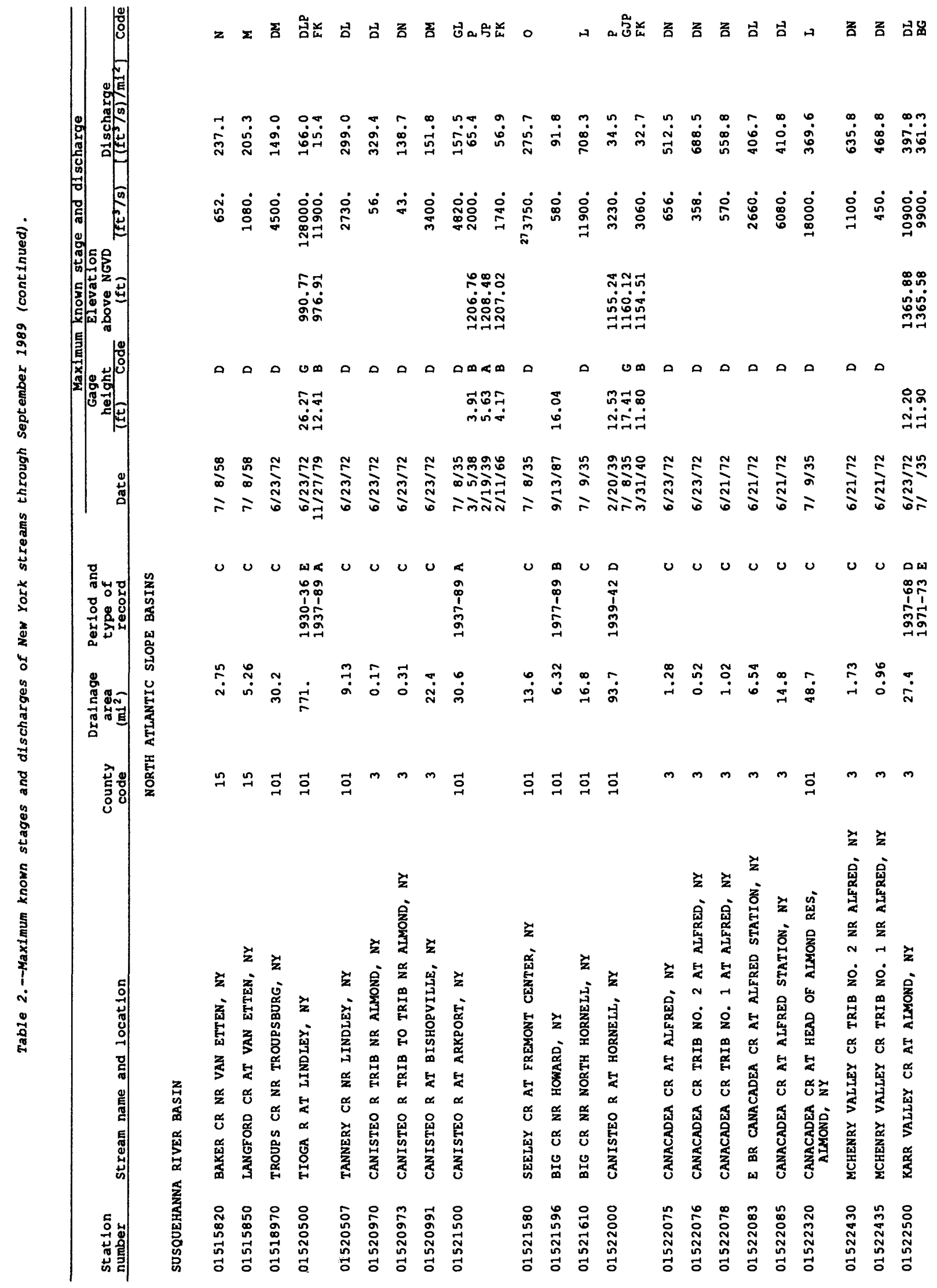




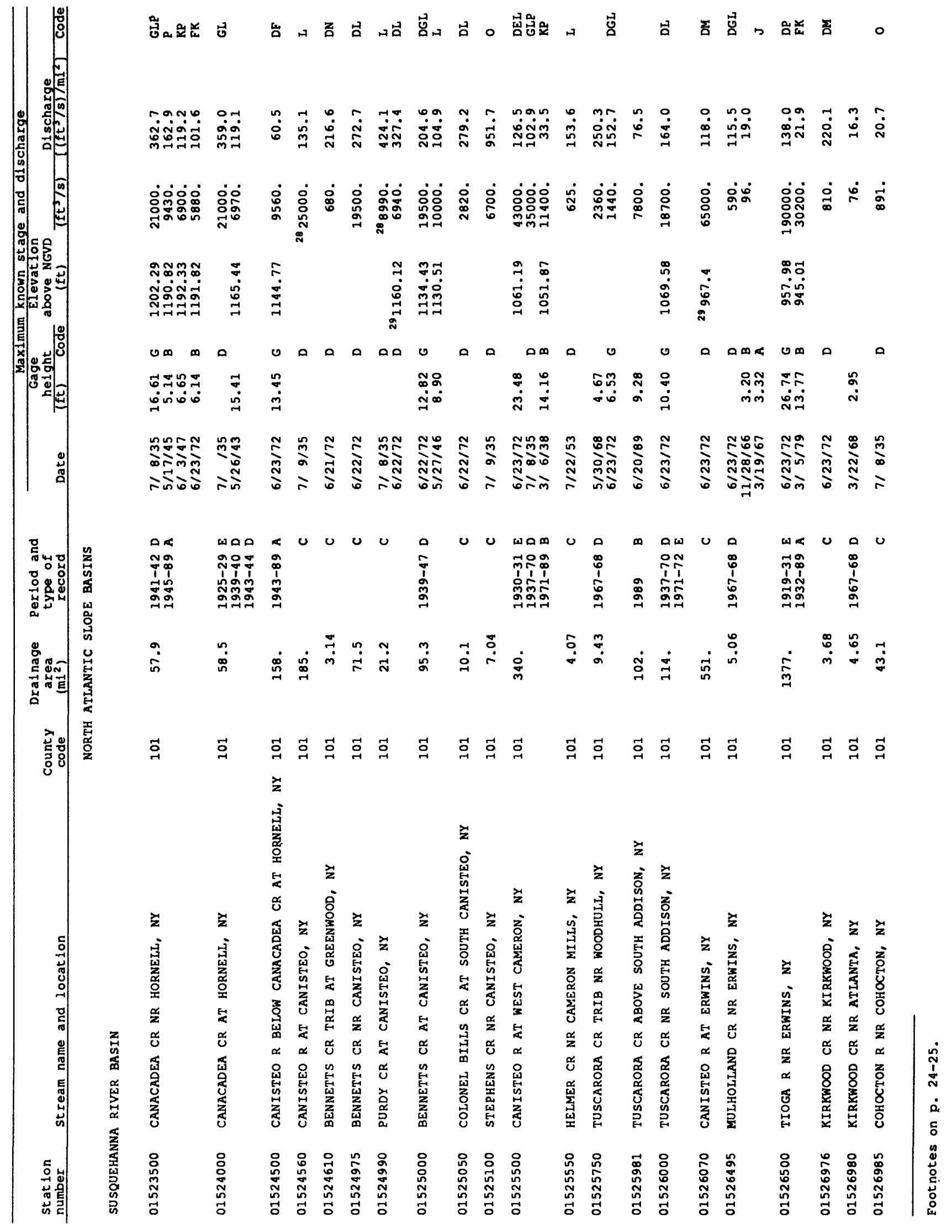




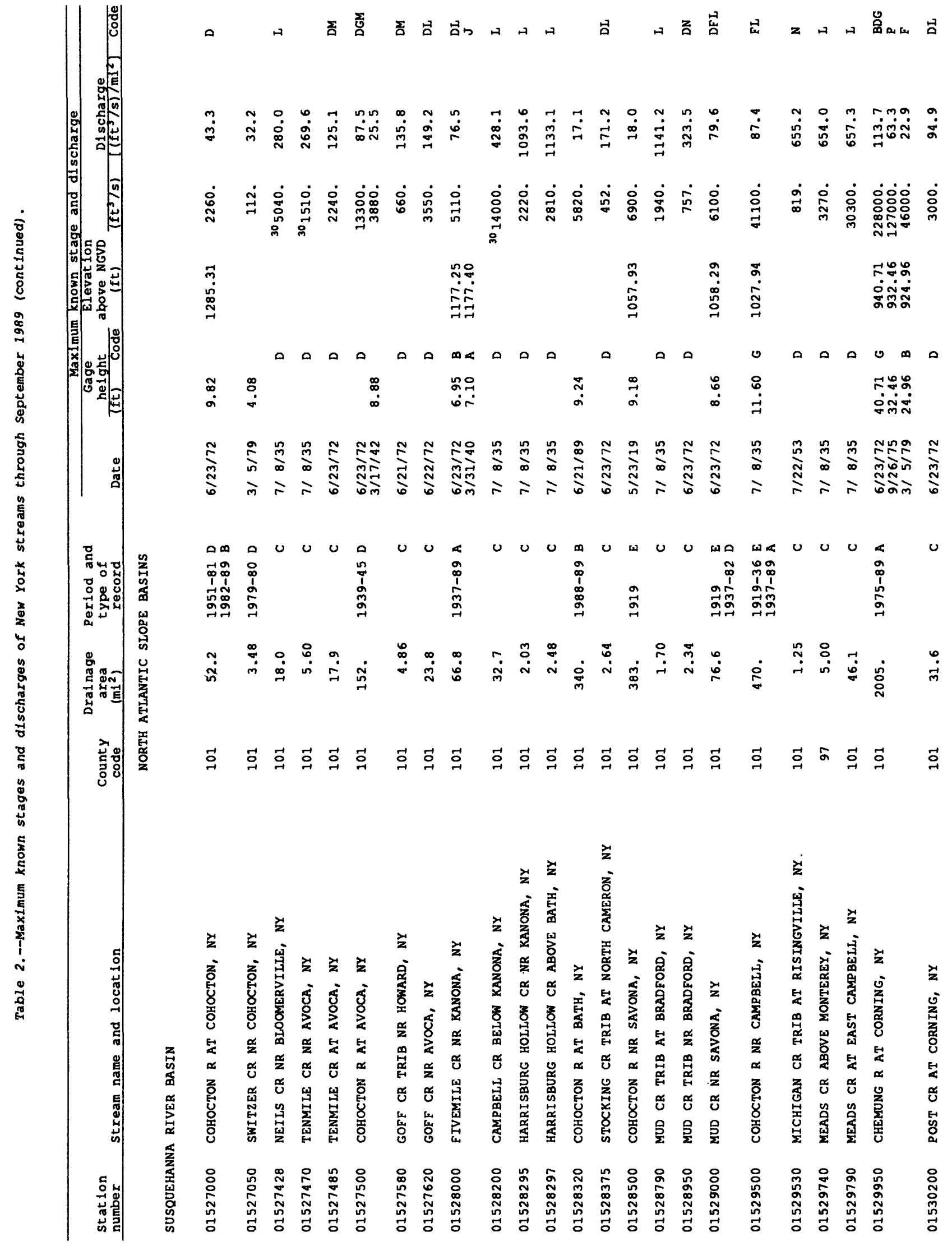




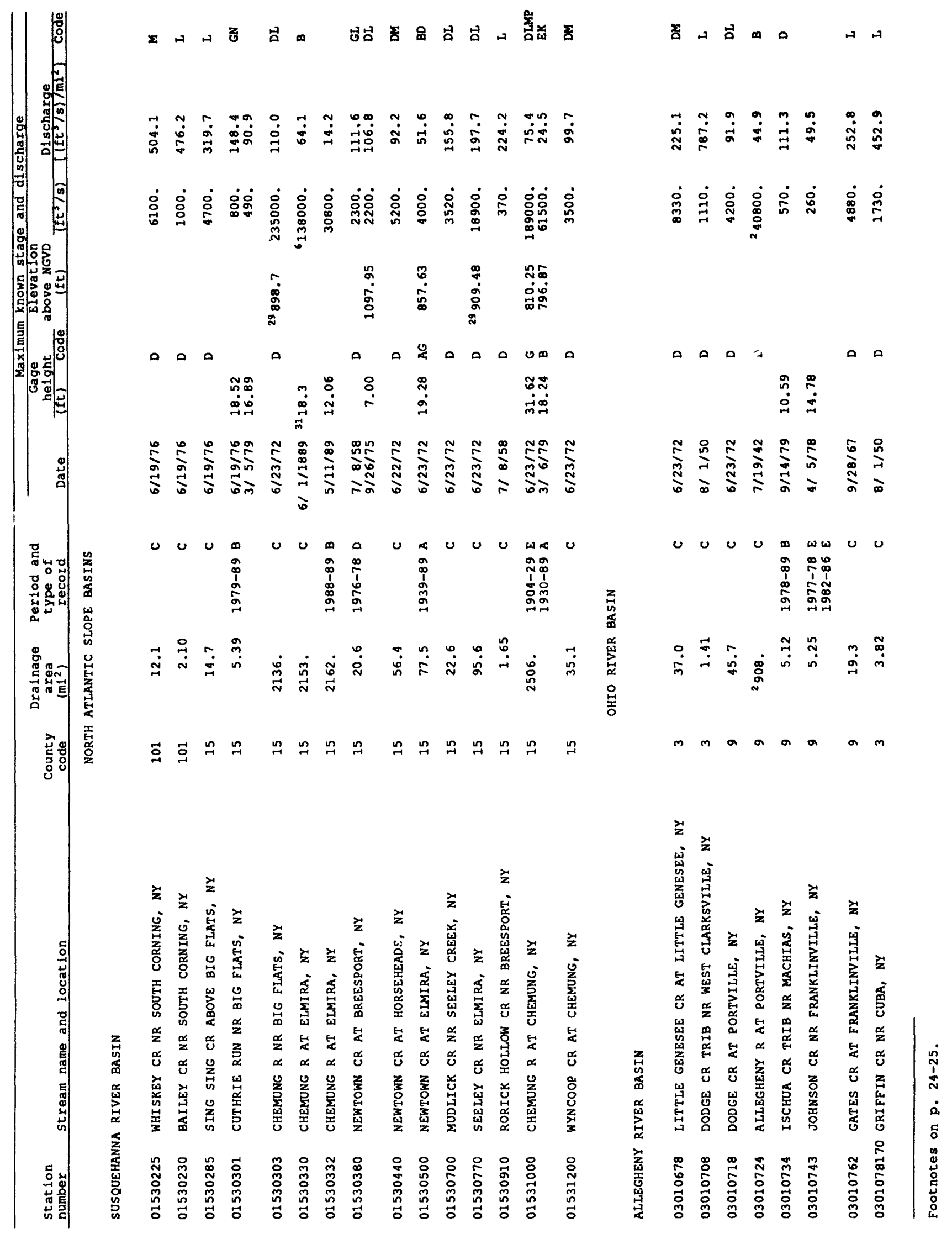




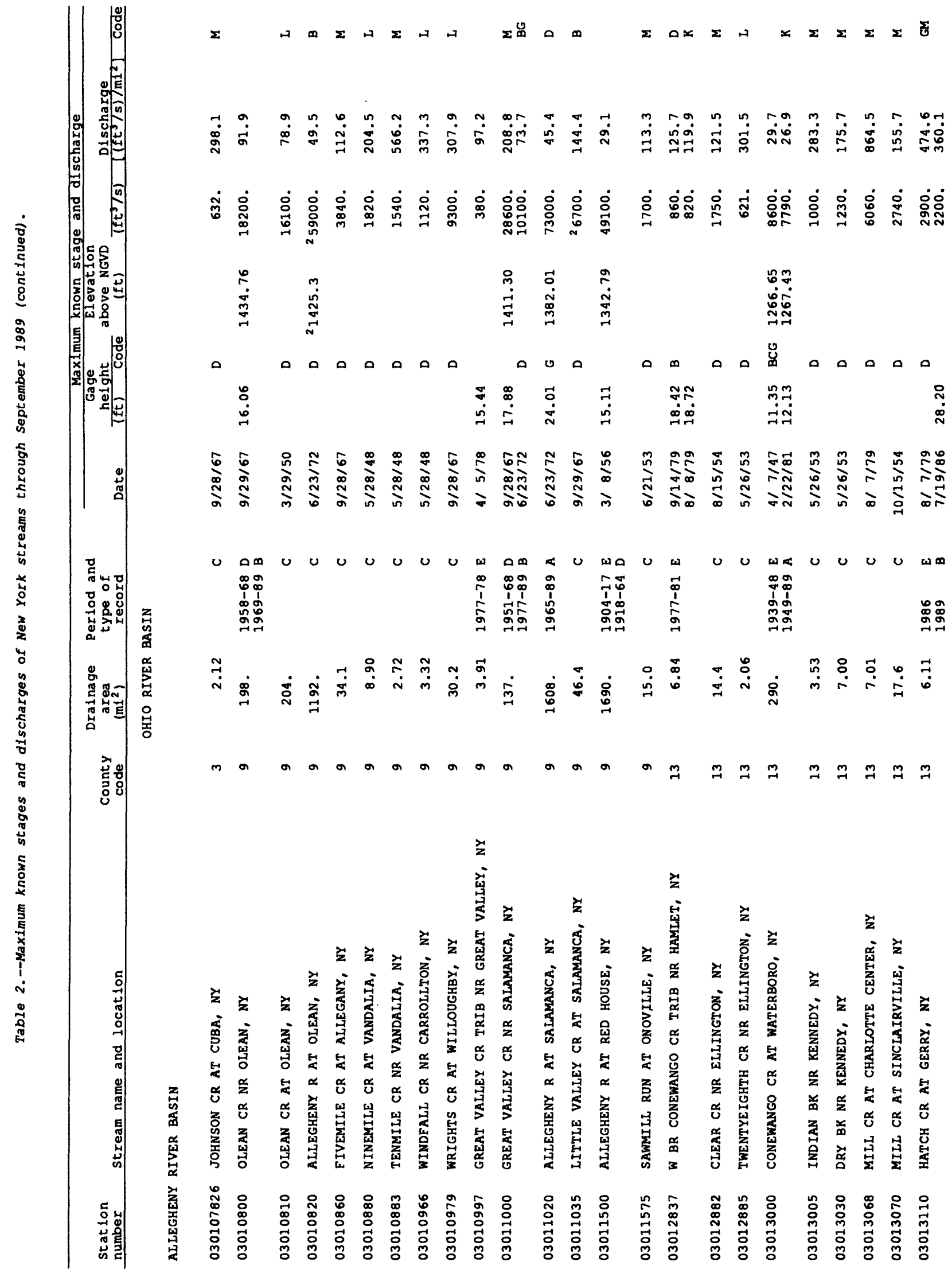




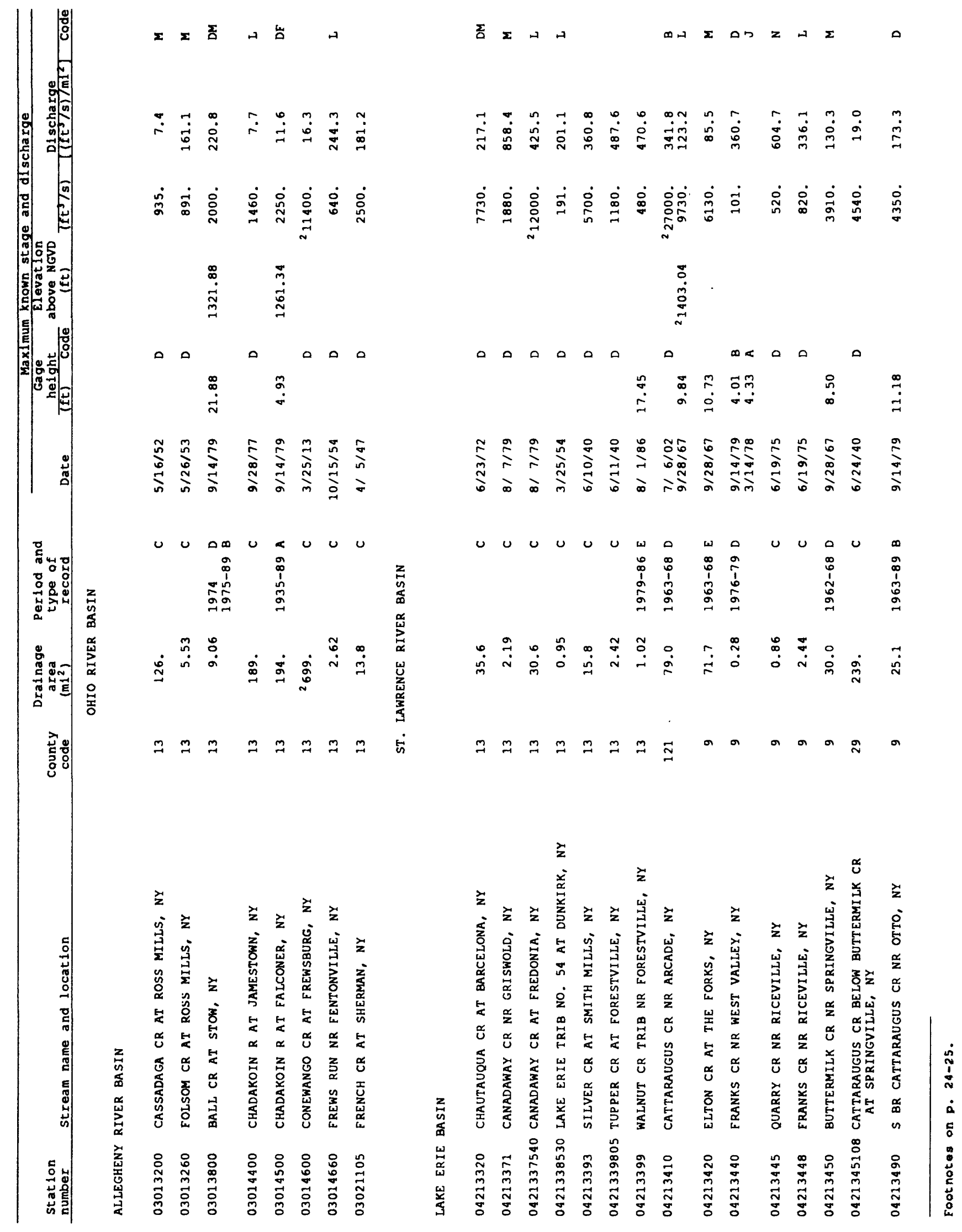




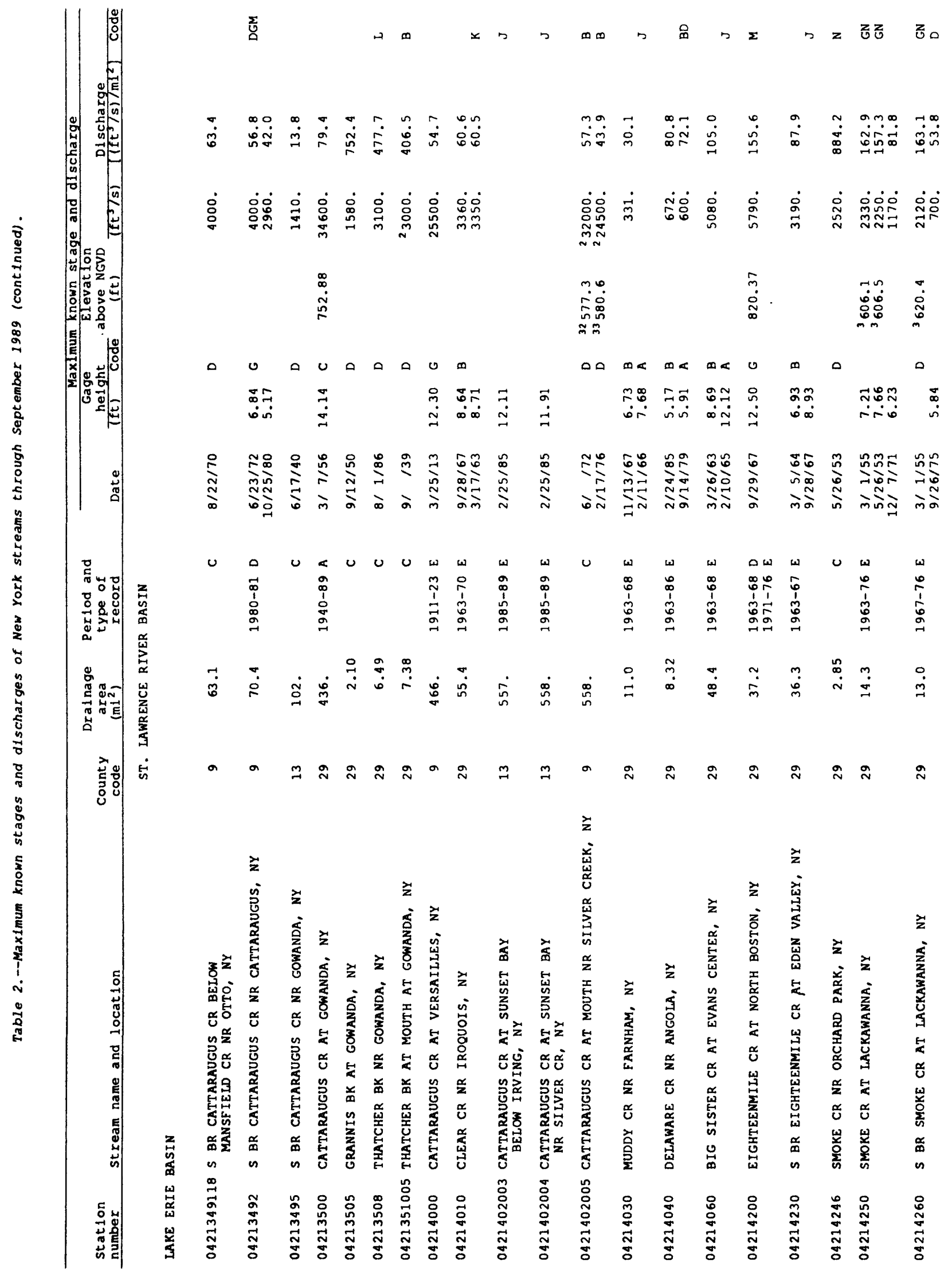




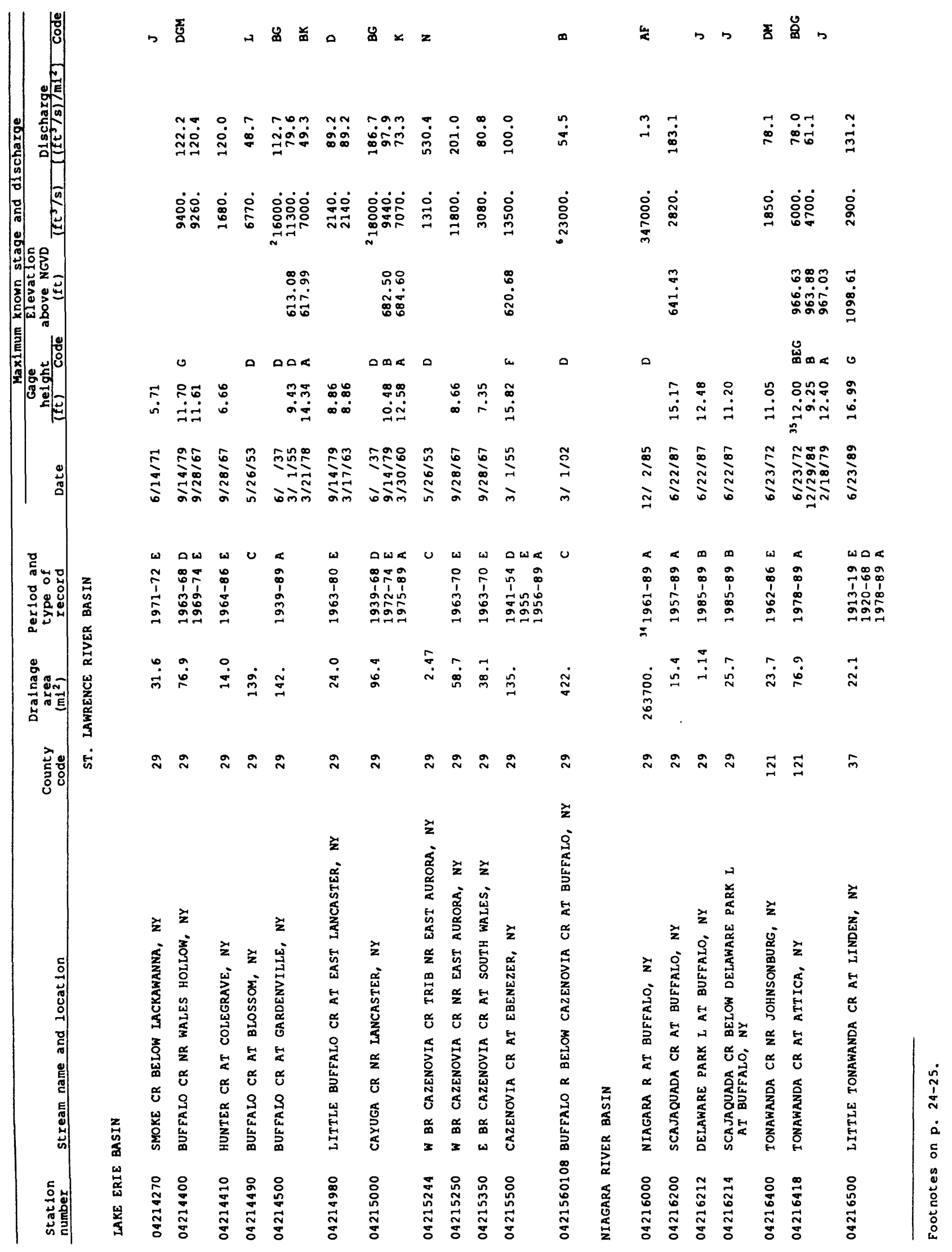




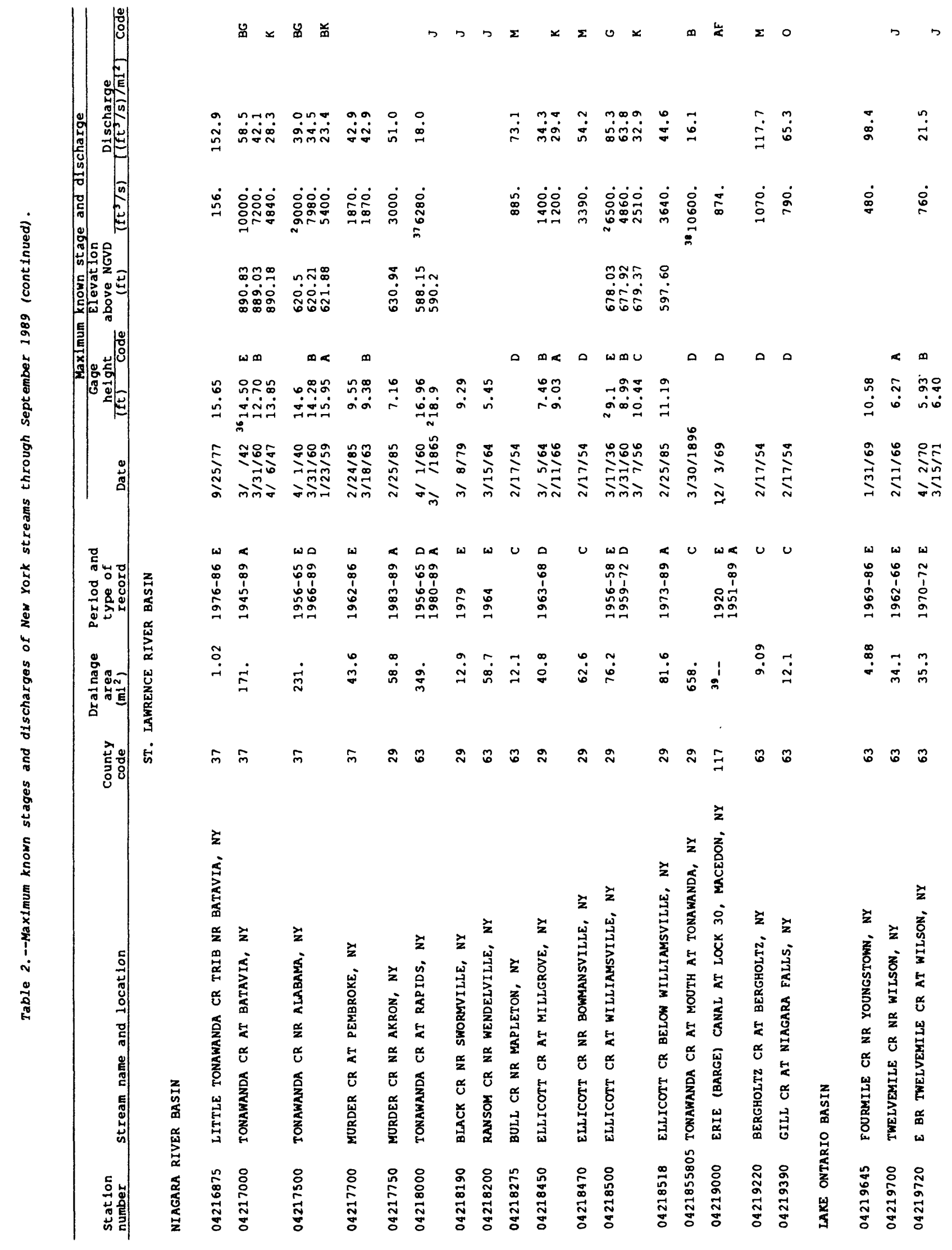




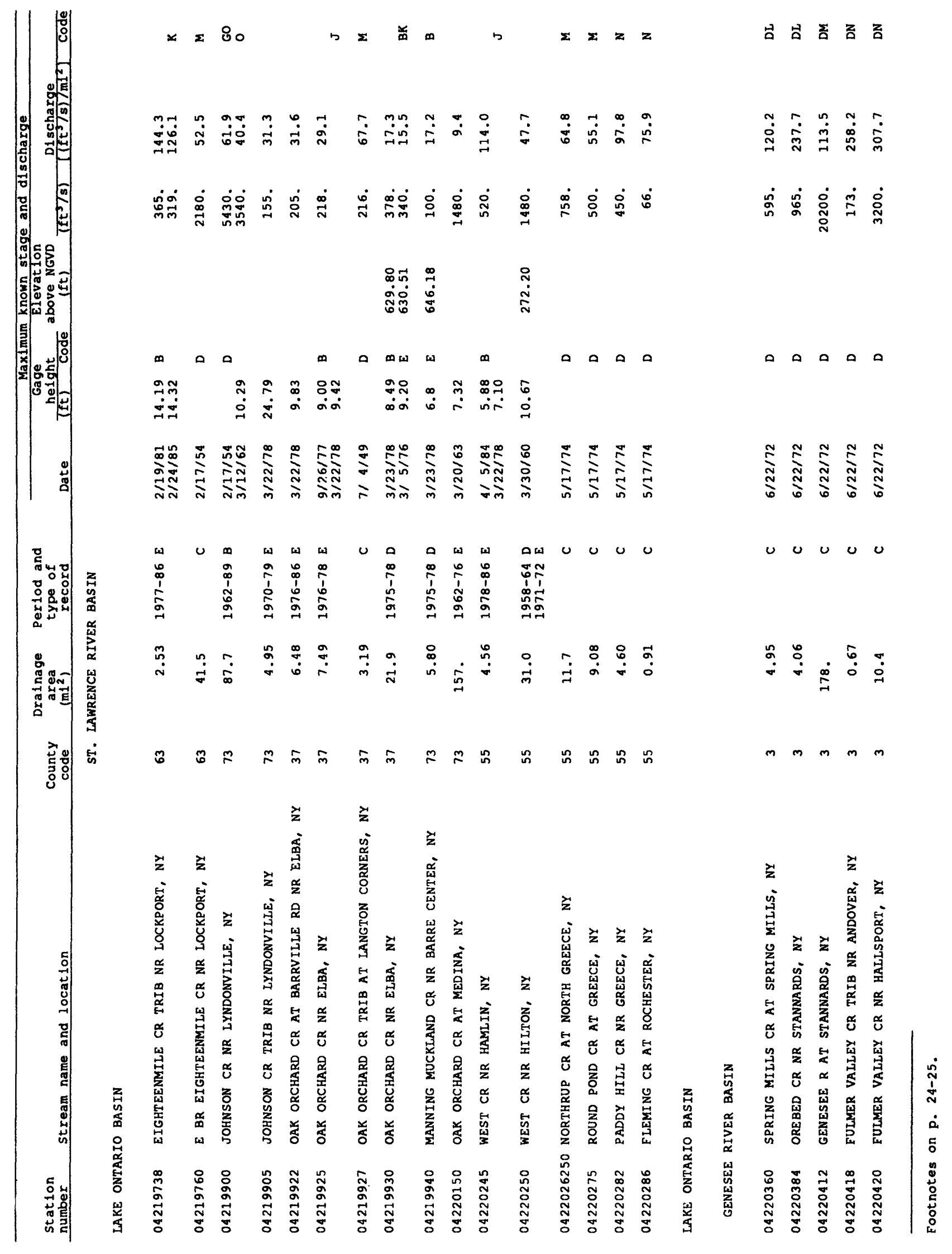




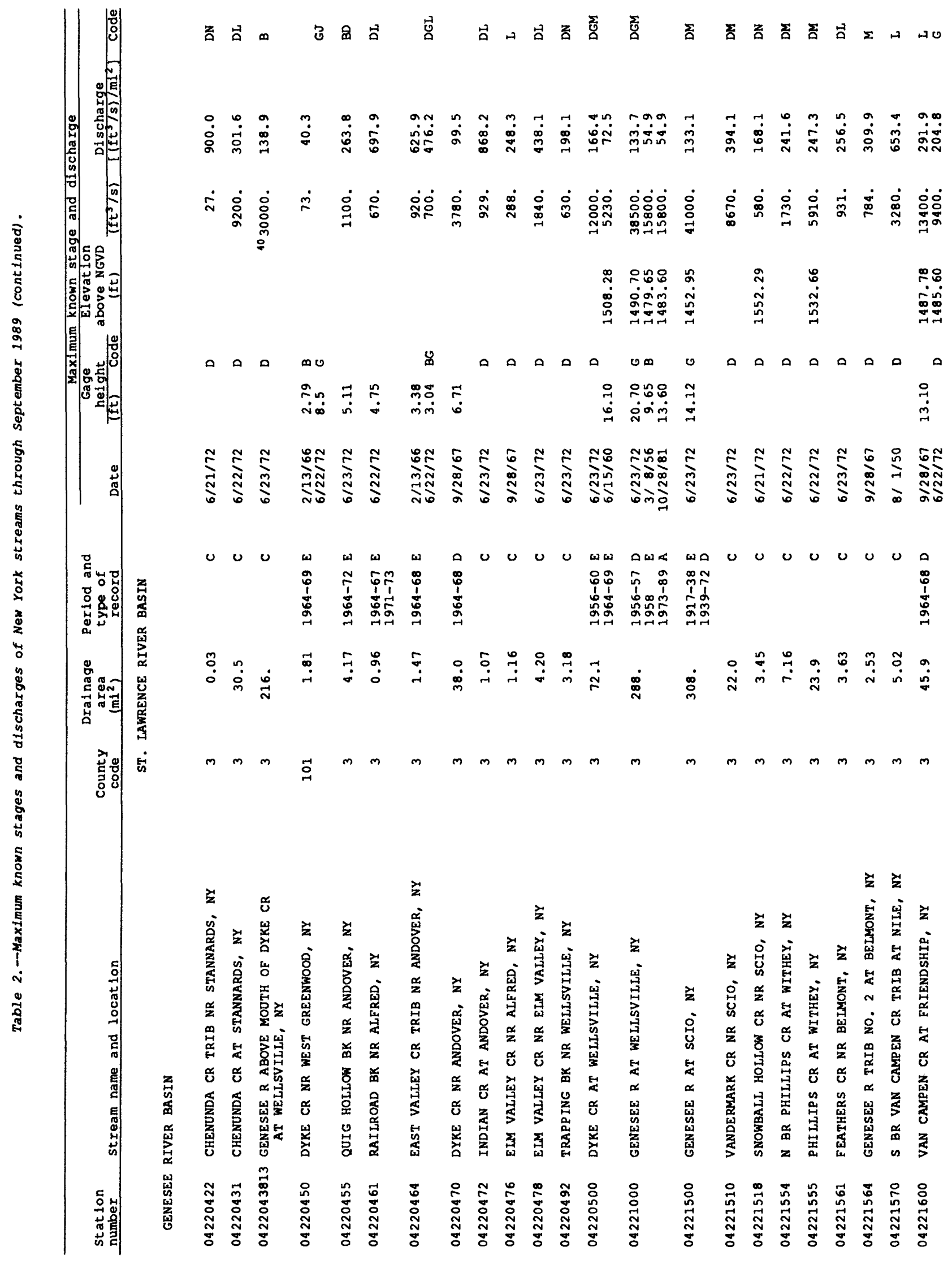




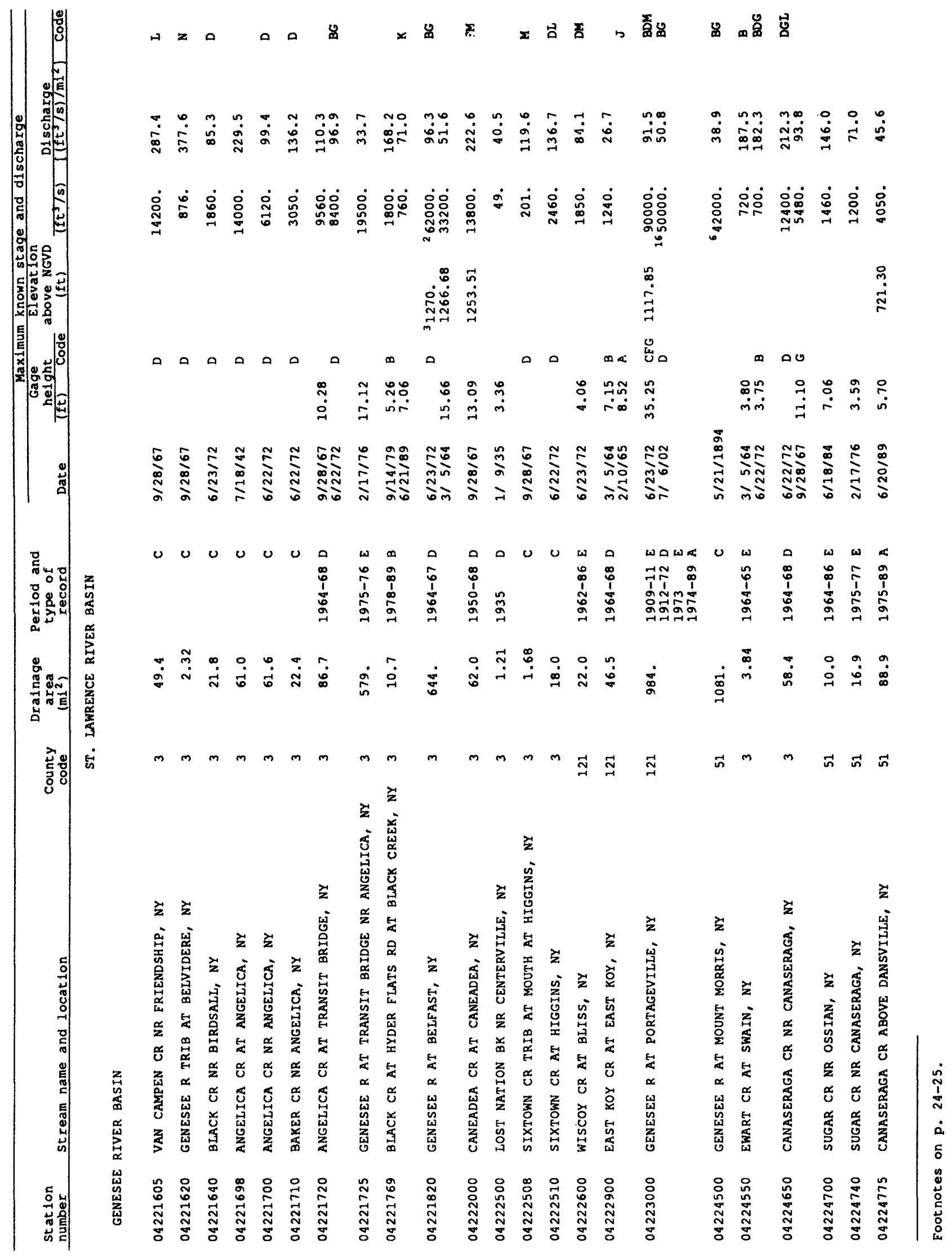




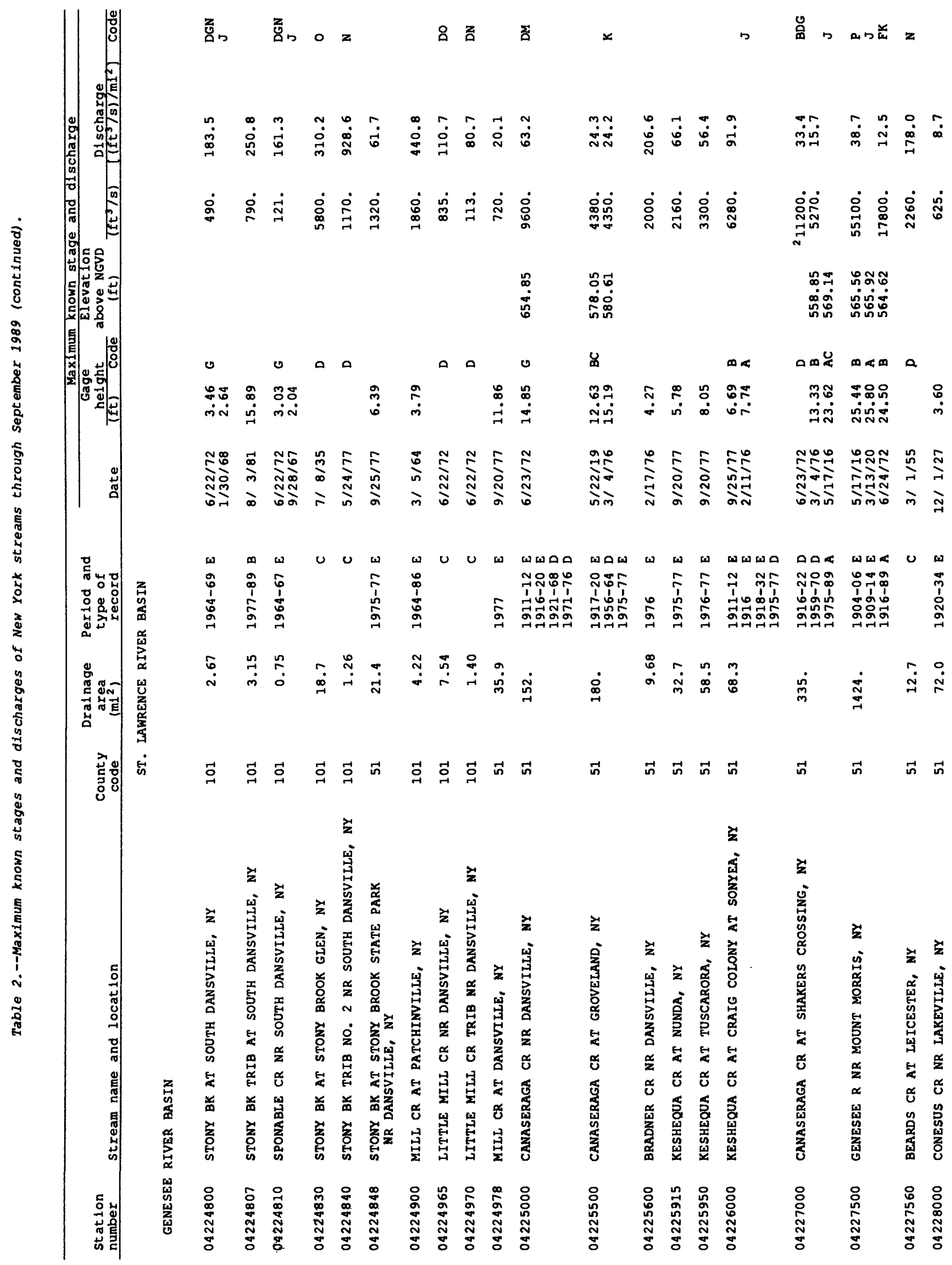




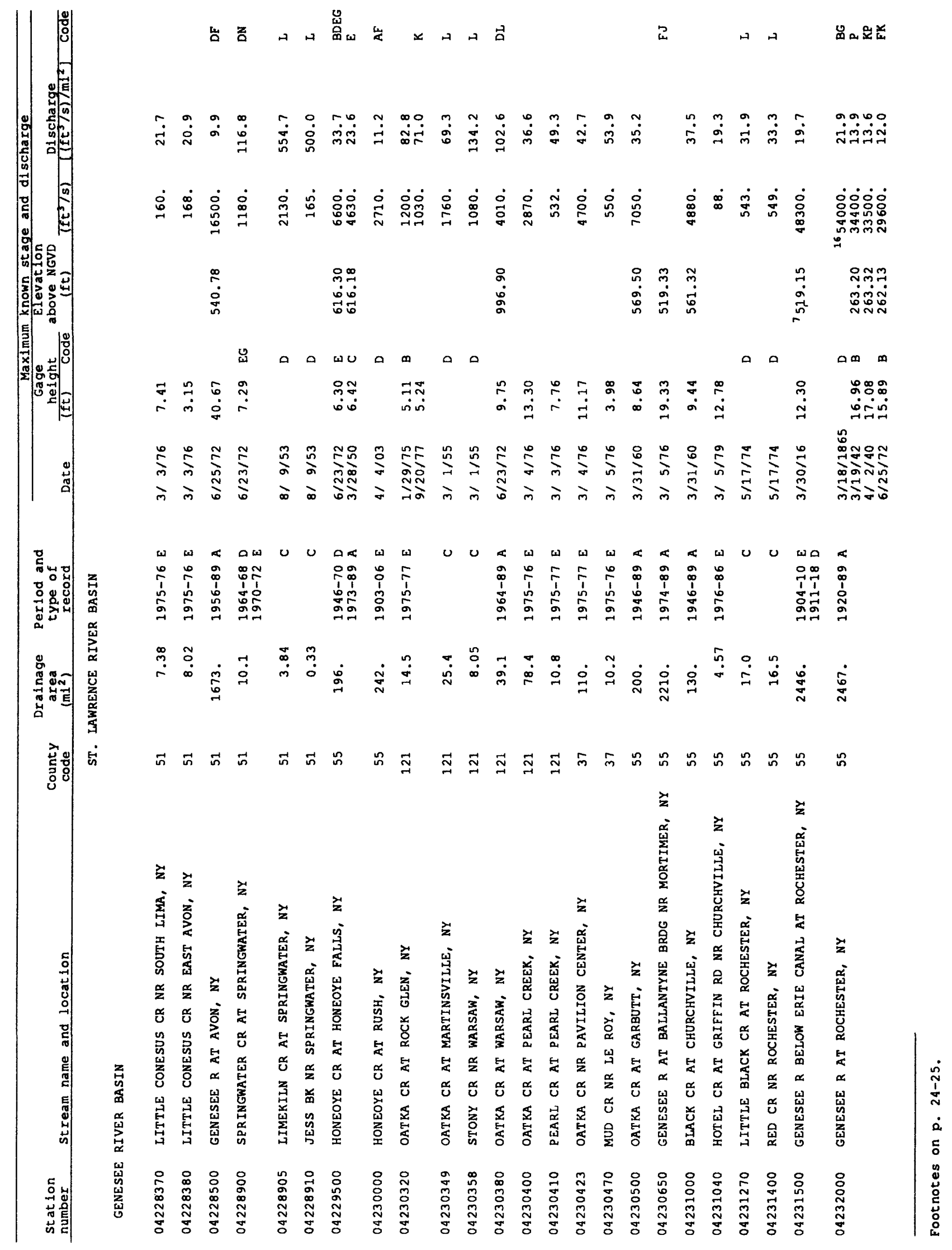




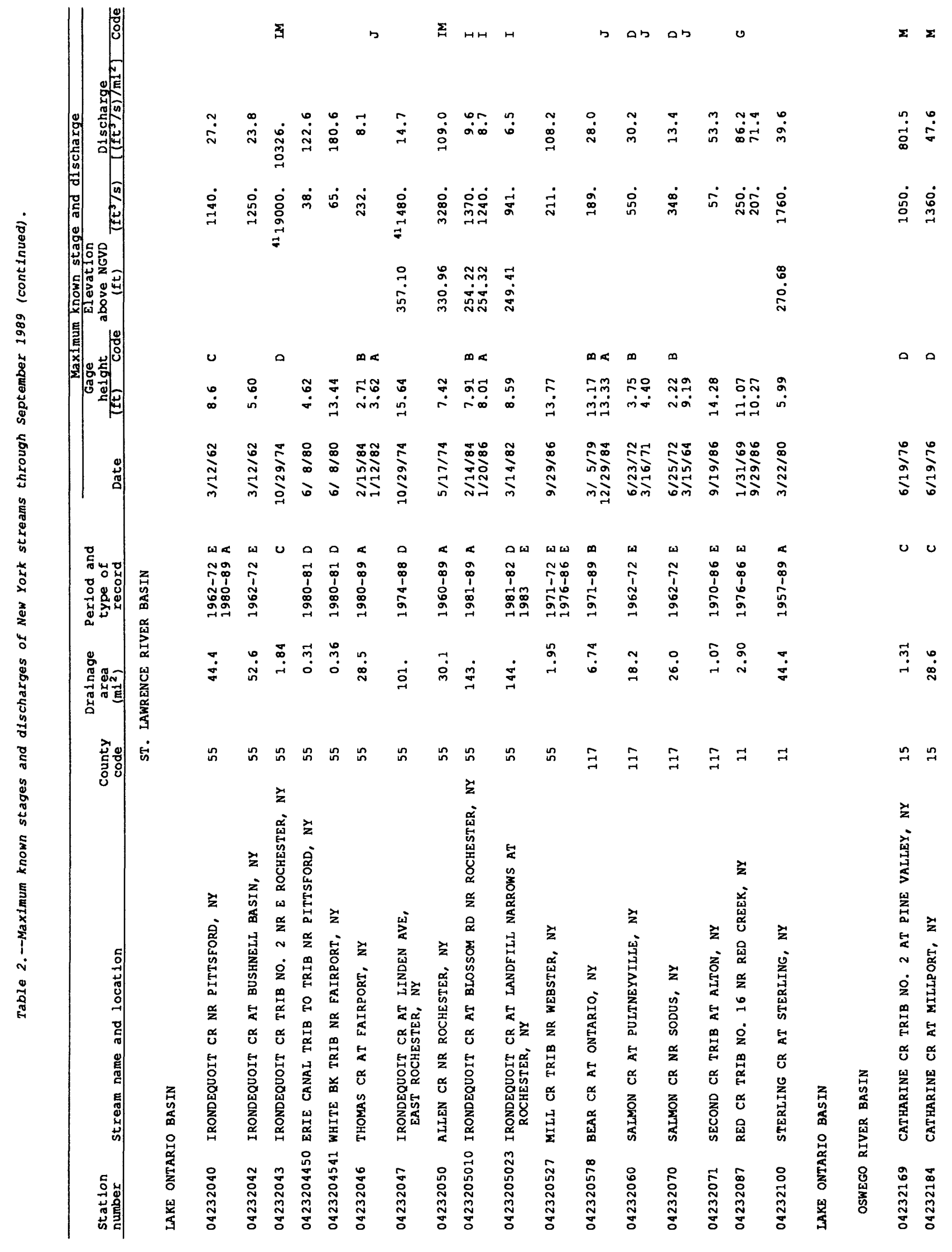




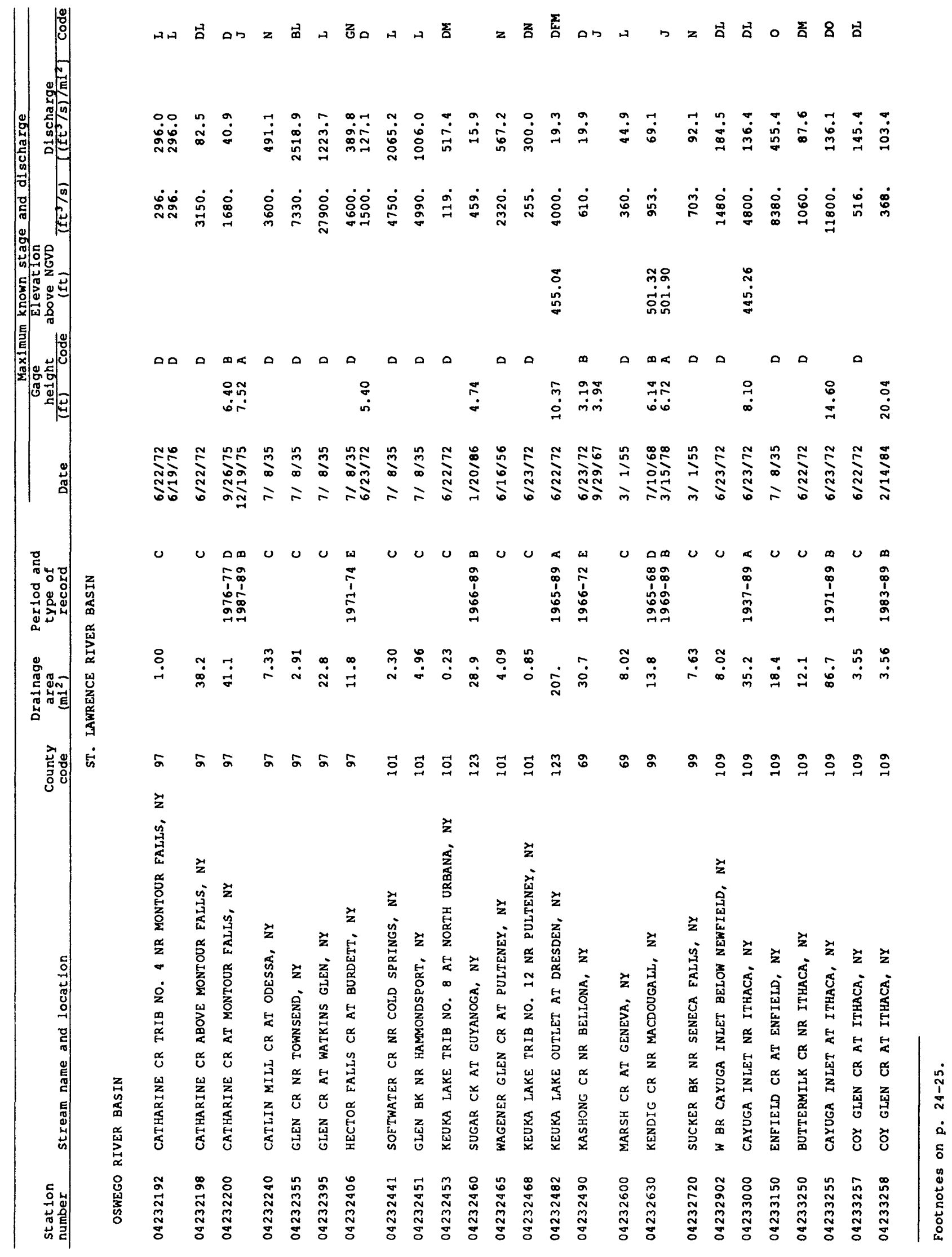




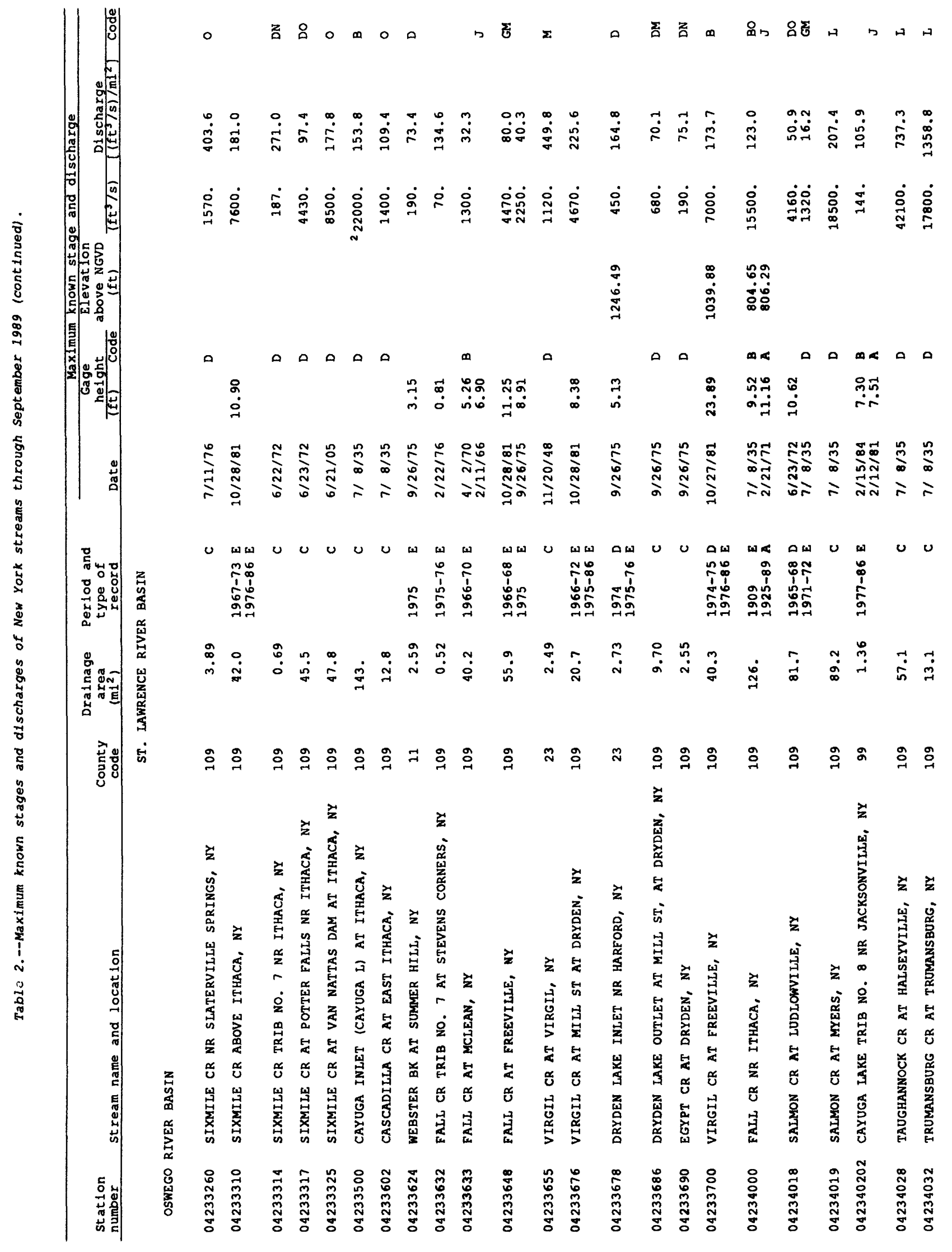




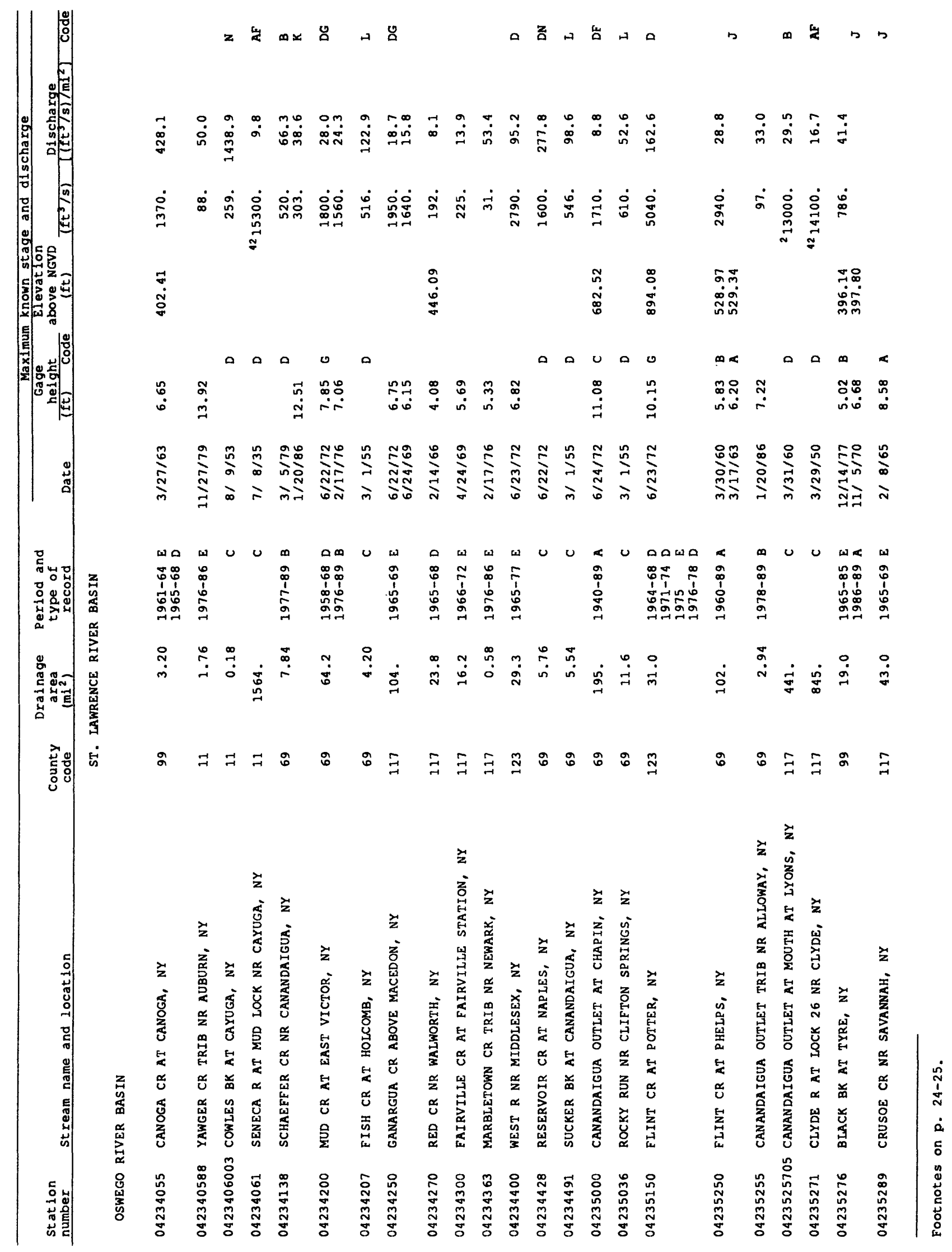




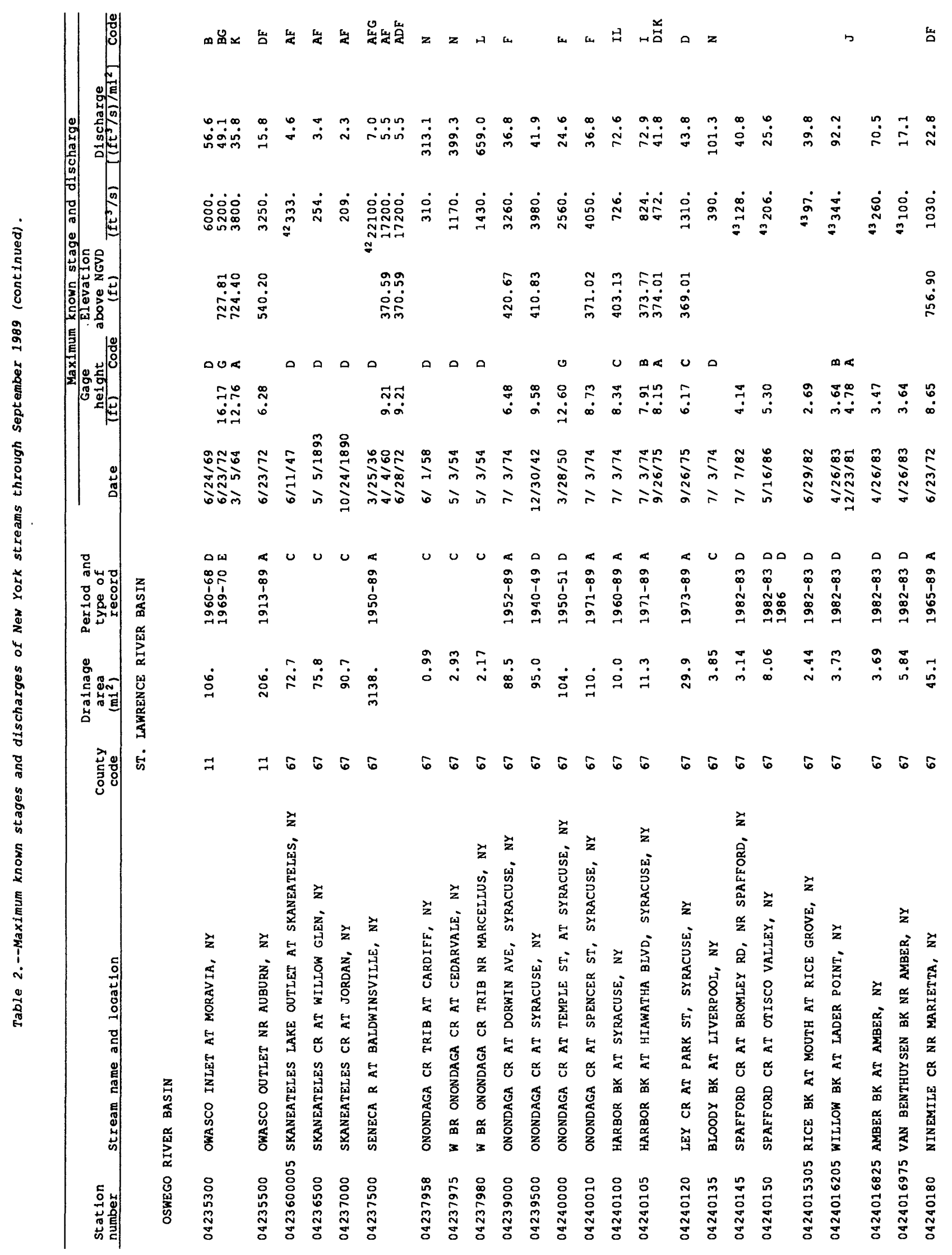




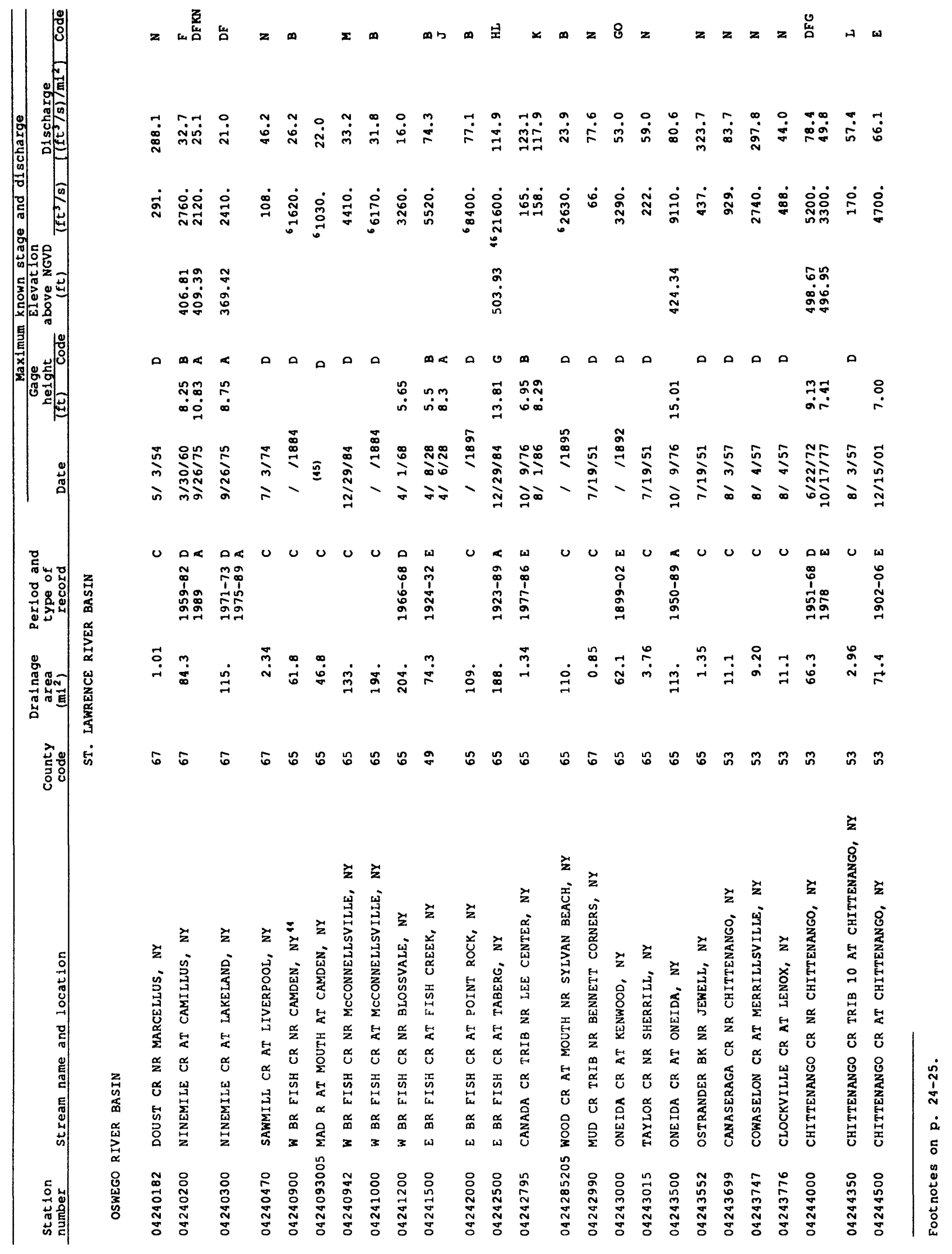




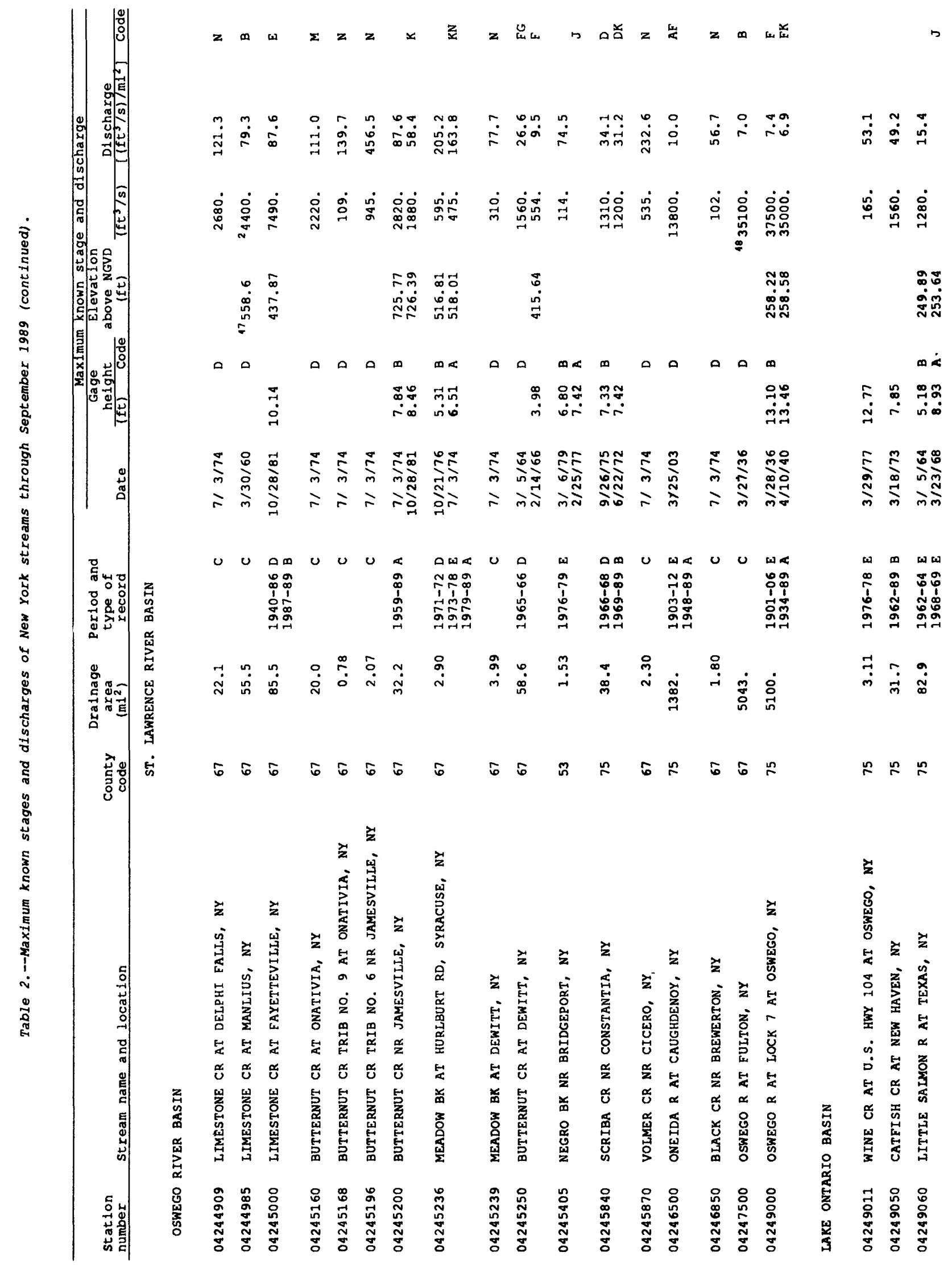




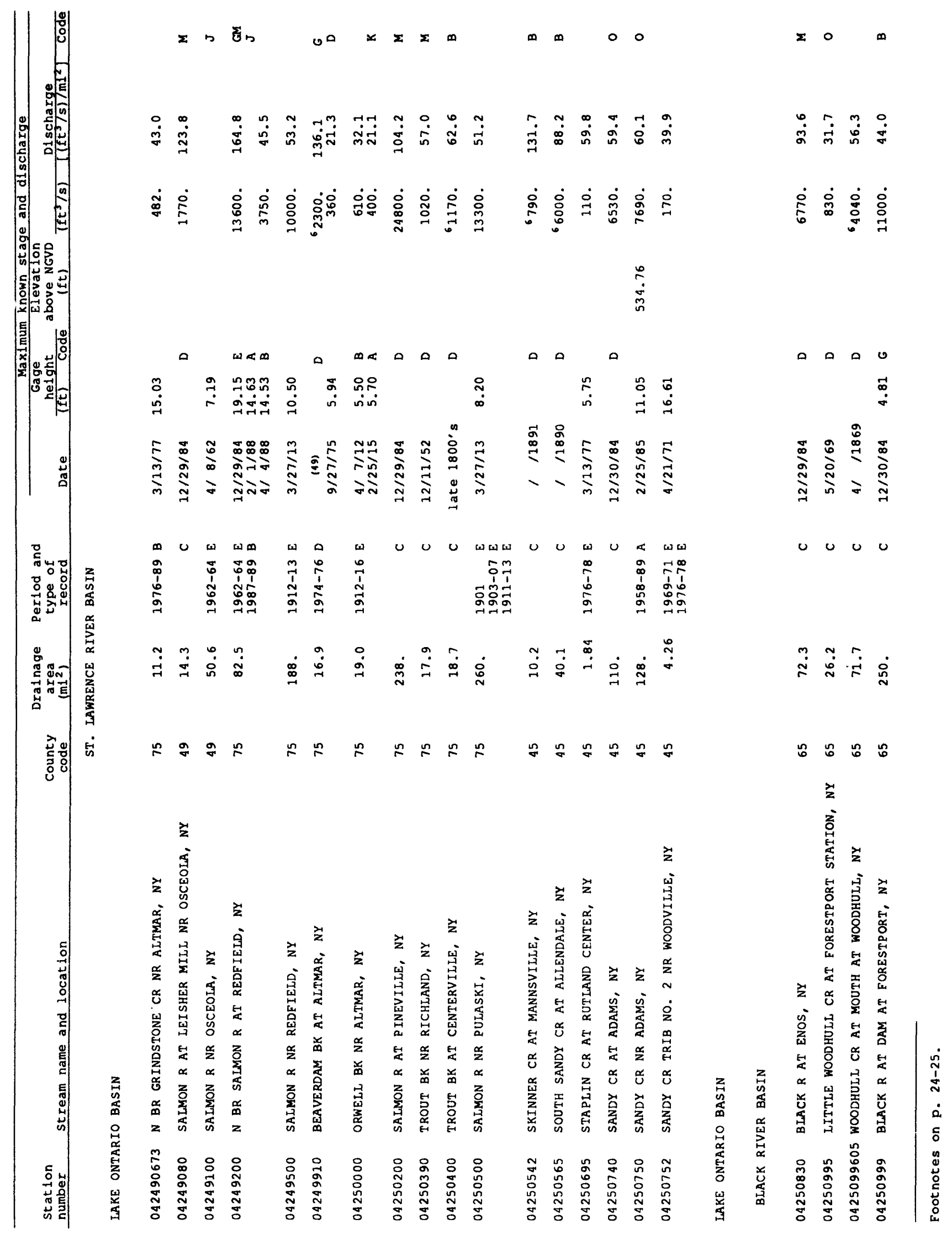




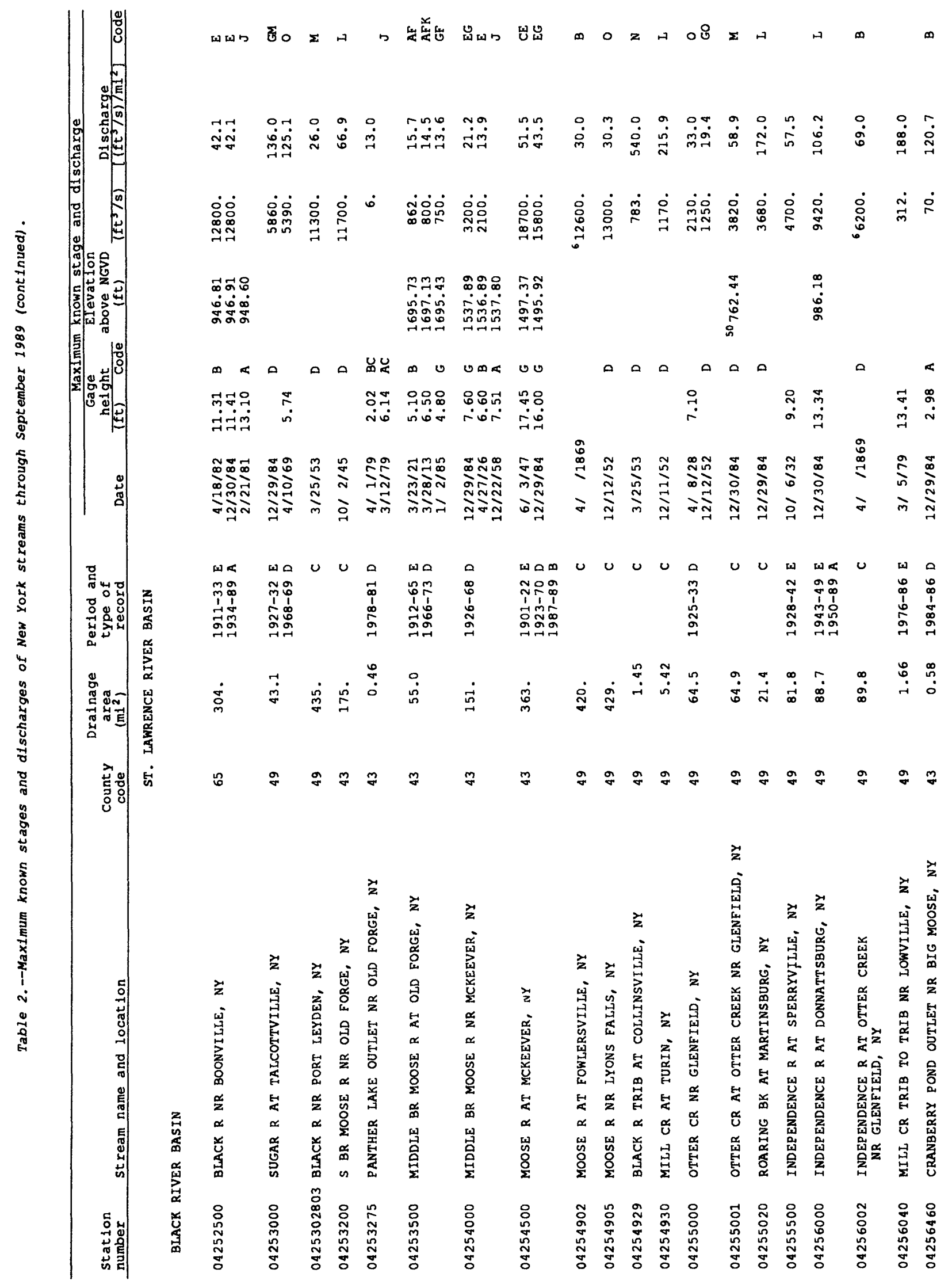




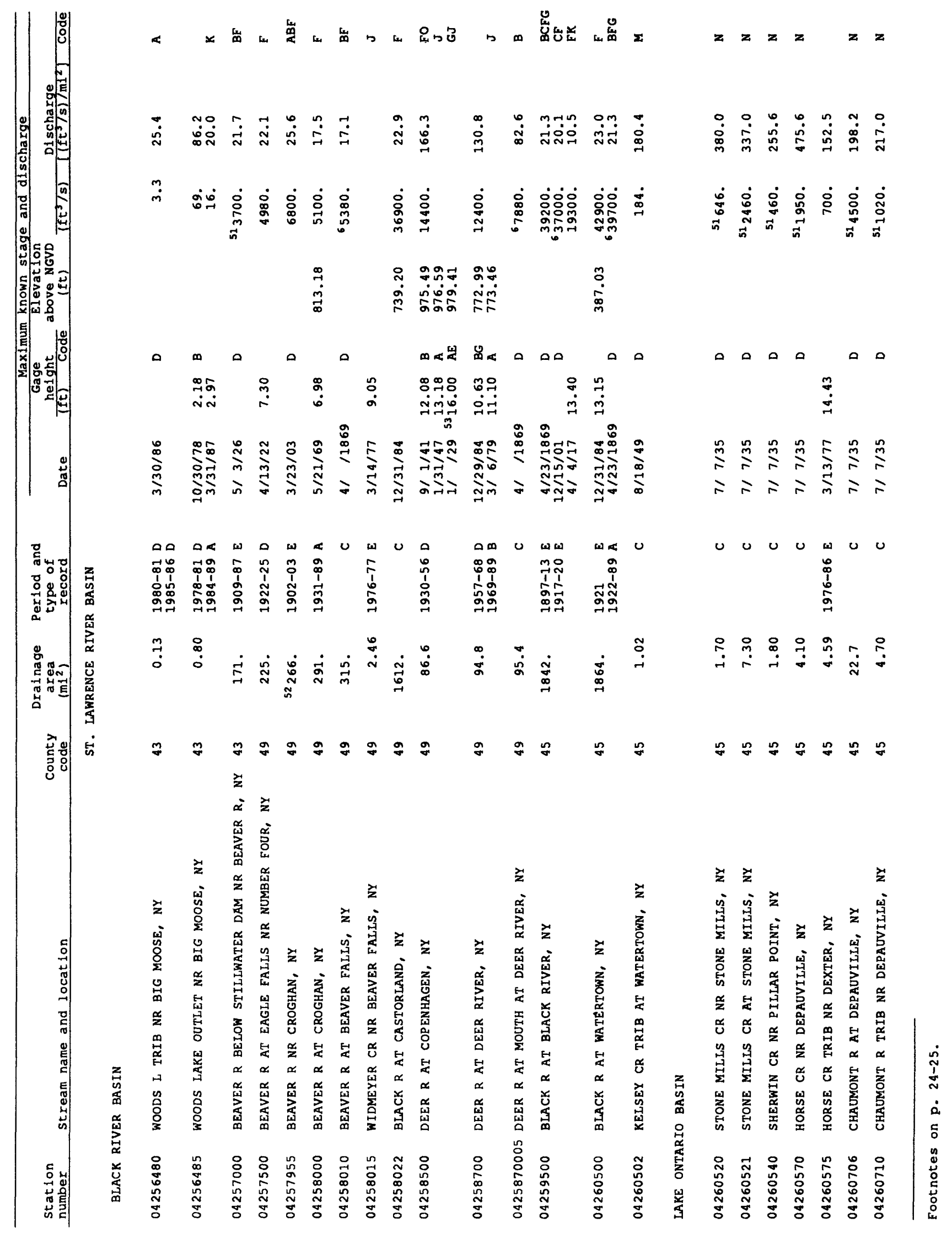




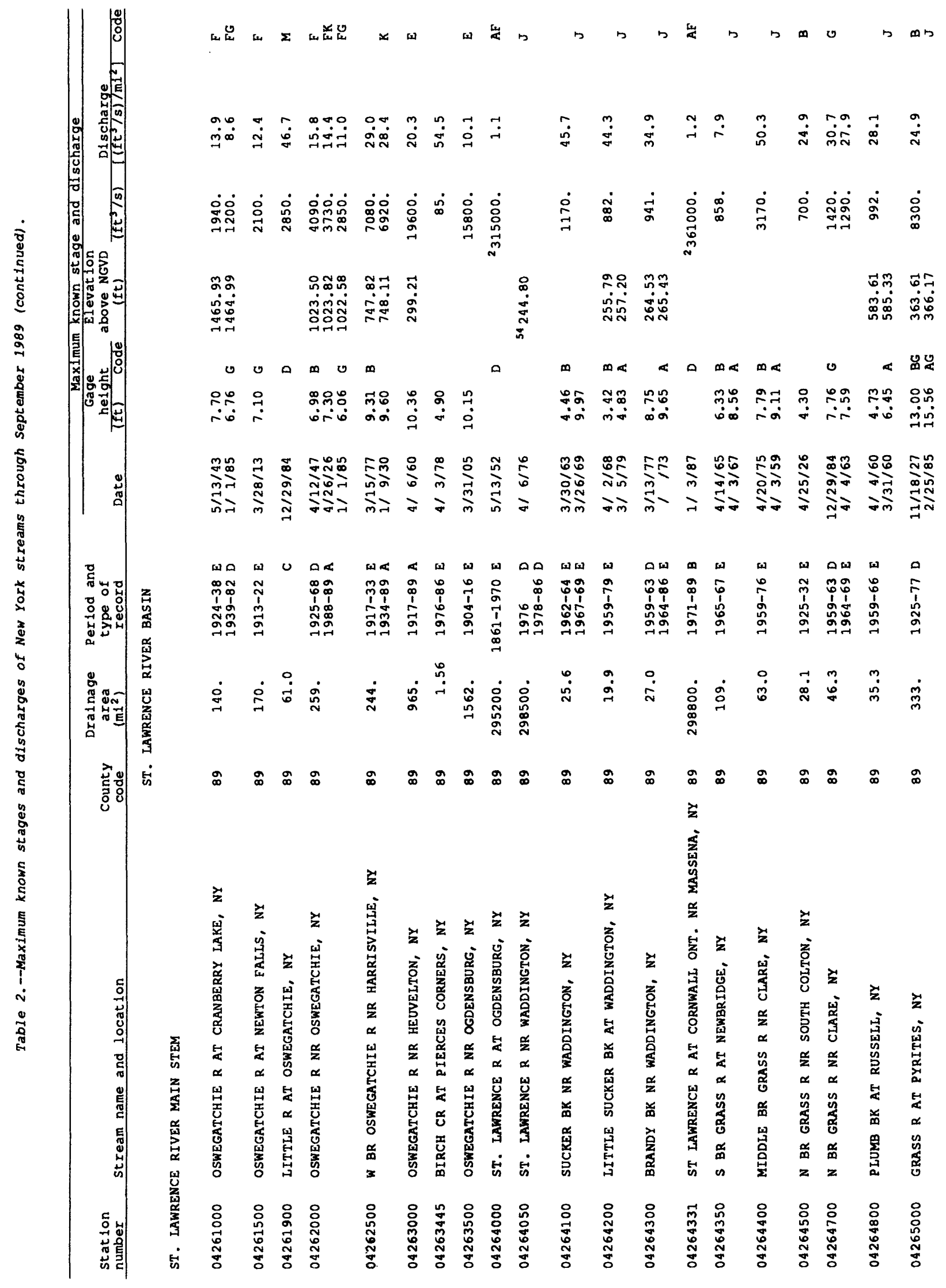




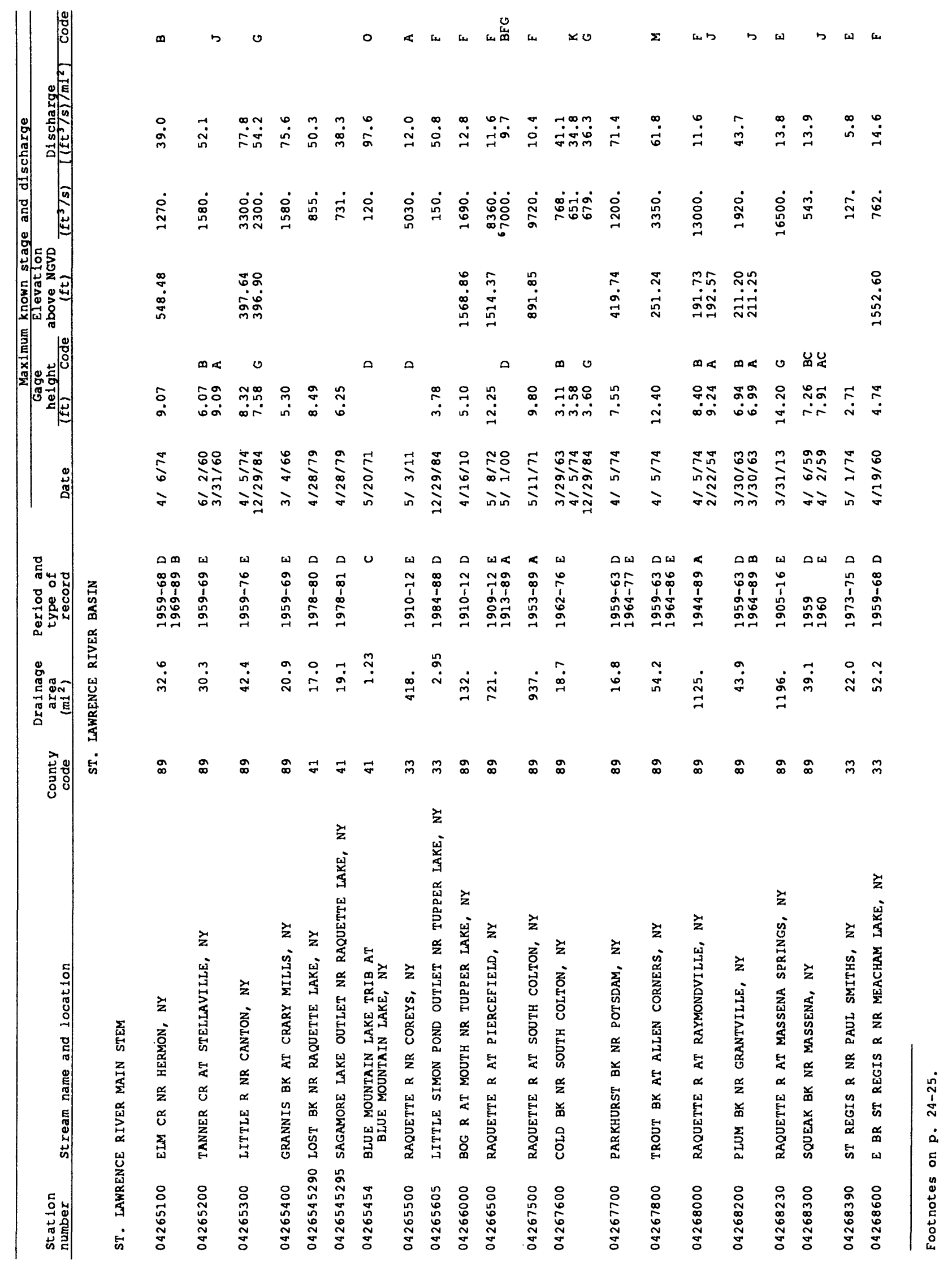




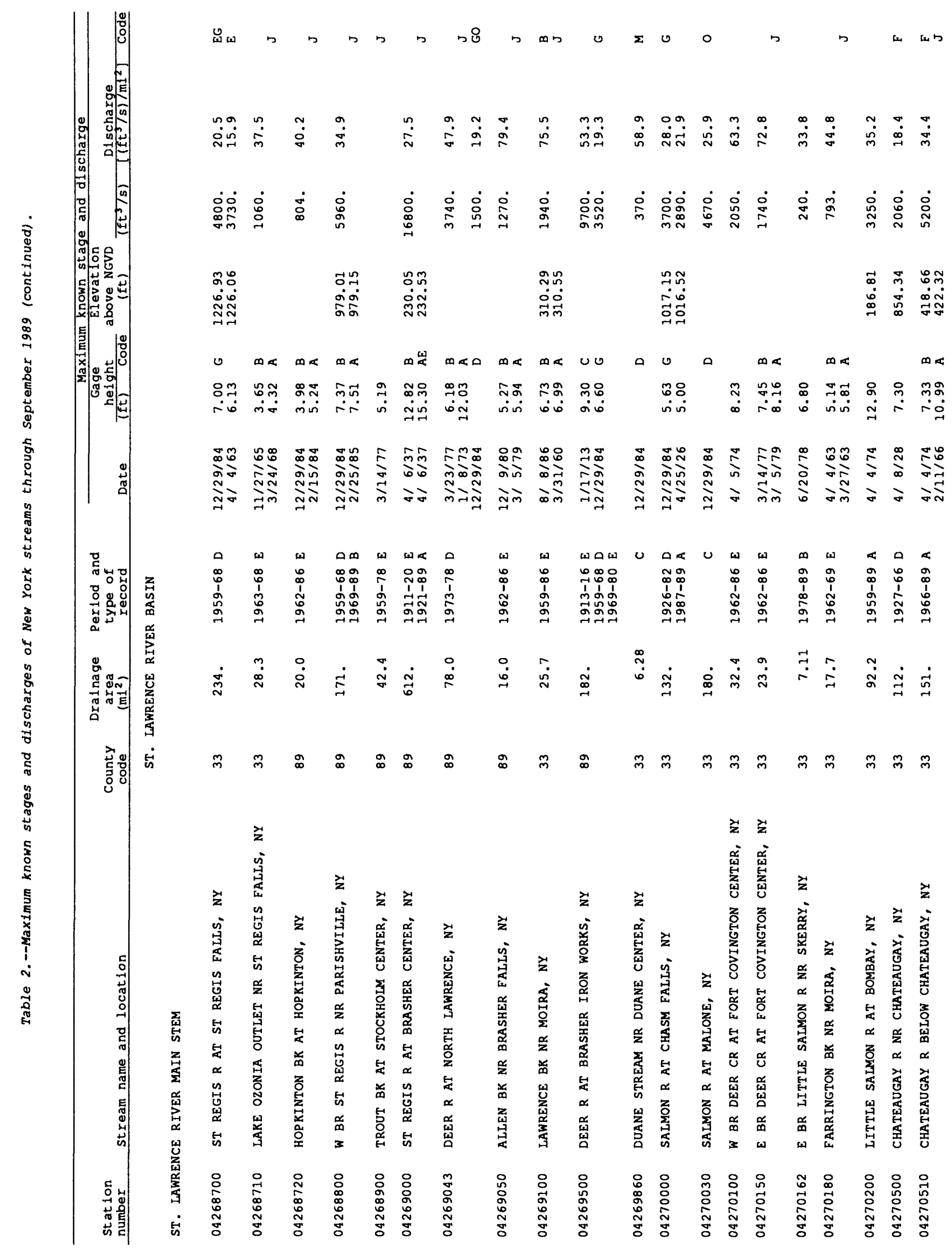




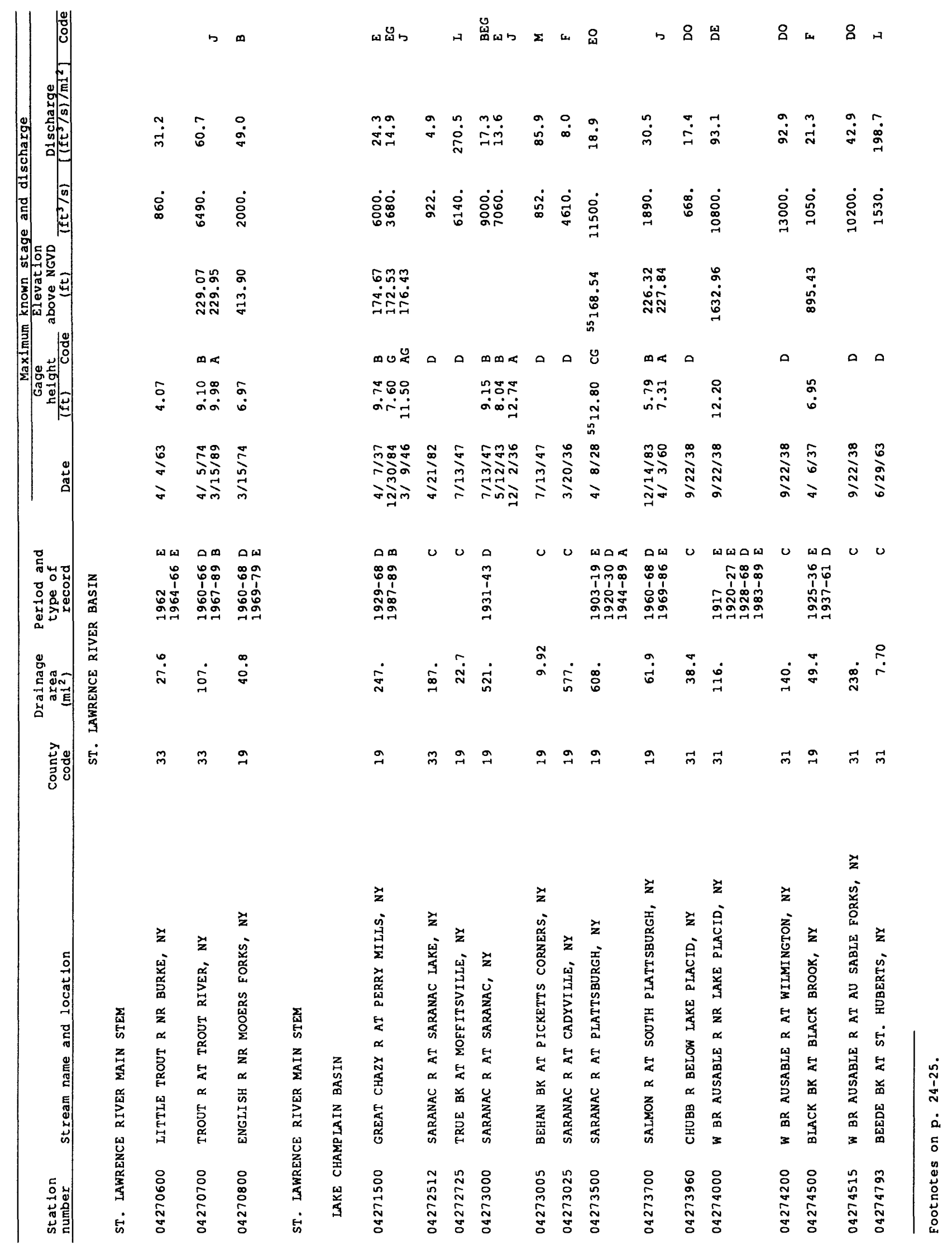




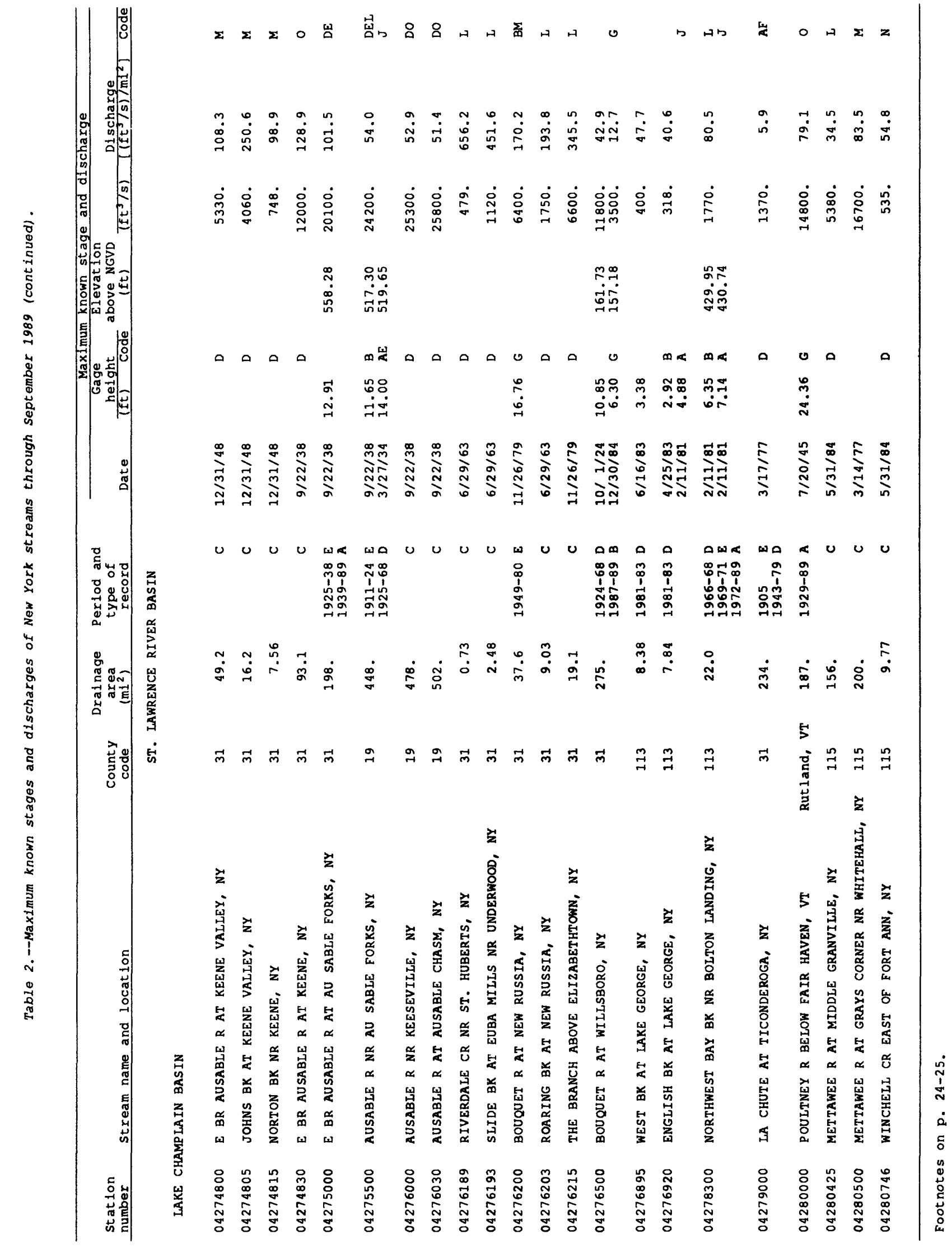




\section{Table 3}

\section{Alphabetical listing of stations shown in table 2, with location data.}

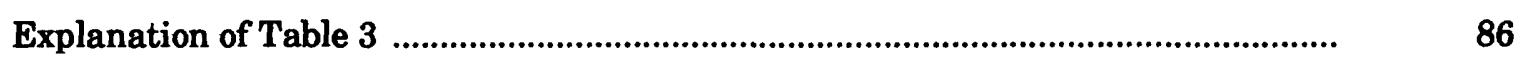

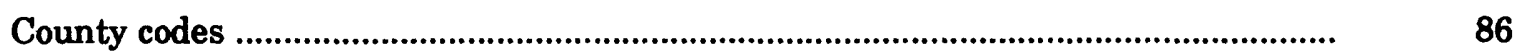

U.S. Geological Survey topographic quadrangle maps of New York,

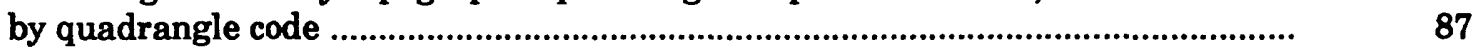

Alphabetical listing of stations shown in Table 2, with location data .......................... 


\section{Explanation of Table 3}

Table 3 lists in alphabetical order the station names given in table 2 and includes several categories of information on their locations. This index allows quick assessment of availability of maximum stage or discharge information for a stream of interest. Station names and numbers in table 3 are the same as in table 2.

Included for each site listed in table 3 are (1) latitude and longitude, in degrees, minutes, and seconds, (2) county code (see list below), (3) major river basin in which the site is located (fig. 1), (4) stream, lake, or ocean to which the site is tributary,
(5) the distance (in miles) between the site and the stream's mouth (if available), (6) the U.S. Geological Survey topographic quadrangle in which the site is located, and (7) hydrologic region in which the site is located. Topographic quadrangle names and codes are given on pages 87-91. The map codes are those used in the Geological Survey's quadrangle-identification system. All maps are 7.5-minute topographic quadrangles except those whose last code symbol is A or B, which indicates that only a 7.5- by 15-minute topographic map was available at the time of report preparation.

Codes Used in Table 3.

County Codes

\begin{tabular}{rlrlrl}
\hline Code & County & Code & County & Code & County \\
\hline 1 & Albany & 43 & Herkimer & 85 & Richmond \\
3 & Allegany & 45 & Jefferson & 87 & Rockland \\
5 & Bronx & 47 & Kings & 89 & St. Lawrence \\
7 & Broome & 49 & Lewis & 91 & Saratoga \\
9 & Cattaraugus & 51 & Livingston & 93 & Schenectady \\
11 & Cayuga & 53 & Madison & 95 & Schoharie \\
13 & Chautauqua & 55 & Monroe & 97 & Schuyler \\
15 & Chemung & 57 & Montgomery & 99 & Seneca \\
17 & Chenango & 59 & Nassau & 101 & Steuben \\
19 & Clinton & 61 & New York & 103 & Suffolk \\
21 & Columbia & 63 & Niagara & 105 & Sullivan \\
23 & Cortland & 65 & Oneida & 107 & Tioga \\
25 & Delaware & 67 & Onondaga & 109 & Tompkins \\
27 & Dutchess & 69 & Ontario & 111 & Ulster \\
29 & Erie & 71 & Orange & 113 & Warren \\
31 & Essex & 73 & Orleans & 115 & Washington \\
33 & Franklin & 75 & Oswego & 117 & Wayne \\
35 & Fulton & 77 & Otsego & 119 & Westchester \\
37 & Genesee & 79 & Putnam & 121 & Wyoming \\
39 & Greene & 81 & Queens & 123 & Yates \\
41 & Hamilton & 83 & Rensselaer & & \\
\hline & & & & & \\
\hline
\end{tabular}




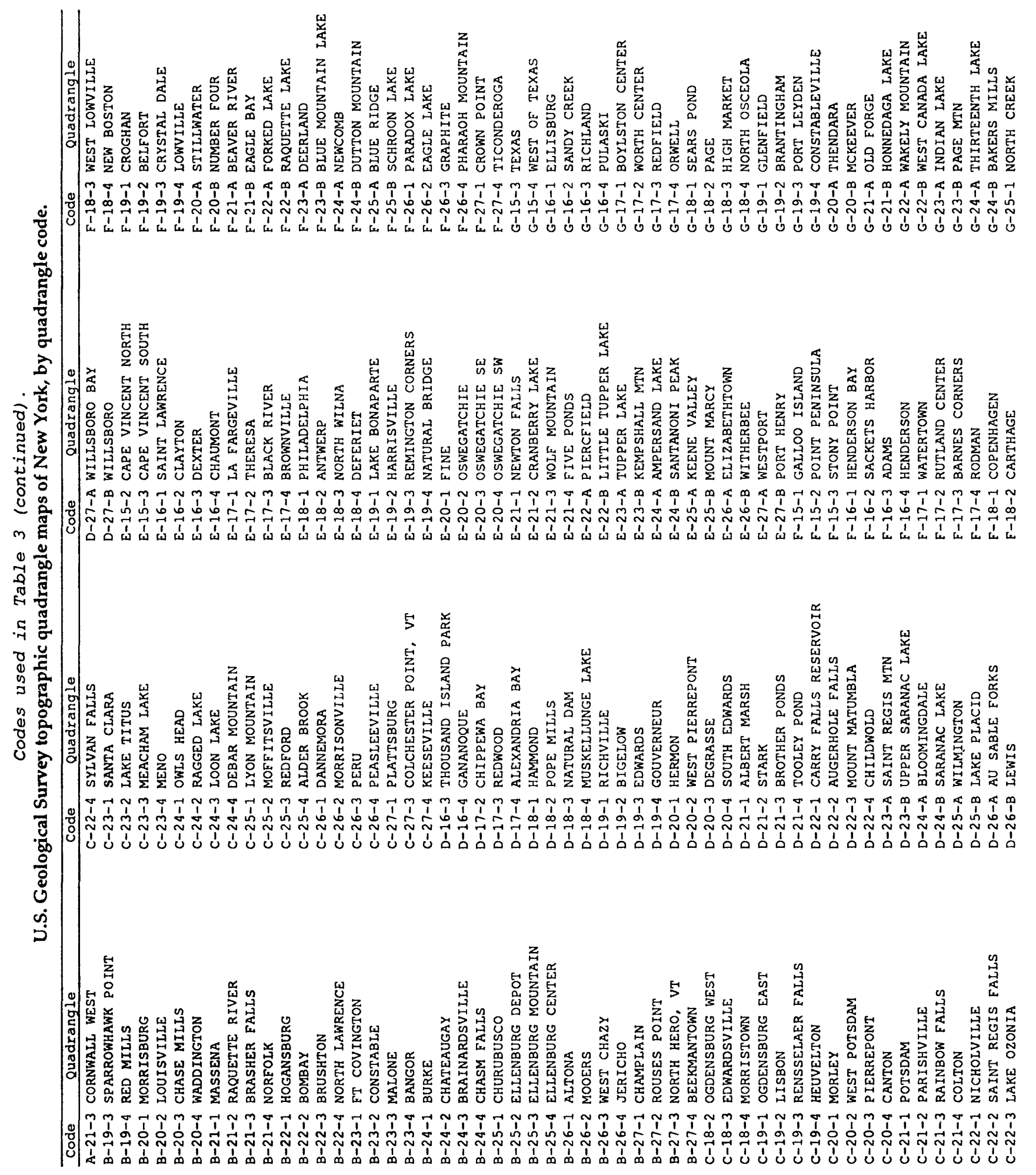




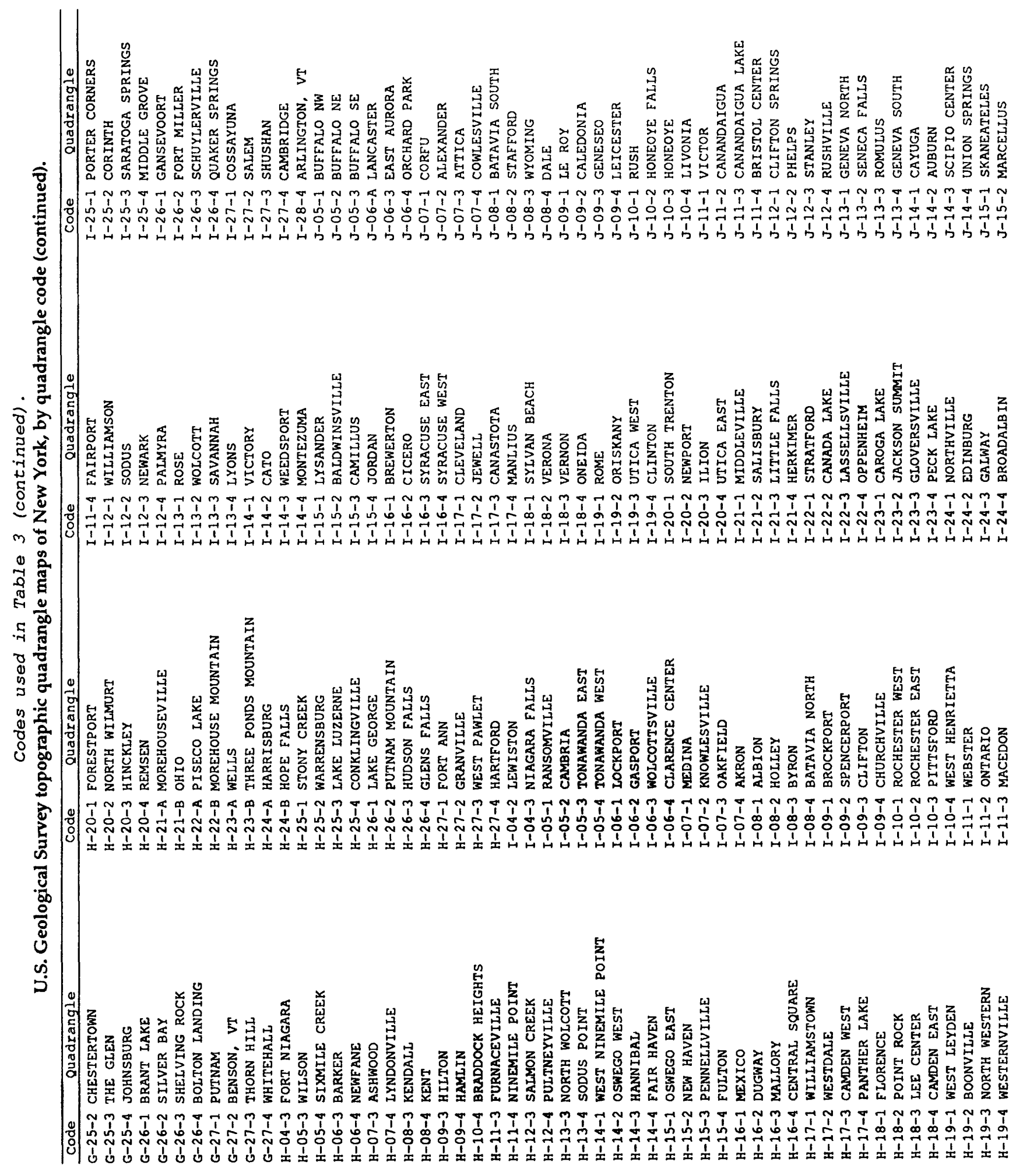




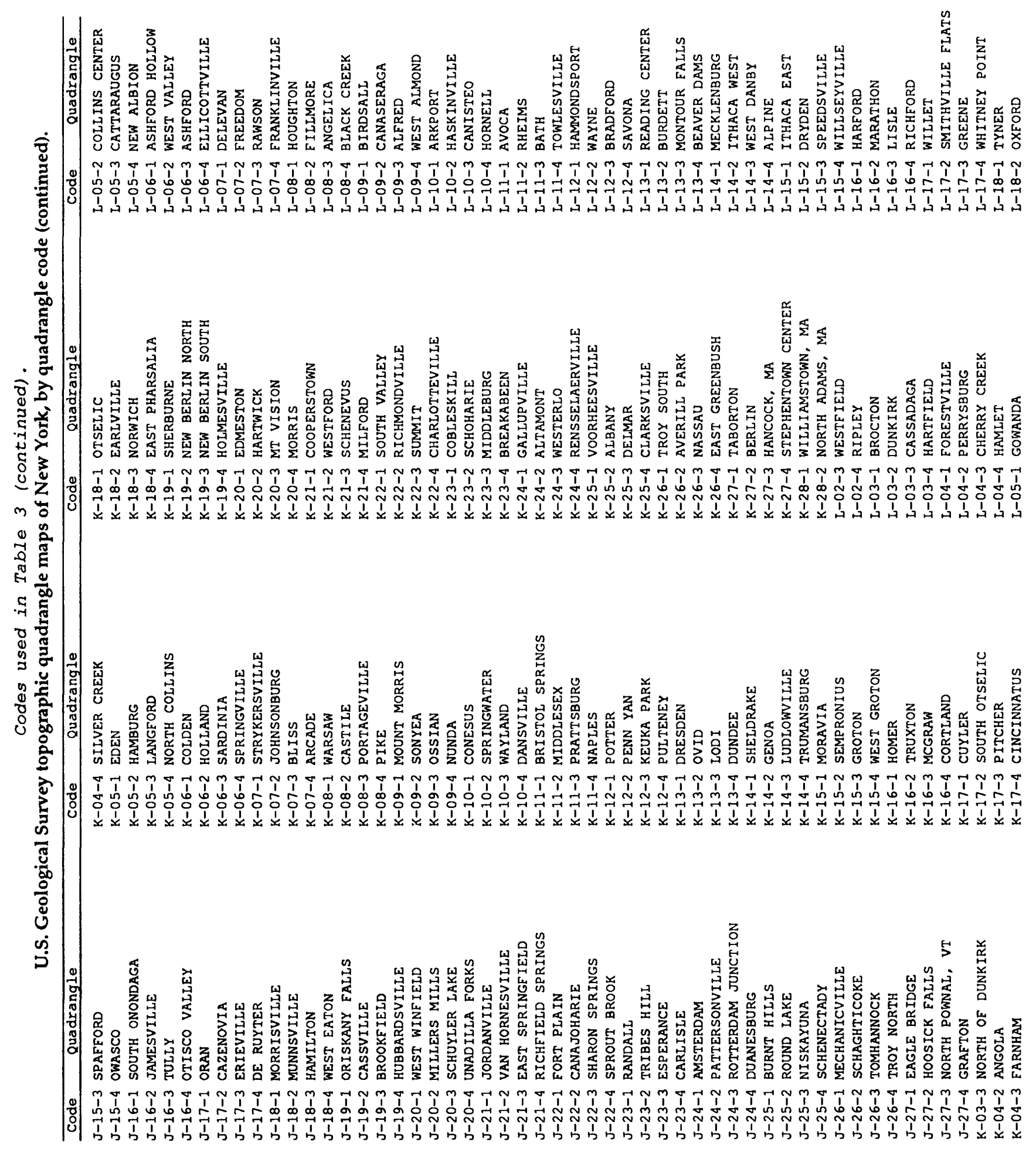




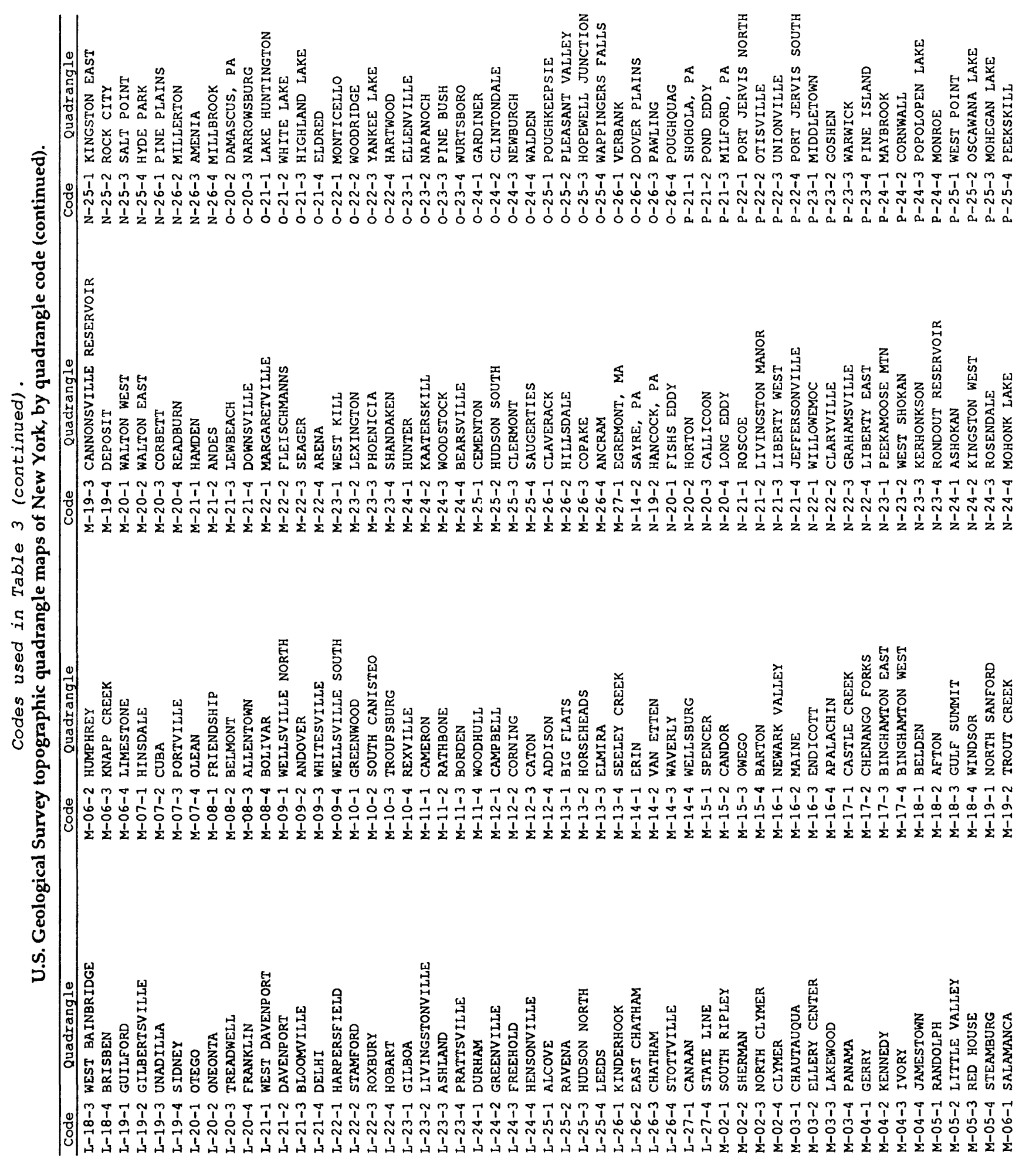




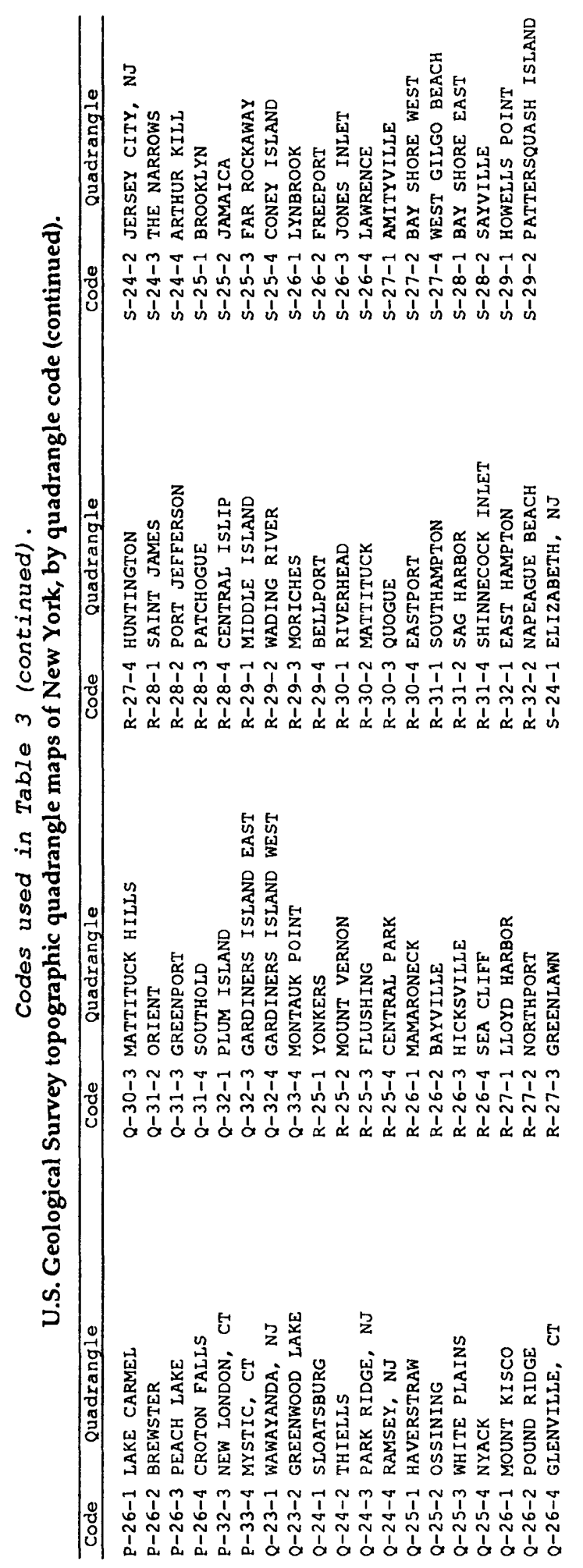




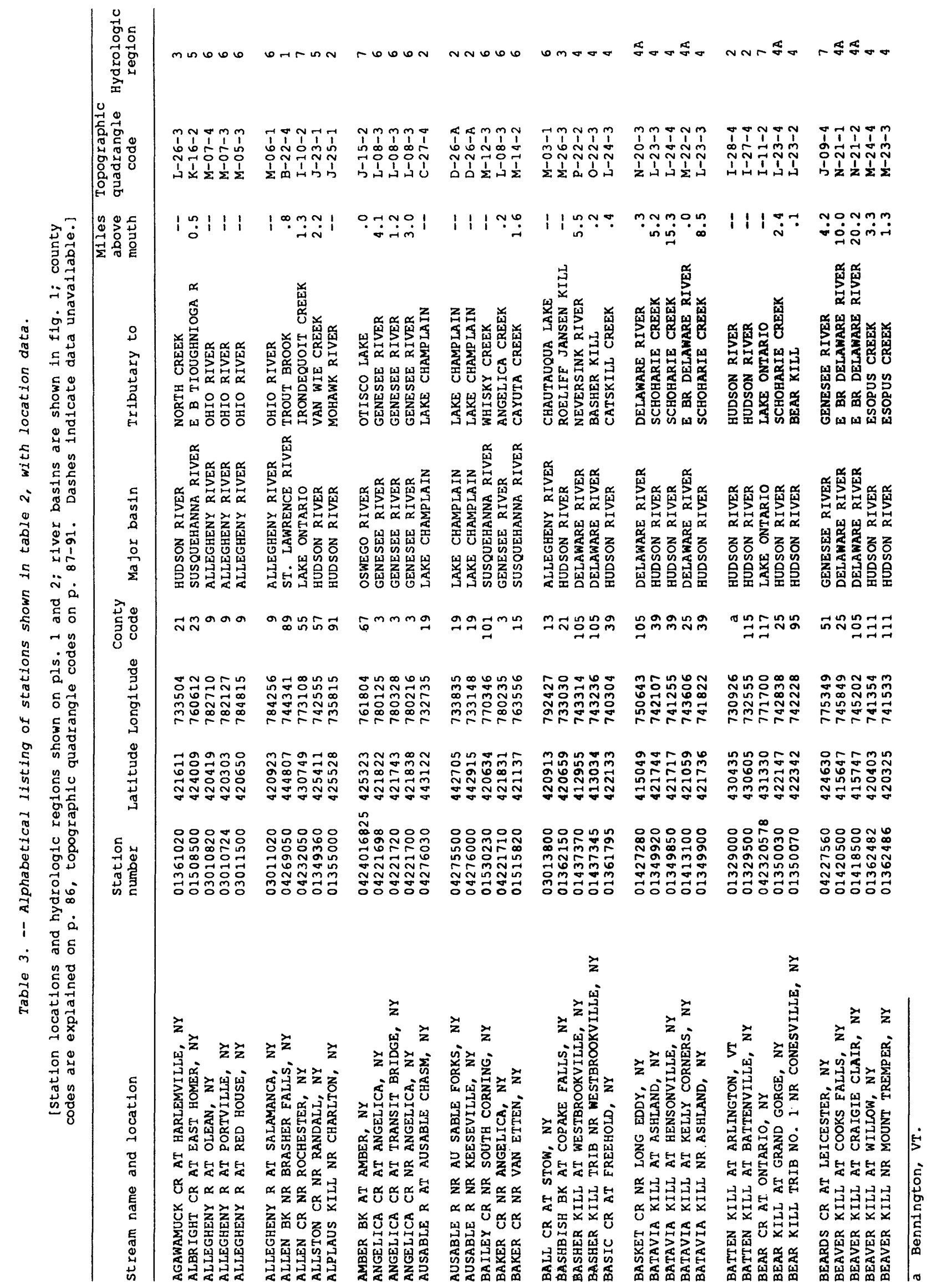




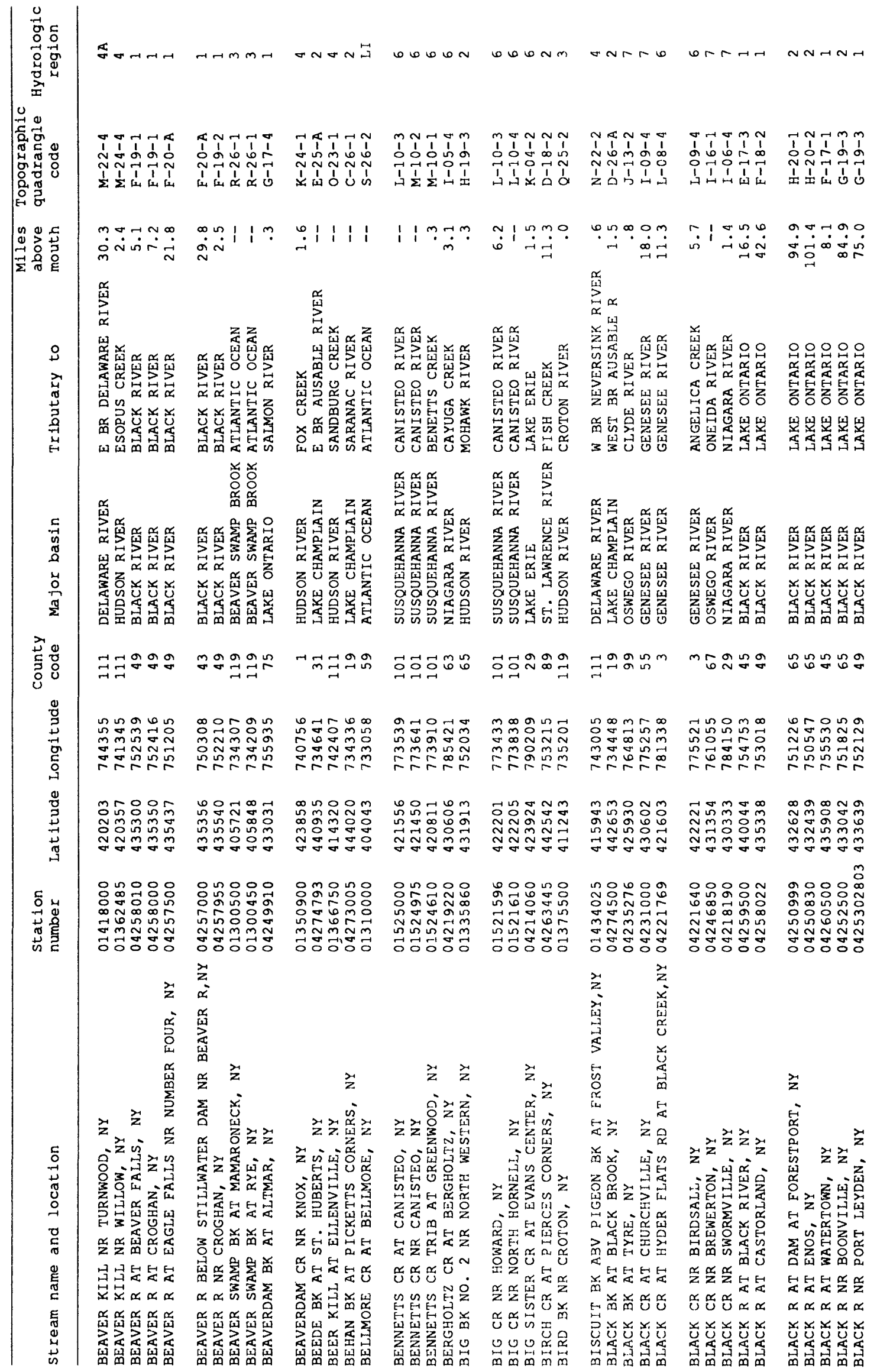




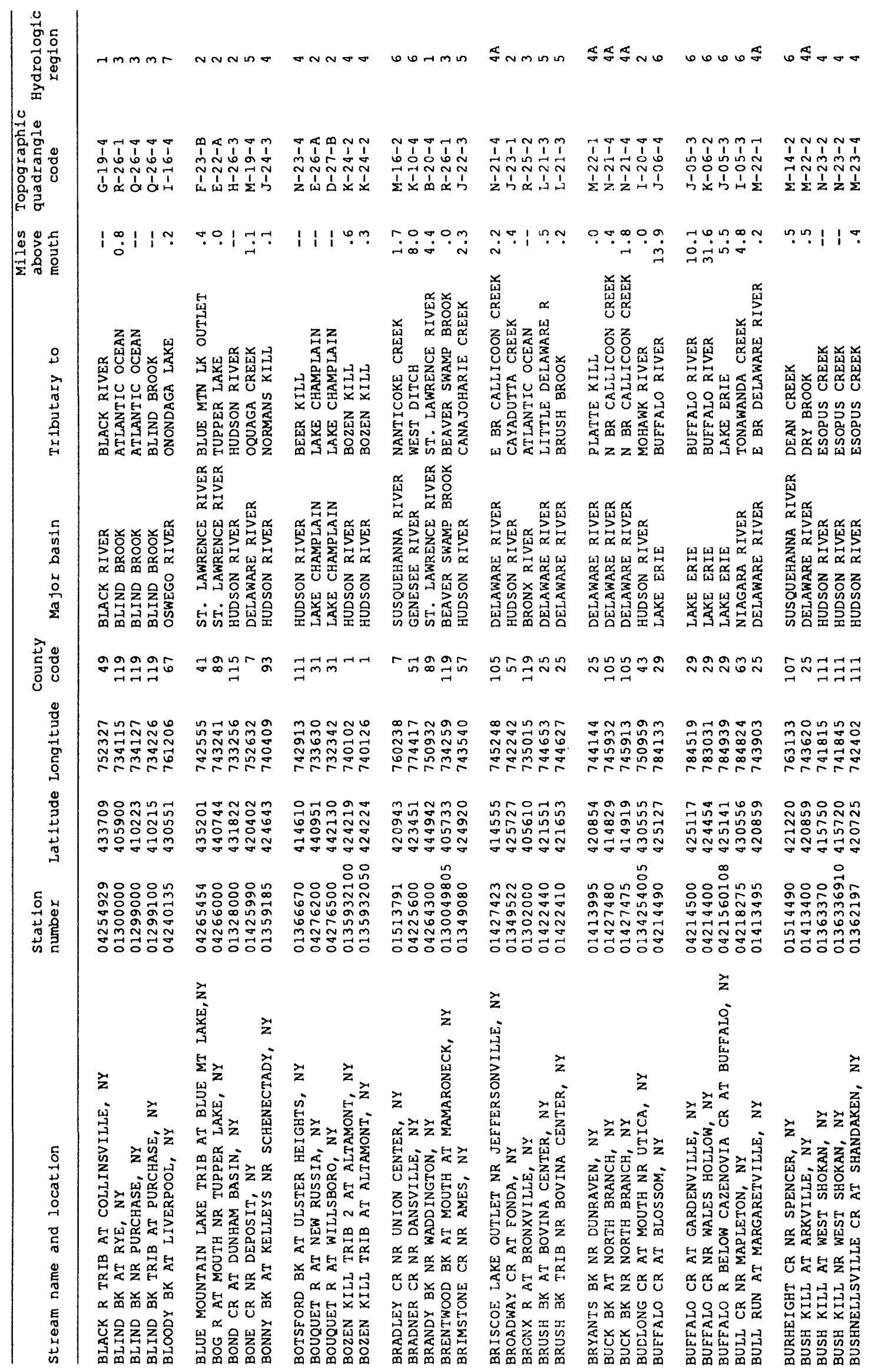




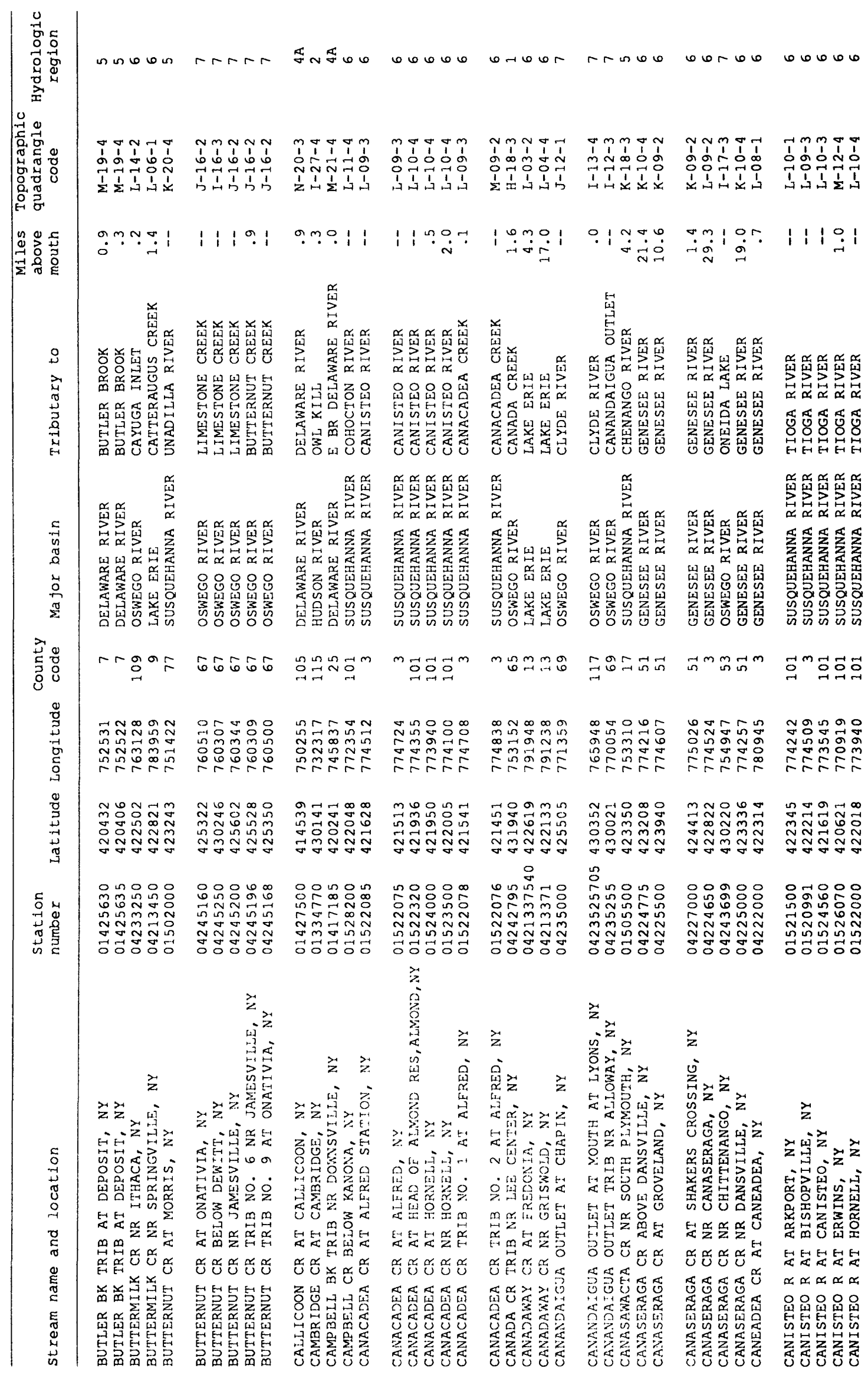




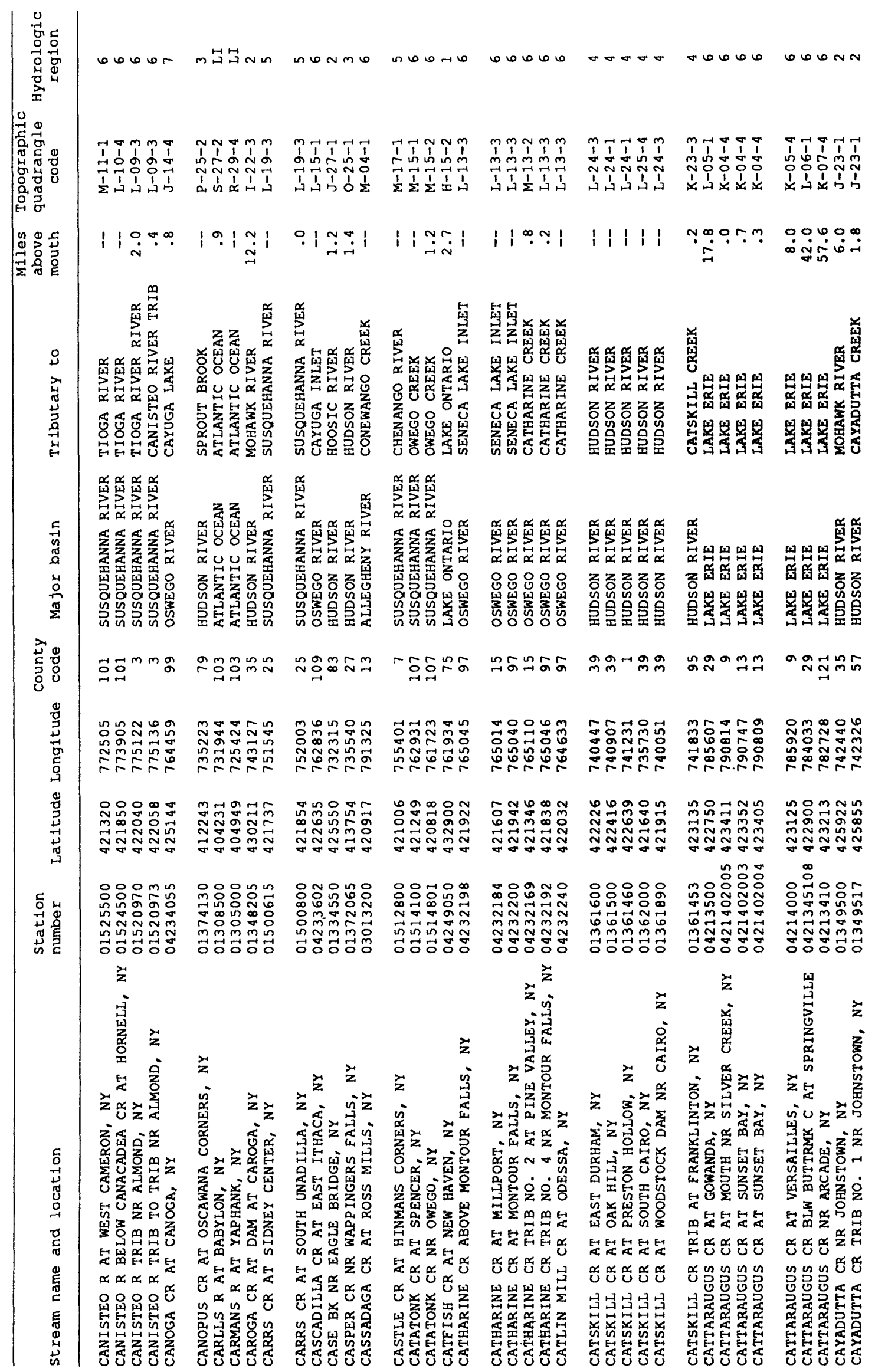




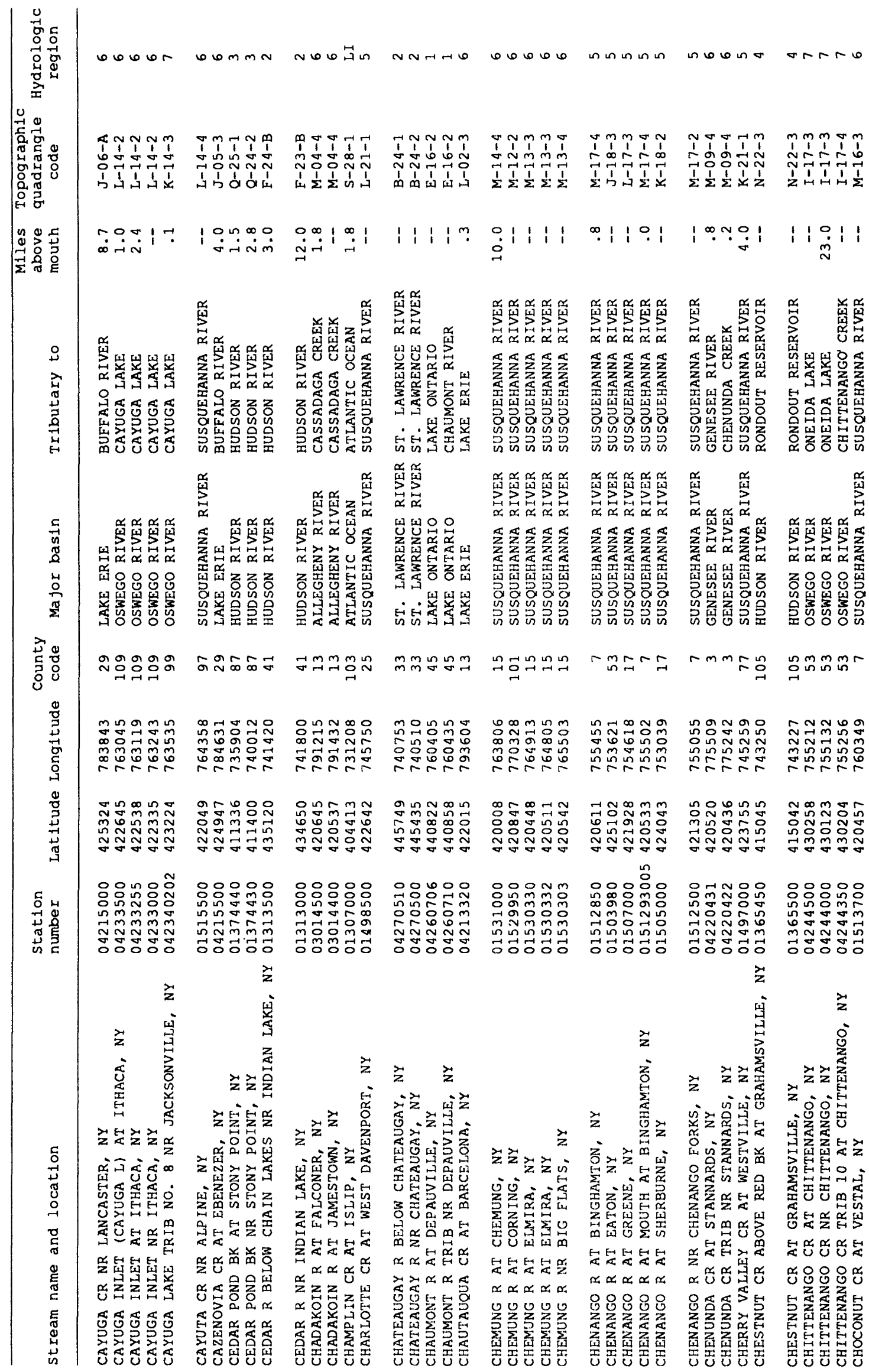




\begin{tabular}{|c|c|c|c|c|c|c|c|c|}
\hline 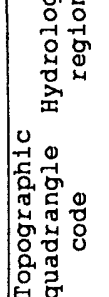 & 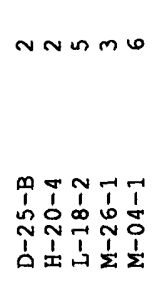 & 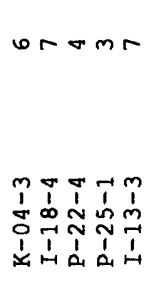 & 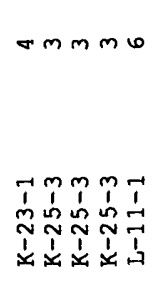 & 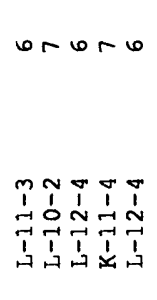 & 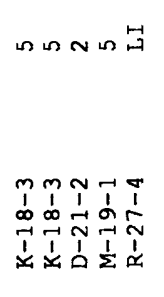 & 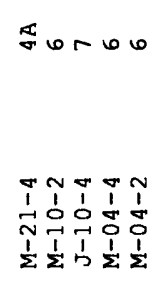 & 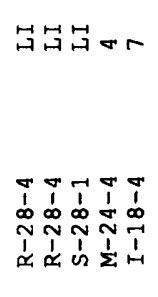 & 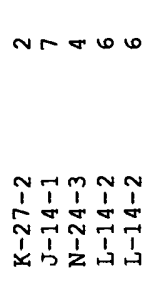 \\
\hline 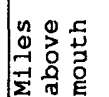 & 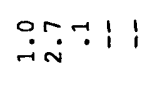 & 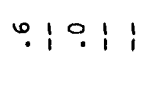 & $\begin{array}{lllll}0 & 1 & 1 & 1 & 1\end{array}$ & $\begin{array}{lllll}1 & 1 & 1 & 1 & 1\end{array}$ & 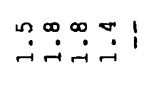 & \begin{tabular}{l|l|l|l}
$\infty$ & $\infty$ & 0 & 1
\end{tabular} & 11 & m? \\
\hline 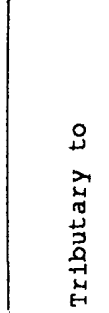 & 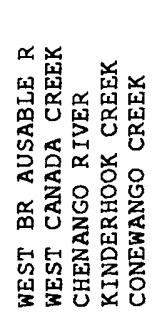 & 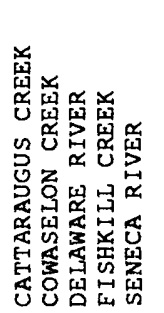 & 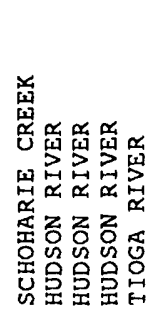 & 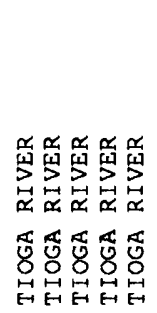 & 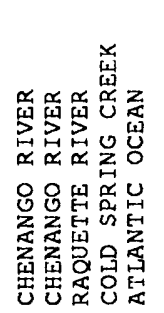 & 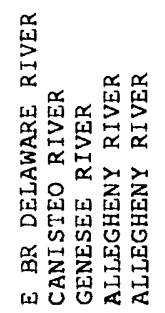 & 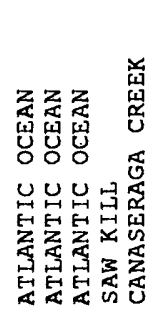 & 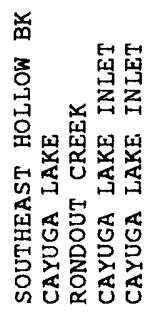 \\
\hline 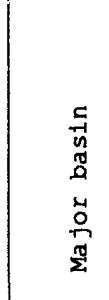 & 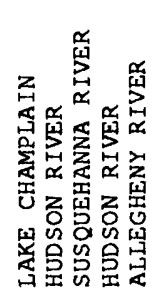 & 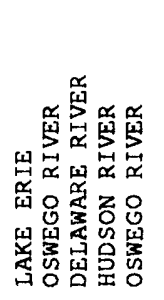 & 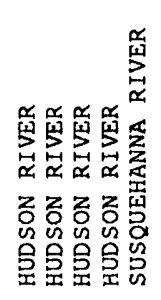 & 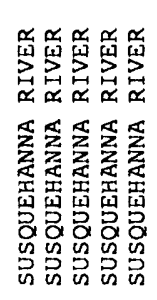 & 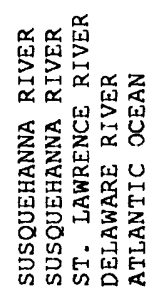 & 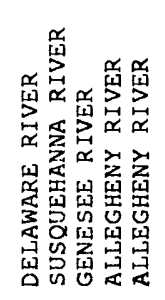 & 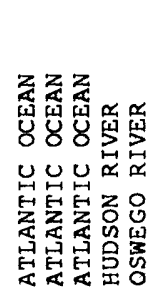 & 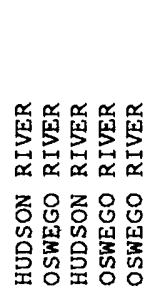 \\
\hline 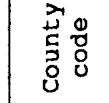 & 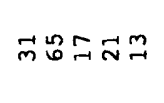 & ลิㅗㅛ & 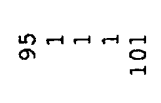 & 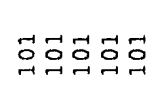 & ニㅗㅇㅛ & $\stackrel{n}{N}:$ & 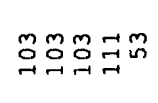 & $\infty=$ \\
\hline 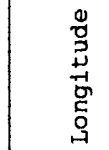 & 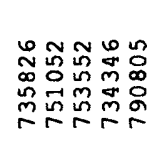 & 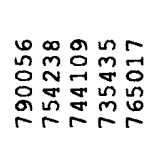 & 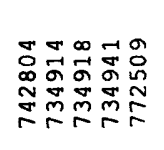 & 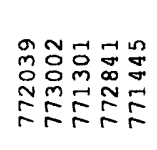 & 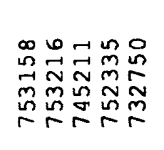 & 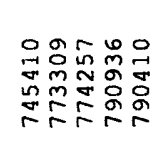 & 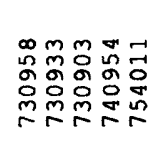 & 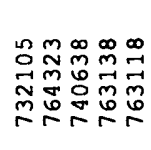 \\
\hline 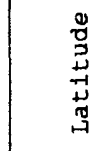 & 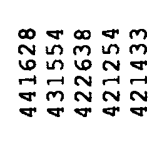 & 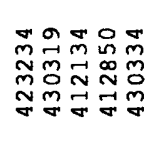 & 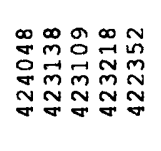 & 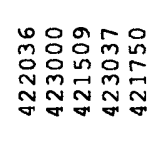 & 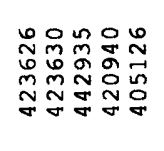 & 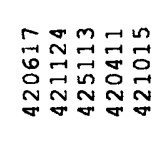 & 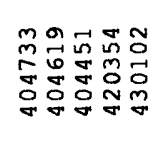 & 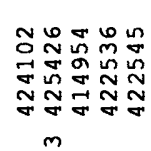 \\
\hline 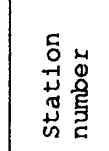 & 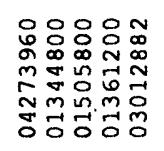 & 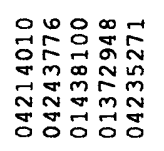 & 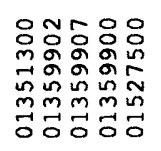 & 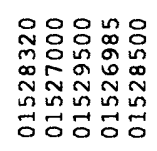 & 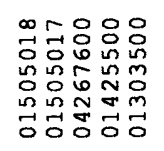 & 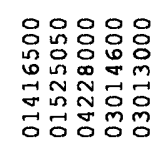 & 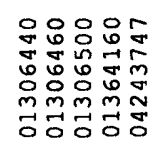 & 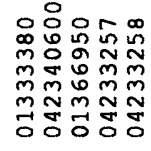 \\
\hline 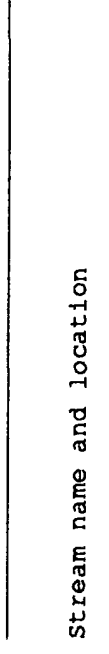 & 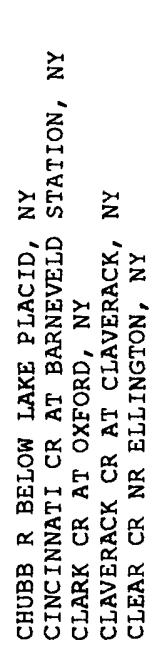 & 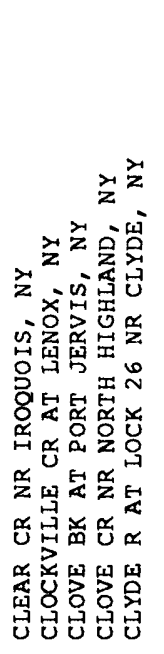 & 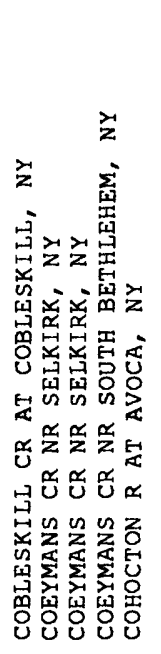 & 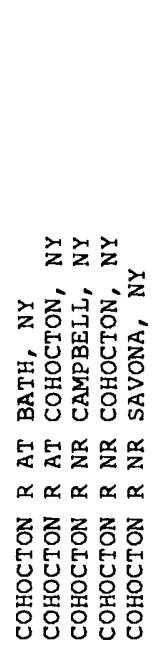 & 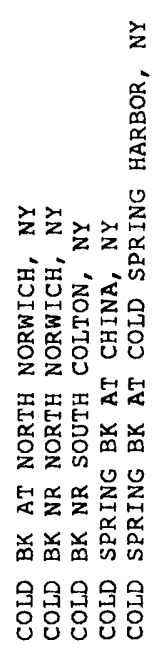 & 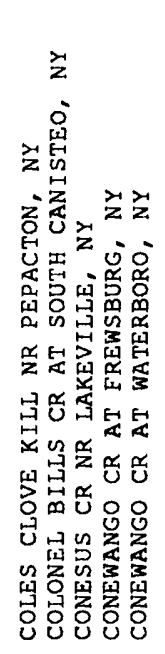 & 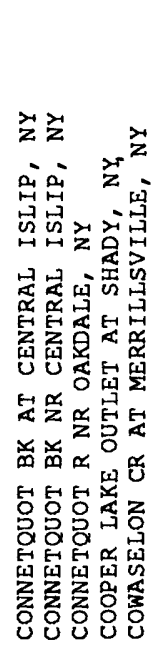 & 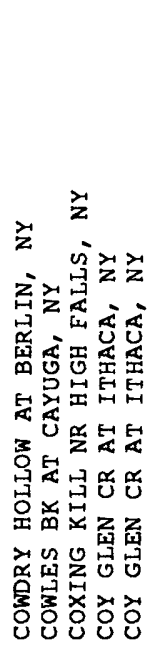 \\
\hline
\end{tabular}




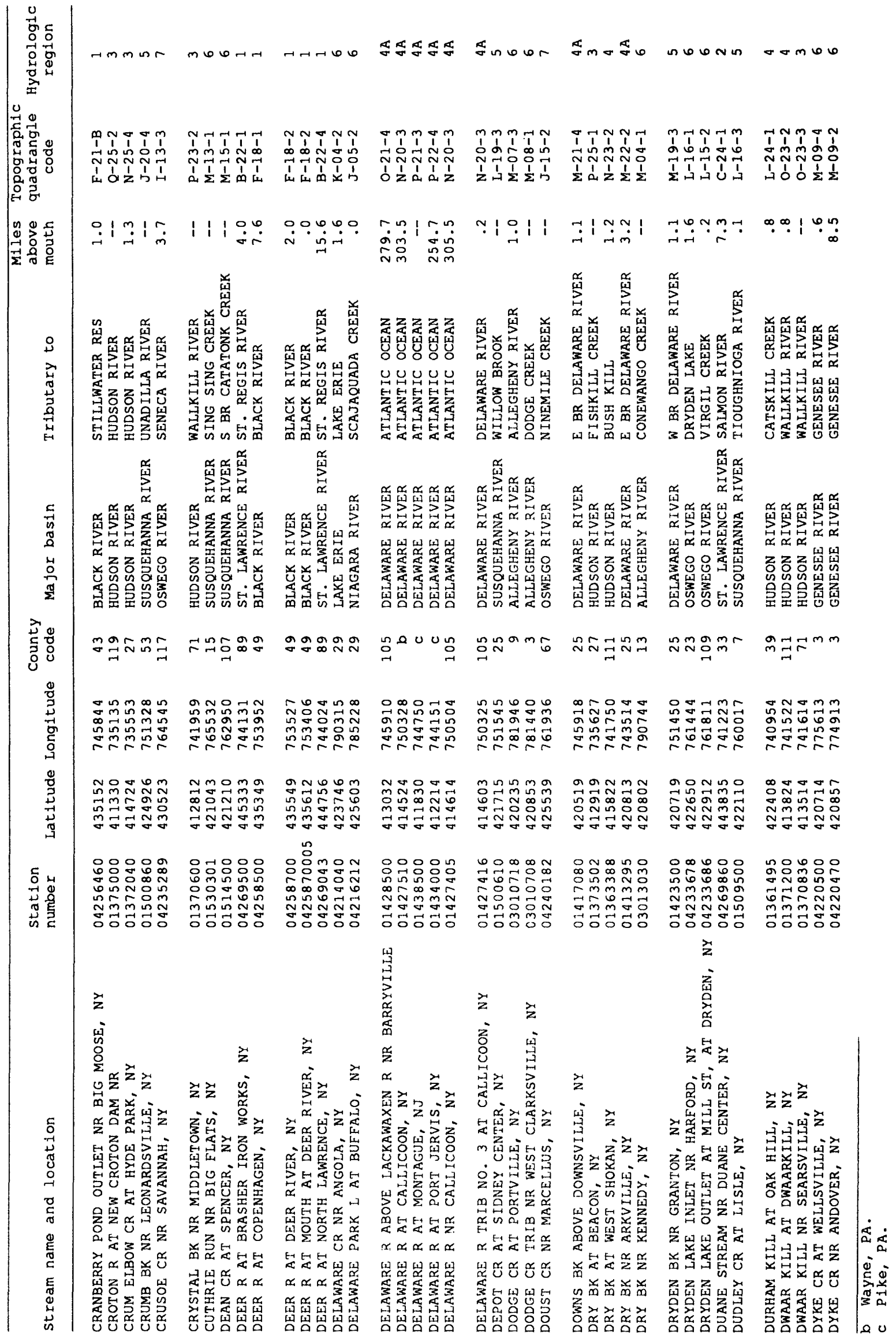




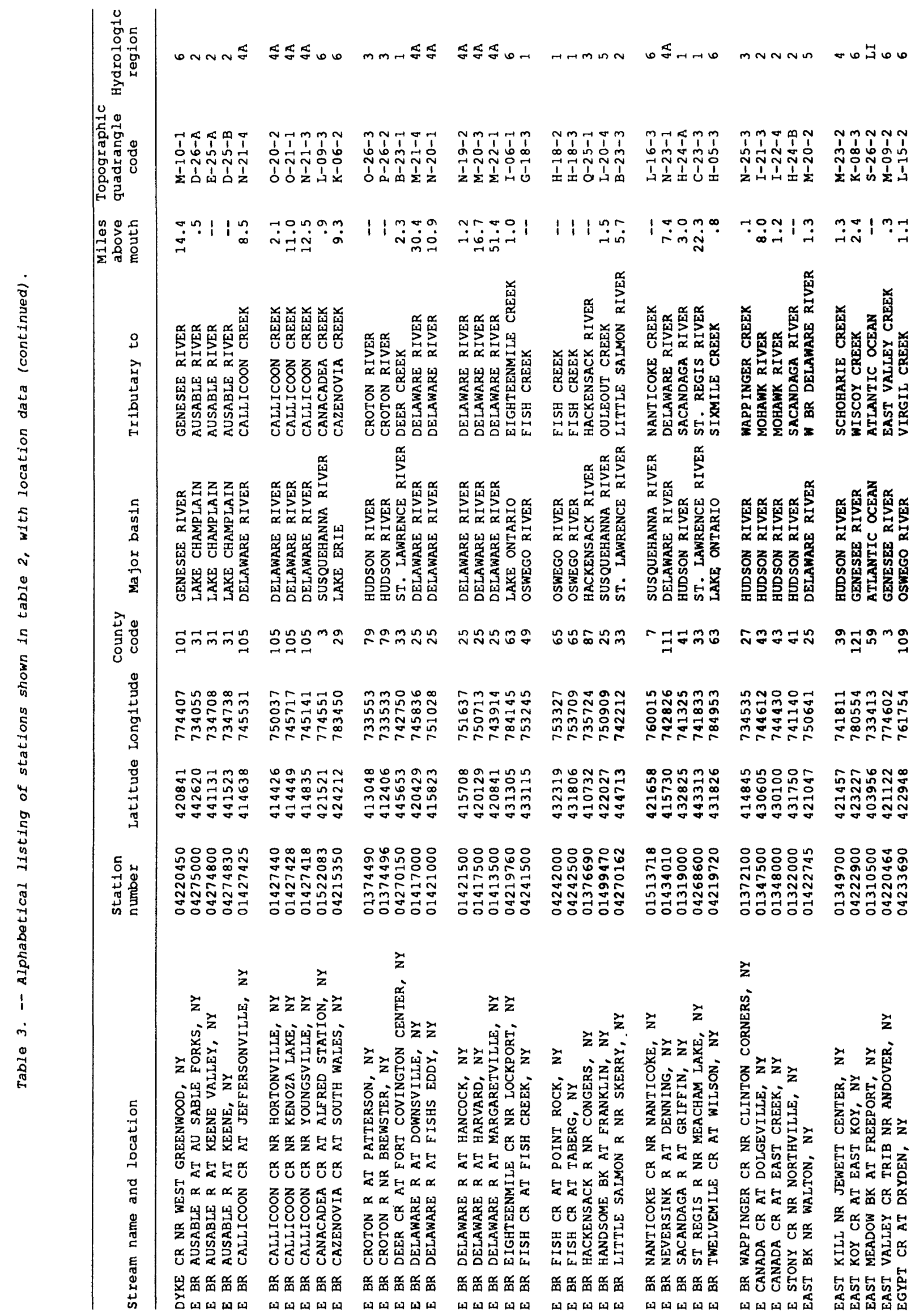




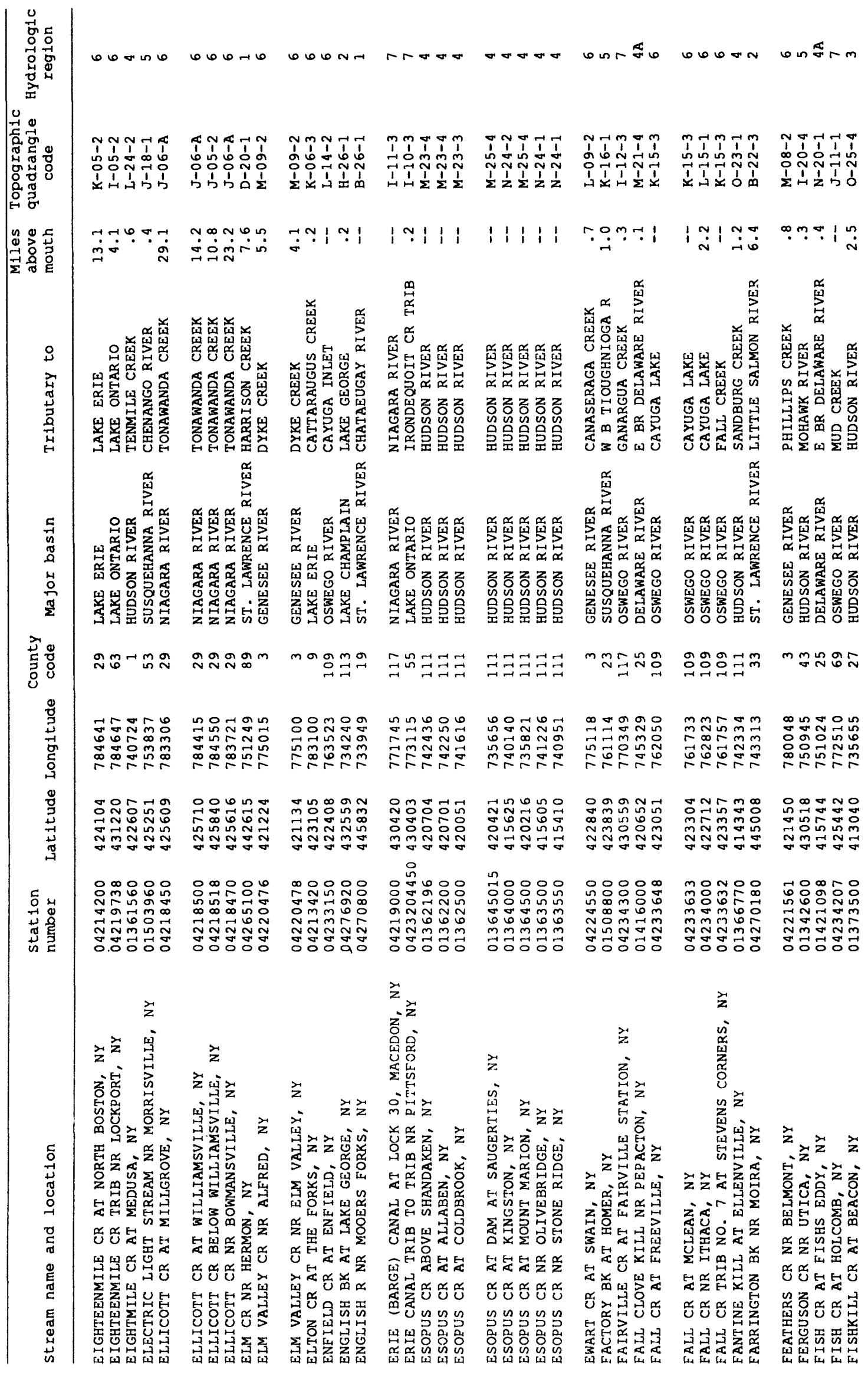




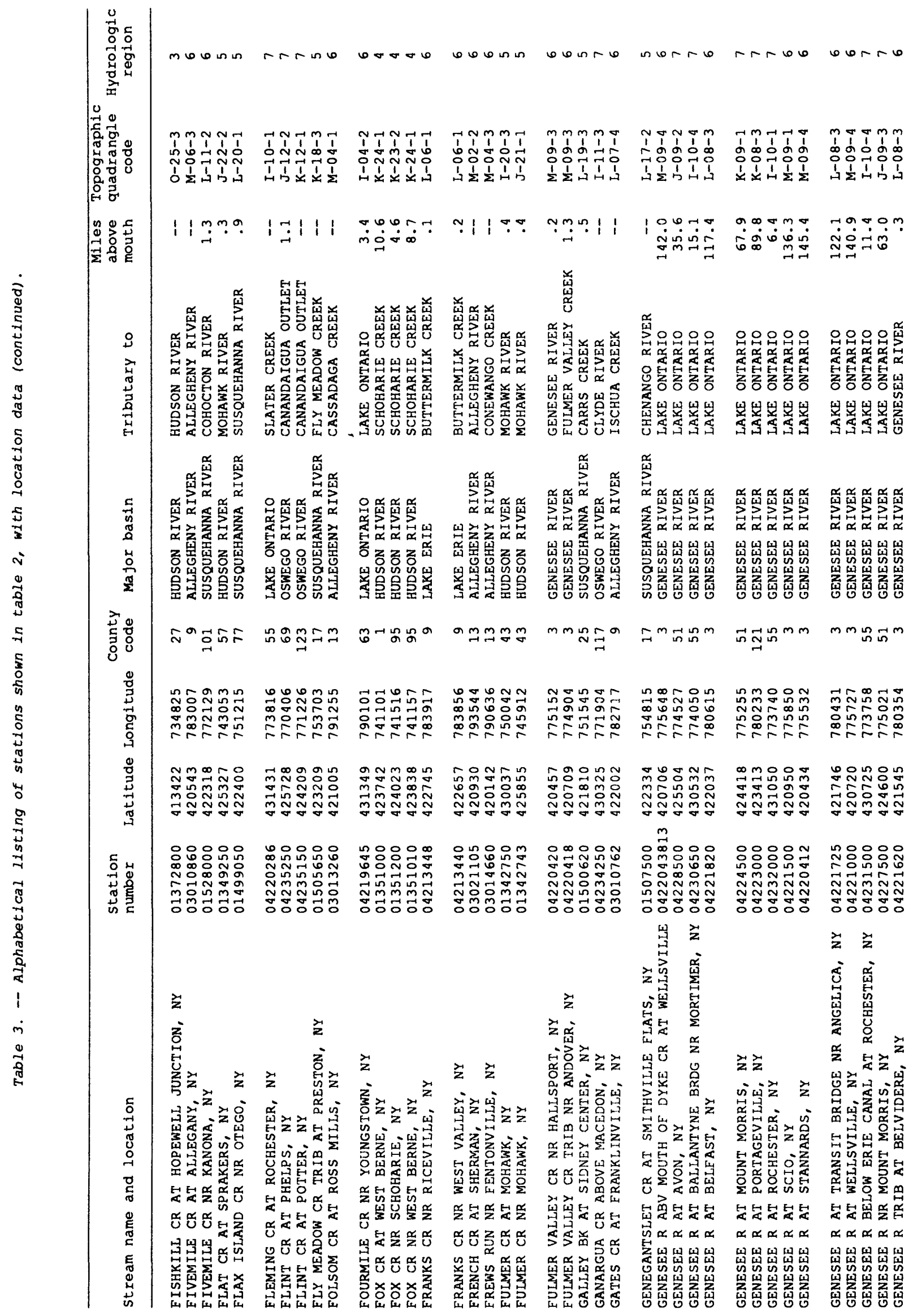




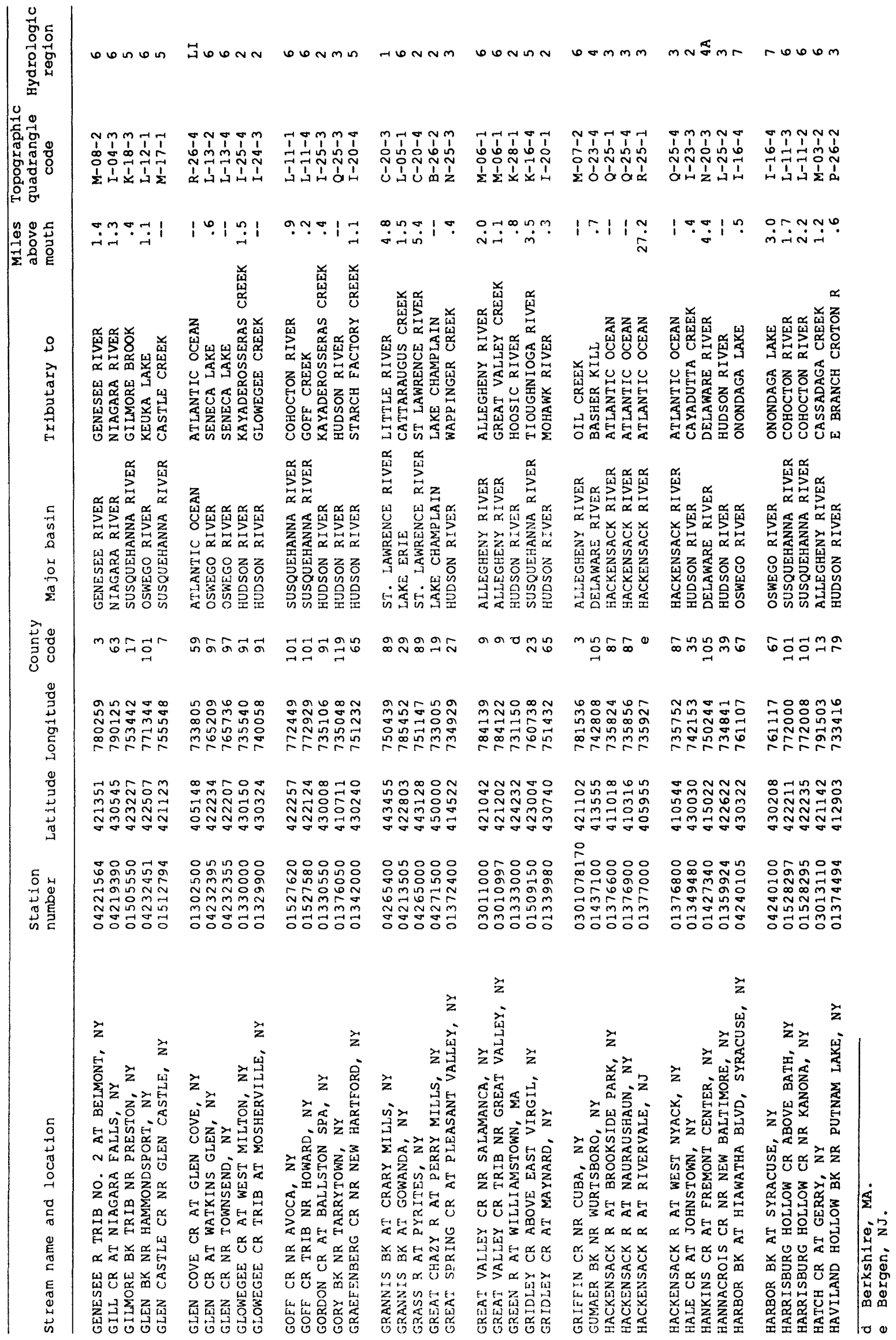




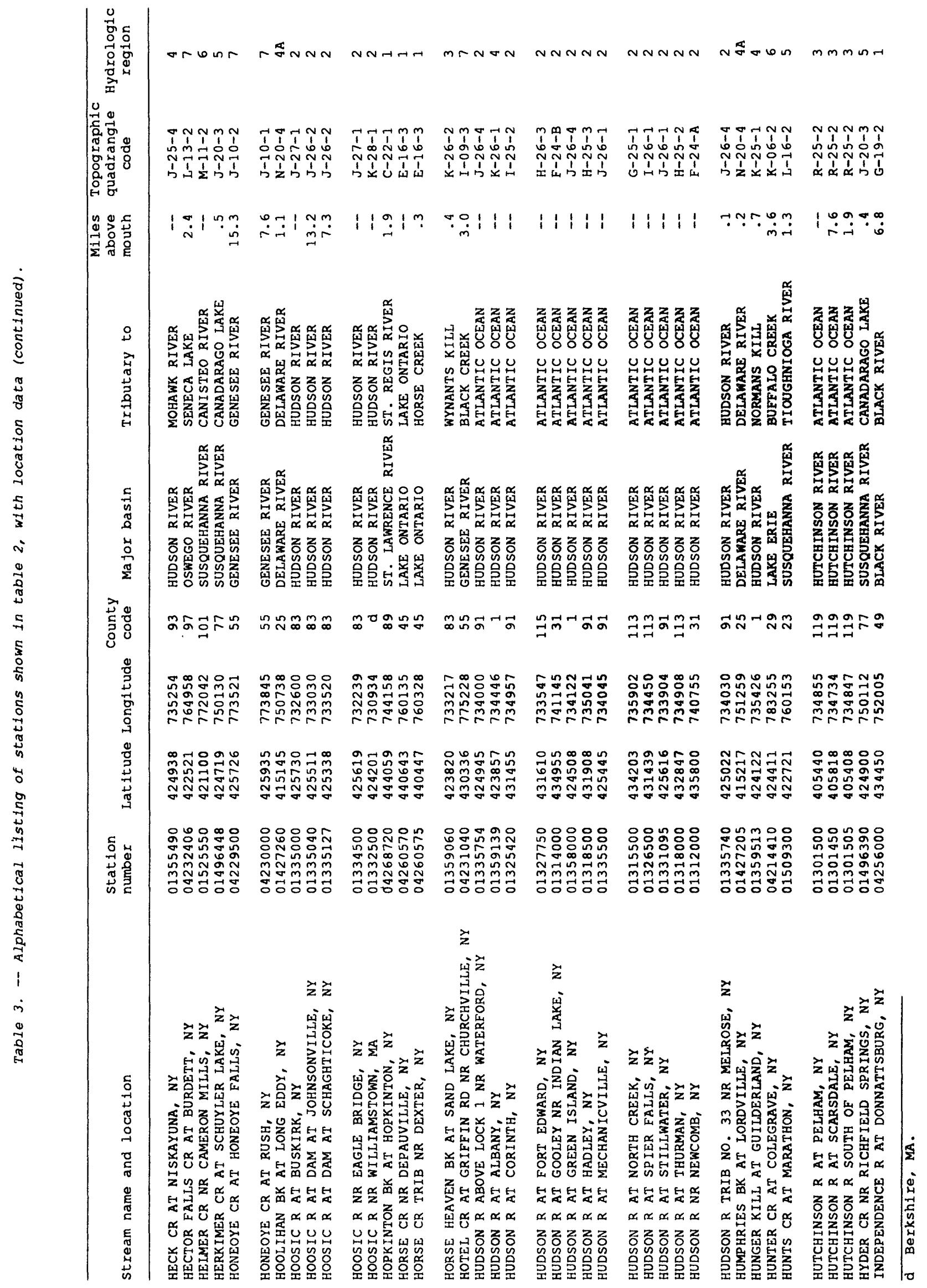




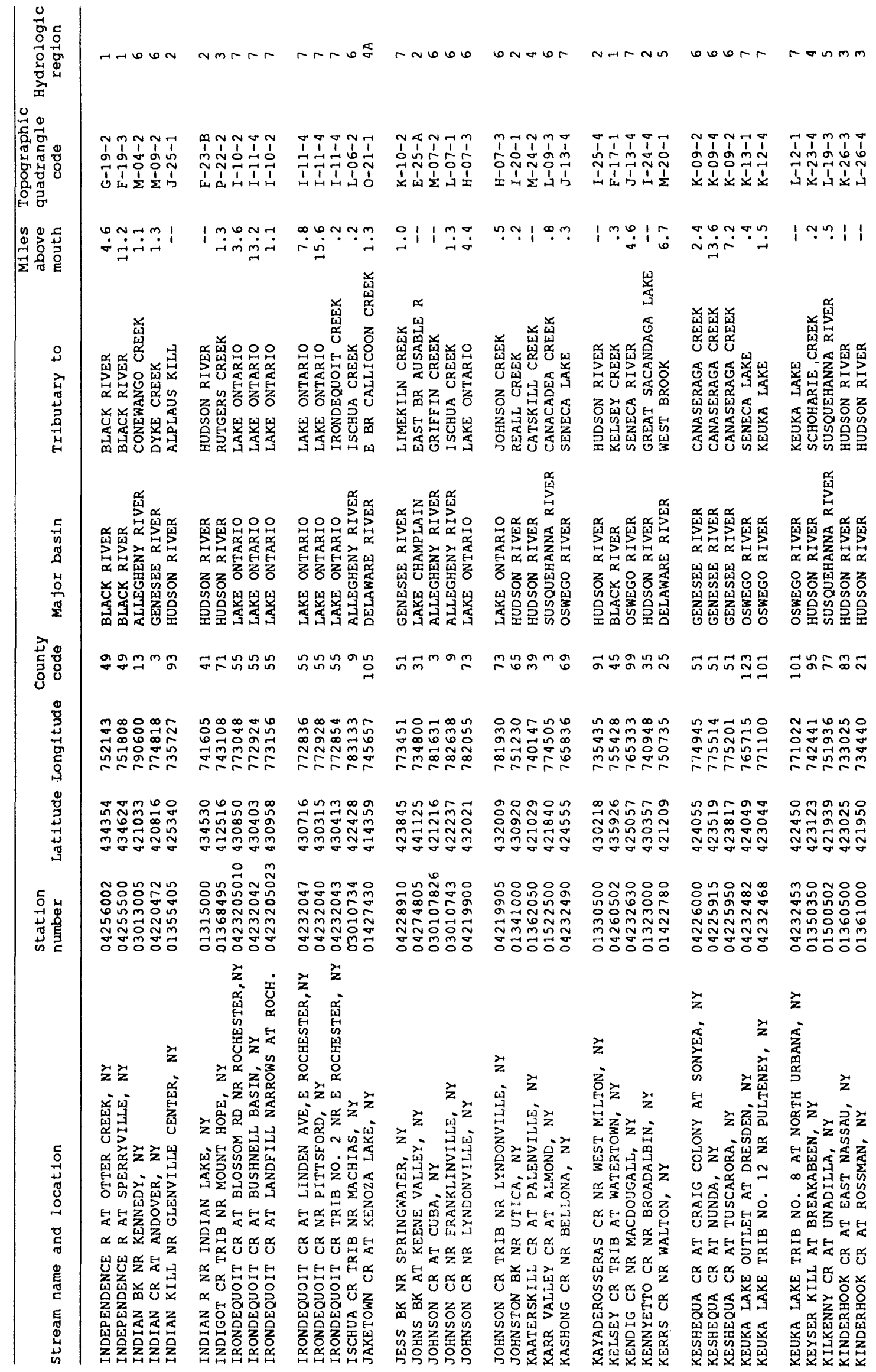




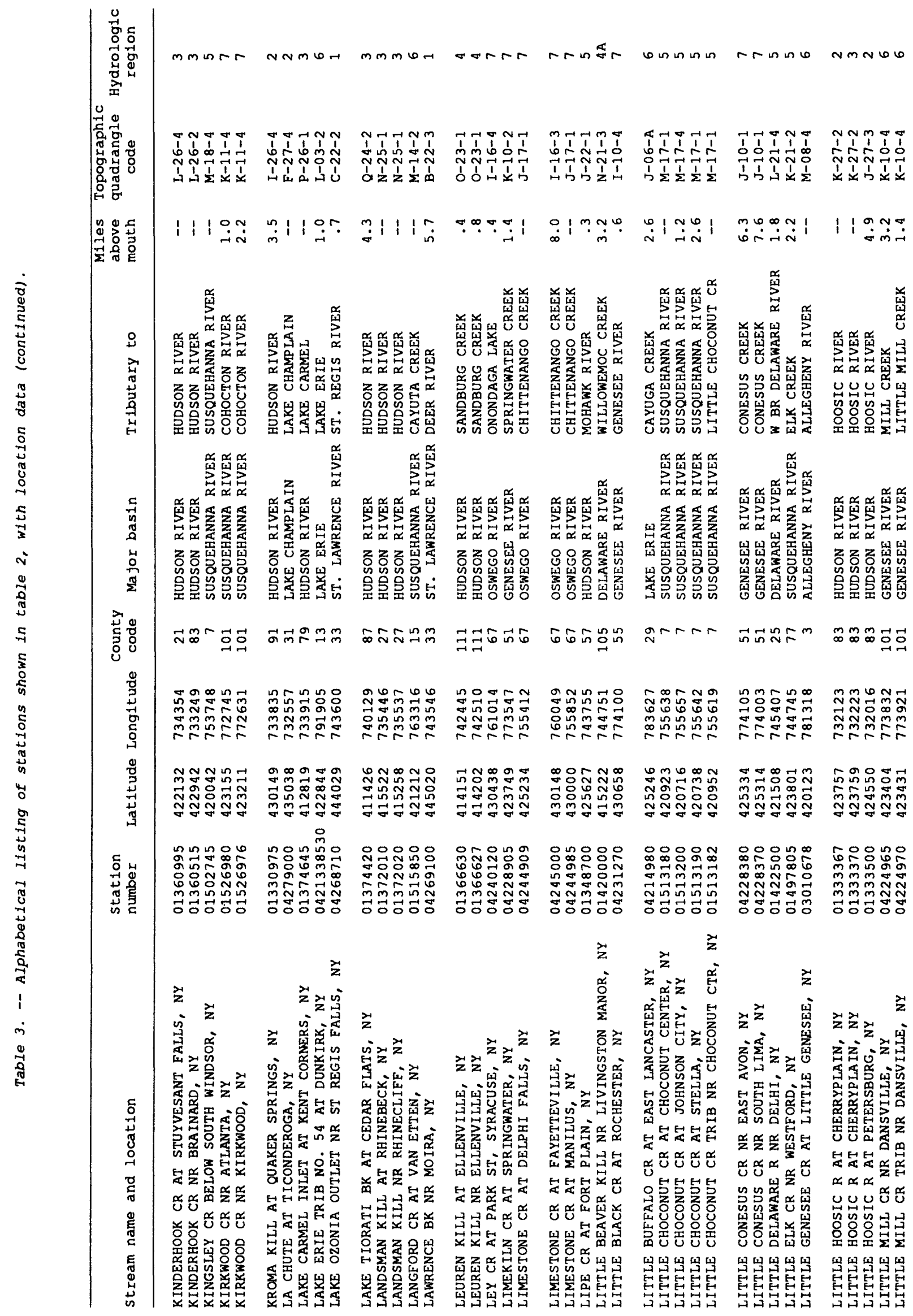




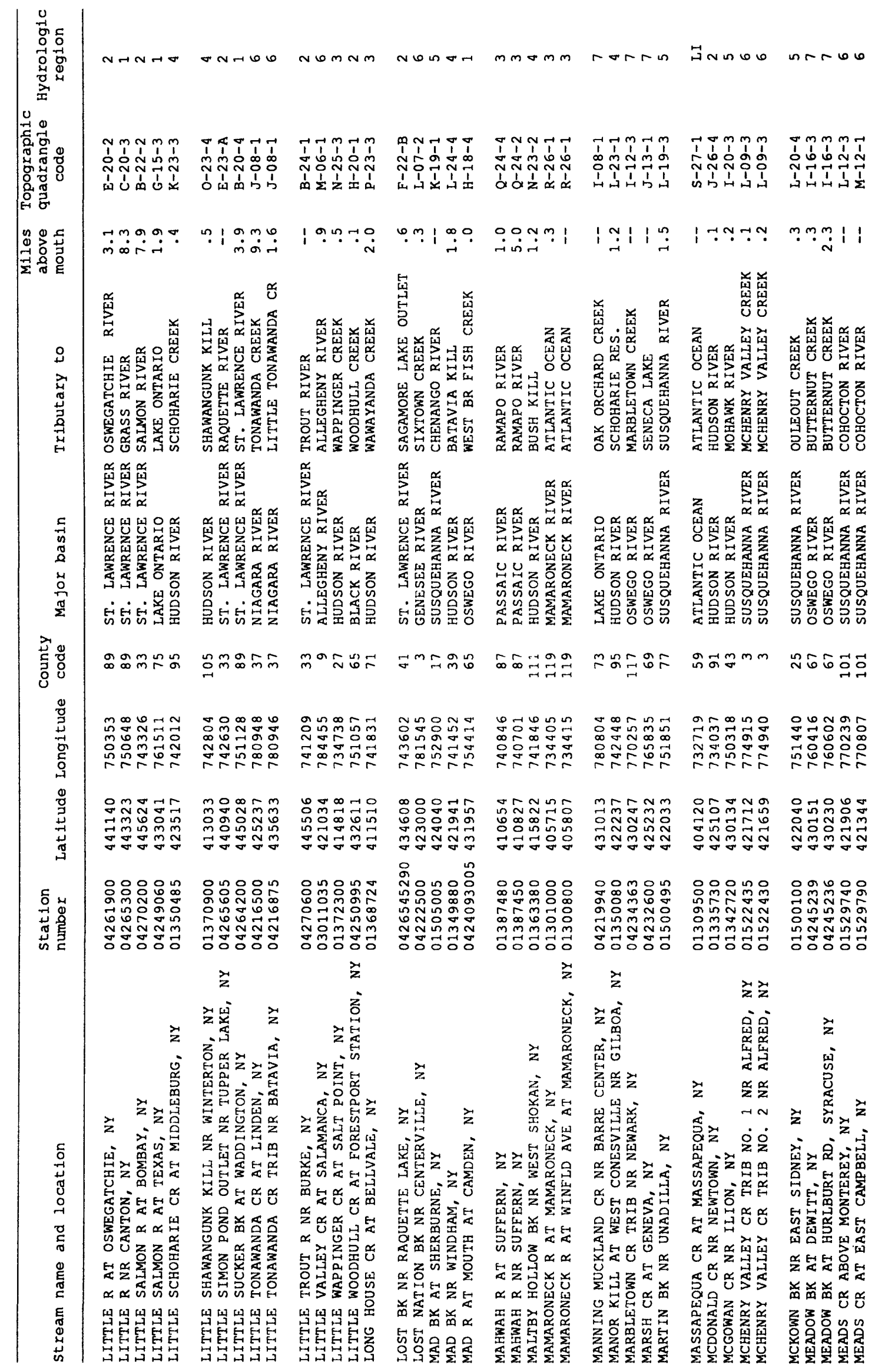




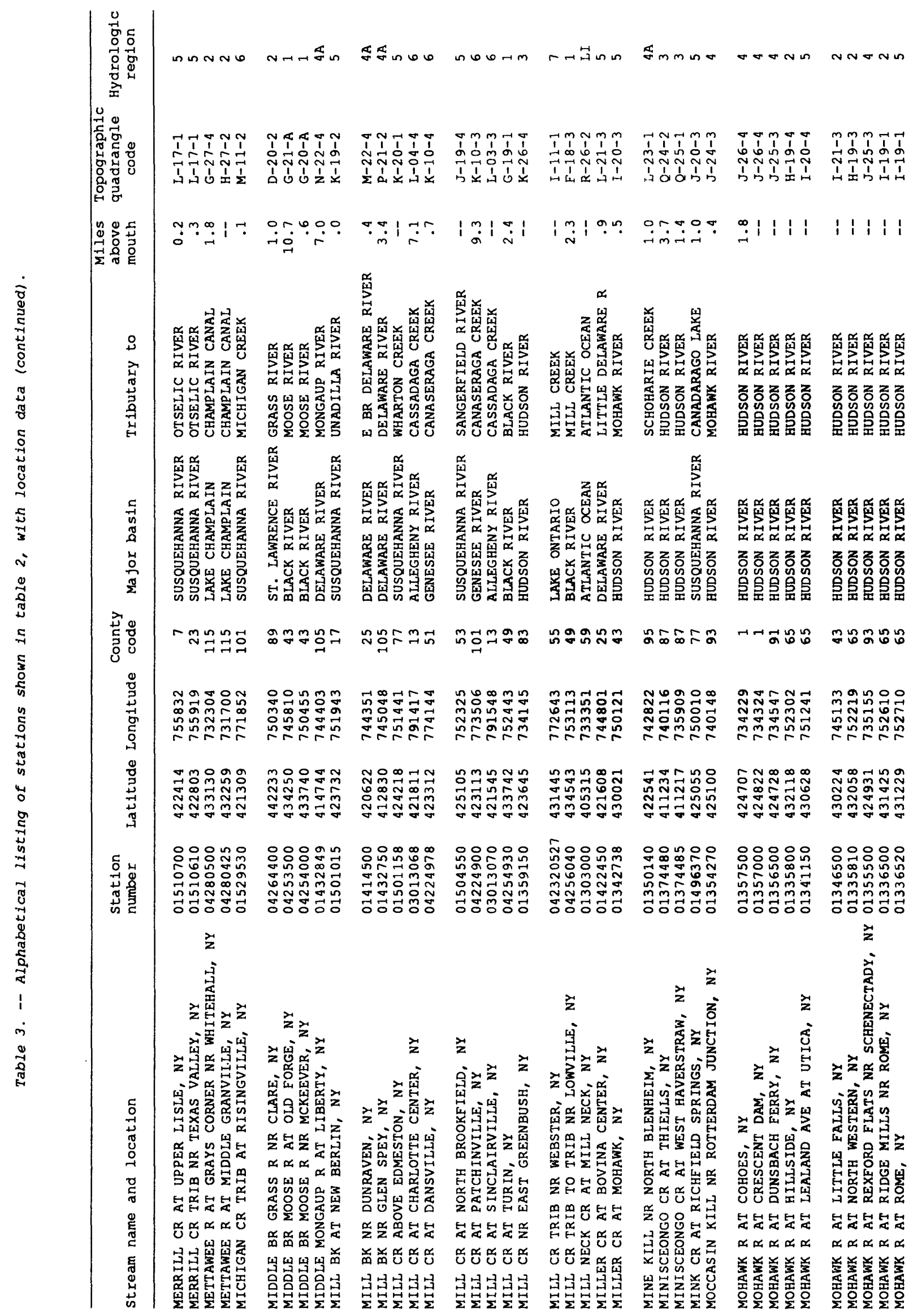




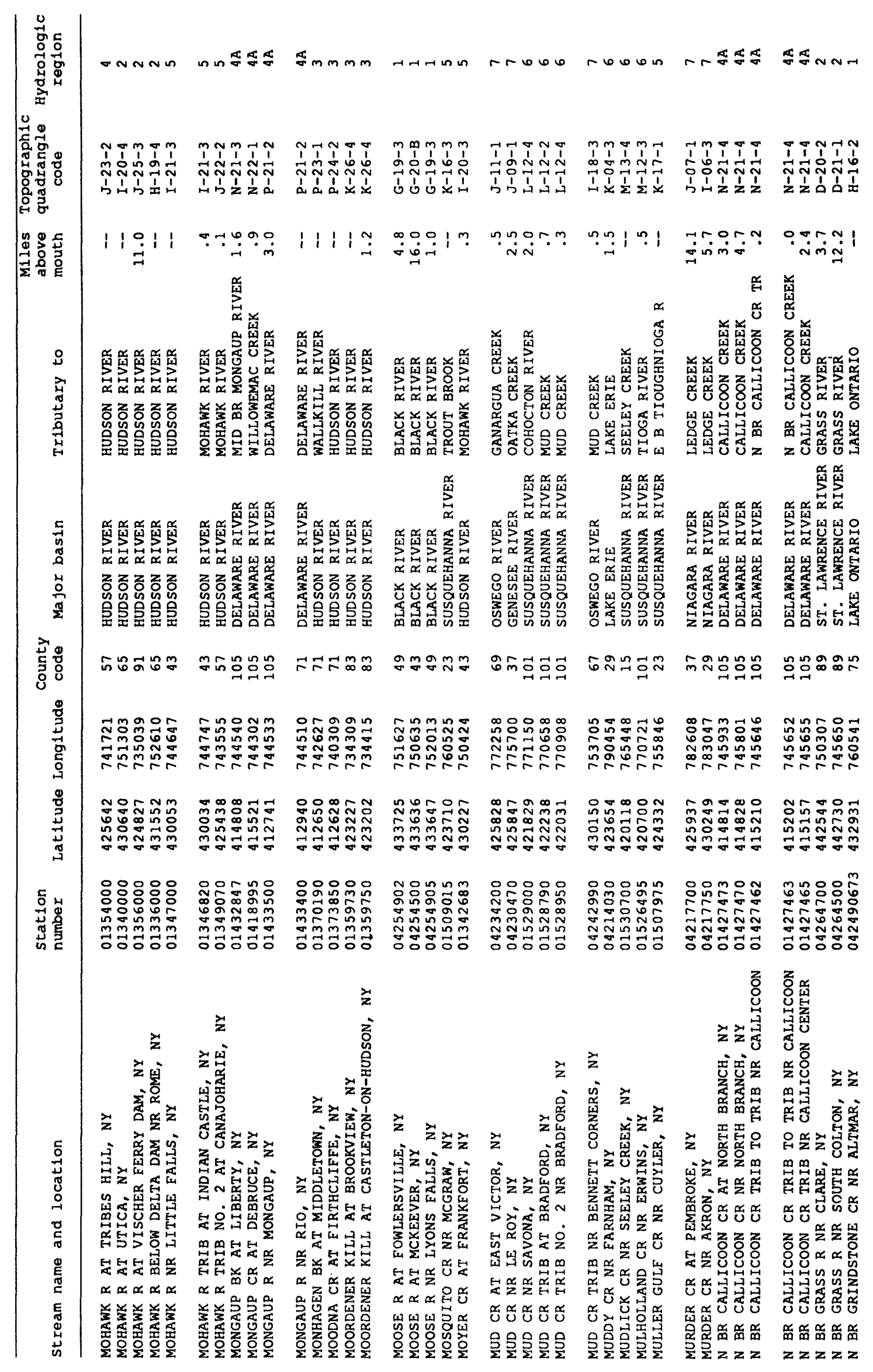




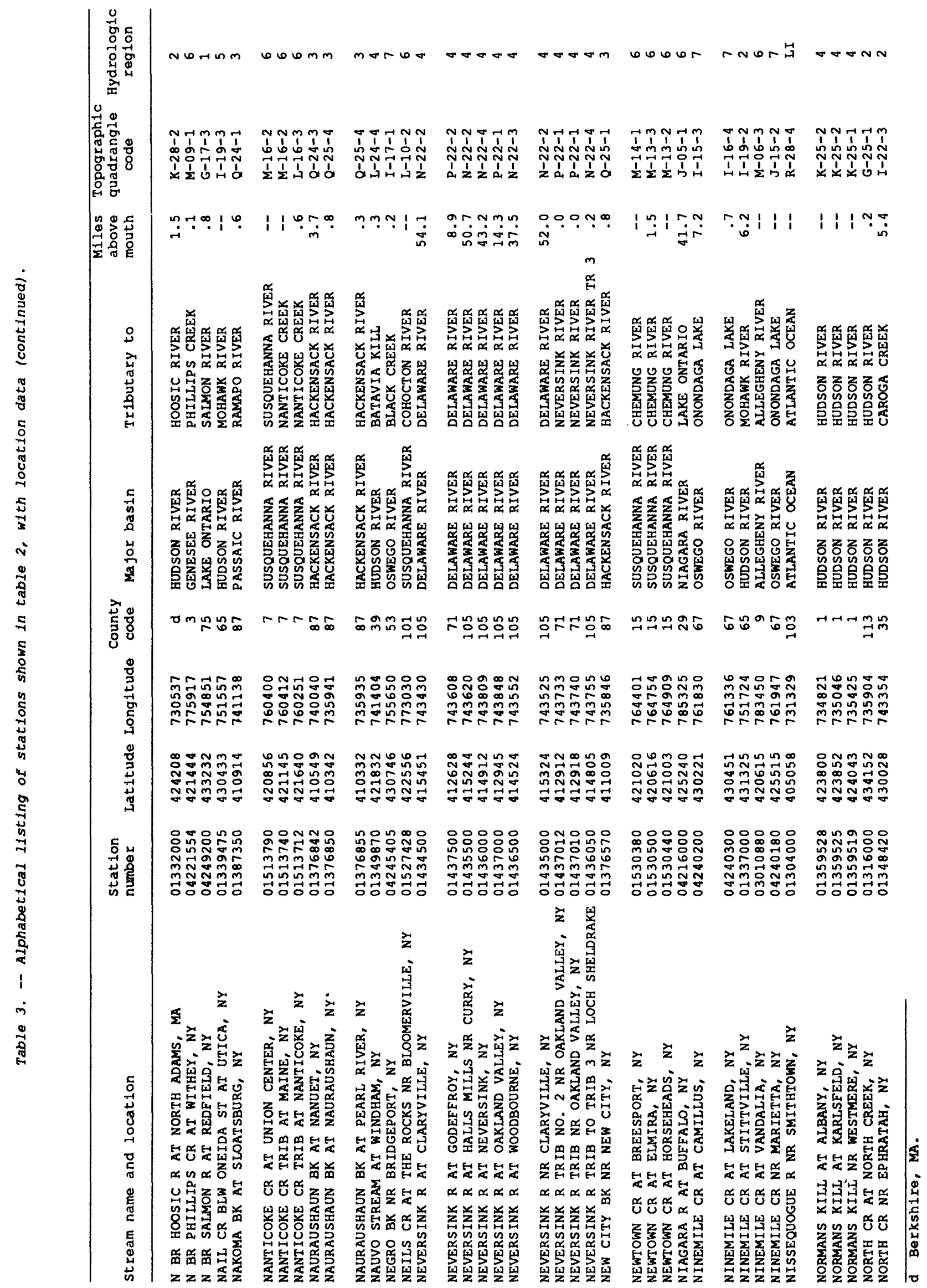




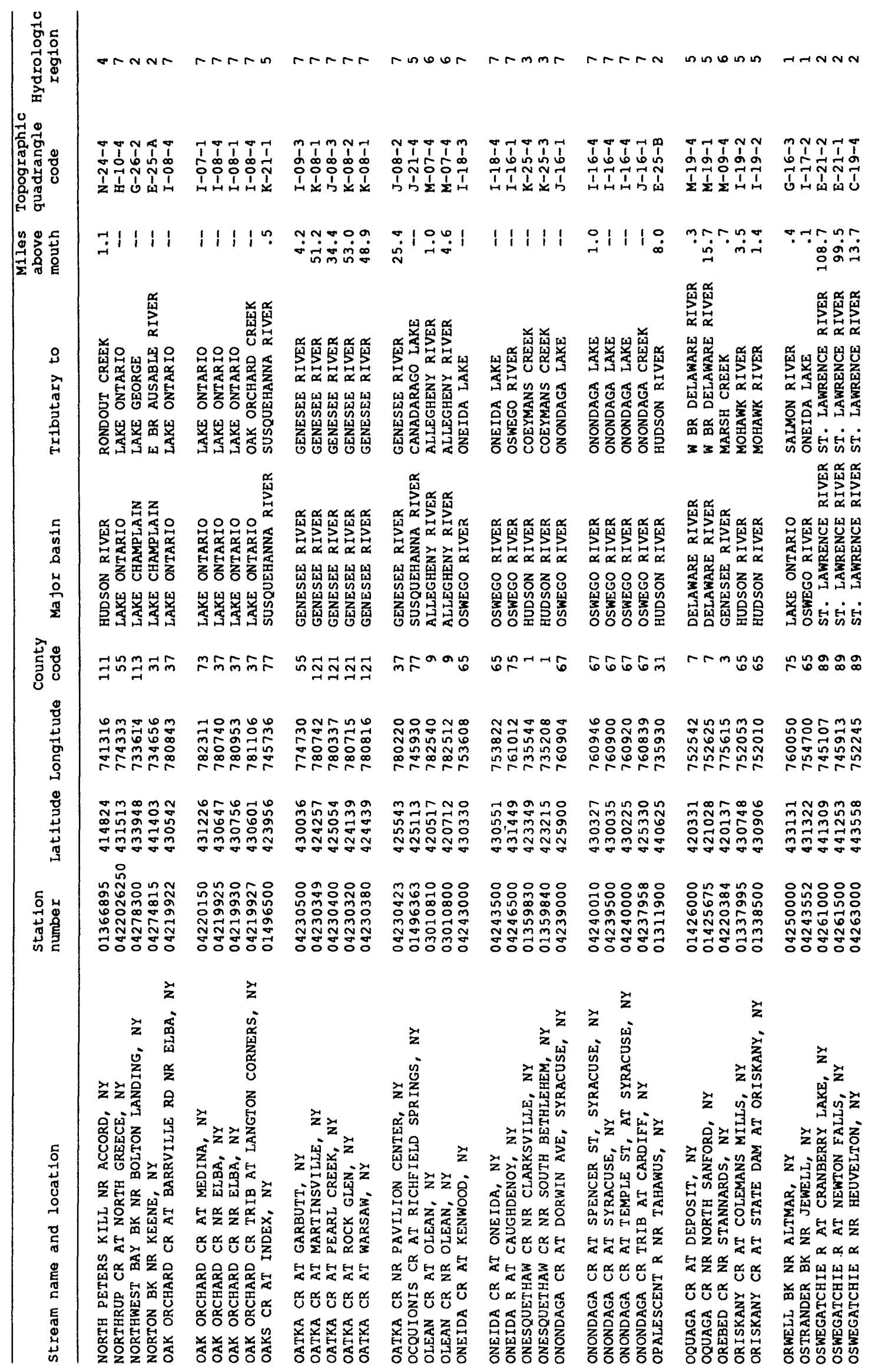




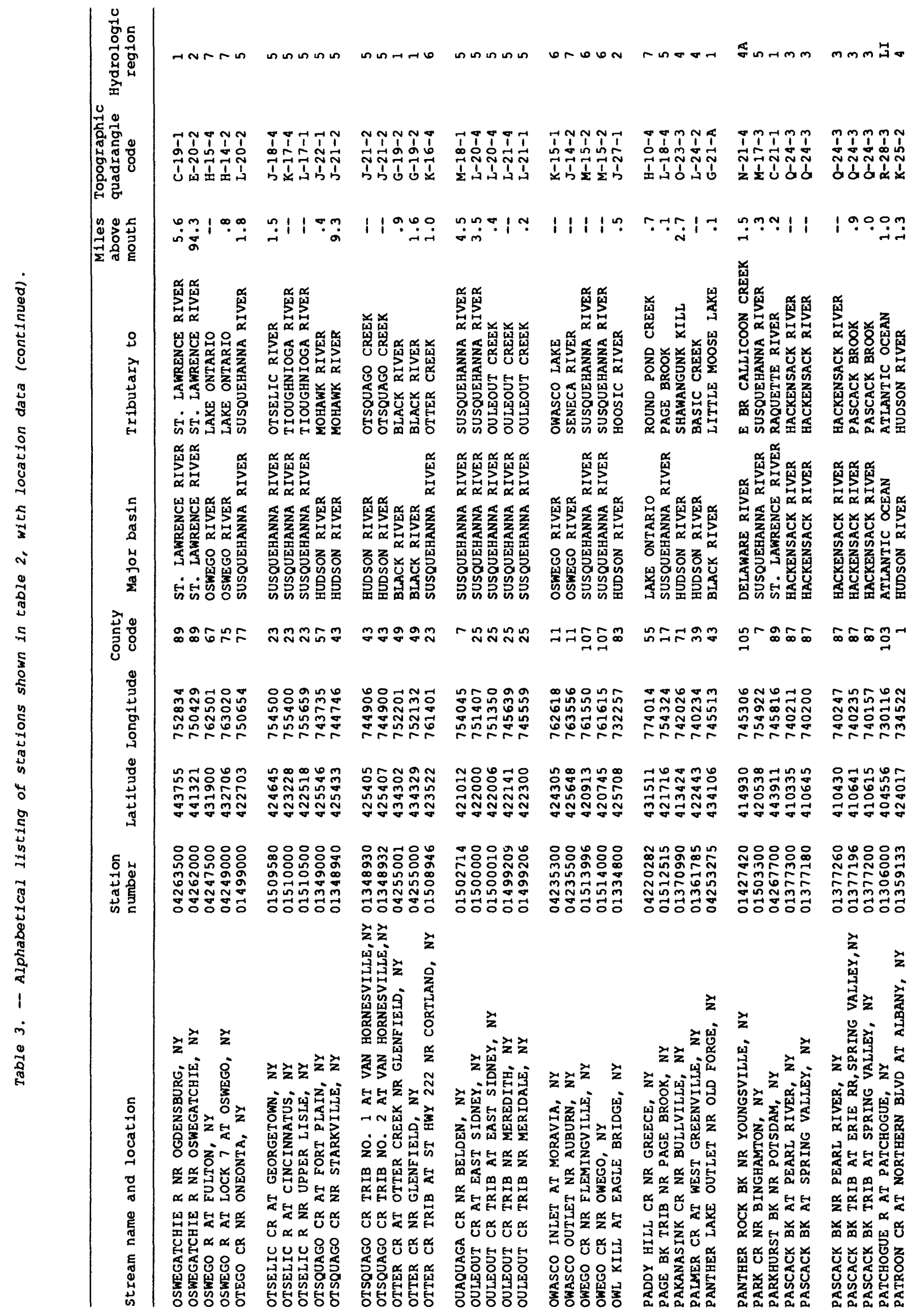




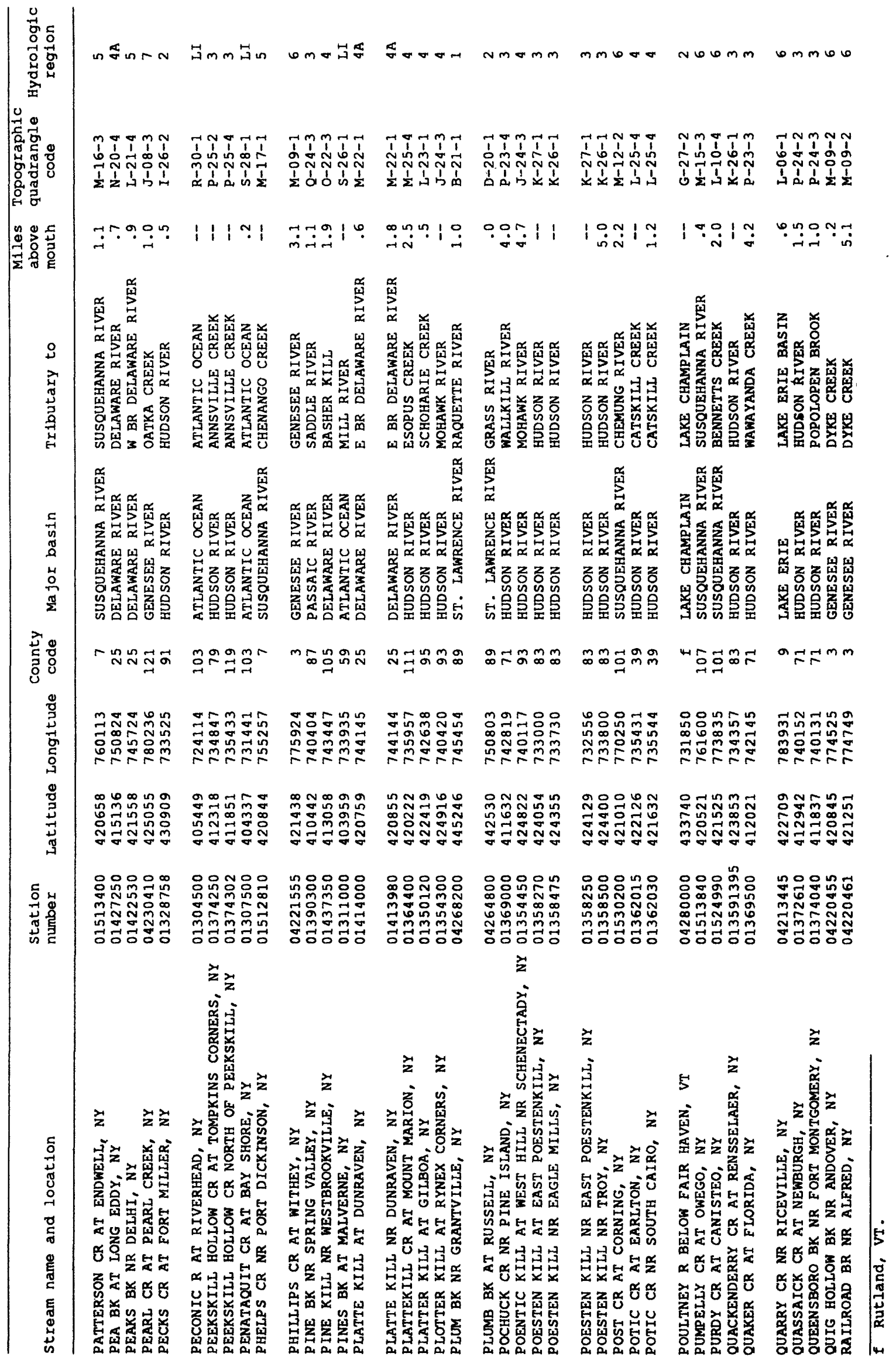




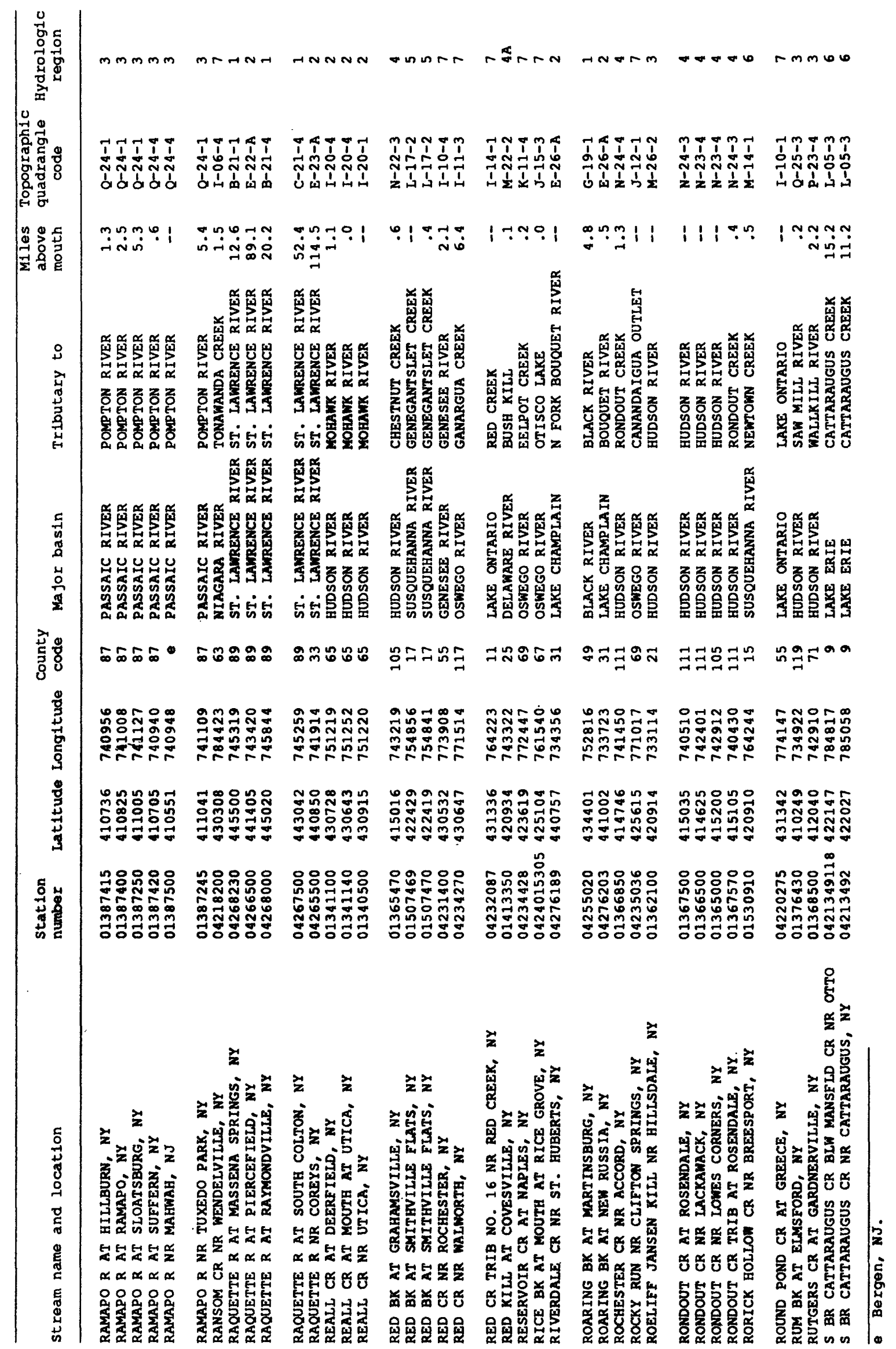




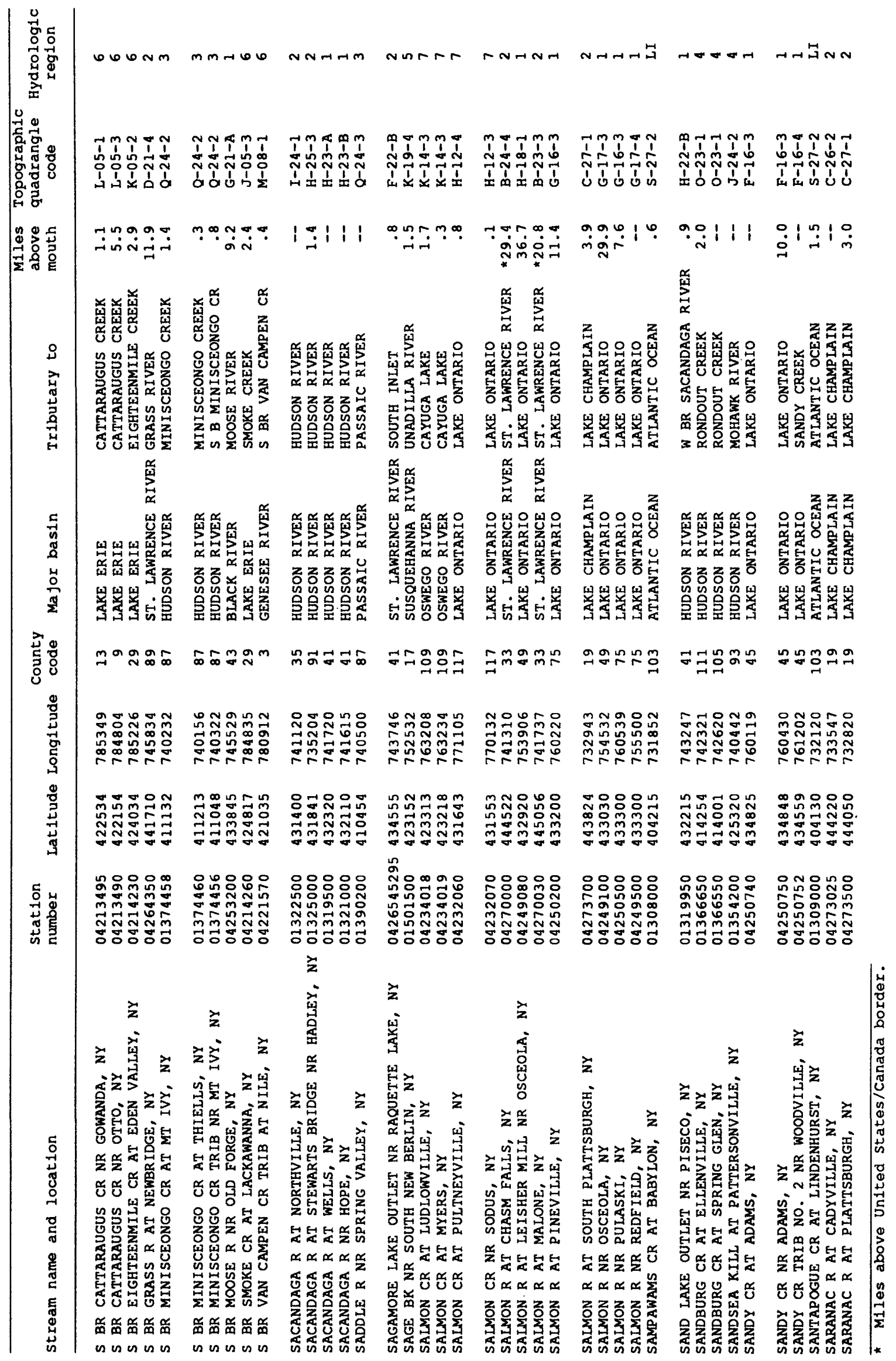




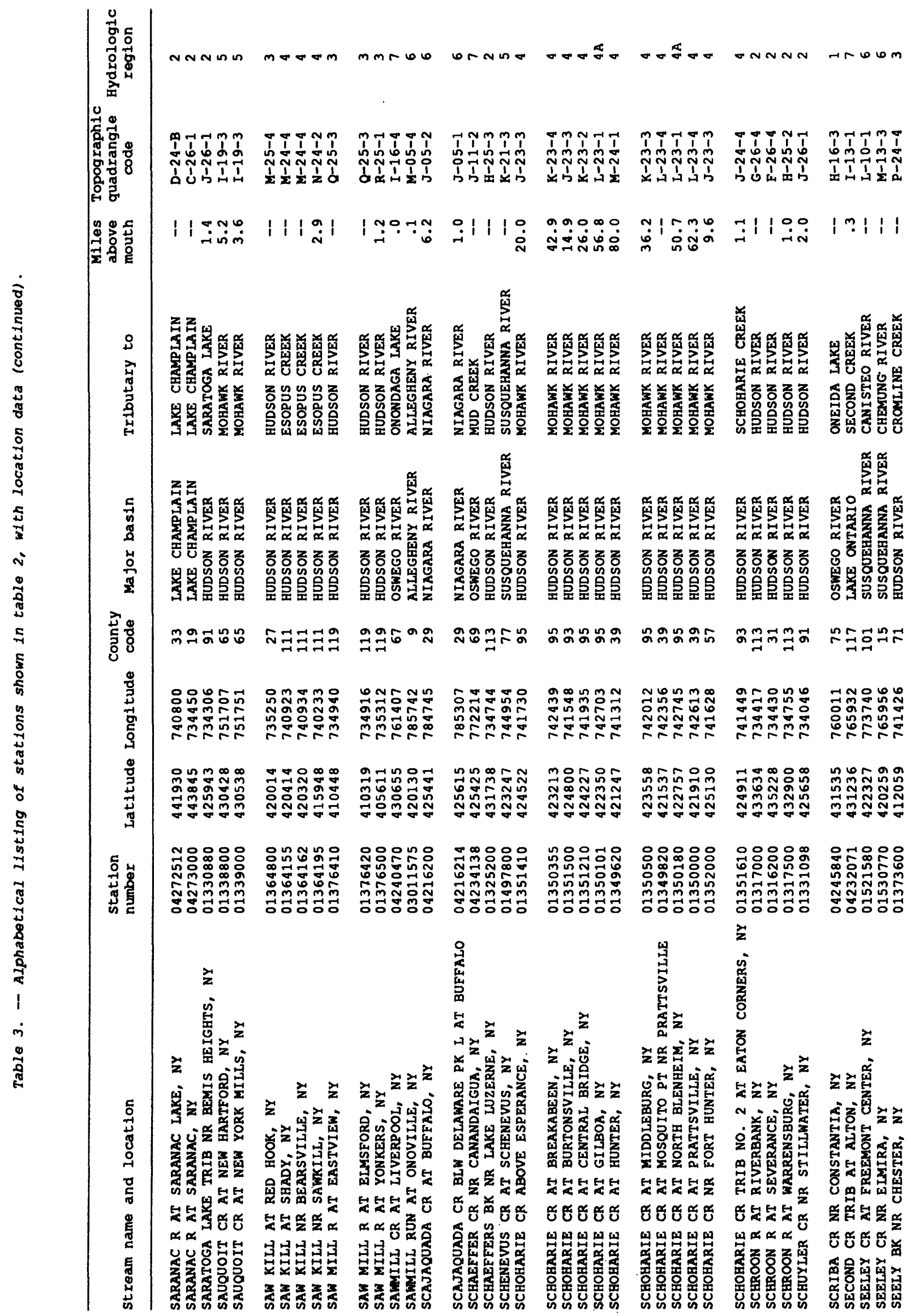




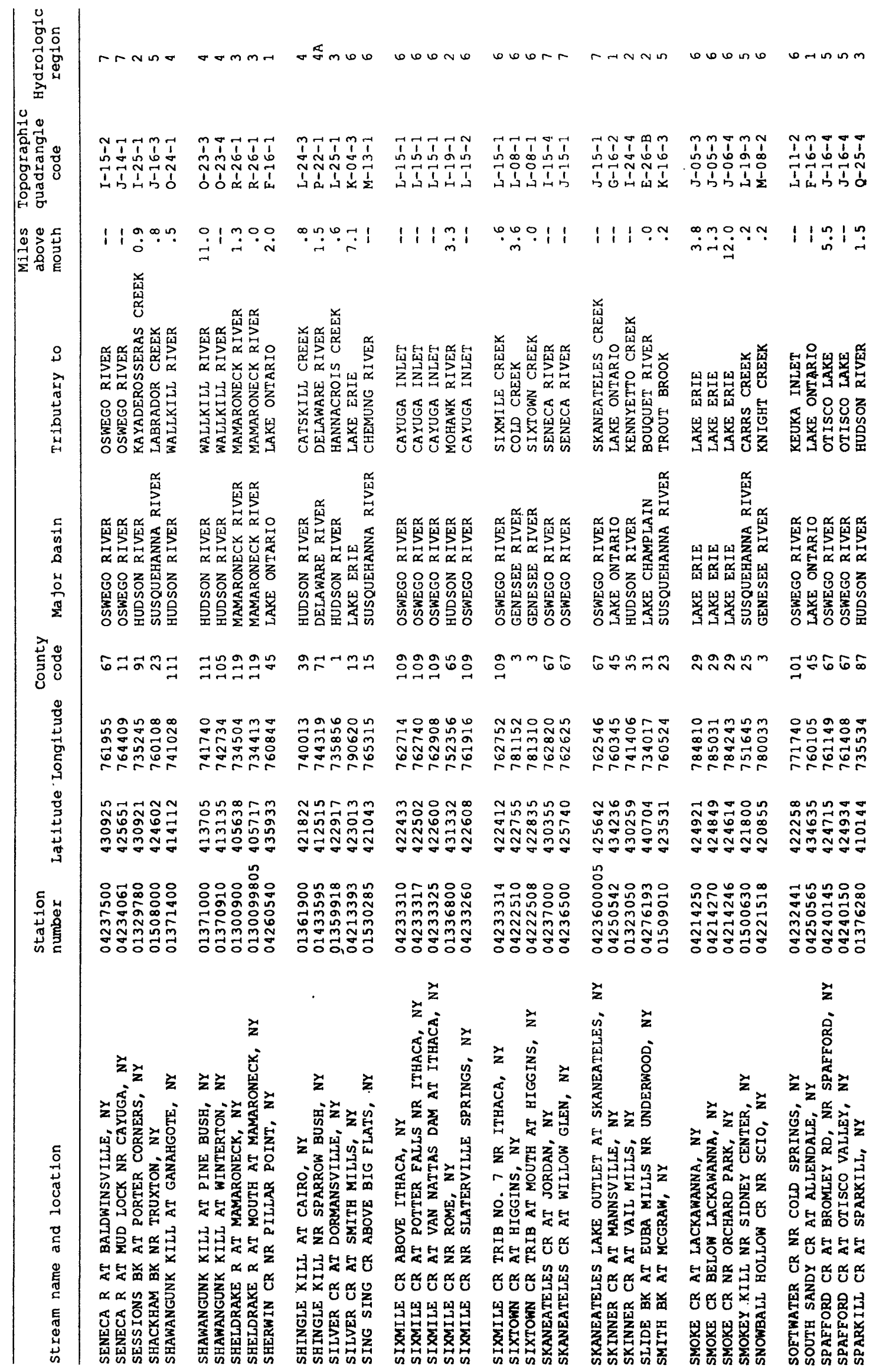




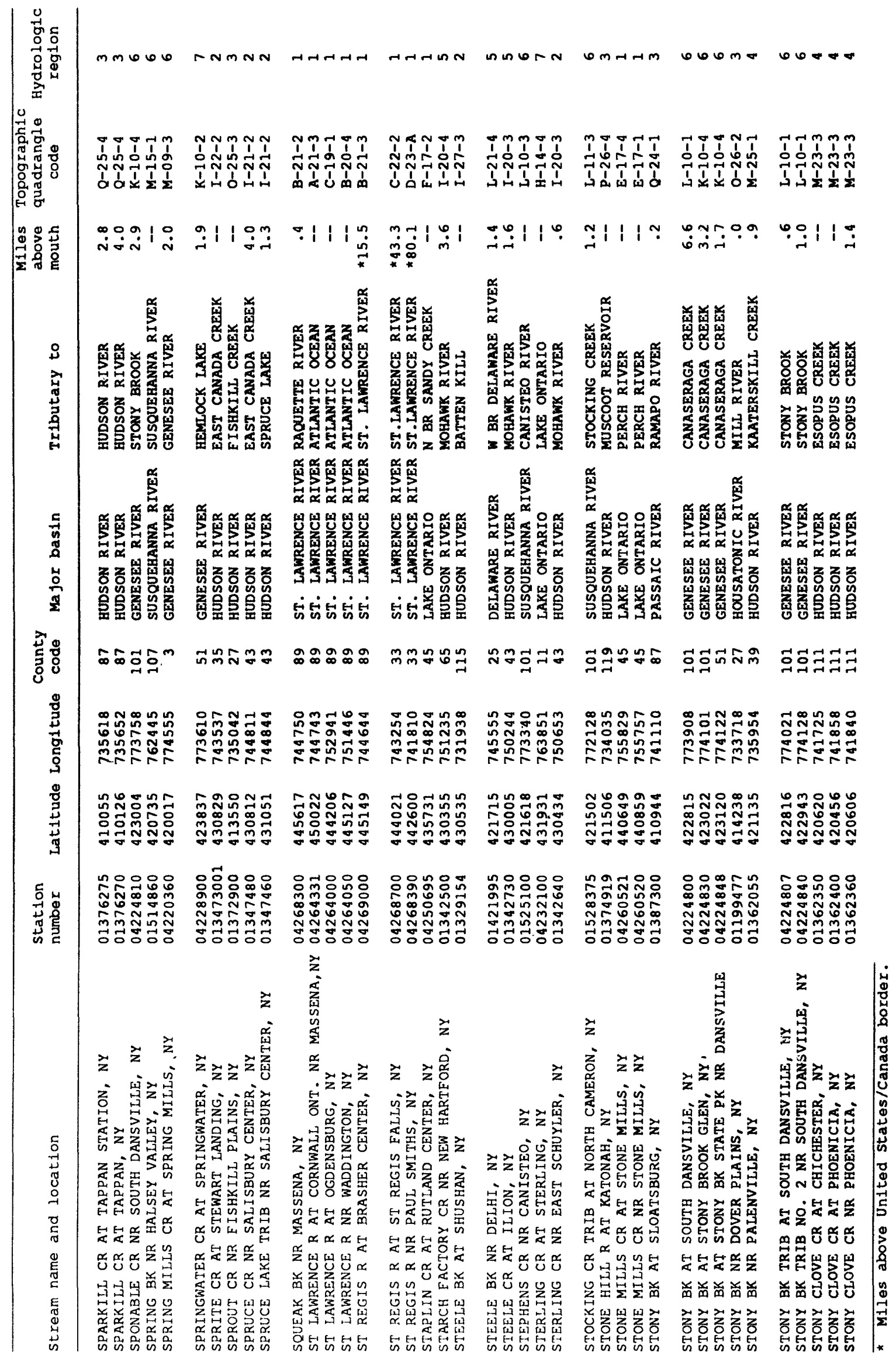




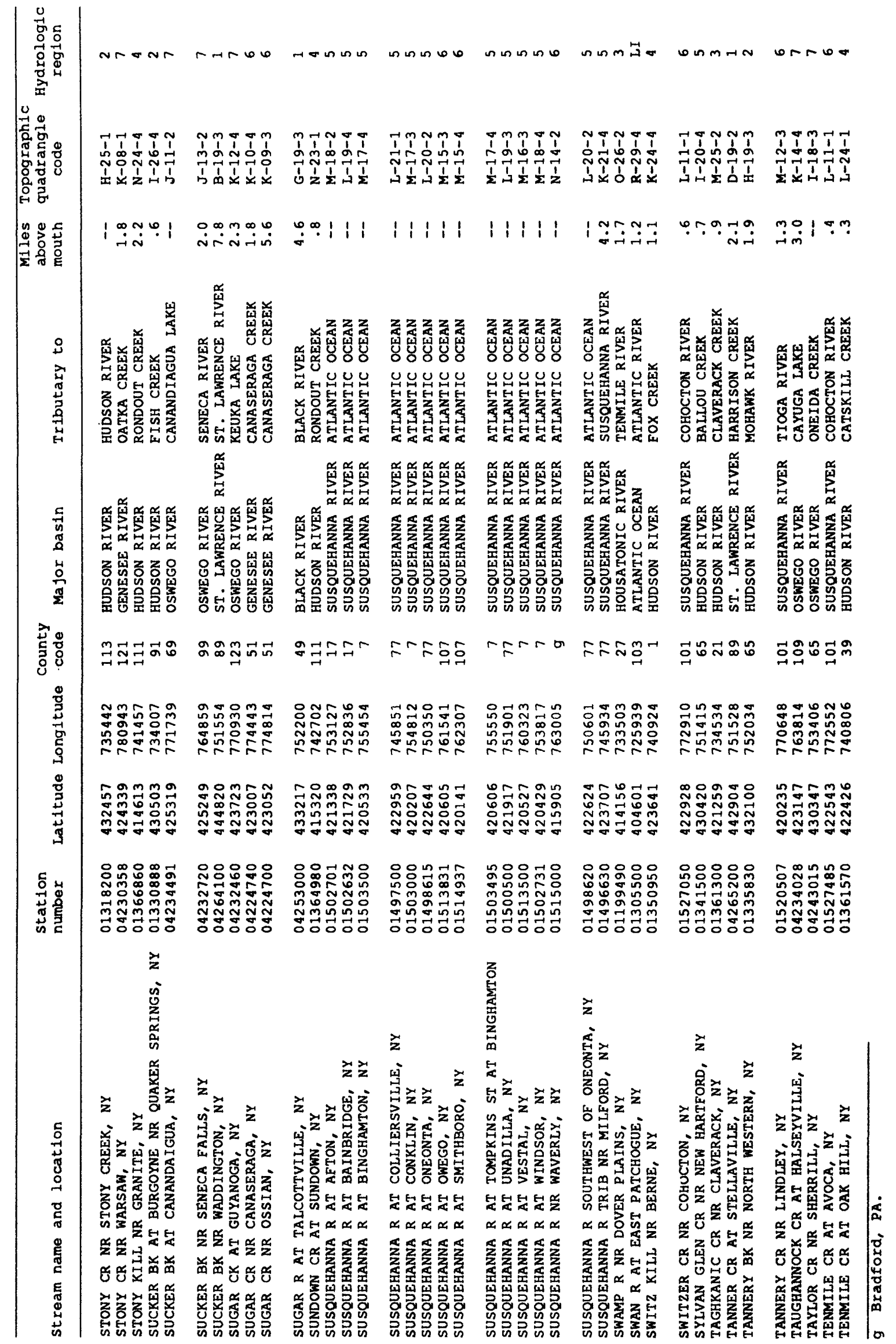




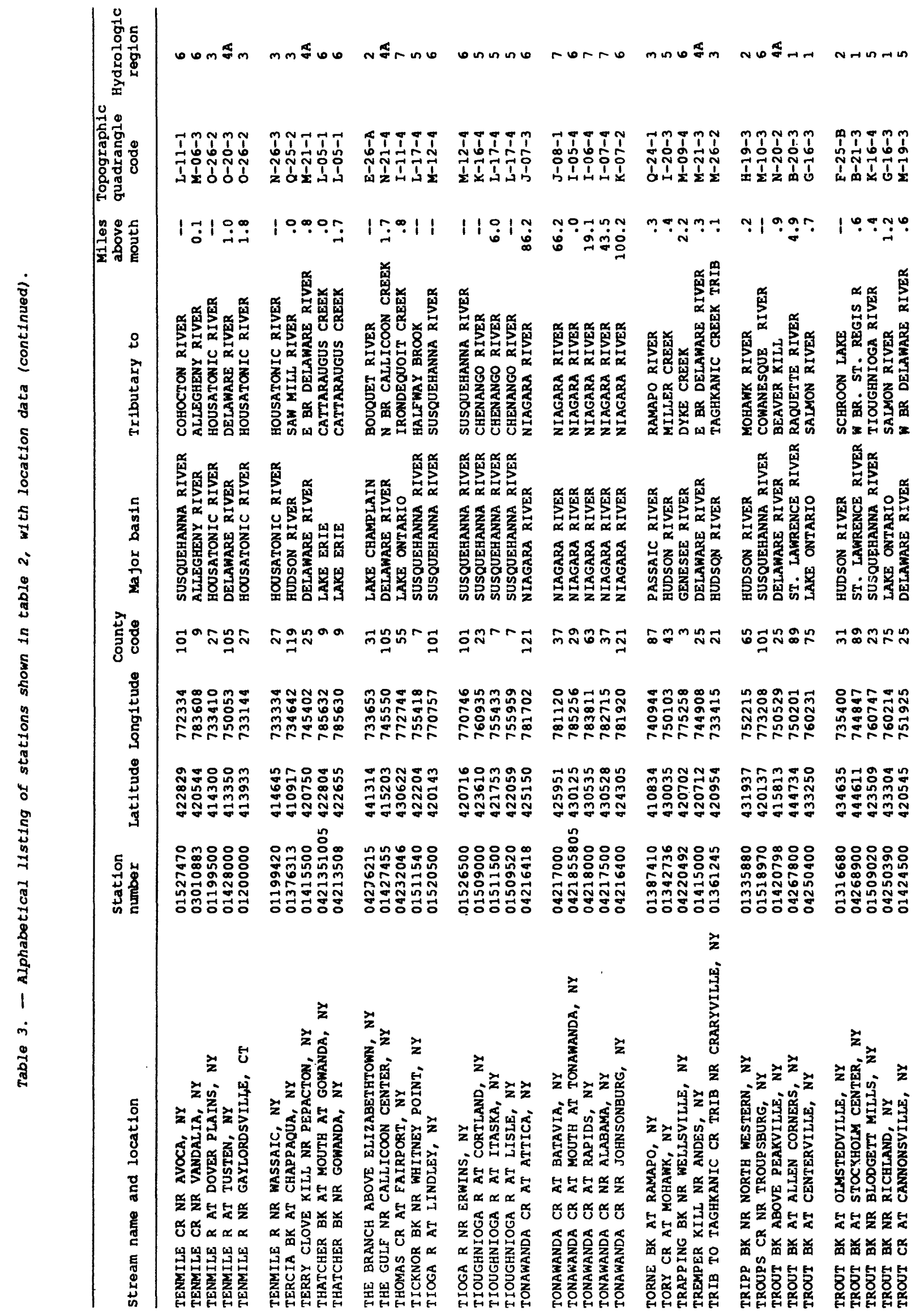




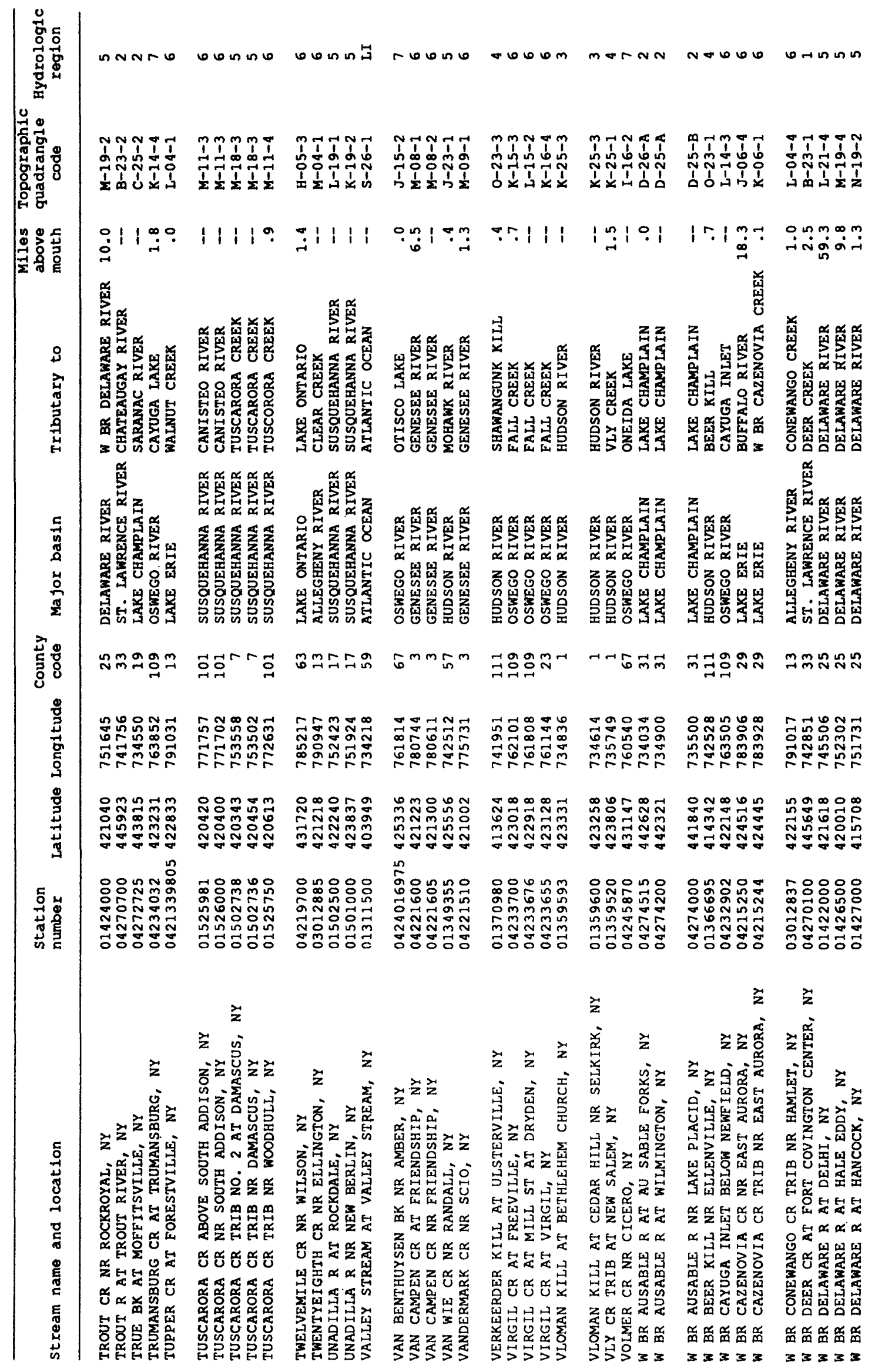




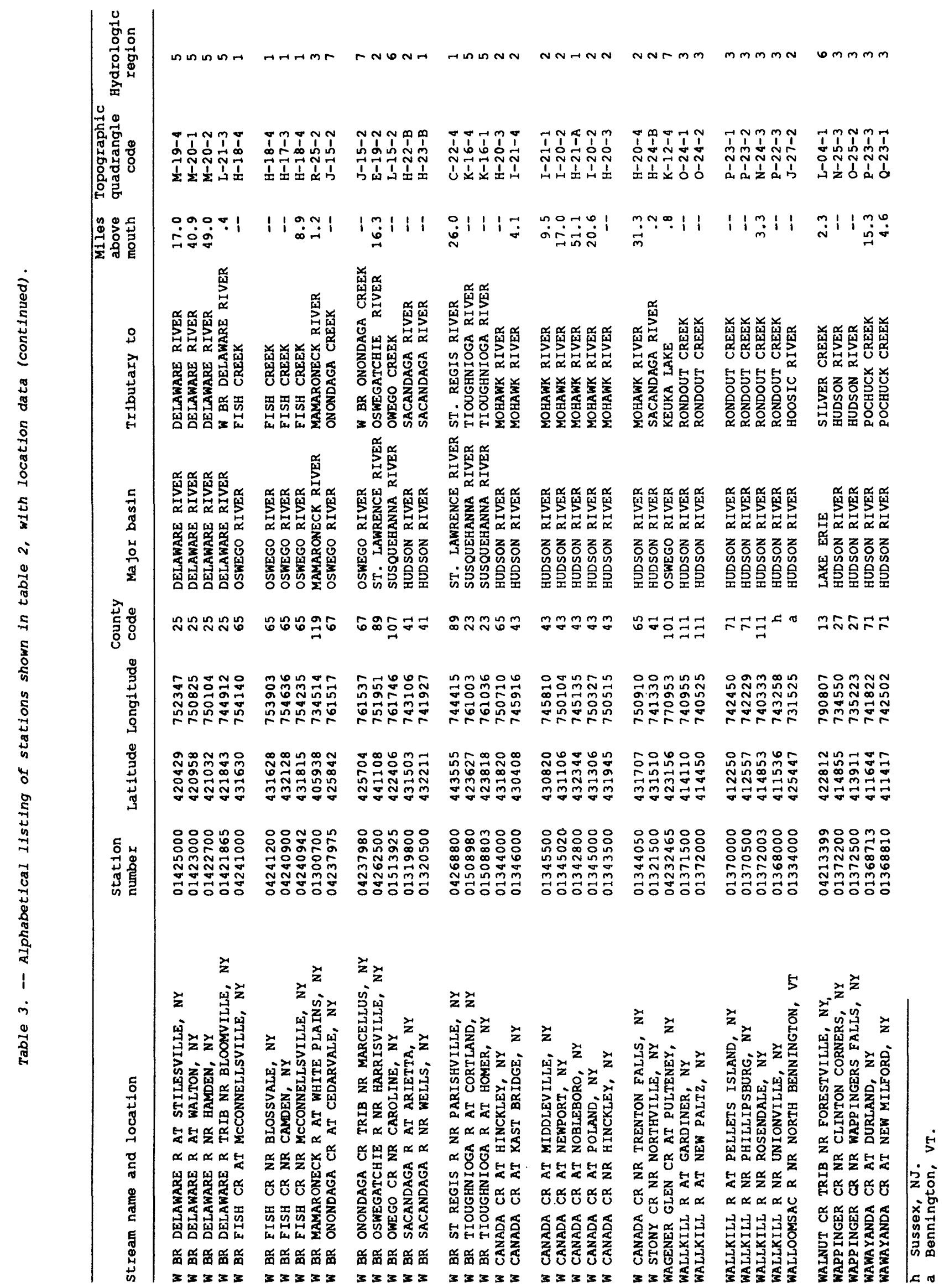




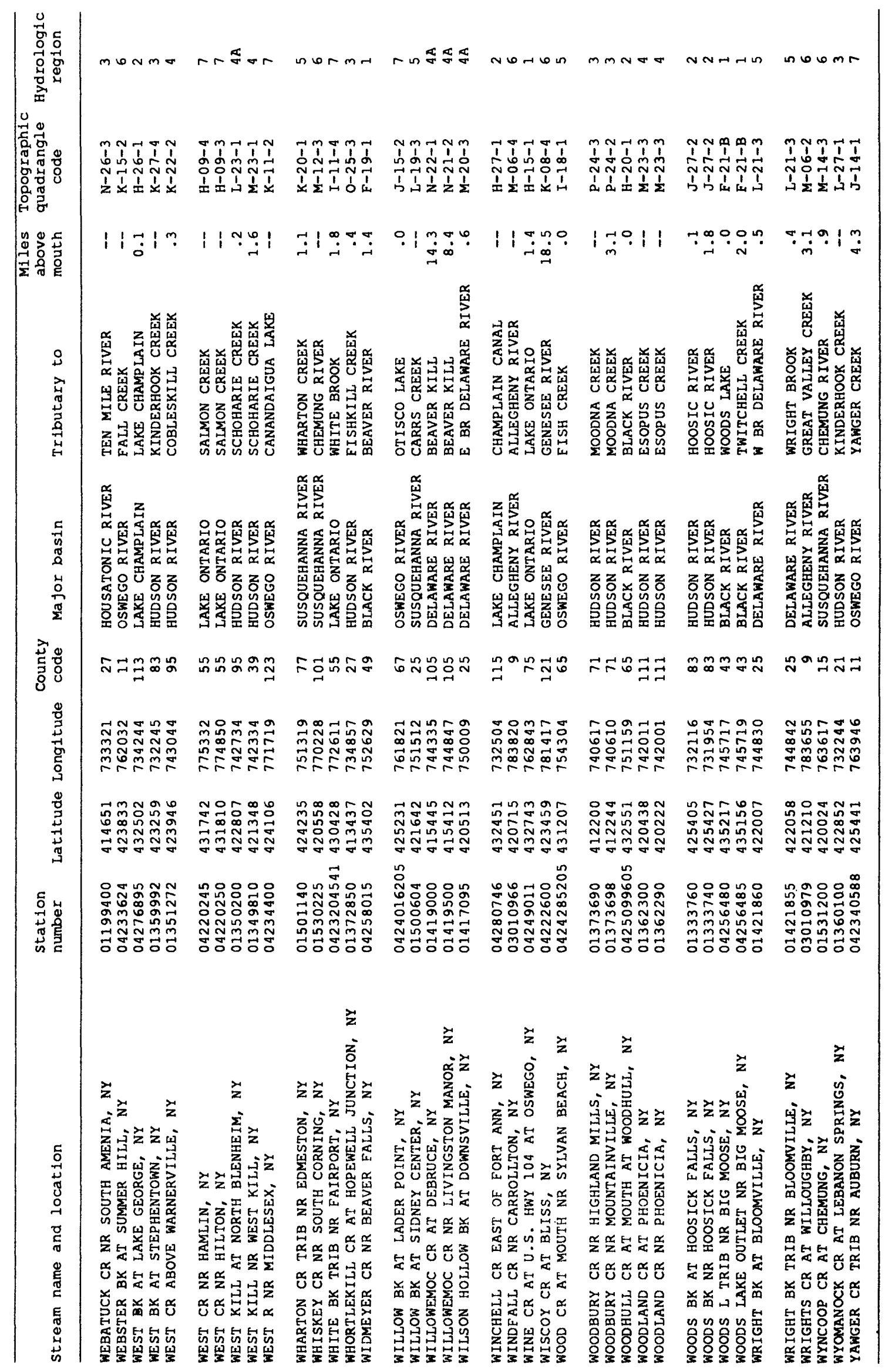

